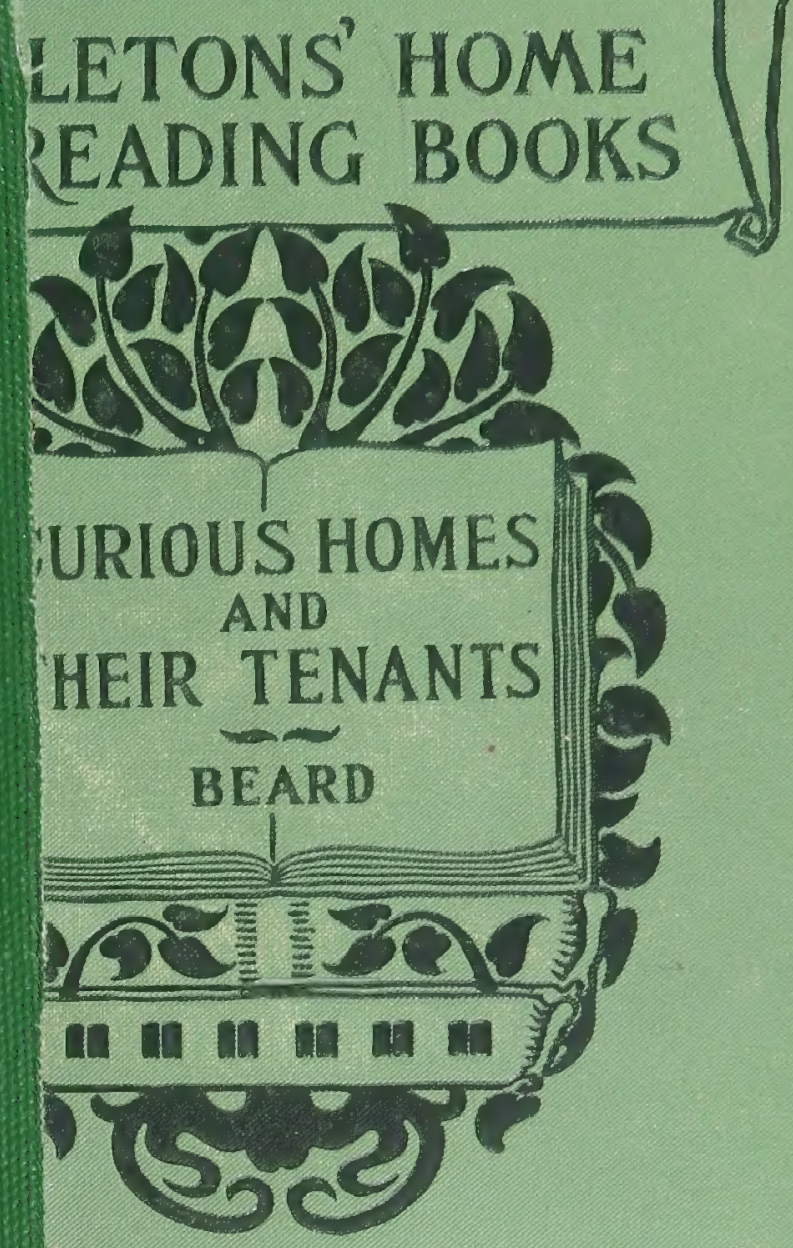




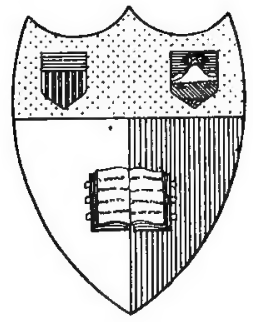

\section{Aixu 糸ark \\ State Çallege of Anrirulture}

At Curnell Hnuersity

3)thata, 소. 照.

\section{Tifhrary}




\section{QL 756.837 \\ Cornell University Library}

Curious homes and their tenants,

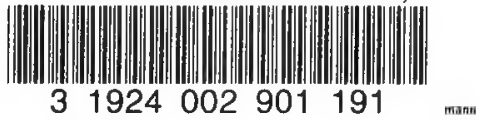




\section{Cornell University Library}

The original of this book is in the Cornell University Library.

There are no known copyright restrictions in the United States on the use of the text.

http://www.archive.org/details/cu31924002901191 

APPLETONS' HOME READING BOOKS

\section{CURIOUS HOMES \\ AND THEIR TENANTS}

BY

JAMES CARTER BEARD

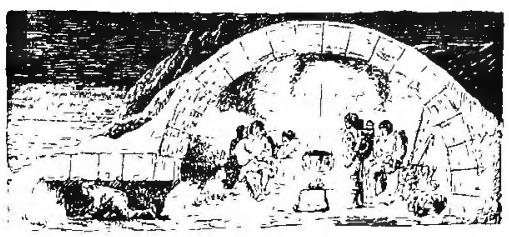

NEW YORK

D. APPLETON AND COMPANY

I 898

it 4 
Coptright, 1897,

BY D. APPLETON AND COMPANY. 


\section{INTRODUCTION TO THE HOME READING BOOK SERIES BY THE EDITOR.}

The new education takes 'two important directions-one of these is toward original observation, requiring the pupil to test and verify what is taught him at school by his own experiments. The information that he learns from books or hears from his teacher's lips must be assimilated by incorporating it with his own experience.

The other direction pointed out by the new education is systematic home reading. It forms a part of school extension of all kinds. The so-called "University Extension" that originated at Cambridge and Oxford has as its chief feature the aid of home reading by lectures and round-table discussions, led or conducted by experts who also lay out the course of reading. The Chautauquan movement in this country prescribes a series of excellent books and furnishes for a goodly number of its readers annual courses of lectures. The teachers' reading circles that exist in many States prescribe the books to be read, and publish some analysis, commentary, or catechism to aid the members.

Home reading, it seems, furnishes the essential basis of this great movement to extend education 
vi CURIOUS HOMES AND THEIR TENANTS.

beyond the school and to make self-culture a habit of life.

Looking more carefully at the difference between the two directions of the new education we can see what each accomplishes. There is first an effort to train the original powers of the individual and make him self-active, quick at observation, and free in his thinking. Next, the new education endeavors, by the reading of books and the study of the wisdom of the race, to make the child or youth a participator in the results of experience of all mankind.

These two movements may be made antagonistic by poor teaching. The book knowledge, containing as it does the precious lesson of human experience, may be so taught as to bring with it only dead rules of conduct, only dead scraps of information, and no stimulant to original thinking. Its contents may be memorized without being understood. On the other hand, the self-activity of the child may be stimulated at the expense of his social well-being-his originality may be cultivated at the expense of his rationality. If he is taught persistently to have his own way, to trust only his own senses, to eling to his own opinions heedless of the experience of his fellows, he is preparing for an unsuccessful, misanthropic career, and is likely enough to end his life in a madhouse.

It is admitted that a too exclusive study of the knowledge found in books, the knowledge which is aggregated from the experience and thought of other people, may result in loading the mind of the pupil with material which he can not use to advantage. 
Some minds are so full of lumber that there is no space left to set up a workshop. The necessity of uniting both of these directions of intellectual activity in the schools is therefore obvious, but we must not, in this place, fall into the error of supposing that it is the oral instruction in school and the personal influence of the teacher alone that excites the pupil to activity. Book instruction is not always dry and theoretical. The very persons who declaim against the book, and praise in such strong terms the self-activity of the pupil and original research, are mostly persons who have received their practical impulse from reading the writings of educational reformers. Very few persons have received an impulse from personal contact with inspiring teachers compared with the number that have received an impulse from such books as Herbert Spencer's Treatise on Education, Rousseau's Emile, Pestalozzi's Leonard and Gertrude, Francis W. Parker's Talks about Teaching, G. Stanley Hall's Pedagogical Seminary. Think in this connection, too, of the impulse to observation in natural science produced by such books as those of Hugh Miller, Faraday, Tyndall, Huxley, Agassiz, and Darwin.

The new scientific book is different from the old. The old style book of science gave dead results where the new one gives not only the results, but a minute account of the method employed in reaching those results. An insight into the method employed in discovery trains the reader into a naturalist, an historian, a sociologist. The books of the writers above named have done more to stimulate original research on the 
viii CURIOUS HOMES AND THEIR TENANTS.

part of their readers than all other influences combined.

It is therefore much more a matter of importance to get the right kind of book than to get a living teacher. The book which teaches results, and at the same time gives in an intelligible manner the steps of discovery and the methods employed, is a book which will stimulate the student to repeat the experiments described and get beyond these into fields of original research himself. Every one remembers the published lectures of Faraday on chemistry, which exercised a wide influence in changing the style of books on natural science, causing them to deal with method more than results, and thus to train the reader's power of conducting original research. Robinson Crusoe for nearly two hundred years has stimulated adventure and prompted young men to resort to the border lands of civilization. A library of home reading should contain books that stimulate to self-activity and arouse the spirit of inquiry. The books shonld treat of methods of discovery and evolution. All nature is unified by the discovery of the law of evolution. Each and every being in the world is now explained by the process of development to which it belongs. Every fact now throws light on all the others by illustrating the process of growth in which each has its end and aim.

The Home Reading Books are to be clussed as follows:

First Division. Natural history, including popular scientific treatises on plants and animals, and also de- 
scriptions of geographical localities. The branch of study in the district school course which corresponds to this is geography. Travels and sojourns in distant lands; special writings which treat of this or that animal or plant, or family of animals or plants; anything that relates to organic nature or to nieteorology, or descriptive astronomy may be placed in this class.

Second Division. Whatever relates to physics or natural philosophy, to the statics or dynamics of air or water or light or electricity, or to the properties of matter; whatever relates to chemistry, either organic or inorganic-books on these subjects belong to the class that relates to what is inorganic. Even the socalled organic chemistry relates to the analysis of organic bodies into their inorganic compounds.

Third Division. History and biography and ethnology. Books relating to the lives of individuals, and especially to the social life of the nation, and to the collisions of nations in war, as well as to the aid that one gives to another through commerce in times of peace; books on ethnology relating to the manners and customs of savage or civilized peoples; books on the primitive manners and customs which belong to the earliest human beings-books on these subjects belong to the third class, relating particularly to the human will, not merely the individual will but the social will, the will of the tribe or nation; and to this third class belong also books on ethics and morals, and on forms of government and laws, and what is included under the term civies or the duties of citizenship. 
Fourth Division. The fourth class of books includes more especially literature and works that make known the beautiful in such departments as sculpture, painting, architecture and music. Literature and art show human nature in the form of feelings, emotions, and aspirations, and they show how these feelings lead over to deeds and to clear thoughts. This department of books is perhaps more important than any other in our home reading, inasmuch as it teaches a knowledge of human nature and enables us to understand the motives that lead our fellow-men to action.

To each book is added an analysis in order to aid the reader in separating the essential points from the unessential, and give each its proper share of attention.

$$
\text { W. T. HARris. }
$$

Wasmingron, D. C., November 16, 1896. 


\section{PREFACE.}

No attempt, it seems almost useless to say, can be made in this little book to do more than attract the attention of its readers to the subject of which it treats and awaken their interest in it. Anything that excites curiosity and leads to the study of the home life and what may perhaps be called human traits in the lower animals, must necessarily be of use both in supplying means of wholesome, never-failing entertainment for the intellectual faculties, engaging and broadening our sympathies, and also in suggesting the standpoint that must be taken in rightly estimating either the capabilities or the limitations of any member of the greater brotherhood that includes not mankind only, but every living creature.

As the life of an animal is more or less centered in the exercise of parental solicitude for its young, the most perfect exhibition of its power to adapt means to a desired end may in a like degree be measured by the character of the home it provides for them and the manner in which it ministers to their comfort and protection. Judged by this standard, it is instructive to note the parallelisms and contrasts between the efforts of man unaided by the cumula- 
tive knowledge called science and those of the lower animals in building their habitations, and to observe the almost invariably superior results obtained through the greater constructive ability of the latter. This comparison has not, so far as the author knows, been elsewhere suggested, although several works have been written upon the architecture of insects and other animals.

Zoölogy is a progressive science, and even in so small a volume as the present one a number of recent discoveries in natural history, not to be found elsewhere in similar works are noticed. There is, indeed, more to be told than many rolumes could contain, and still more to learn than has yet been recorded in regard to the house-building and housekeeping of the children of Nature; and the author is not without hope that even the incomplete and unambitious sketches here given may incite some active young brain to busy itself with the subject. Children are among the best observers in the world. Their keen eyes and the direct and sympathetic deductions they make from what they see sometimes solve problems that puzzle their elders. No preparation or special apparatus is necessary to study the manners and coustoms of tiny tribes of which, though they fill our fields and forests and are always with us, we really know so little. Nothing but the leisure which attends so few of us older folks, and of interest in the work and love for it, which, I fear, still fewer possess, is required to make perhaps important discoveries, correct serious errors, or confirm observations already 
made in the field for investigation to be found in comparing the homes and habits of birds and beasts with those of human beings.

A novel feature in the present volume is the number of engravings it contains which are unnoticed in the letterpress. The purpose of their introduction is not alone to render the book more attractive, but, if possible, to extend its use beyond its text. The intention is that these additional drawings, the subject of each of which has been carefully selected on account of some special feature of interest it possesses, shall be instrumental in introducing the pupil into new and delightful fields of research. It is suggested, as an exercise of considerable value and utility, that the young student shall be required to embody the results of his investigations in written or oral accounts of the subjects illustrated, giving in every case special attention to details rather than generalizations, and to the habits and manner of life of the creature described rather than the place it occupies in the more or less artificial systems of naturalists.

J. Carter Beard.

July, 189\%. 



\section{TABLE OF CONTENTS.}

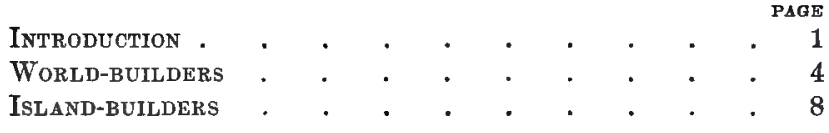

\section{HOMES IN THE EAR'TH.}

CAte-DWeliers

BtRds that BUILD EDIBLE NESTS . . . . . . 18

Moles . . . . . . . . . . . . 21

AN OBJECT OF SUPERSTITION . . . 27

A QUEER-LOOKING GROUND HOG . . . . . . 29

DOGS THAT ARE NOT DOGS . . 32

Bank bURrowers . . . . 36

A little quadruped that lays eggs . $\quad . \quad 39$

A PORCUPINE ANT-EA'TER. . . . . 41

JUMPING MICE . . . . . . 43

A FELLOW WITH POCKETS IN HIS CHEEKS . . . 47

DIAMOND BIRDS AND THEIR NESTS . . . 50

A BIRD BURROWER . . . . . . . . . 53

A TURRET-BUILDING SPIDER . . . . . . . 56

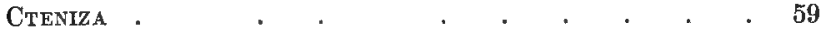

Bees and wasps as miners . . . . . . 62

ANTS AND THEIR HOMES.

Senses of AN'TS . . . . . . . . . . 68

How ANTS AND OTHER ANIMATS WORK . . . . . 71

ANTS АT HOME. . . . . . . . . . 74 
xVi CURIULS HOMES AND THEIR TENANTS.

Aaricultural ants

\section{IIOMES IN THE ROCKS.}

Human cliff-dwellers .

IIOMES IN THE TREES.

Tree houses in New Guinea 101

A strange animal.

Animalis that sleep throvgh the wiNter.

The feathered parion and his home . . . 134

Stealing a home. . . . . 138

WALLED IN . . . . . . . 140

THE WOOD-EATER . . . . . 144

Butterfly house. . . . . . . . . . 147 WASPS'NESTS . . . . . . . . . . 149

HOMES IN THE GRASS.

Human Nest-builders

\section{HOMES IN THE SNOW.}

Homes of tile Fsimo, white bear, aNd seal. 


\section{HOMES IN THIS WATER.}

HUMAN LAKE-DWELLIERS .

FOUR-FOOTED LAKE-DWELLERS. $\quad . \quad \cdot \quad \cdot 177$

A FLOATING NEST . . . . . . . . 181

WEB-SPINNING FISH AND NEST. . . . . 185

A QuARRELSONE LITTLE NEST-BUILdER . . . . . 187

A DOME UNDER WATER . . . . . . . . . . $\quad$. 189

Tube DWellings . . . . . . . . . 193

SEA SHELLS THAT BUILD NESTS LIKE THOSE OF BIRDS . . 196

HEAD-FOOTED NEST-BUILdERS . . . . . . . 200

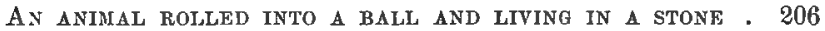

A NEST in a WATERfall . . . . . . . . 210

PORTABLE FOUSES.

Turcoman's portable villages . . . . . . . 215

The portable house of the hermit crab. • . . 219

\section{MISCELLANEOUS.}

A Waru house . . . . . . . . . 223

A house that wears a hat .

DWELLING IN SKELETONS OF WHALES . . . . 232

A HOME IN A HORN. . . . . . . . . 234

A CITY OF BLRDS . . . . . . . . . 236

Feathered gardeners . . . . . . . 242

The fun-loving Kagu . . . . . . . 246

THE SHADOW BIRDS. . . . . . . 249

Spiders AND COBWEBS . . . 252

DEATH IN A ROSE. . . . . 258

INSECT HOME-BUILDERS . . . . . . . . . 261 



\section{ANALYSIS OF CURIOUS HOMES AND THEIR TENANTS.}

AN analysis of a volume like the present, which is but a slight sketch of the work called for by the subject, and not in any sense a systematic treatise-it would defeat the author's purpose to make it so-must necessarily be very general in character, and rather devoted to suggestions with regard to the further pursuit of the themes started than to any formal epitome of its contents. The book is divided into a number of sections, under each of which is grouped together a description of the habitations of men and animals belonging to it, so that their homes can readily be compared and conclusions reached with regard to the relative excellence or imperfection of each in its own particular class.

In the introduction, the ancient races which inhabited America before the advent of the red man upon the continent are described as having built better homes, shown a greater excellence in manufactures of various kinds, and a much greater advance in social order than the native American Indians ever did; and all this notwithstanding the fact that these ancient races were nothing more than insects. Let the pupil read up on the aboriginal tribes of America and upon social insect communities, and take note of the differences in the manner of living and of the habitations of the one and the other, and also of analogies that certainly exist between them. Let him, as far as he xix 
can, reason out the causes of the similarity and the dissimilarity in the domestic economy of the savage and of the ant, wasp, or bee.

A brief description of the humble forms of life instrumental in building the great common homes of all land animals, including man, of course follows. The interdependence of natural history and geology here suggested in the formation of chalk and limestone and of coral reefs forms a most interesting subject for study and investigation.

Burrows, rude as the dens of wild beasts, and far inferior to the elaborate underground homes of many sorts of birds, beasts. and insects, seem to have been the first habitations of men. Certain tribes of savages and of the dwellers in the frigid zone remain burrowers to the present day. But among animals a relatively greater proportion of lower mammals and of insects than of birds or men excavate homes in the earth, and the physical and mental peculiarities of the classes mentioned that lead to a preference for underground homes form in this case a proper subject for investigation.

In the section devoted to ants, these, which with the bees, with the single exception of the termites, constitute perhaps the most extraordinary of all the tribes of the insect world, are briefly considered and their wonderful intelligence and social order described. Ants have developed a communistic order, a socialistic form of society, that is not only perfect of its kind, but is possibly the only one that can be maintained among more or less intelligent beings. These little citizens are never governed by personal considerations; all their allegiance is given to the community of which they are members. No family relations closer than those they owe to the whole society, no interests dearer than those that bind them to the body corporate, can exist. The division of labor among the different parts of the community does not elevate some and depress 
others in the social scale. All are useful, all are equal, all are brothers and sisters-the offspring of what may be called the parental department. But no personal love or friendships exist among them; they care no more for each other, except as representing individual fractions of the community, than one part of a vegetable growth cares for another-the branch for the twig or the twig for the leaf. Like some tribes of Indians, they kill off without pity or remorse all helplessly aged or useless individuals; even their common mothers are, we are assured, sacrificed when too old to be of further use; and they ruthlessly expel from the community their non-working brothers and sisters who have grown to be perfect males and females, and, although the objects of the greatest solicitude and tenderest care up to the period of their expulsion, their welfare ceases from that moment to be of the slightest concern to any member of the community.

Lonked at as a citizen of a republic with peculiar laws and customs, the little communities of ants to be everywhere found become as interesting as strange tribes of men in distant countries; and as nothing prevents the student from personally investigating their manners and customs, it is quite possible that no book yet published can tell him what he may find out for himself.

As detailed a description as the limits of this little book allow has been given of the wonderful cliff-dwellings in the southwestern part of the United States, but many interesting questions with regard to the people who once lived in them have been necessarily passed without notice. The whole subject is intensely interesting, and has been treated at length in magazines and Government reports. It is within the bounds of possibility that some who read these words have visited these most interesting ruins, or may at some future day do so, and the author of the present volume will feel that he has accomplished a most useful work if he succeeds in awakening in any boy's or girl's 
mind a desire or purpose to find out for himself or herself all they can of these ruins, more interesting to Americans than any that can be seen in the Old World, and to penetrate, if possible, at some time in his or her life the mystery that surrounds them.

Homes in the trees form a subject that is practically inexhaustible, and scarcely needs any suggestion as to the line of study in following it out; though after the inevitable comparison that offers itself to our mind between the rude attempts of untaught savages at building homes in the trees and the skillful and workmanlike habitations constructed by many sorts of birds, the birdlike nests of many quadruped mammals excite our attention and curiosity, and lead us to inquire what other traits these furry nest-builders possess in common with feathered ones. The same lines of study may be pursued for homes in the grass.

Homes in the snow emphasize the fact that under similar circumstances men aud beasts may possess pretty much the same sort of homes-a fact that is further illustrated in homes in the water. The lines of study suggested under these two sections are, however, too obvious to require special directions, and too numerous to receive justice in the limited space here available.

The use of portable houses admits of a great number of instances not mentioned in the letterpress. These are to be found among the caddice worms, caterpillars, and other insects, as well as many more curious examples than those described in the text. Among the hermit crabs the pupil's line of investigation will naturally lie in this direction.

Among the homes classed as miscellaneous, in the last section, are those whose oddity, though the most striking, is by no means the chief element of interest; they illustrate the extreme adaptability of living creatures of many sorts, including mankind, in accommodating the most unpromising materials and situations to their need of some 
sort of habitation. It is of the utmost importance that the pupil be taught to reason out, as far as he can, in every case the causes of the form and character of each habitation as it comes in turn under consideration, for it is the ratiocinative and imaginative faculties rather than those of memory and method that this little book is intended to stimulate; not because these latter mental endowments are less indispensable and valuable than the former, but because the limits of the work do not admit of anything more. It is also to be remembered that the cultivation of memory and system are far more valuable when they follow than when they precede the interest awakened by appeals to the reason and imagination. 



\section{CURIOUS HOMES \\ AND THEIR TENANTS.}

INTRODUCTORY.

COMMUNAL DWELLINGS, AND THOSE WHO INHABIT THEM.

The Indians upon the eastern coast of North America, as the first European settlers found them, had, as we well know, no cities, no roads, and no buildings, unless the rude temporary shelter of bark wigwams can be so called. They had little more real government than a herd of beasts. They dressed in skins, because they could not weave cloth, and their arrows had heads of flint, because the red men of the forest did not know how to make them of metal. Their plow was the bough of a tree or a clamshell, and they had no horses, cows, or any domestic animals except their dogs. Of books or reading or writing they knew nothing. At the same time other tribes far in the Southwest lived in villages, tilled the land, made pottery and cloth, and were in every respect far more civilized. They are called Pueblo Indians, because they lived in pueblos, or villages consisting of single houses. One of these huge structures of mud or stone contained thousands of tenants, a town or city in a single house. 
But long before the Indian came to America the continent was inhabited by puny races that equaled and in some cases perhaps surpassed him in arts and manufactures, certainly in their architecture, and still more certainly in their laws and customs. Like the Pueblo Indians, they lived and still live-for they have not been extirpated, as the greater part of the Indians have-in communities occupying a single dwelling, each a nation by itself, and, unlike human societies, every member more interested and careful for the general welfare than for that of any individual. It is true such races are insects. They do not resemble human beings in outward shape, but there is more in common between these small, strangely formed creatures and ourselves than is generally supposed; and the fact that they have dereloped a social order in some respects at least far in advance of any that human beings have ever been able to establish, makes it worth our while to study their manners and customs; for it is not impossible that even from tribes of insignificant insects, which are generally viewed with disgust or contemptuous indifference, we may learn something useful.

Among human beings, although each family usually has a house to itself, it often happens, where there is comparatively little space and a large number of people living together, several families reside in one building. Indeed, in the more crowded districts of large cities more than one family live on the same floor, and there is often at least one separate family in each and every room. There are other reasons 
than want of space that make it necessary for a number of people to have a common home and live together under one roof; where there is danger to be feared from attacks by hostile tribes, or where mutual help or great economy of labor can be secured, as in the case of soldiers in their barracks, or workmen employed in some large factory, the same banding together of families is to be found.

This association of numbers of individuals into societies, much more closely bound together by ties of mutual interest than are any composed of human beings, is found to some extent among birds and mammals, but oftener and in far greater perfection among insects.

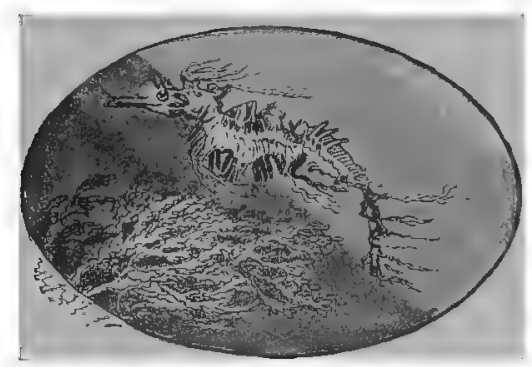

Australian sea-horse. 


\section{WORLD-BUILDERS.}

THE LEAST THE GREATEST.

There is an animal called amebe which is without doubt the strangest creature known. It looks like a speck or tiny drop of jelly; even when seen through a powerful microscope it still appears nothing more than a lifeless bit of slime; and yet it is a living, moving animal that pursues and captures and devours its prey, and seems to have a mind and will of its own, and to enjoy life as much as many creatures fully provided with parts and members. When, for instance, the amœba wants to take a walk, its lack of legs does not trouble it, for it simply pushes them out of its body, as nuany as it requires, makes them as long or as short as it chooses, and sets out merrily on its way. Do not think for a moment, however, that the Amøba uses its legs to walk on. No, this creature is mulike other animals in everything it does. Instead of crawling like a worm or snail, it flows, for you must not forget it is a sort of liquid animal, and is different from other living things in this, as in all else; the substance of its body runs into the parts it has thrown out, as water or ink flows and fills splashes down the lid of a desk or other slanting surface. How it can flow itself in this way along a level, or even up an inclined plane, as it does, is more than any one his yet been able to find out. 
When it has in this way run its entire contents into its false feet-or pseudopodia, as men of science call the splashes it sends forward-and collected its

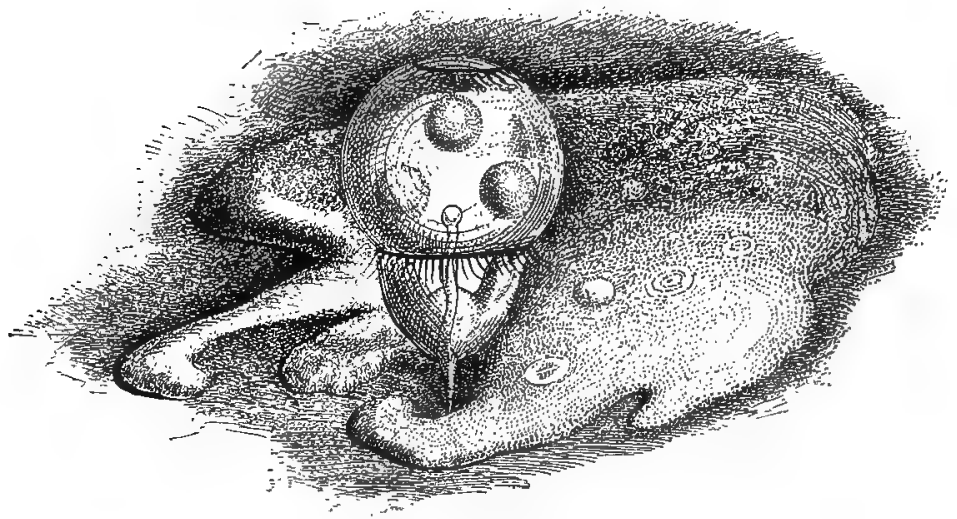

Amoba flowing over and devouring microscopic animal.

whole substance in the place taken by its advanced parts, it again pushes out pseudopodia, and in this way glides slowly along.

Perhaps the strangest part of the life story of this animal is the way it breaks itself into little bits, and from being one animal becomes many. When this remarkable change is about to happen, the amceba ceases to move, puts on a thick crust or covering, and turns into a number of little balls, each able to live by itself; presently the covering bursts, and each little ball becomes a perfect amoba; though sometimes they all conclude to grow together again and become one animal, in which case, whether or not the 
last animal is the same one that burst to pieces it would indeed be hard to say.

Sometimes, however, these curious little creatures build themselves habitations as light, fragile, and delicate as frost crystals. The species that do this live in sea water. Many of their homes are shaped like flasks ; some appear, when magnified, like the gem fruits that Aladdin found in the magic caverns; some look like tiny jewel beads, others grow in elegant spirals - in short, the variety of their forms and decorated surfaces seems inexhaustible. Thousands of living and fossil species have been distinguished by naturalists. Nothing relating to these bits of living jelly is quite so wonderful or important as the part they take in building up the earth.

Once upon a time, as old stories begin-though just how long ago no one can tell, for, if we are to believe geologists, countless centuries have passed since the vast ancient aceans contained a large per cent of lime and also unnumbered populations of shell-bearing amœbæ-all of these minute animals were for ages and ages constantly employed in building their pretty little dwellings from the lime they took from the water in which they lived. Billions of billions, vast numbers, too great for human conception, of generations followed each other in brief succession, their corruptible parts disappeared, and their shells falling in a never-ending shower upon the bottom of the ocean, in its shallower parts, built the islands and continents of a primitive world, in what geologists call the Cretaceous or Chalk period. It is 
said the shells fell to the bottom of the ocean in its shallower parts, because at the greater depths of the ocean the sea water through which they gradually sink to the distant ocean floor dissolves the delicate shells and gets back the lime of which it was robbed by the living animals before their empty houses can collect at the bottom; so that soundings at great sea depths show no trace of foraminifera, as these tiny housebuilders are called.

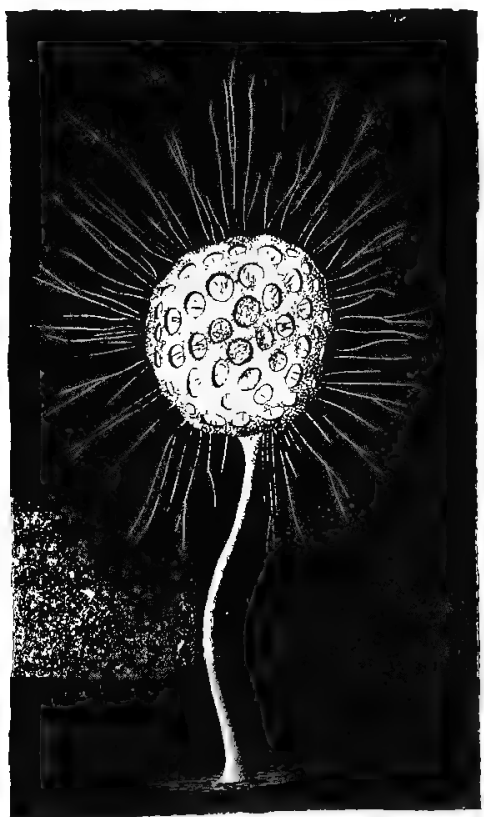

Latticed infusoria. 


\section{ISLAND-BUILDERS.}

WHERE THEY GROW.

There is a wonderful country under the sea-a country of hills and plains, of lofty mountains and deep valleys, of rocks and caves. Its widespreading meadows are covered with strange animal flowers

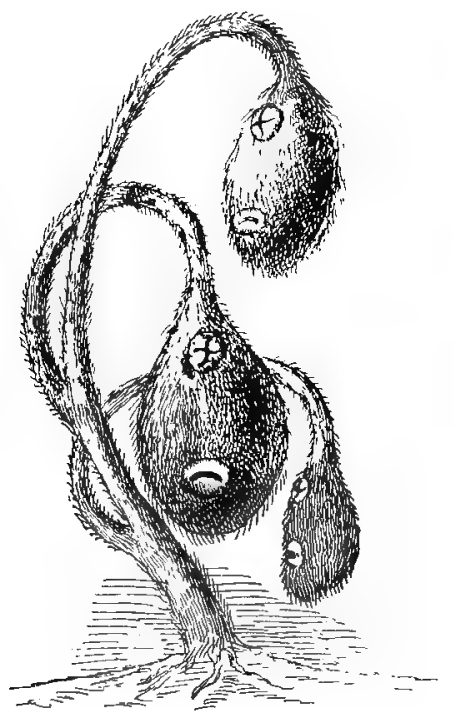

Sea squirts. that sway to and fro in search of living prey, and its forests consist of branching corals and seaweeds taller than the tallest trees. Tempests may rage fiercely above, but a deep, unbroken silence and tranquillity reign always in this under world; nor can the wildest tempest that wrecks the strongest vessels move the delicate tendrils of the sea plants in the depths below. Fragile creatures of untold loveliness, that fall to pieces almost at a touch, here spend their lives in quiet and security. The 
ocean depths, which for mankind are regions of breathlessness and death, are for myriads of animals the region of life and health.

The earth does not maintain nearly so many living creatures as swarm in countless multitudes beneath the

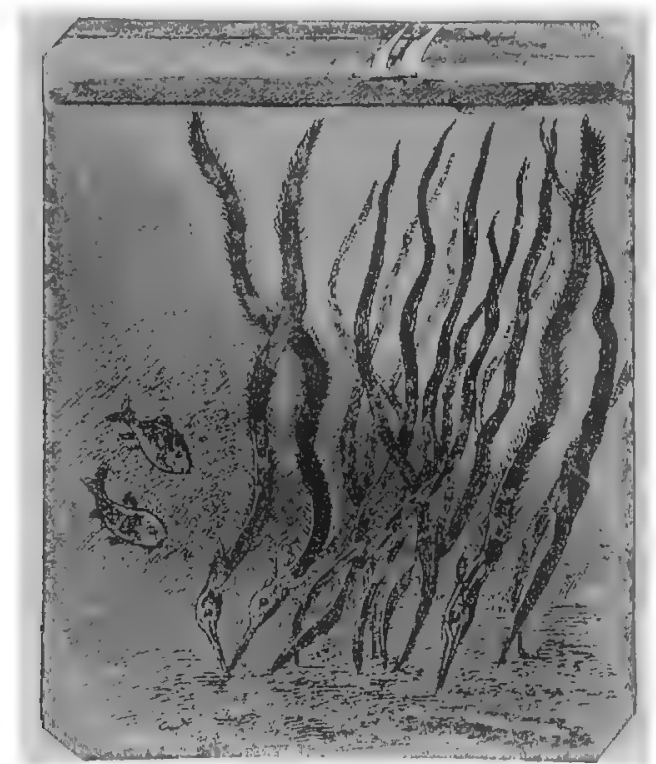

Grasstish.

waves of the ocean. Here grow the quaint-looking sea squirts; here the strange sea spiders pass their lives in the greatest depths of the ocean; here swim the fish which are to the world of waters what birds are to the upper world; the quaintest and most eccentric of creatures, as the sea horses, the grassfish, and 
others, and the most beautiful and brilliant, the chætodonts and the so-called dolphins, the coryphænoids; and here the rare and beautiful corals are silently builded into reefs and islands.

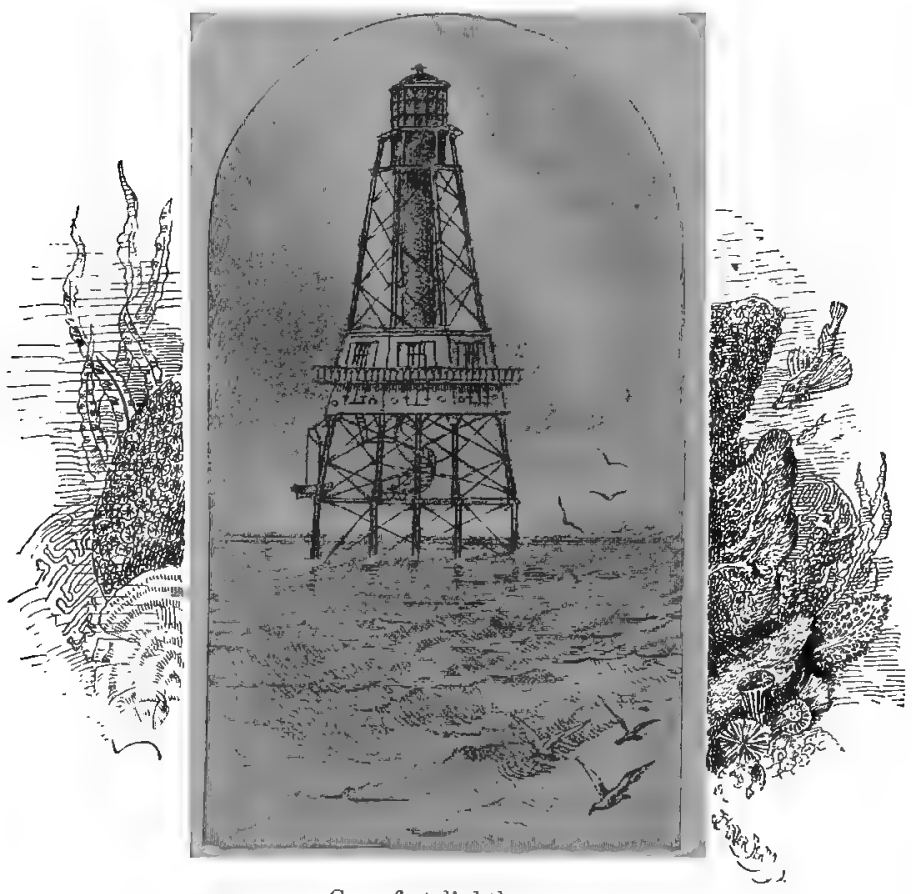

Carysfort lighthouse.

If it should ever he your good fortune to go to Florida and visit the Keys at the southern end of the State, you may see a coral plantation alive and growing. There is a famous ligbthouse, called Carysfort 
Light, off the coast here, from which such a sight can be had. Carysfort Light is built in the open sea, without a foot of land about it. It is an iron framework of columns, strengthened by a network of braces and girders, and the rooms in which the keeper lives are about halfway up to the light, out of reach of the waves, forty or fifty feet above the water. A balcony runs about these rooms, and as the lighthouse is built over one of the most beautiful and extensive fields of coral on this or any other coast, the view presented on looking from this balcony is more wonderful than can well be imagined by one who has not seen it.

The coral field spreads out around the lighthouse as far as the eye can reach, and so transparent is the water that the ocean bottom can be seen as plainly as a garden lying beneath. The coral field is largely made up of what are called leaf corals, with great flat branches that grow one above another. Myriads of fish play among these spreading branches, chasing each other singly and in companies, darting about, winding in and out the corals as if in a game of hideand-go-seek. Most of them are of very brilliant colors, some of them of the most intense azure blue, others bright blue and glossy black ; others, again, black banded with gold; and still others of a clear canary-yellow beneath and a complementary rich purple above. Now and then a large fish-a shark, perhaps-passes by, and all the small fry scatter among the corals and are seen no more until their enemy is out of sight. Besides the leaf corals there are many more still more beautiful to be seen. Some are shaped like huge vases; others 
branch out as do the horns of a stag, or still more delicately into fine tendrils like a plant; and there are great numbers of gorgeously col-

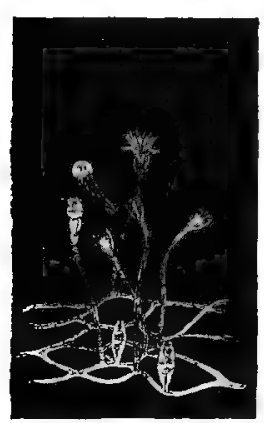

Hydroids. ored sea fans. The sea fans form the shrubbery of this ocean garden ; they stand on the sea bottom on a sort of root, and, unlike the leaf and branching corals, which are rigid and motionless, they rise and fall lightly in the water and wave in the gentle undercurrents as if stirred by a breeze. They are of many colors, and mingled, as they are, with a sort of vegetable coral called coralline, and with the bright purple, carmine red, and orange-colored sponges of the Florida coast, you may well realize in looking at them how surpassingly beautiful are the flower gardens of the sea.

\section{CORAL POLYPS.}

HOW THEY GROW.

It is to give some idea of the appearance of a field of growing coral in its natural condition that the foregoing description has been written; but the individual coral animal, and the home it makes for itself, in so doing contributing its mite to the building up of 
islands and continents, the abode of the human race, is no less worthy of attention. The two tiny creatures - one almost microscopic in size, the foraminifera,

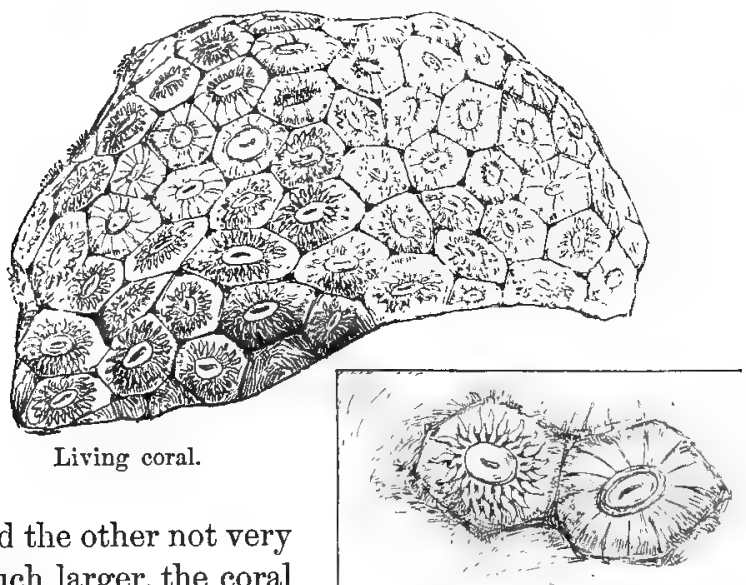

much larger, the coral polyps-are the most important of all the

home makers among the lower animals, for without them man nor beast could scarce have found rest for the soles of their feet.

The coral animal begins life as a free-swimming, little worm-like creature, called a planula. It is covered with cilia or bristles, which by their continual motion act as paddles or oars, and enable the planula to progress through the water. After a time the creature settles down, and, fastening itself to a rock or a piece of dead coral by its larger end, begins to live like a vegetable rather than an animal, having lost the power of 
locomotion, and being fixed for life to the spot to which it is attached. It now alters its shape, and develops eight tiny buttonlike projections about the fore end that contains the mouth, and soon grows a row of fringed feelers or tentacles like petals, becoming so much like a blossom in appearance that up to a comparatively recent time they were supposed to be the flowers of some sea plant. From the stalk of this little anemone-like creature buds put forth, soon showing a mouth like that of their parent, and around these grow tentacles, so that the solitary little polyps becomes a cluster of coral animals. Besides these two modes of increasing and multiplying, corals have a third and more remarkable one, in which, however contradictory it may seem, the sum total of the coral colony is increased and multiplied by being divided, the animals splitting themselves up, and each and every portion becoming a perfect animal.

One of the main differences between a coral polyp and an anemone is, that the former has the power of continually depositing at its base little particles of carbonate of lime, and of thus building a base or support for its house. The polyp does not do this consciously or purposely, or has it any more will in the matter than we do in growing our bones; but, to use a fashionable phrase of the day, "he is the instrument of a great work." Year by year his skeletons accumulate, all cemented together in one mass, until after countless centuries a great reef is formed and a new land begun, which, but for the part he took in making it, would never have existed. 


\title{
HUMAN CAVE-DWELLERS.
}

\author{
HOW THEY LIVED.
}

There is an old story of an Indian who, being asked how he could endure severe weather without clothing, replied that white men exposed their uncovered faces to the cold without discomfort, and that an Indian's body is all face. The primitive man has little use for furnace-heated rooms from which all fresh air is excluded, or for garments to bind and constrain the free movement of body or limb. His house is often as slight and temporary as the nests of some of the birds or the lairs of beasts, and however much we may despise him for going unclothed and living in rude huts, it can not be better to have to depend upon elaborate and expensive dwellings and garments, and all sorts of artificial protection from the climate in which we live, to make us comfortable.

The simplest huts constructed by savages are invisible, and confer the same property upon those who inhabit them. It sometimes happens that all the men of a tribe of native Australians leave their women and children and go off on an expedition, perhaps to attack some neighboring tribe. "These," says a writer on the subject, "knowing they might be pounced upon by enemies who would take advantage of the absence of their defenders, retire into the recesses of the woods, where they build the oddest 
houses imaginable, half burrows scraped among the roots of trees and half huts made of bark and decayed wood."

These habitations so much resemble the natural formation of the ground about them that no one but a native can discover them--even the more permanent dwelling places of these people always occupying some out-of-the-way place where the surroundings harmonize as closely as possible with the shelter that, rude as it is, answers all their needs. Very many centuries ago-just how long no one can now pretend to say-all western Europe seems to have been inhabited by races of savage men who lived in caves, and are consequently called cave-dwellers. They were very far behind the cliff-dwellers in civilization. They could neither spin nor weave, make baskets or pottery. They do not seem to have altered the shape or proportion of the caverns in which they dwelt to make them more comfortable, or even to have built chimneys or made openings for the escape of the smoke of their fires. The most we can credit them with is a rough lean-to, as it is called, formed perhaps of logs and bark propped up against the side of a rock or bank.

These ancient people are believed to have dressed in the skins of beasts, and to have employed such rude skill as they possessed in the formation of stone spear and arrow heads, hatchets, flint knives, and the like. Indeed, as far as ascertained, they appear to have lived much as the native American Indians in the northeastern part of the continent, by hunting. 
Many of the beasts they hunted are no longer found upon the earth. The great hairy mammoth and early elephant, much larger than any now existing, together with the hippopotamus and the rhinoceros, roamed through the valleys and along the rivers, and enormous bears and tigers preyed upon them. These early savages were cannibals, but besides the chase lived principally upon shellfish. Great heaps of shells of the mollusks they lived upon are yet found, as well as the charred bones of the beasts they ate.

The rudest form of habitation next to a natural cave is a burrow, and the first advance toward civilization on the part of the cave-dwellers seems to have been the construction of underground habitations. Some of these still exist in England, Scotland, and other parts of Europe. Many are little better than mere holes in the earth; such are the dugouts made in the sides of hills by emigrants to Kansas, New Mexico, and California, but most of these are only designed for temporary use, and are abandoned for more comfortable cabins as soon as such can be built. The natives of cold countries often construct subterranean or partly subterranean dwellings, seeking refuge from the intense cold winds that prevail on the surface; and the natives of tropical lands have frequently done the same thing to escape the intense heat aboveground. 


\section{BIRDS THAT MAKE EDIBLE NESTS.}

FEATHERED CAVE-DWELLERS.

Among the lower animals the most notable of cavedwellers are perhaps the swallows, and the species most worthy the name the two varieties of esculent swallow from whose nests the celebrated bird's-nest soup of the Chinese is made. The birds inhabit the Sunda Islands, Ceylon, Borneo, Java, etc. The nests are built against the sides of steep, cavernous cliffs, so that collecting them is an extremely perilous undertaking. They are attached to the face of the rocks much as are the mud-built habitations of the common swallow. These strange nests, however, are constructed in a manner that finds no parallel in the bird kingdom. A number of creatures other than spiders secrete a viscid fluid from which they form threads for the capture of prey or the building of nests. Among fish, the stickleback and the antennarias bind together the materials that form their nests with glutinous cords drawn from their bodies; but among birds the only instance of the kind known is the esculent swallow.

When about to lay the foundation of her future home, the glands under her tongue, which at this time are so distended as to form two large swellings, give out the sticky fluid of which her nest is composed. The bird presses her tongue, which answers to the 
spinnerets of the spider, against the rock that is to serve as a support, and then going back a few steps draws out a long, gummy thread, which dries and hardens very rapidly. This she forms into a sort of web by turning her head from side to side, making the undulating lines that appear in these remarkable structures. The process is continued until the nest has attained the required shape and dimensions. When completed it is about the size and shape of a quarter of an eggshell of the domestic fowl, divided along its entire length. There are two sorts, constructed by two species of the bird. That of the true esculent swallow called Salangene is as white and clean and translucent as porcelain, and is very highly valued; that of the other species, called Kusappi, is brown, and mixed with feathers, grass, and other foreign substances, and is but little esteemed. Mr. H. Pryer gives the following account of the breeding places and nests of the esculent swallow in northern Borneo:

"After a rest I ascended the cliff about four hundred feet; the ascent is quite perpendicular; in many places ladders are erected, and in others the waterworn surface of the limestone gives a foothold. At this point I found myself at the mouth of a cave called the White Cave ; the entrance is about forty feet high by sixty feet wide, and descends very steeply, widening out to a great size, and having a perpendicular unexplored abyss at its farthest point. This cave is used by the nest gatherers as their dwelling place, and at the entrance are their platforms of sticks, one of 
which was placed at my disposal by the head man ; it is also the cave at which the great body of swifts (esculent swallows) enter. At a quarter to 6 P. M. the swifts began to enter the White Cave. A few had been flying in and out all day long, but now they began to pour in, at first in tens and then in hundreds. They continued flying in until after midnight, as I could still see them flashing by over my head when I went to sleep. As long as it remained light I found it impossible to catch any with my butterfly net, but after dark it was only necessary to wave the net in the air to secure as many as I wanted. Nevertheless, they must possess wonderful powers of sight to fly about in the dark in the most obscure recesses of the cave, and to return unerringly to their nests, often built in places where no light ever penetrates. Arising before daylight I witnessed a reversal of the proceedings of the previous night, the swifts now going out of the White Cave.

"In this cave I saw the nest gatherers at work getting in their crop. A thin rattan ladder was fixed at the end of a long pole and wedged against the rock. Two men were on the ladder. One carried a long four-pronged spear, a lighted candle being fixed to it a few inches below the prongs. By the aid of this light a suitable nest is found and transfixed with the prongs; a slight twist detaches the nest unbroken from the rock; the spear is then withdrawn until its head is within the reach of the second man, who takes the nest off the prongs and places it in a pouch carried at his waist. The nests of best quality 
are bound in packages with strips of rattan, the inferior being simply strung together. The best packages generally weigh one catty (one and a third pounds), averaging forty nests, and are sold at nine dollars each, the annual value of the nests gatlered being about twenty-five thousand dollars. These caves have been worked for seven generations without any diminution in the quantity. Three crops are taken during the year."

\section{THE MOLE.}

HOW HE WORKS.

Air, earth, and water, which in ancient times were called the three elements, each have their proper inhabitants. Of these the air offers the least resistance to progress through it, and the least support to bodies entirely surrounded by it. In consequence of this, birds are the swiftest of animals, but they are obliged at intervals to alight and rest upon something more substantial than the atmosphere through which they fly. Next to the birds, fish swimming in the water move forward with the greatest rapidity, nor do they need any more material support than the fluid in which they live. Men and beasts upon the surface of the ground, and thus not living entirely surrounded by any one element, are slower than birds or fish, but can make more rapid progress than animals that live entirely in the earth, as do moles, mole rats, echidnas, 
etc., though these underground creatures are able to burrow their way through the soil with greater rapidity than may be imagined. Indeed, so swift is the progress through the soil of some species of the mole family, that, placed upon the ground, they sink into it as if it were quicksand, and make such rapid progress that the most expert spadesman can not catch them.

There are, indeed, many animals that dig lairs and dens and nests underground in which they rest and bring up their little ones; but the mole, although he has the most curiously planned and carefully constructed subterranean dwelling place of them all, does not confine himself to it, but goes rambling off in any direction he chooses through the solid earth, almost as a fish swims in water. Perhaps he sets out to call upon a friend, or to hunt for the earthworms that are his staff of life, but, at any rate, by the exercise of some sense or faculty of which we human creatures know nothing, he finds less difficulty in making his way to any given locality and back again to his home than we sometimes do with the aid of our eyes and broad daylight to help us.

Have you ever watched laborers digging a cellarhow hard they have to work to make any appreciable progress? Let us do a little sum in simple proportion-single rule of three it used to be called in the country school I attended. A mole is to a man as a molehill is to the work a mole could do if he were as big as a man ; or, mole : man : : molebill.; and the answer is a space excavated, measuring about twelve 
by twenty feet. In other words, if we had tame moles of the average bulk and stature of human beings, we could set one to work and he would dig a cellar for us twelve feet deep and twenty feet square in the time it takes a mole to make his hill. But I doubt if it would pay very well to keep him, even though he might do more work than a patent steam excavator. Of course, we could not expect to feed him on grubs and worms, which are his natural aliment in his present diminutive proportions. We would have to substitute boa constrictors twenty feet long, and, so fearful is his voracity, he would require at least twenty-five or more of these huge serpents every day. But as he is perhaps the very fiercest as well as the most ravenous of mammals, it would without doubt be impossible to tame him at all. With a few blows of his enormously powerful claws he could tear an elephant in pieces, and his insatiable lust of slaughter would lead him to kill every living thing he encountered. A mole like the lad in the fairy tale, who could not learn to shiver and shake, does not in the least know what fear is, and in his combats with other moles shows a fury and fiery energy that nothing can surpass. 


\section{THE HOME OF THE MOLE.}

HOW IT IS BUILT.

The home of the mole is very strangely contrived, and knowing as little as we do of his life underground is unaccountable. Under the top and center of the molehill, so deeply buried as to be on a level with the earth's surface, about the hill is a hollow like the inside of a globe. This spherical apartment is girt about with two circular tunnels: one, in the accompanying illustration, above the apartment; and the other is level with the ceiling. From this lower circular gallery ascend fire passages at equal distances apart to the upper one, and from this again descend three short passages opening into the ceiling of the central spherical apartment. In getting into this last-named chamber a mole has first to enter the lower circular passageway, ascend to the upper one-which, by the way, is much smaller than the lowerand then again descend before reaching his destination. There is, however, a lower passage that, leading directly from one of the larger highways or tunnels, descends in a curve, and then ascending opens into the floor of the central chamber. None of the main passages-there are seven or eight of them leading out in different directions from the lower central gallery-ever open upon it opposite one of the entrances into the upper gallery. 
The earth that forms the walls of these galleries is always firm, hard, and smooth, from the continual pressure of the mole's fur in passing through them, so that the severest rain, though the moisture penetrates

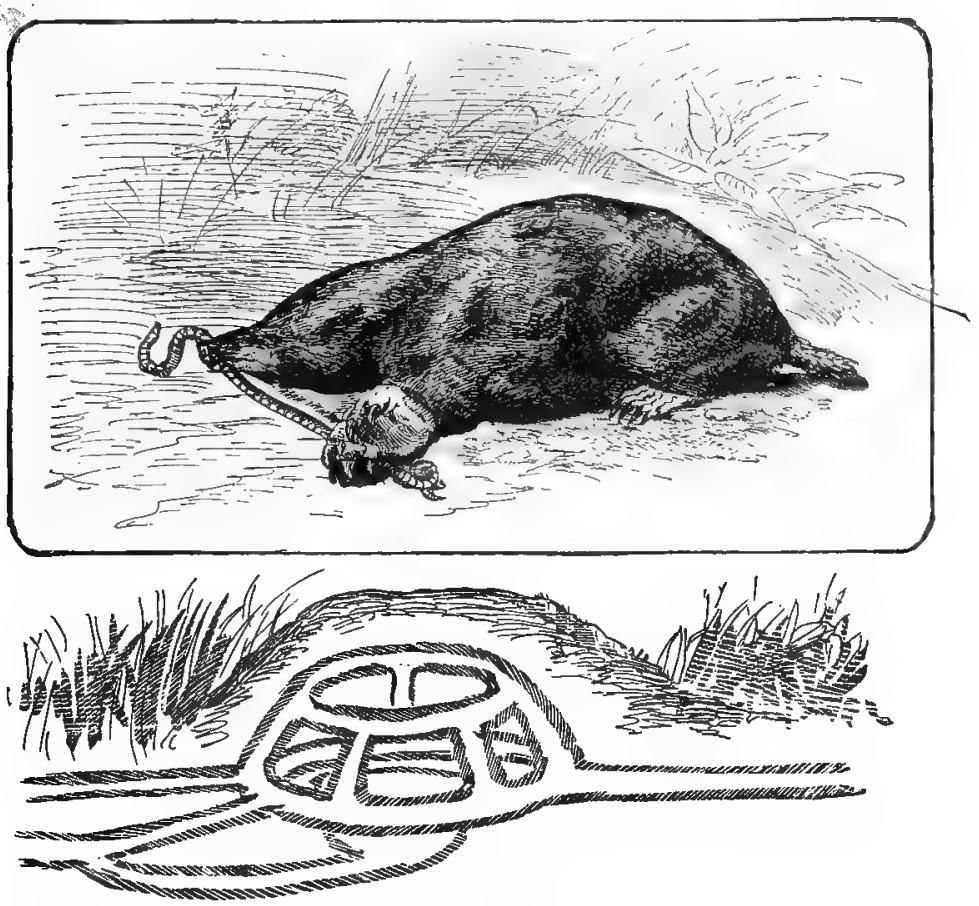

and permeates the whole molehill, will not cause them to break or cave in. As no known enemy can penetrate the passageways made by the mole-and if one could, the mole would in all probability prove more than a match for any animal small enough to do so, 
or, if worsted in the battle, might plunge into unknown depths of solid earth-the use of all this complicated arrangement of tunnel is extremely problematical, especially as the central chamber, it seems, is not nsed as a retreat or sleeping place or nursery. The mole usually sleeps about three hours, and is awake for the same length of time, without regard to day or night, but he sleeps in the passageways. The nursery is a large chamber excavated where several passages meet, so that, perhaps, if danger threatens, the mother mole and her little ones can the more easily escape in any direction along a ready-made tunnel.

There is a peculiarity about the fur of a mole that keeps it clean and glossy, no matter how much its wearer covers it with loose soil or luurrows in loam or clay. The hairs when they issue from the skin are very slender, thickening gradually as they extend, and then tapering off again and again, thickening throughout their entire length. This enables them to lie evenly in any direction, backward or forward, so that they always present a smooth, unbroken surface to the soil with which they come in contact. The mole, passing almost all its life in complete darkness, is popularly supposed to be without eyes ; in fact, they are so very minute and so entirely hidden in its fur, and probably possess such imperfect power of vision, that they are comparatively of small account in the animal's physical make-up or his economy of life. Though he has no more visilule ears than eyes, for external ears would soon become choked up with earth, he is amply provided with the means both of 
hearing and smelling-senses that in its peculiar situation are far more useful and important than sight.

\title{
AN OBJECT OF SUPERSTITION.
}

\author{
AN ANT-EATER IN ARMOR.
}

As feathers are a distinguishing mark of birds, and scales or plates of solid substance of reptiles and fishes, so hair is generally supposed to constitute the natural covering of mammals; but in the pango-

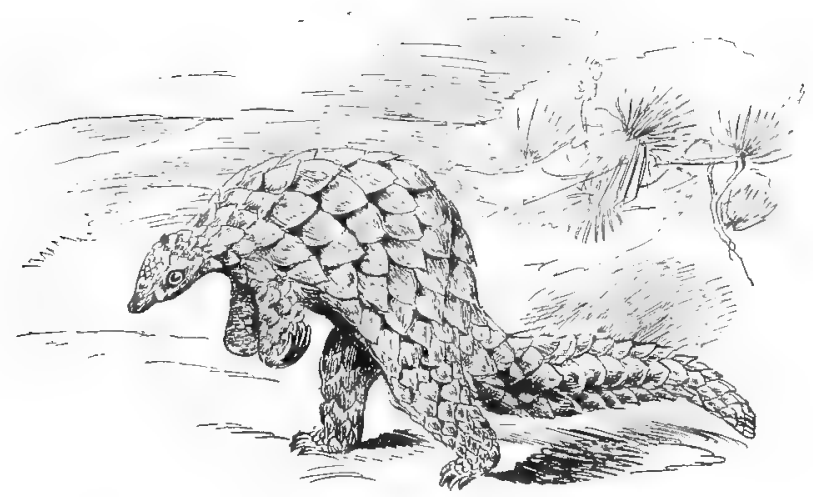

Scaly pangolin, ant-eater in armor.

lin we have an animal that at first sight must surely be mistaken for a reptile, not only because it resembles one in shape and general appearance, but because it is clothed with scales. The armadilloes, 
it is true, substitute a bony for a hairy covering, but even they-because some species are partly covered with hair, others have prominent ears, and all that possess tails show a marked division where these appendages join the body-do not suggest reptiles as forcibly as do the pangolins.

Like the aard-vark, a description of whose habits answers equally well for that of the pangolin, the species of strange animal here shown lives in South Africa. They range from two to nearly five feet long. The scales with which their body, limbs, and tails are covered are triangular, notched, bluntly angular, or rounded at the tip; they form a very complete suit of impenetrable scale armor, and must be of the greatest possible use to a toothless creature like the one described, which has no weapon with which to defend itself. When surprised outside its burrow the pangolin instantly rolls itself into the shape of a ball, taking particular care to tuck its small head, which is the only part unarmored, out of harm's way between its forelegs, wrapping its tail over it, and offers nothing but an array of sharp-edged scales projecting outward in every direction to the enemy.

The natives regard these animals with superstitious awe, which, however, does not prevent them from roasting the poor creatures alive as burnt offerings, in order that the powers above may cause the cattle of the worshiper to thrive and increase in number. Thus the oddity of the animals in appearance, by awakening superstition, has proved the cause of their destruction, for they have become very rare 
and difficult to find. In another case, that of the specter tarsius, the same cause has seemingly worked an opposite result, for the harmless but dreaded little specters owe their safety to the fact that the natives fear to approach them.

\section{A QUEER-LOOKING GROUND HOG.}

HOW HE LIVES AND WHAT HE LIVES ON.

Among burrowing animals none are more strangely constructed than the aard-vark or ground hog of southern Africa. At first, as he sits with rounded

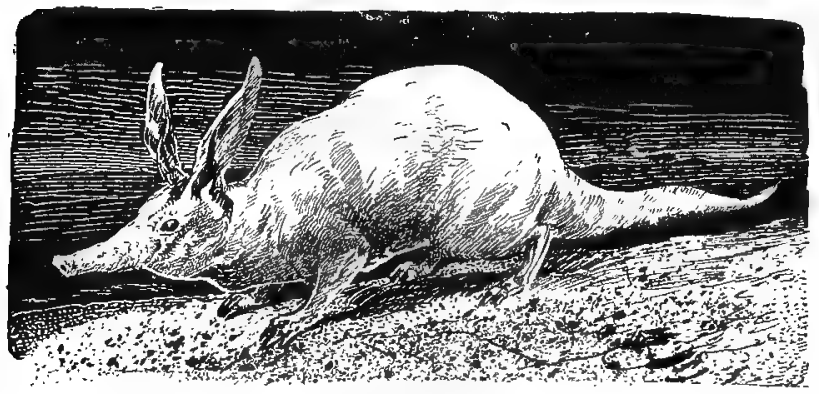

A queer-looking ground hog.

back, his long ears projecting over his shoulders, he Jooks like a gigantic hare, hut he has the broad, thick tail of a kangaroo; his long, conical head and small eyes remind one of a pig, but he has long, flattened claws, five on the hind limbs and four on the front, 
and he walks on the bottom of his feet like a bear. His light, pinkish skin, sparsely covered with bristles, again suggests the pig; but the mouth has only a small opening, and as a long, worm-shaped tongue, coated with a slimy secretion, makes its appearance, the creature is seen to belong to that strange group of mammals called ant-eaters.

Like all animals of this sort, he sleeps through the day and seeks his food at night. His burrows, though they do not penetrate far below the surface, are of considerable extent and dimensions; they are often two or more feet in diameter and three or four feet deep before they branch off into the large chamber which forms the sleeping apartment and nursery where the little ones are born and reared. Here the animal retreats in time of danger, and although one of the largest of burrowing animals, the aard-vark can work its way through the earth as rapidly as a mole, and when pursued ean dig so fast as to disappear beneath the surface before his pursuers can approach near enough to seize him, and can burrow through the ground more quickly than his enemies can shovel out the soil after him. Indeed, his claws and limbs, though not proportionately as strong as those of the mole, are most admirably adapted to his manner of life. The claws, which are long, strong, and hollowed out on their under surfaces, diminish in size from the inner to the outermost toe-a peculiar formation that, taken in connection with the moderate curve they make from root to point, without doubt greatly facilitates burrowing. Moreover, the strength of the aard-vark is sur- 
ficient to successfully resist the efforts of two or even three men to drag him from his hole.

It seems difficult to believe that so large an animal subsists entirely upon ants, and yet the fact can not be doubted. Indeed, nothing gives a more graphic idea of the innumerable hosts of ants and termites, or so-called white ants, in the country the aard-vark inhabits, than that, notwithstanding the enormous supply required by one of these animals even for a single meal, the ants do not decrease in number.

In certain sections of the country, not in the regions of the grassy downs or where it is dry and woody, but where the ground is too barren to sustain anything more succulent than the so-called sour grass (worthless for grazing purposes), gather the nest-building ants, and erect mounds that may well, at a little distance off, be taken for the huts of the natives, being for the most part from three to seven feet in height and of much the same shape as the dwelling places of the negroes. Like some enormous city of native Africans, these hutlike hills cover the plain as far as the eye can reach, a city of cities, for every mound contains within itself thousands upon thousands of inhabitants.

Here at night, fatal as some deadly pestilence, comes the silent aard-vark, breaks down the strongly built walls of the marvelous habitations that are capable of sustaining without injury the weight of a buffalo, and attacks the dismayed inhabitants. Forth stream the civic guard, the soldier caste, the defenders of the city; but how useless the powerful mandibles 
they brandish, or the devoted courage that leads them to face inevitable death in defense of their homes and kindred. The author of death and destruction thrusts his slimy tongue among them, which, having once touched, they, adhere, and draws whole armies into his mouth at a time. None can escape; the wonderful communal dwelling, with all its busy multitudes, is left a desolate and empty ruin, a hiding place for the jackal, a den of serpents, or a ready-made grave for a dead native.

\section{DOGS THAT ARE NOT DOGS.}

\section{HOW THEY LIVE.}

The prairie dog does not in the least look like a dog, act as a dog acts, or eat what a dog eats. In fact, the prairie $\operatorname{dog}$ is not a dog at all, but a little animal that looks like a small woodchuck, belonging to the squirrel or marmot family. He is probably called a dog because of his sharp, barking cry. Prairie dogs build villages, towns, and sometimes what may be called large cities, since one may sometimes travel for hours through their long streets or pathways before reaching the end of the space inhabited by them. "The hillocks everywhere," says Professor Gill, in the admirable description he gives of prairie dog towns, " has each its tenant half upright at the mouth of his hole, with his yaws folded down, vociferating his curiosity or displeasure, and, on too near approach, duck- 


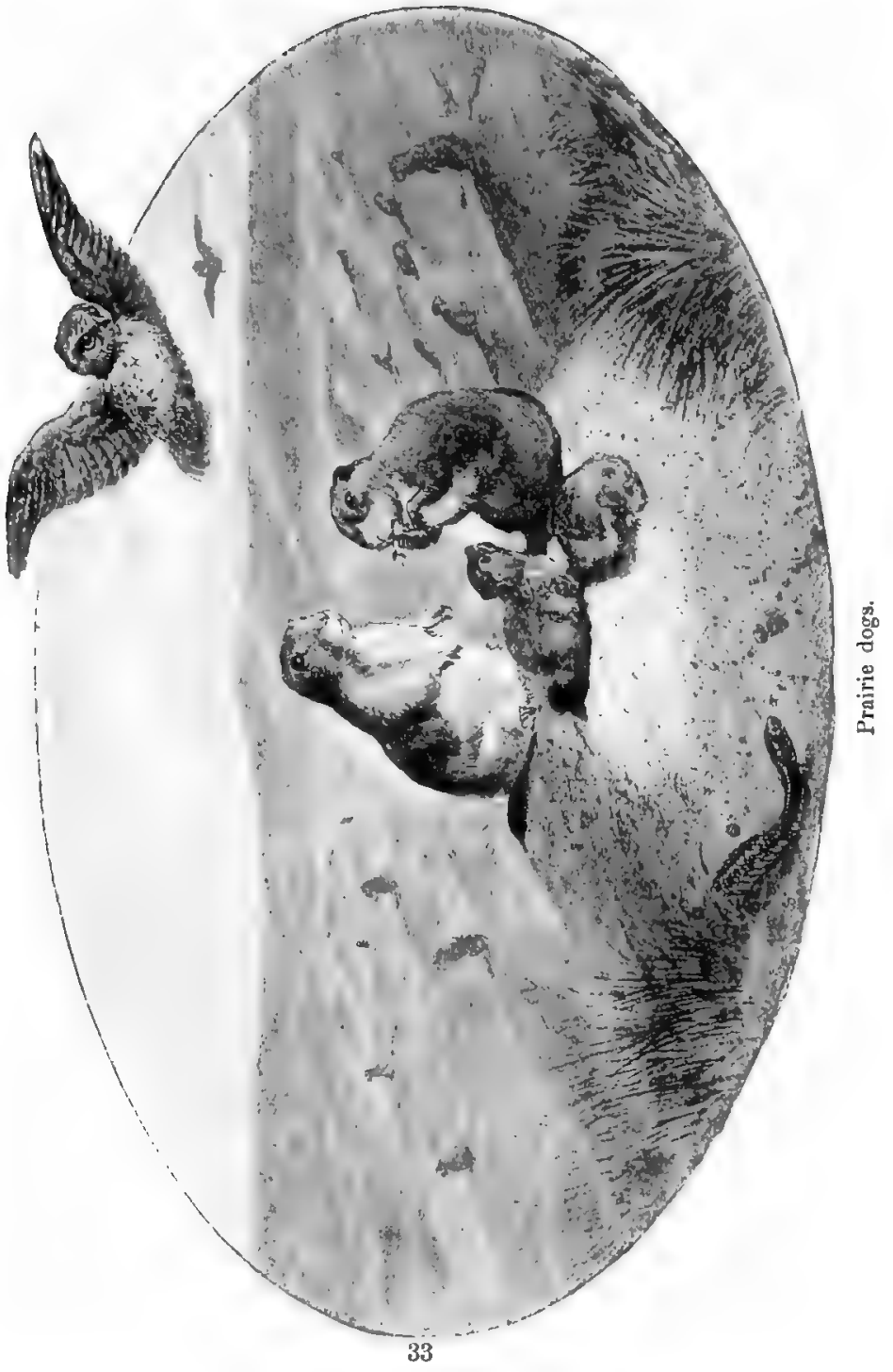


ing down like an automaton on springs, with a saucy 'good-by-I have business' flirt of the tail. These sharp cries are incessant. As each note is emitted the body shakes, the tail jerks, the whole performance being ludicrously like that of a toy barking dog, which . squeaks and drops its jaw as you press the bellows." *

Bushels of earth are thrown out at the mouth of every burrow and heaped into mounds two or three feet in diameter and about two feet high. These are to serve as posts of observation, as well as to prevent the nests being filled with water in stormy weather. Before and after a shower the little citizens may be seen gathering and inspecting the banks about their homes to see that everything is in a proper shape, and scratching up and patting down parts that need repairing.

Although no notices of "rooms to let" appear, the owners of many of the burrows are obliged, much against their will probably, to entertain lodgers who, instead of paying rent, exact cruel tribute of their hosts. These objectionable intruders consist of rattlesnakes and burrowing owls, the latter scarcely as large as a quail, who live with, and also live on, their poor little prairie dog losts, devouring both them and their children. In the rattlesnake, especially, the prairie dogs have a deadly foe, for neither by day or at night are they secure from his attack. Their deep nests softly bedded with dry, warm grass, are admirably adapted to his ease and comfort, and with his bed is furnished delicate food, the flesh of the baby dogs.

* Standard Natural History. 
Sometimes, however, the snake gets worsted, is bitten by the little animals in their desperation, and dies along with those he has struck with his poisoned fangs.

Owls and serpents are not, however, the only enemies prairie dogs have to encounter. Hawks swoop down from the sky above upon them, and the coyote or prairie wolf lies hidden behind their hillocks in wait for them. One way of escape from their numerous enemies is to be found in the great complexity and extent of their burrows underground, rendering it impossible even for man either to dig or drown them out. Many of the towns of the prairie dog are built in sterile and arid plains far from water, and it was supposed the little animals could, like guinea pigs, do without water, but when domesticated they drink often and freely; and it is now maintained that the dogs actually dig wells, each community being supplied with one that has a concealed entrance.

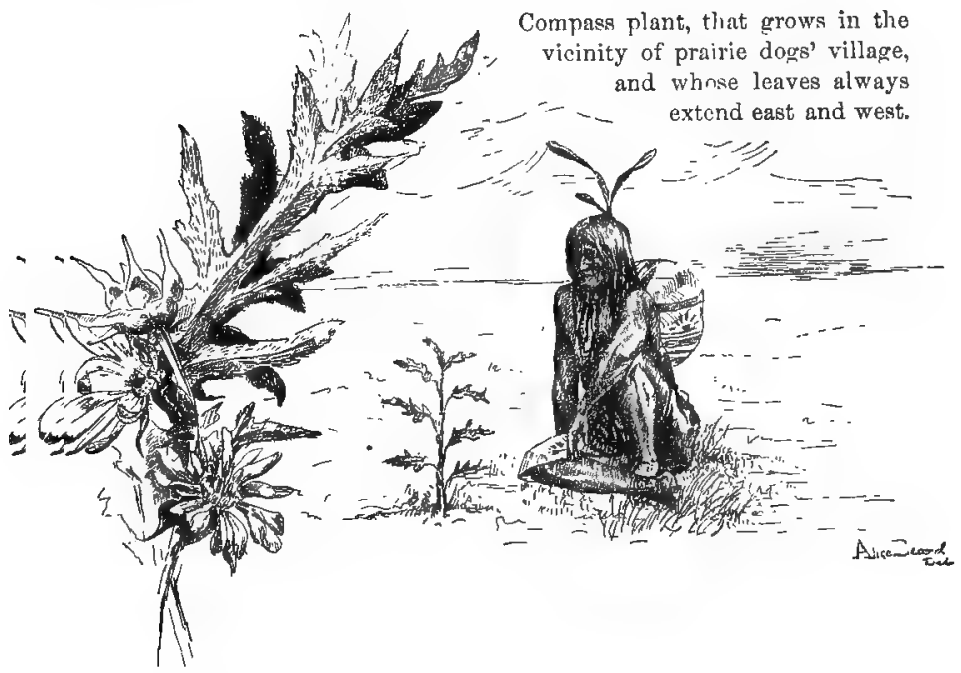




\section{BANK BURROWERS.}

\section{TWO KINDS OF MUSKRATS.}

The Indians used to call the muskrat the beaver's younger brother, both because it was smaller, built houses, but not quite so skillfuliy as the latter animal, and because it resembles the beaver so much in its habits of life. We are apt to accuse the Chinese and several other nations of a repulsive diet because they are said to eat rats, but many folks among our own people eat muskrats and are very fond of them; and the muskrat really is, as its name implies, a rat, a water rat, though, to be sure, a very large one, for he grows to be a foot in length. He occasionally builds himself a house of mud, strengthened and covered with reeds and strips. This house contains a single apartment, from one and a half to two feet in diameter, furnished with a bed of soft grass and sedges, and is enterer by a passage that opens under the surface of the water. In this chamber the muskrat spends the winter.

A member of still another family-and not only of another family but of another order, which is a much wider distinction-is called a muskrat because it gives out, like the muskrat, a strong, musky odor, and is an aquatic animal. The tail is scaly, like that of a beaver, and flattened up and down (vertically) instead of sideways (horizontally), as in that of the animal 
just mentioned. The desman is one of those cases that occasionally occur in the animal kingdom where an animal belonging to one family resembles very closely in its habits another belonging to another family.

Like the muskrat, he generally has his dwelling in the bank of a stream in which he disports himself; it consists of a chamber with numerous passages, all of which open under the surface of the water. The burrows he makes in the banks of streams and ponds are almost exactly like those dug by the muskrat, consisting, as they do, of long passages opening at one end under the surface of the water, and the other into a chamber three or four feet above the water level. Its name, desman, is probably from a Swedish word meaning musk. It is not quite as large an animal as our muskrat, but somewhat resembles it in the shape of its body and the character of its fur, which is very close and dense, consisting of a coat of fine hairs next the skin and longer hairs that cover them, making a beautiful waterproof garment, ashy gray beneath and reddish brown, showing a silver luster in certain lights above.

The desman is hunted for its fur, but, unlike the former animal, it is never eaten. It has a rather peculiarly shaped tail, narrowed at the root, almost cylindrical for some distance, and then flattened from about the middle to the end. Neither the beaver nor the muskrat uses its tail otherwise than as a rudder, but the desman employs his as an oar, by means of which he sculls himself along, and, as might be 
expected, aided by his powerful webbed feet, excels both the beaver and the muskrat in the rapidity and force, both in swimming and diving, of his progress through the water.

The most curious part of the desman is his movable trunk. It is, it is true, shorter in proportion to the size of the animal than that of an elephant's, but it seems to be used much in the same way and for the same purpose.

"It is brought actively into play," says Professor Dallas, "in the search for provisions. It is turned and twisted in various directions, touching the different objects that come in its way, which it seizes and conveys to its mouth after the same fashion as does the trunk of an elephant. The auinal is said to frequently put its ridiculous-looking trunk in its mouth and then quack like a duck," but why it commits this absurdity is not stated. So strongly is the desman flavored with the musky odor that gives it its popular name, that it is not only uneatable itself, but communicates a like smell and flaror to fish that sometimes devour it. The desman does not eat vegetable substances, but lives entirely upon insects. 


\section{A LITTLE QUADRUPED THAT LAYS EGGS.}

WHAT IT LOOKS LIKE.

If the question arises which of the mammals living at the present day-taking into consideration its habits, outward shape, and anatomical constructionis the most extraordinary, the decision might hang in doubt a long time but for the existence of one animal so singular in appearance, so strange in its physical makeup, and in some, at least, of its habits, that the answer must of necessity name it and no other. This is the Australian duckbill. To the head, bill, and webbed feet of a duck it seems to unite the body and tail of a quadruped; and to more distinctly mark its birdlike affinities, it lays eggs-a fact formerly doubted, but now known to be true.

It has other birdlike peculiarities of structure united to some that suggest the reptile tribes. One very singular formation, the like of which, with one exception, is possessed by no other animal, is a sharply pointed movable spur on the heels of the hind feet of the males. A canal, as it is called, or empty vein, runs from a little opening near the point of the spur back to a passage that leads to a large gland situated in the thigh. The whole apparatus is so like in its structure that of the poison gland and tooth of a venomous snake as to hint at a similar use and purpose, and there is proof that it sometimes, though not often, 
is employed in this way. It is known that one person at least has been wounded and very severely poisoned with the spur of a captured duckbill.*

Duckbills do not travel about much on dry land; their legs are much too short to make rapid progress in that way possible, but they can swim very rapidly both on and under the surface of the pools and stre.ıms they frequent. Their nests, sometimes fifty feet from the mouth of the passage that leads to them, are situated in the banks of the stream or pool, in which they spend most of their time. These nests are placed in a cavity hollowed out for the purpose, and are formed of dried plants. The passage leading to them, besides being long, is very crooked, bending and twisting in every direction, as if to discourage any one following its windings in an attempt to discover the place where the eggs are laid and the little family of from one to four nestlings are reared. The young duckbills when first hatched are entirely naked, like baby mice, and their bills are very short and broad, with smooth, fleshy edges. When they sleep they have, in common with the old ones, a curious halit of rolling themselves up into tight little balls that look like anything rather than living animals. When taken they soon become very tame. A gentleman who kept several of them for pets says:

"In a few days the young ones appeared to recognize a call, swimming rapidly to my hand as I paddled

* Mr. Spicer, as related in the Procecdings of the Royal Society of Tasmania for $18 j 6$, p. 162 . 
it about in the water; and it is curious to see them attempt to get at a worm inclosed in the hand, which they take very greedily when it is offered to them. I have noticed they seem to be able to smell whether I have a worm in my closed hand or not, as they swim up to it, for they desist from their efforts if an empty fist is offered them." Their natural food consists mainly of fresh-water shrimps, water fleas, and beetles.

The appearance of a duckbill does not lead to the belief that he is a burrower, but his fore quarters are very strong, and well braced with powerful bones. The burrows he digs have two entrances-one well hidden amid plants above the surface, and the other opening below the surface of the water. The nests are always placed above high-water mark, so the wise little animal is never drowned in his burrow by a sudden rise of water.

\section{THE PORCUPINE ANT-EATER.}

ANOTHER EGG LAYER.

In the bottom of a prickly pear cut four little flaps, turn them outward, let the fruit rest upon them, and you have a tolerably accurate representation of a porcupine ant-eater or echidna. The stem of the pear is the snout or beak, the flaps the feet. It has no legs worth mentioning, and the prickly body of the fruit may give you a pretty fair idea of the remainder of the animal. Possibly two very small 
black beads for eyes and a more liberal amount of prickles might increase the likeness, but otherwise it is not bad. The bill of a duckbill resembles the beak of a duck in almost every respect, but the bill of an echidna looks like that of a snipe or woodcock. The

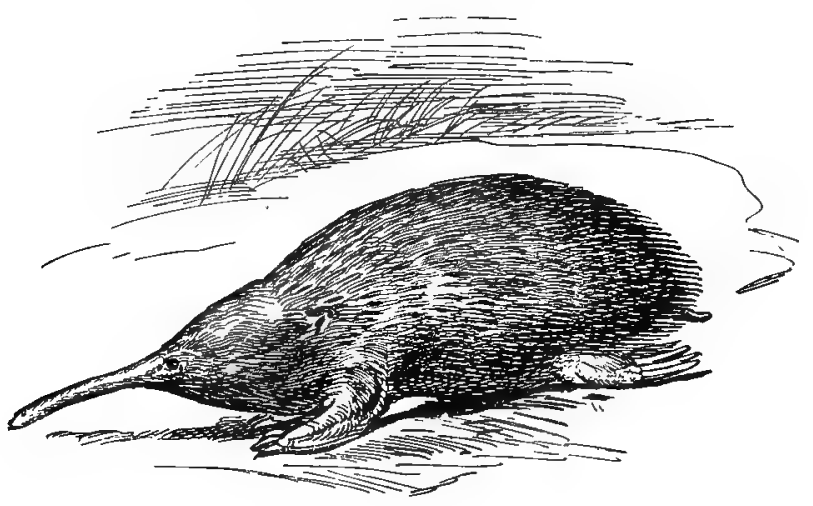

Echidna.

similarity in this case is, however, only a superficial one. The bill of the echidna does not open; it is a mere tube or quill, on the outer end of which is placed the nostrils, and the little valve or flap that answers the creature for a mouth. Through it is thrust out the long, slim tongue, to which stick the ants or whatever food it eats.

Its burrows are in the sand, but it also makes use of the crevices of rocks for its dwelling place. Its system of burrowing has never yet been fully investigated, but in all probability consists-as do those of most, if not all, inammals that are burrowers-of a 
complicated system of passages leading from the open air to the well-hidden chambers where the animals sleep, and where they have nests for their little ones. For the echidna is a famous burrower. Set him on the sand, he gathers his feet under him, sticks his long nose into the soil, and dives underground like a mole. His clinging powers are remarkable : digging his long, powerful nails into the smallest crevices, he retains his hold with a tenacity that nothing can unloose. Like the duckbill, which he resembles in more than one particular, he has the power of rolling himself into a compact ball, which he does when attacked on gromud into which he can not burrow, looking in that posture like an immense chestnut bur.

Like the duckbill, too, the porcupine ant-eater lays eggs. The eggs are large, and inclosed in a tough eggshell. After they are laid they are carried in a pouch in a fold of the skin until they are hatched.

\section{JERBOAS AND JUMPING MICE.}

\section{CHAMPION LEAPERS.}

Walking about the wooded regions of almost any State in the Union, a person may chance to see something like a little brown bird that takes short flights of from eight to ten feet, and no sooner alights than it is off again over bogs and bushes until lost to view. It is, however, not often met in the daytime, being nocturnal in its habits, and, in consequence, 


\section{CURIOUS HOMES AND THEIR TENANTS.}

extremely difficult to capture. If, indeed, it could be caught, its captor would probably be somewhat surprised to find that what had been taken was no bird at all, but a little brown mouse about three inches long, that had taken its flight without wings by the aid of its long hind legs. It looks something like a miniature kangaroo, except that it has a very long tail. It is, in fact, the American jumping mouse. It is an elegant, harmless, pretty little creature, living upon beech nuts and seeds of various kinds.

It makes its nest about half a foot under the surface of the ground, of fine grass, sometimes mingled with wool, hair, and feathers. In this nest the mother mouse has from two to four little ones, and it is a curious circumstance, carrying out to some extent her kangaroo-like form and habit of life, that she sometimes is seen with her little family clinging to her as she leaves her burrow in search of food. As a protection from the cold of winter, the jumping mouse is said to form "a little, hollow clay ball, in which it coils itself up and goes comfortably to sleep." Professor Tenney found one of these little animals, in January, tightly coiled up with its long tail wrapped airout it, in a grassy nest two feet underground. It seemed to be dead, but came to life fast enough when warmed.

On the vast sandy plains that shut in Egypt on the west, a part of the Great Salıara Desert, arid and waterless, and so scantily furnished with vegetation that it $i$ : hard to understand how any living creature can subsist, there are numerous societies of the remarkable 
little animals called jerboas. In company with a few species of birds and reptiles, they seem to be the only inhabitants of this barren and "thirsty land." According to the accounts given by the Arabs, the extensive and intricate burrows of this animal, consisting, as they do, of many branched passages dug out in the hard, dry soil, not far from the surface, are the result

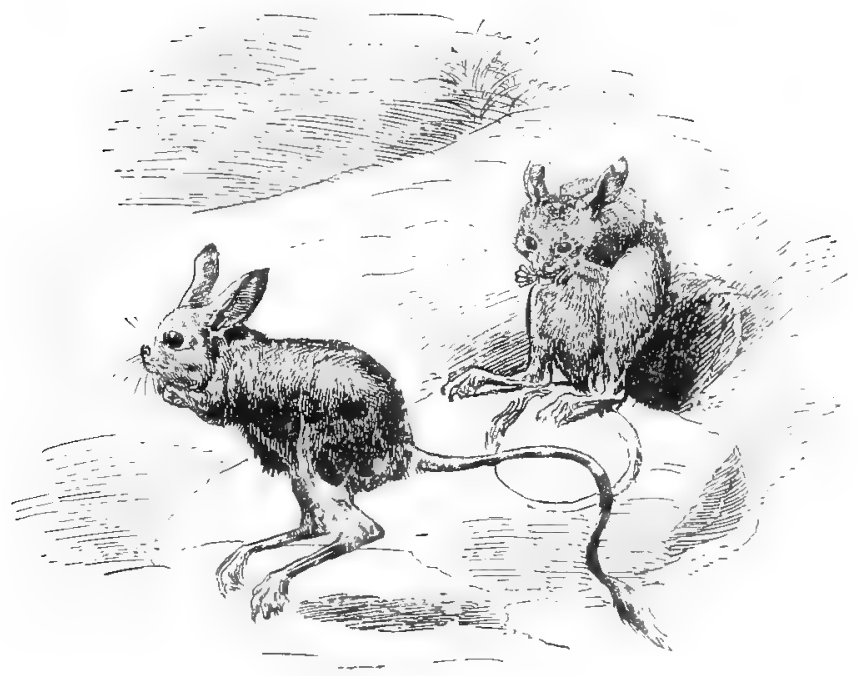

Jerboas.

of the joint exertions of the whole community, which, if true, is the only case known of any mammal, except man, building and occupying communal dwellings. On the least alarm the jerboas vanish into these underground villages, which have many openings, and here, in the deeper parts, the nests, in which the 
mothers rear their little families of from two to four jerboas, are made and lined with hair pulled from the breast of the animal.

In one species rather larger than that describodthe alactaga, in Central Asia-the animal employs a । stratagem that reminds one of that practiced by the trap-door spider. Like the African jerboa, it lives in a perfect tangle of burrows, ending in a large central chamber, and from this a long passage terminates close to the surface of the ground, quite a distance away from the other burrows. No trace of its existence appears above ground, but let the burrows be invaded, and away their inmates scuttle through this passage, break through to the surface of the ground far away in some place hidden by intervening objects from the scene of disturbance, and make their escape.

Anything so quaint and odd as the African jerboa is scarcely to be found. They are distinctively twolegged animals, more entirely so than any other mammal, monkeys, bears, and kangaroos included, except man; they never go on all-fours. When they walk they do so by placing one hind foot alternately before the other; when they run it is done in the same way by hastening their steps, and they might readily be taken at a little distance for small birds. When they leap they cover such an extraordinary space in proportion to their size, and touch the earth so lightly and so rapidly between their jumps, that unless it was known what they really were no one would believe them anything else than small birds skimming along the surface of the ground. 


\section{A FELLOW WITH POCKETS IN HIS CIIEEKS.}

HOW HE FILLS THEM, AND WHAT HE FILLS THEM WITH.

A gentleman of considerable scientific attainments once told me that while waiking through a cornfield in eastern Missouri he was considerably surprised to see a cornstalk move as of itself, tremble, and slowly sink bodily into the earth. Not knowing what to make of such a remarkable phenomena, he hastened to the spot, and examining the earth where the plant had vanished he saw a pile of loam or fresh earth that immediately explained the cause of its disappearance : it had been dragged underground by one of the pouched gophers so numerous in the valleys of the Mississippi.

"Yes," said the farmer, the owner of the cornstalk that had disappeared, and of the cornfield where it grew, to whom my friend related the occurrence, "yes, this is only an instance of the manner in which pouched gophers rob the farmers. You can't catch the rascals at work and scare them off as you can birds and beasts that belong above ground. Even if the fields could be watched day and night, and every living creature that dared to appear were driven away, the pouched gopher could ruin your crops just the same. You can't see what is going on in the earth under your feet. You may to some extent get the best of birds and bugs, but you can't get the advantage of pouched gophers." 
They travel long distances under ground, and can penetrate the soil as easily as a mole, but, unlike a mole, they do not live on earthworms; on the contrary, they seem to know just where to find the farm-

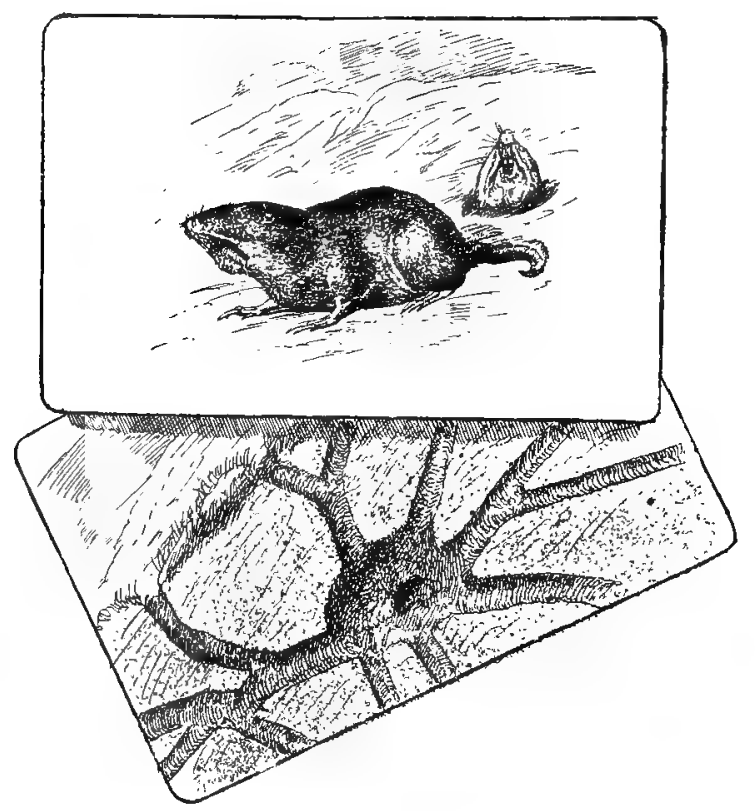

Pocket gopher and nest.

er's choicest potatoes, carrots, turnips, and the like, just as well beneath as we above the surface of the ground by the aid of our sense of sight. Not content with eating all they can, they stuff their pockets full and carry off what they can not eat. Their pockets are in their cheeks-a couple of large skinny bags that 
reach back to the shoulders; they have no neek to speak of. It was once supposed they packed their cheek pouches with dirt, but they have better use for them, for by their aid they fill with food the extensive underground granaries that, in addition to the chambers they in common with most burrowing animals employ for their nests, they also excavate.

They are wise animals, much better able to take care of themselves than most four-footed beasts. You may live a long time in their vicinity without seeing one, and they are always wide awake if by any chance they do poke their noses above ground. They can run quite swiftly considering their rather clumsy build, and, if caught, can and do bite terribly. Their yellow front teeth are very large, and capable of inflicting a fearful wound. The different species average in size a rather large house rat. Some are smaller than this; others, again, are as large as a muskrat. They are, as may be seen in the illustration, stoutly built, with claws adapted to digging, a rather short tail, and very small eyes and ears. Their fur is soft and much like that of a mole.

The bed on which the mother gopher and her young ones rest is in a little round chamber like the inside of a football. It is made of soft grasses and of fur plucked from her body. A great many passages center in this chamber, which enables the gopher to reach her feeding grounds or to escape in any direction from threatened danger. A sectional view of this apartment is shown in the illustration under the figure of the animal. 
When captured the pouched gopher does not care to live any longer-that is, provided he can not escape, which he is very likely to do unless fastened in some place where even his sharp, strong teeth can not gnaw his way out. He then becomes sullen and unmanageable, and so ugly and quarrelsome that he will fight to the death either with a comrade in captivity or any living creature that is shut up with him. "Liberty or death" is the watchword of the whole pouched gopher tribe.

\section{THE DIAMOND BIRDS AND THEIR NESTS.}

\section{a beautiful nest in a hole in the ground.}

Most birds that burrow are content with very little in the way of a nest; even a few tufts of grass or feathers, or dried leaves, are often dispensed with; but the diamond bird, well named to suggest the brilliancy of its plumage-though one would scarcely expect such a bird to have a nest anywhere but in the tree, perhaps in the hollow of a tree, certainly not in a hole in the ground-digs galleries two or three feet long, at the end of which it hollows out a chamber to contain its nest-a chamber that is the wonder of any one who sees it. The entrance is only sufficiently large to allow the little creature to pass through it; and she is only three and a half inches long, tail and all, but the farther end of the hole is raised so that the rain can not come in, and enlarged to three inches in di- 
THE DIAMOND BIRDS AND THEIR NESTS. 51 ameter. Here an apartment is formed for the mother and her eggss or nestlings. It is shaped like the inside of a small globe, and most beautifully formed of

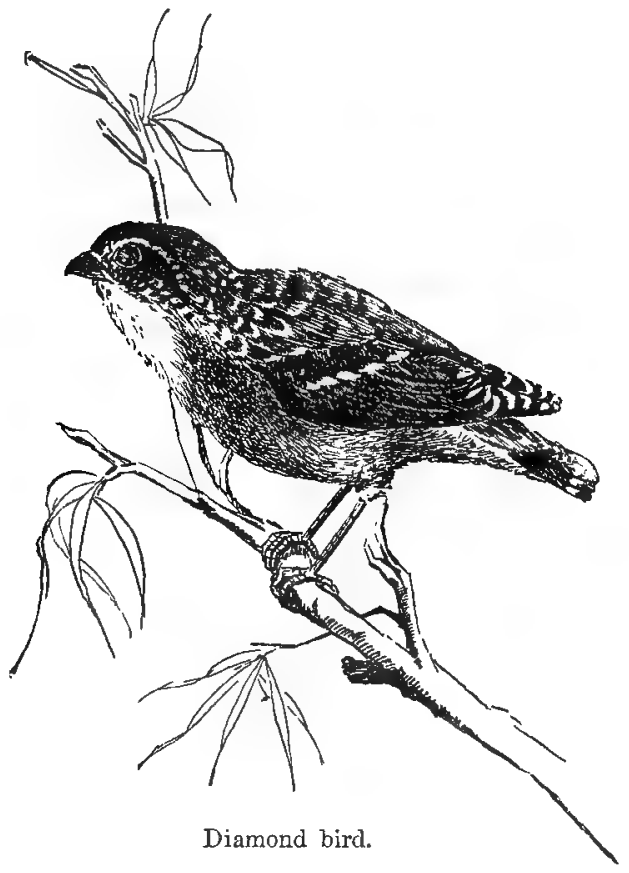

scraps of the bark of gum trees, woven with a perfection of neatness that is really wonderful, especially when we consider that the process of its construction is carried on without a ray of light to guide its clever little architect.

The diamond bird is a sprightly pinch of lightly colored feathers, as it flies energetically from bush 
to bush in pursuit of insect fare, often entering the garilens of the settlers in southern Australia and Van Diemen's Land which it inhal,its, incessantly uttering its pleasing, piping note of two syllables, which may be translated into the words, What next? what next? The crown of the head and the wings and tail are black, with a round, whice, brilliant spot at the tip of each feather. A white strip passes above the eyes. The cheeks and sides of the neck are gray, and the feather's on the back are gray, shading into brown at their roots, and edged with black at their outer ends. The uppermost tail covers are vermilion red; the throat, breast, and lower tail covers bright yellow; the belly and sicles are orange, the eyes deep brown, the beak brownish black, and the feet brown. But to appreciate the beauty of his apparel you should see the bird make it flash and sparkle in the sun, every feather vibrating as he palpitates in his active, eager flight, or dives in and out among the leaves and blossoms like the play of iridescent color thrown from

a prisin.

Parasol ant, carrics a leaf over its head.

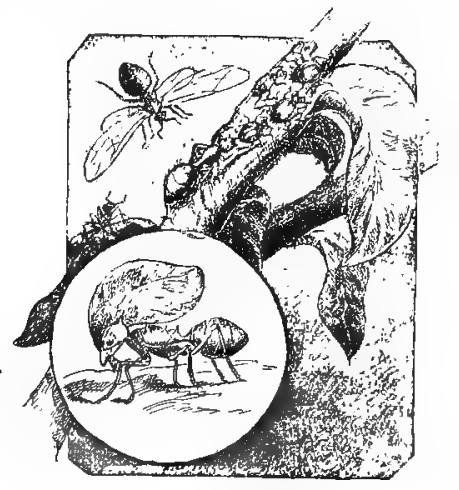

Ant milking aphides, which it liceps as cattle. 
$\triangle$ BIIRD BURROWER-THE PUFFIN.

\section{A BIRD BURROWER-THE PUFFIN.}

A HOME-MAKER AND A HOME-TAKER.

Birds are not as easily adapted by nature for burrowers as are mammals. Although a considerable number of species live in caves and holes of different sorts, there are few true burrowers among them. Some, like the kingtisher, will make over and alter and adapt a deserted burrow to suit its convenience. But even the sand martin, perhaps the only winged creature that invariably excavates its own tunnels in the earth, though capable of sinking her shaft in sandstone hard enough to turn the edge of a knife, never fails to select the lightest and most easily penetrated soil or sand for her purpose.

One of the bird burrowers is the queer little puffin. She has, however, not the slightest objection to taking advantage of the labors of others. If, for instance, she has a fancy for a dwelling already occupied by a rabbit and her family, she walks in without knocking and evicts the owner with small ceremony but considerable violence, using her powerful bill as a weapon with such effect that Mrs. Rabbit and family are not apt to stand long on the order of their going, but to go at once and set at work to dig another burrow. Having obtained possession of the premises by the oldest and most inalienable of rights - that of might-Mrs. Puffin does some excavating on her own account, and makes such additional gal- 
54 CURIOUS HOMES AND THEIR TENANTS.

leries and chambers as she thinks proper. In one of these she lays upon the bare earth, according to the immemorial custom of diving birds, one white egg, to

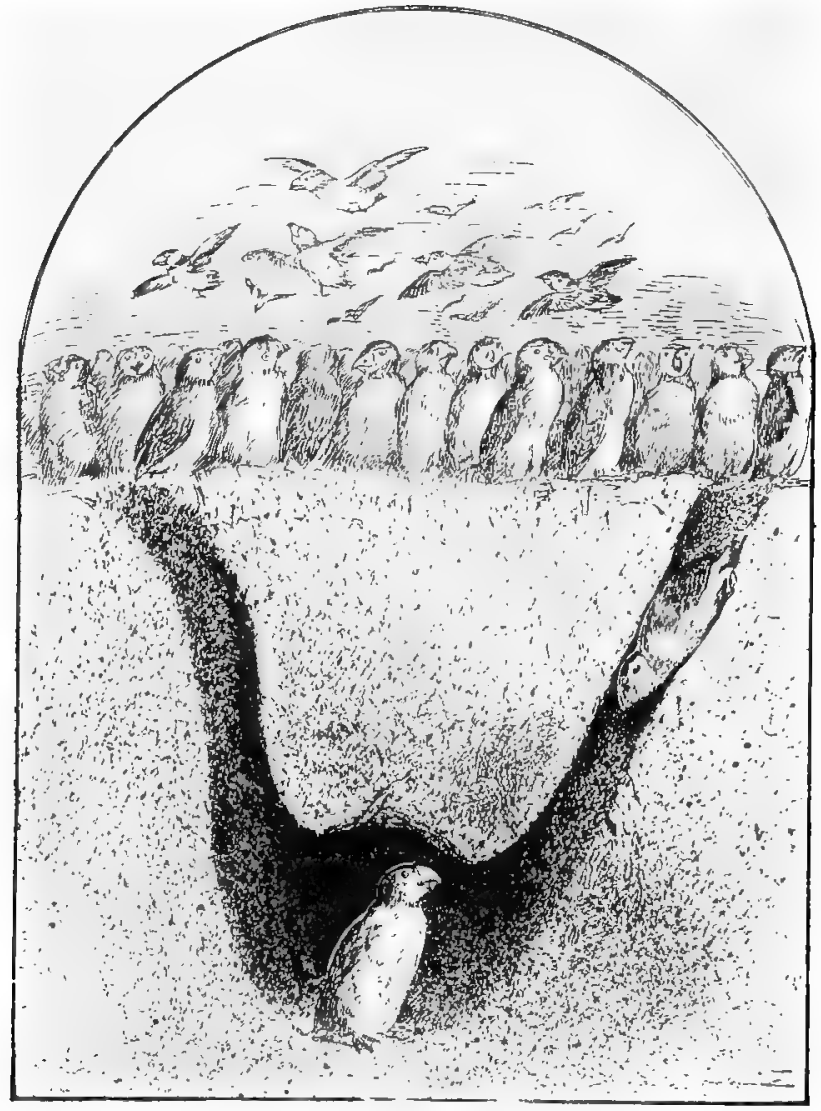

Burrow of the pultio. 
which she devotes the whole of her attention until the queer little fluffy click makes its appearance.

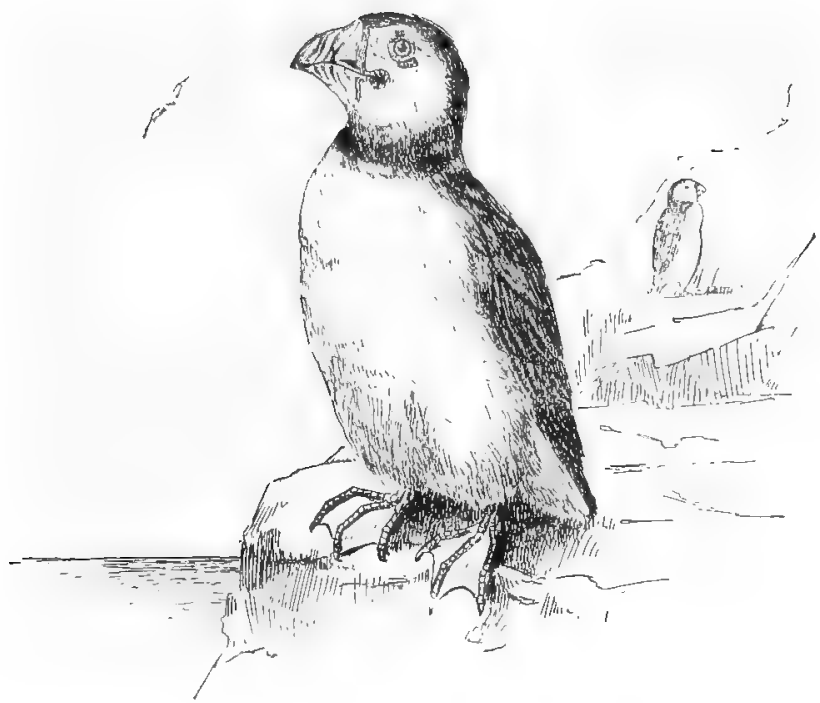

The baby puffin, though it is the object of considerable attention on the part of many birds and beasts who are so fond of the baby that they would fain eat it, is bravely defended by its mother, who on occasion will seize her enemy with her beak and " hurl herself and her foe into the sea."

On the water she feels herself invincible, for the waves are her fortress; she can outswim, outdive, and outlast any opponent she is likely to encounter in such a combat. Indeed, a puffin is in all proba- 
bility not to be found at home by objectionable callers; her burrow is curved, and has two entrances, and while the enemy enters the front door she and her chick escape by the back and plunge as soon as possible into the water, where they can with little exertion burrow as often and as rapidly as they choose.

If you ever happen to be walking upon the edge of any of the sea cliffs with which the Färöe Islands abound, you need not feel any surprise to hear a fierce grunting going on beneath your very feet. It is only the old puffins who frequent the place in great numbers, and whose burrows run deeply into the banks; they are angry with you for disturbing their slumbers by tramping over the roofs of their dwelling places.

\section{THE TURRET-BUILDING SPIDER.}

\section{THE LOG CABIN SHE BUILDS.}

The $\log$ cabin or turret spider digs a burrow in the earth six or seven inches in depth and builds a tower of sticks above its burrow, as cabins are built of logs, by placing the sticks alternately one upon the other and filling the interstices with earth and moss.

The turret is constructed of these sticks, which are an inch or two in length, in such a manner as to have five sides and to reach the height of two or three inches. Mrs. Mary Treat, the discoverer of 
this spider, describes the building of the tower. She says the spider readily accepted her help in constructing her habitation.

Madame Spider had been put in a jar which contained six inches of earth, together with a lot of building material in the shape of sticks and moss. It was not long. before her burrow was begun, and when it measured two inches in depth she commenced her turret above it.

She did not refuse to take sticks offered her from the fingers of Mrs. Treat. Standing inside of her tunnel and holding the stick in her fore claws she arranged it as she saw proper and fastened it in place with a stout bit of cobweb, and having done Burrow of the turret-building spider. so. accepted another, which she used as she did the first, and so proceeded until the foundation of her five-sided domicile was laid. She then disappeared inside her burrow, and soon came to the top again carrying a pellet of fresh 
earth, which she put on top of one of the sticks, and went on doing this until there was a complete circle of these pellets arranged on the inside of her five walls.

The soft earth was flattened and molded into shape by the pressure of her boly, so that the inside of the turret presented a perfectly round, smooth surface, which was at once lined with silk. More sticks were now required and furnished, another course laid and finished, and still another, until the little log cabin was two inches and a half high over her burrow. Mrs. Treat presentel the little architect with strips of green moss one or two inches in length, which she. secured to the ontside of her turret with cobweb. This gives her tower a very dainty and picturesque appearance.

Mrs. Treat says that Madame Spider is a very neat housekeeper, and never, as sorne other spiders do, leaves the unpleasant remains of her dinner in sight, but goes on top of her house and throws it as far away as she can-a foot or two from her burrow.

About the end of July Madame Spider appeared with a cocoon of eggs, like a light-colored globe fastened to her spinneret, to which she gave constant care and attention.

If the weather was cold or damp, she retired to her tunnel; but if the jar in which she lived was set where the sun could shine upon it, she soon reappeared and allowed the cocoon to bisk in the sunlight. If the jar was placed near a store that har a fire in it, the cocoon was put on the side next the source of 
warmth. If the jar was turned around she lost no time in moving the cocoon to the warmer side.

Two months after the eggs were laid the young spiders made their appearance, and immediately perched upon their mother, many on her back, some on her head, and even on her legs. She carried them about with her and fed them, and until they were older they never left their mother for a moment.

\section{CTENIZA.}

HOW AND WHERE THEY CONCEAL THEMSELVES.

Visitors to Arizona, New Mexico, or California, sitting meditatively, without noise or movement, beneath some tree or elsewhere, are sometimes astonished beyond measure to see small circular doors, like those that cover manholes in the streets of New York suddenly lift up in the soil about them, and

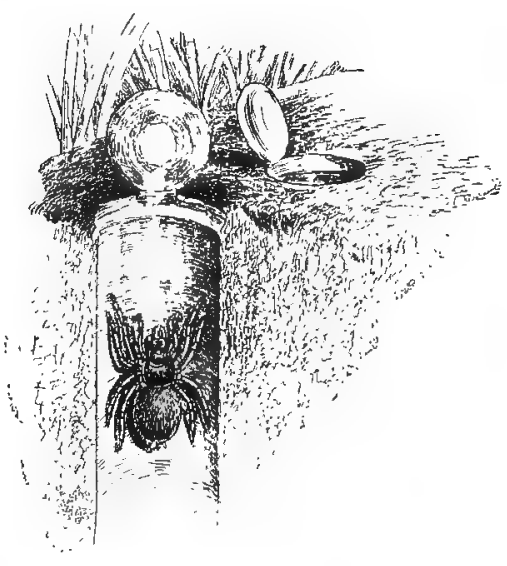

Burrow of the eteniza. what might be taken for the hairy heads of outlandish little pygmies peep out. 
The slightest movement on the part of the anazed spectator, who can scarcely credit his eyes, is a signal for the immediate disappearance of doors and dwarfs, of which, even on the most careful examination, not the slightest trace remains. It may be a long time before the person who has had such an experience meets a true explanation of the phenomenon, for the people who live in the wilder parts of these States and Territories are not naturalists, and it is almost too strange a story to tell after returning to more civilized parts of the country.

The truth is, the pygmies seen, called cteniza by scientific folks, mule-killers by the natives, are trapdoor spiclers. The holes they live in are sometimes twelve inches deep and an inch in diameter; the mouth is a little wider, and is covered by a thick lid that fits snugly in it. The lid, or trapdoor, is made of earth fastened together with threads of cobweb, covered on the underside with silk that also lines the hole or tube it covers, and is the material of which the thick hinge on one side is made. When the cover is shut it is impossible to distinguish it from the ground about it. Even if the exact spot it oceupies is located, when it lappens to be lifted by the spider inside, it is still impossible, without tearing, to raise it again after it is closed, for the inmate of the tunnel holds it shut with jaws and with her first two pairs of feet, while the other two pairs are firmly braced against the walls of the tube.

There are in Europe trapdoor spiders that practice a sort of legerdemain trick to deceive wuuld-be house- 
breakers. The covers of their burrows, instead of being thick and fitting into the hole like a stopper, as is the case with those of the California trapdoor spiders, are thin, covered with moss, dead leaves, or whatever happens to be scattered over the ground where they are, and lie loosely upon the mouth of the burrow. Two or more inches down the tunnel, however, is another door, hinged to one side of the tube, open and hanging down when not in use; but no sooner is any attempt made to lift the upper lid, than the lower one is pushed up and shut by the spider under it, and then looks exactly as if it were the bottom of an empty tube.

Another species improves upon this trick by digging a branch tunnel from the middle of the tube in a slanting direction to the surface, and hanging a door at the junction of the tubes, so that it can be used to close the way to either of them as occasion requires, while the householder escapes to the one which has not been broken into.

The flap or lid of the tubes of all trapdoor spiders is always so made that when it shuts it does not fall in the slightest degree to the right or left, but comes down exactly upon the opening it covers.

Where the burrow is dug on a slope of ground, as it almost always is; the hinge is invariably uppermost, so that when raised the door falls shut of itself. In 1 the case of the American trapdoor spider, and others, where the lid is thick, it is neatly beveled off inward, so as to tightly and accurately fit the socket or frame into which it falls. All others, also, where 
the door is a mere flap of dried leaves and sticks, fastened in place with cobwebs, have the upper edge more or less irregular, and covered with all sorts of projections, so that no well-marked line on the ground betrays its presence when closed.

\section{BEES AND WASPS AS MINERS.}

UNDERGROUND NURSERIES.

The old-fashioned stanza beginning

IInw doth the little busy bee

Improve each shining hour, And gather honey all the day From every opening flower!

published when verses for children were by no means as common as they now are, and more familiar to the grandparents and great-grandparents of the young folks of to-day than they are likely ever to be to the present or to any future generation, may be excellent poetry of its kind, but it is misleading as to fact. The little busy bee does not work all day, nor every day, nor does she choose, as a rule, flowers not yet opened from which to gather her honey. Again, although the bee is the trade-mark of labor, the sign and symbol of diligence, and the badge of industry, it is from the name of the male insect that we obtain a word that best of all describes an idle, useless fellow. But it is also true, though not generally known, that there are whole tribes of bees, both male and female, 
that never in all their worthless lives do a stroke of honest work.

These cuckoo bees, as they have very appropriately been called, have no means provided, as have other bees, in the way of widened hind legs bordered with bristles, nor thick coats of hairs on the lower parts of their bodies, for collecting pollen.

The common working bees look heavy and clumsily built compared with thein; their smooth, shiny, and slender bodies are adorned with the richest of colors; they are aristocrats among the bees, fashionable folks, who spend their days flying about for pleasure. They make their way into the homes of nest-making bees in the absence of the rightful owners and deposit their own eggs on the masses of food stored up for the interided occupant, the children of the laborers.

Nest-making bees are another variety of the insect we know so well. They are solitary bees, and do not live in hives. There are many sorts of them. Carpenters, as described elsewhere, work out homes for their babies in solid timber; masons, that build their nests of grains of sand cemented together; upholsterers, that cut out and piece rose leaves together; and miners, that sink shafts deep into the earth and make nurseries in them.

The Andrena bee burrows in light soil to a depth of from five to twelve inches. The tube belonging 、 to the species, shown in the accompanying illustration, is perpendicular, with small chambers, slanting downward at intervals, on different sides, and con- 


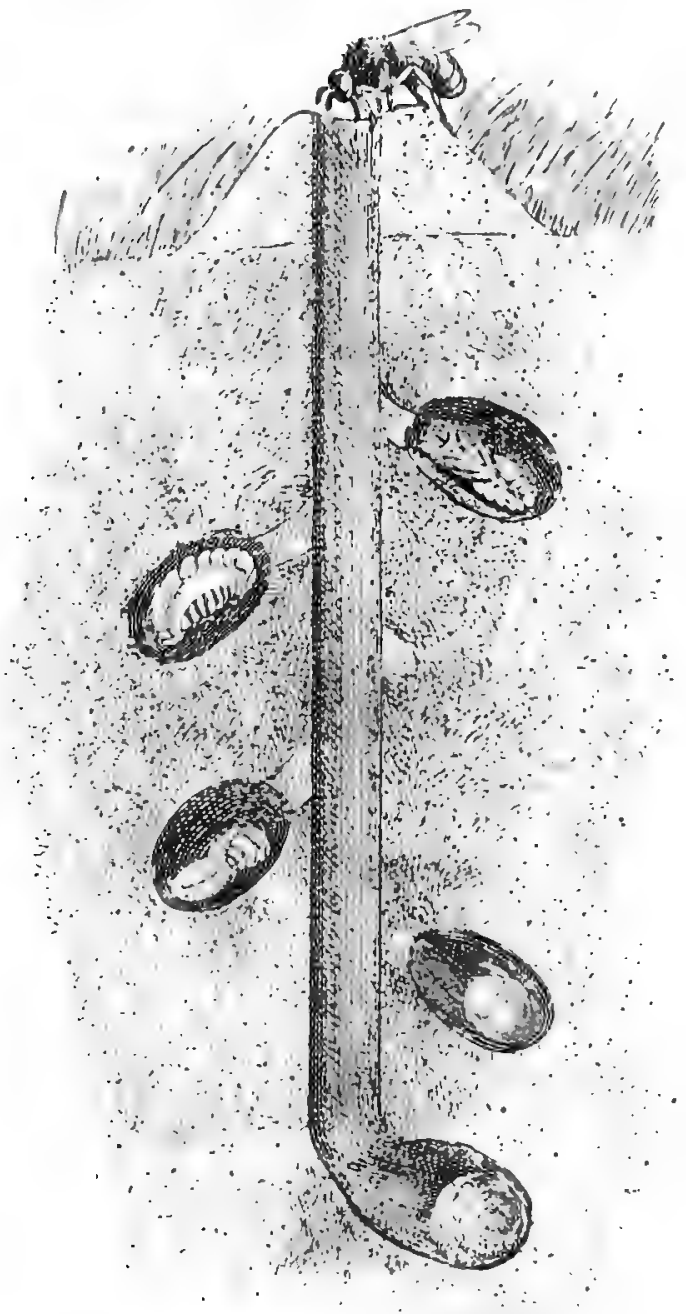


nected with the main shaft by short passages. The sides of the shaft are rough, but varnished over with a mucuslike secretion. After building these chambers

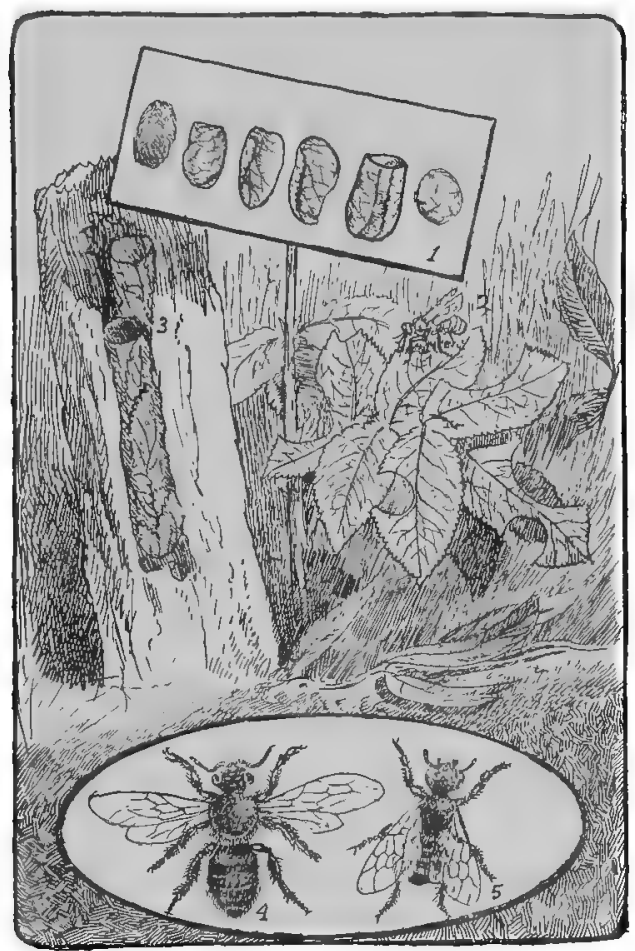

Rose-leaf bce.

the Andrena gathers balls of pollen and puts one in each chamber with an egg, which hatches out a grub that lives on the pollen until it is ready to make its 
way into the main shaft, and come out into daylight a full-fledged Andrena bee. The deepest chambers are provisioned last.

The mother bee can dig through the hardestpacked earth and gravel to make her tunnel. She does all the work herself. The fore legs of the male bee are not adapted for digging, nor his hind legs for carrying pollen.

The wasps are famous diggers, but instead of storing up honey or pollen for the use of their little ones, they capture living insects, which they have the power of paralyzing with their stings, and which they deposit with their eggs in their burrows. The effect of. the sting is very wonderful. Spiders stored away with wasp's eggs, which have failed to hatch, have been found after several years had past in the same condition as mhen first deposited.

It may seem very cruel to condemn living creatures to such a sort of life in death to fall a prey at last to hungry grubs, lout the insects, it is safe to say, are entirely unconscious and insensible to pain.

Our very large wasp in Texas * captures the gre $t$. hairy ground spider found there, $\nmid$ though the spider has been known to catch the wasp. This wasp makes a burrow fire inches deep for every egg it lays, and one spider is stored in each burrow.

Every species of wasp has its own particular species

* Pompitius formosus.

+ Mlygale Mutzii. Latin and Greek, a field mouse; a man's name. 
of insect for its food supply. Some capture locusts or grasshoppers, some cockroaches, some flies, others caterpillars, and so forth.

Species of wasps exist that make their homes in the sand, others in hollow stalks of reeds and other plants, and many that are glad to take advantage of any old hole or crevice they can find to save themselves the labor of making burrows. $\mathrm{Mr}$. H. P. Gosse tells of a dauber wasp * that made a nest of an empty ink bottle; stored it with spiders' and wasps' eggs, and stopped up the neck with clay. When this was broken into and the spiders overhauled, she visited it, took out all the spiders first put there, replaced them with others, and reclosed the neck of the bottle.

Wasps of another kind + have been known

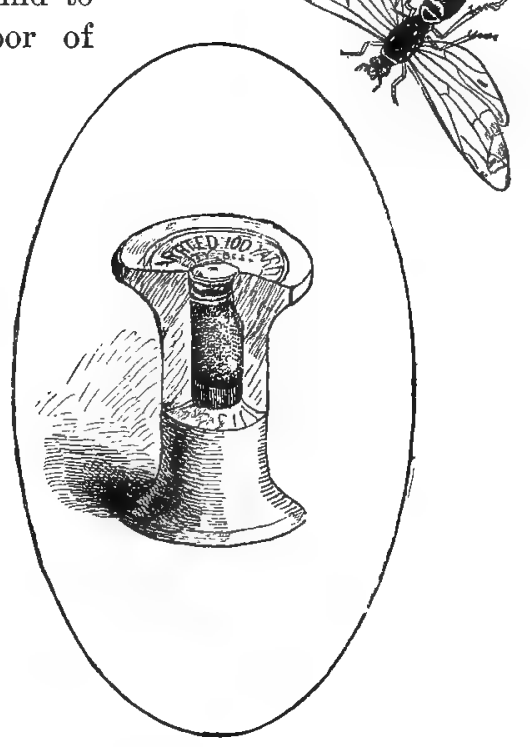
to use the folds in a piece of paper, and "even of the barrels of a double-barreled pistol hanging on the post of a garden summer house." On one oc- 
casion a wasp of the same genus made its nest, as shown in the illustration, in the hole of an old spool of thread.

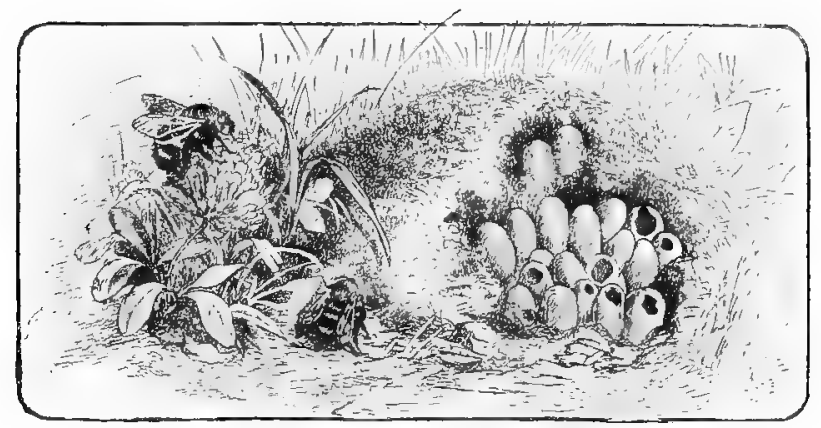

Bumble bee and nest.

\section{SENSES OF ANTS.}

TIEIR SENSE OF SMELL WORTH ALL THE REST.

A gentleman once placed a number of ants in a box closed at the sides, but in one corner of which he had made a small hole. There was a piece of glass in the corner that let in a little light, and through it he could see what was going on inside. At first the ants scattered and ran everywhere seeking an outlet to freedom. At last one ant found the hole, but instead of escaping by it the little insect came back and touched a number of its friends with its feelers, or antennæ as they are called, and these touched the rest. As soon as this was done all the ants formed 
into line and marched out of the hole, led by the one that first found it.

In this way it was seen that ants can talk to each other with their antennæ as we with our tongues, or rather, perhaps, as deaf and dumb people who are also blind do with their fingers.

If you place a dead fly near an ant-hole and an ant finds it, the little creature will try to carry the fly away. As the $\mathrm{fly}$, to it, is as large compared with the insect as an elephant is to you, the ant, although very much stronger for its size than the strongest man, soon sees it needs help. It leaves the fly and goes back to its ant-hill. If it meets an ant belonging to its own hill it touches the antennæ of its friend with its own and the two start off together, but it does not notice stranger ants. If it does not meet any friend, it goes down into its hole and presently comes out again with a number of house mates, that fall to work upon the fly and carry it home. It is not likely that ants can converse as human beings can, that they can call each other by name, or recite verses or tell fairy stories, for their sense of hearing does not seem to be very well developed; but without any doubt they have a language without words that answers the purpose of making their wants known to each other, and of telling each other such things as are necessary to the comfort and safety of the community in which they dwell.

Human beings think that seeing, hearing, and feeling are the most important of the senses. If a person can not see, that person is blind; if he can not 
hear, he is deaf; if he can not feel, he is insensible; if he can not smell-what is he? There is no word that describes the lack of the sense of smell, because the sense itself is so much duller and weaker than any other in mankind that its loss is not important enough to have a word all to itself. The same thing, in a degree, may be said of taste, though this is more developed than smell. With a number of animals the sense of smell is of even more consequence than those of sight or hearing, and this is particularly the case with ants.

Baby ants have been taken away from the ant family when they were born and brought up by themselves, and after a long time set free close to the anthill from which they were taken. As soon as any of the ants from this hill met them they knew at once that the visitor belonged to the family, and the new comers also knew their relatives, and went with them into the hill and lived there the rest of their lives. When, however, ants from another hill were introduced the poor creatures were attacked and killed or dricen atray.

Unless ants have a sense of which we know nothing, they must recognize each other by the sense of smell, as dogs know the footsteps of their masters. Indeed, unless their sense of smell is so well developed as to answer for that of sight, it is hard to understand how they can build and keep clean and in order their underground homes, and carry on all their domestic affairs-for they are notable housekeeperswhen their habitations are kept in utter darkness. 


\section{WORK VERSUS PLAY.}

HOW ANTS AND OTHER ANIMALS WORK.

I remember, when a schoolboy, building a brick house, and few recollections of my boylood days linger as pleasantly in my memory as this one. Several of us had obtained the privilege of using the corner of a brickyard in the village. We had our own clay mill, properly dug, in which we prepared our "malm" or mud, with which we filled our molds, the moist clay properly mixed with sand that went into the molds as mud but came out as bricks, delightfully firm and shapely, with true-cut edges and sharp corners. These had to be set on edge to dry, and when dry built into kilns and baked.

Few brickmakers, I fancy, worked harder or more faithfully than we did; and for what? The bricks we made, which were two thirds the size of ordinary bricks, were worthless except as playthings. We were paid no wages, and certainly, because our work soilcd our boots and clothes, to say nothing of our faces and hands, we received no praise or commendation for what we did. Our only pay was the delight we had in making our own bricks and building our own playhouse. It was the delight of doing-of doing work; no one ever would call it labor; we certainly never thought of it as such, any more than we did "tag," "I spy," ball, or any of our games. Properly 
speaking, it was play-work; and this is just what the so-called labor of bees, ants, beavers, and birds amounts to.

Men labor: horses, reindeer, and sometimes dogs labor; but only men, and the animals they compel to do so, really labor. Birds build their nests, bees make their honey, and beavers build their dams, because they find it delightful to do so. They work "for the fun of the thing," as a boy would say.

There are a great many mistaken notions indulged in by folks who get all their ideas about animals from what they read in books, and one of them is thinking and speaking of animal workers as they would of human laborers.

I ou may sometimes hear and read of the labors of coral insects and the islands they build in the southern seas. There used to be a poem, in the school reader I studied, describing their unselfish and lifelong labor; and Mr. Montgomery in one of his poems descrilses these architects, who, by touching slime, turn it into adamant, and with it build their own mausoleums.

Of course, this is all nomense. The coral animal is as far from being an insect as was Mr. Montgomery himself: and the coral, which is composed of the hard parts or skeletons of a number of such animals, is no more the result of their toil than are the bones in our bodies the effect of any labor on our part.

Animals, in a natural state, never do one thing when they would prefer doing something else. It may be thought that eats must find it tiresome to 
watch for hours at a mouse-hole, and that other animals undergo trouble and fatigue in seeking their prey, but there is nothing to show that they do not enjoy it; and the fact that in mere sportive play they will often do much the same thing, seems to argue that they take pleasure in the pursuit as well as the capture of game.

Certain birds that make very handsome nests have the instinct for building so strongly developed that they will go on working away at their nests after they are finished, and will even build others, seemingly with no other object than to gratify their love of nestbuilding. Beavers will try to build their dams, if kept in captivity, even if they have to build them of hair brushes, old rags, and bottles, in bedrooms and closets; and, without tediously giving instance after instance of the kind, it will perhaps be sufficient to recall the fact that bees, instead of resting when they have laid up ample store of honey to last for generations yet unborn, labor as assiduously as ever to still further increase their store.

Another mistake often made is that which credits insects with enormous strength in proportion to their size. A number of curious computations have been made to show what men could do if they were proportionately as strong as fleas and flies and bees and beetles. "An ant carries away a dead fly larger as compared with its own size than an elephant is to a man; a grasshopper leaps fifty or sixty times the length of its body, and termites rear edifices which to equal in proportional size men would have to erect 
74 CURIOUS HOMES AND THETR TENANTS.

structures taller than the highest mountains." The greater pull that gravitation exerts upon men as compared with insects is not taken into account.

It requires a number of ants to weigh a grain. Such an insect can fall from any given height without the slightest injury.

The materials - the muscle fibers and flesh - that go to make up an animal are as strong in an insect as in any other creature, but the resistance they have to meet in gravitation is very little. If other things were proportional as well as mere size, if gravitation had no greater hold on a man than it has on an ant, or if the material of which man is constructed were as much stronger as a man is larger than an insect, his strength and power would equal and surpass that of the latter. In other words, living creatures are and must be inore under the power of gravitation as they increase in size, irrespective of their mere muscular power.

\section{ANTS AT HOME.}

HOW THEY KEEP HOUSE.

There are no lawmakers among the ants, and no one rules over them. Like the bees, they have what are called their queens, but the so-called queens possess no power to command their subjects.

The fact of the matter is, every beehive and every ant-hill consists of an immense family of brothors and sisters, and she who is called the queen 
is the mother of the whole tribe. She is well taken care of, fed, and kept clean, and the eggs she lays are also the objects of watchful attention, but she has neither the freedom nor the power of any nember of her family, for she may not even come and go as do the others, or share in their delightful labors. The only laws ants obey are their own wishes; they do nothing because they feel obliged to do it.

The sense of duty- of forcing one's self to do or not to do some particular thing because it ought or ought not to be done-belongs only to mankind. But ants love to be busy, just as boys and girls love to exercise every musele in their limbs and bodies in healthgiving occupations; and they find plenty to do. First of all in importance in an ant-hill are the baby ants, for the whole life of the tribe depends on their well-being. While the little ones are yet in the egg they are constantly kept in the part of the formicary or ant nest best suited for hatching them.

In warm days they are brought near the surface, but during wet or chilly weather they are carried away to the deepest chambers. When they hatch they are without legs, and have to be constantly, so to speak, in the arms of their attendants. These baby ants are really what are generally taken for ants' eggs, when on disturbing a nest they are seen as their nurses hurry away with them in their mandibles or pinchers. The real eggs are very minute, and generally escape notice.

These babies, we are told, "are incessantly and carefully tended by their nurses, who clean them and 
feed them, carry them about during weather changes, escape with them or fight for them if attacked by enemies, and often show a species of attention that has an amusing resemblance to the dandling of an infant by a young mother. The ant children are often assorted according to age and size, reminding one of the class divisions in a schoolroom."

When these baby ants pass the second period of their existence, during which they are called larvæ, they either spin a whitish or light yellow cocoon (and it is sometimes these, as well as the larvæ, that are mistaken for ants' eggs), shutting themselves up in it, or else they sink into a deep sleep just as they are.

In doing this they enter upon the third stage of an ant's life, and are called pupæ, during which time they take no food. When they are ready to awaken again, which they do in the perfect and mature form of ants, the nurses, who have never left them a moment, know it, and help them out of their cocoons, and out of their old skins as well, and unfold their legs-you will remember they had none before-and smooth out the wings of the young queens and the male ants, that are the only kinds born with wings.

The winged ants do not delight in work as do the others, who are called workers. They are taken care of by the workers, looked after, fed, and cleaned like big babies. Sometimes they are free to go out of doors and run about a little, but are then carefully guarded, and not allowed far from the nest.

At last, however, a time comes when they must go away and seek their fortunes, nust be fathers and 
mothers of new tribes, and leave the home of their childhood, never again to return.

They are now old enough, wise enough, and strong enough to look out for themselves, and at the close of a warm day in the fall of the year they may be seen by thousands, swarming from the ant-hills and flying away.

When a young queen ant has found a place that pleases her for her future home, she breaks off her wings-for she will indulge in no future flightssettles down, and for a time works hard to make a little home for her children; she takes care of her own young, feeds them, cleans them, and brings up her first brood herself. When this is done her labors are ended; hereafter her children wait upon her and upon each other as long as she lives.

As for the male ants, they fly away on their travels, and never return to their old homes or make new ones.

\section{AGRICULTURAL ANTS. \\ HOW ANTS MANAGE A FARM.}

Among insects, bees and ants are without doubt the most skillful house-makers, and of these the latter approach nearest mankind in the construction of their dwellings. Indeed, if we can imagine a race of human beings building their houses partly underground, as do the tribes of northeastern Russia, and making them sufficiently large to accommodate whole com- 
munities of people, as do the puebla-builders of our Southwestern Territories, we would have in mind a state of things very much like that existing among the greater number of species of ants. In another respect also the ants approach very nearly to different races of human beings in different phases of human development; for, while some of these little creatures, like our North American Indians, live by hunting, others are pastoral-that is, have their flocks and herds, which they care for, defend, pasture, and shelter during the inclement part of the year; others, again, are agricultural-raising, cultivating, and harvesting crops of grain like farmers.

These farmers, or harresting ants, consist of numerous species found in the warmer countries of the world, but have been made the object of careful study, more particularly in Texas and Florida. Dr. Lincecum, the discoverer of the agricultural, or, as Dr. McCook calls it, the harvesting ant, has written an excellent description of the insect, an abstract of . which appears in the journal of an English entomological society for 1861 , and is as follows:

"The species which I have named agricultural is a large brownish ant. It dwells in what may be deemed paved cities, and, like a thrifty, diligent, provident farmer, makes suitable and timely arrangements for the changing seasons. It is, in short, endowerl with skill, ingenuity, and untiring patience, sufficient to enable it to contend with the varying exigencies which it may have to encounter in the life-conflict. 
"When it has selected a situation for its halitation, it bores a hole, around which it raises the surfnce three and sometimes six inches, forming a low, circular mound, having a very gentle inclination from the center to the onter horder, which on an average is three or four feet from the entrance. But if the

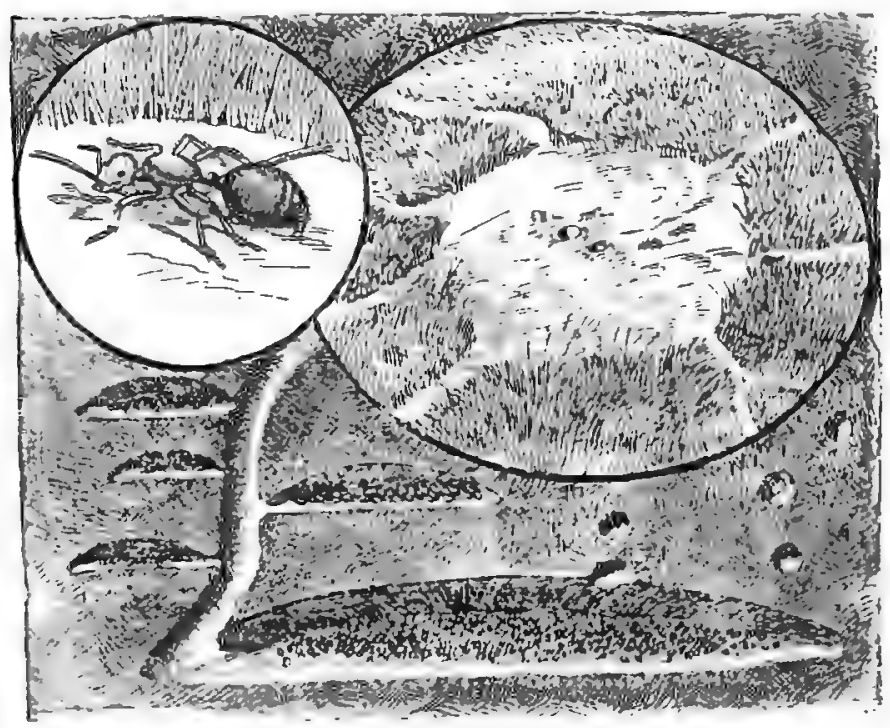

Agricuicural ant. Cleared spates, grumaries.

location is chosen on low, flat, wet land, liable to inundation, though the ground may be perfectly dry at the time the ant sets to work, it nevertheless elevates the mound in the form of a pretty sharp cone, to the height of fifteen or twenty inches or more, and makes the eatrance near the summit. In either case 
the ant clears the ground around the mound of all obstructions, and smooths and levels the surface to the distance of three or four feet from the gate of the city, giving the space the appearance of a handsome pavement-as it really is; within this paved area not a living thing is allowerl to grow except a single species of grain-bearing grass.

"Having planted this crop in a circle around and two or three feet from the center of the mound, the insect tends and cultivates it with constant care, cutting away all other grasses and weeds that may spring up among it, and all around outside the farm circle, to the extent of one or two feet more. The cultivated grass grows luxuriantly, and produces a crop of small, white, flinty seeds, which under the microscope very much resemble ordinary rice.

"When it is ripe it is carefully harvested, and carried by the workers, chaff and all, to the granary cells, where it is divested of the chaff and packed away. The chaff is taken out and thrown heyond the limits of the paved area.

"During protracted wet weather it sometimes happens that the provision stores become damp, and are liable to sprout and spoil. In this case, on the first fine day the ants bring out all the damp and damaged grain and expose it to the sun until it is dry, when they carry it back and pack array all the sound seeds, leaving those that had sprouted to waste."

Dr. Lincecum, who had at the time he made his discoveries public been studying these insects for twelve years, asserts that the ants plant as well as 
harvest their crops; but this is doubted by the Rev. Mr. McCook, who looked into the matter while on a visit to Texas.

The ants are not confined to their cultivated fields in gathering grain, but make long roads, which they keep quite clean and level, into the surrounding forests of wild grass, and on these little highways can be seen the busy harvesters going for and returning with the grain from distant harvest fields.

The pueblas or houses of the agricultural ant are many stories deep, and consist of a great number of chambers, granaries, and passageways or halls. Of course, there is no light or ventilation, which ants have learned to do without in these underground habitations. It is, in fact, the absolute need which human beings have for these two things that accounts for much of the difference between the habitations of primitive people and those of the lower animals; for whether it is beavers, moles, termites, or ants, they seem at times to do very well almost without either breathing or seeing. 


\section{CARPENTER ANTS.}

\section{HOW THEY BUILD THEIR HOUSES.}

If an old tree or stump or $\log$ in the woods is watched carefully during the warm weather months, little black heads may ofteu be seen thrust out from openings in or about the bark. Each of these beads belongs to a carpenter ant. The busy little creatures are bringing out the chippings left by the workmen

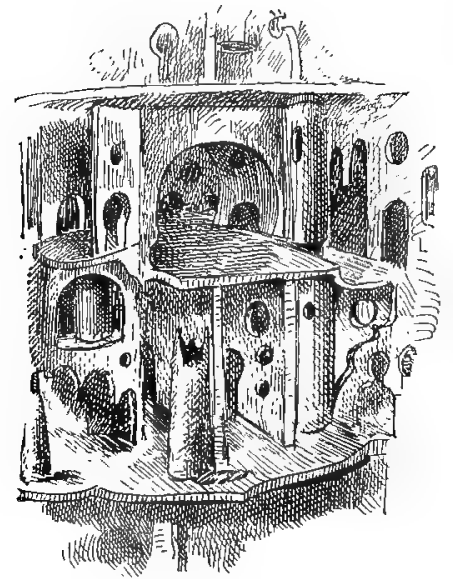

Interior of dwelling of carpenter ant. inside that are carving out rooms and galleries for the future use of the family. The chippings brought out are dropped to the earth beneath, and are taken by ants stationed below and carried off, to be dumped in some out-ofthe-way place.

The dwelling place, or formicary, as it is called, of these ants shows a series of floors laid out in small and large rooms and galleries, separated from each other by arches, pillars, and partitions. As ants can run up and down a perpendicular surface almost if not 
quite as easily as they can a horizontal one, they need no flights of stairs, nor do they greatly care to make their floors flat and even; and as it is always dark in the formicary, it is not necessary for appearance' sake to decorate the walls, or to finish their rooms with all the surfaces at exact right angles to each other, or plan their houses with the regularity of different parts that we find desirable in those we build. The doors opening from one room to another or upon the long galleries are either arched, or form more or less complete circles, ovals, or ellipses; and the same may be said of the windows that serve for ventilation in the partitions. Still, there is no real lack of symmetry in the construction of the habitation, when we take into consideration the purpose its architects had in view, and the admirable way in which it is adapted to the use of its tenants. The surfaces of the walls and floors are finished with the greatest care and kept scrupulously clean, and the galleries and doors are arranged to give the readiest and easiest possible access to all parts of the formicary.

A carpenter ant can not, like a human workman, lay aside his tools when he has done with them, for they are part of himself. Unlike those contrived by man, they are never dull or rusty, and no amount of invention can contrive any better fitted for the work they do. These mandibles, as they are called, attached by strong muscles to the face, are shaped something like the blades of a pair of shears, such as are used by sheep-shearers, but the inner edges are armed with sharp teeth. Never were more serv - 
iceable tools devised, or ones that could be put to a greater number of uses; for with them their owners dig, carve, saw, bore, pinch, carry and fight, and when used for each of these various purposes they seem as if designed for that particular end, and for. no other.

\section{HONEY ANTS AND THEIR HOMES.}

LIVING HONEY BOTTLES.

Honcy ants are small red insects, and are found throughout Mexico, Texas, and as far north as Colorado. Their nests are large, rounded mounds, or in some cases low heaps, extending over an area of perhaps twenty or thirty square feet. The ants, as a rule, nocturnal, working all night and sometimes by day, for they appear to be the most active and industrious of insects, even among races proverbial for industry; indeed, they seem to have no season of rest.

Of all the honwehold utensils used by living creatures, the oddest, without doubt, are the living bottles of the honey ant. The insects, as their name implies, live upon honey, or sweet, sirupy fluid from plants; but although ants are intelligent enough as builders, ' and shepherds or cattle-keepers, and as farmers, they have never learned from their cousins the bees to make vessels in which liquid can be stored, and the question arises how their food is to be kept after it is 
collected. The honey ant overcomes the difficulty in a decidedly novel and interesting manner. Certain of the ants of a larger growth than the others are utilized as receptacles for the honey-food supply, and become literally honey bottles, the liquid food being forced by the workers into the crop of the living

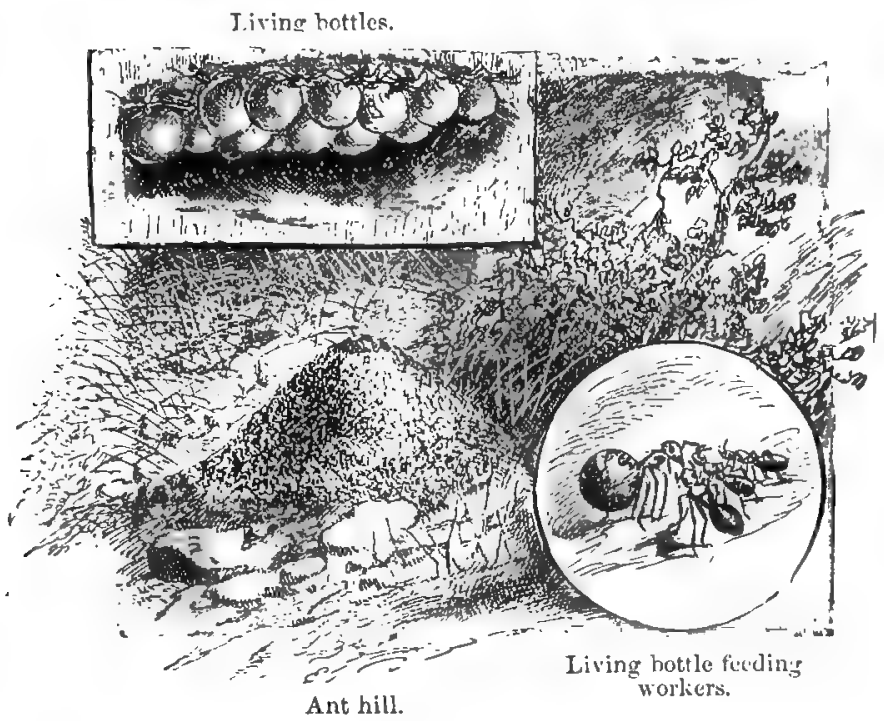

bottle, until the ant resembles an amber-colored currant or berry with a small stem, consisting of the head and thorax or fore part of the body with the legs of the insect.

The honey-bearers are rendered practically helpless by the operation, but are carefully attended by their companions. They are kept in chambers built for the 
purpose, about six inches long by four in height. Here they cling to the ceiling of the apartment, their distended crops hanging downward like clusters of small grapes.

The small workers forage among the trees in the neighborhood for food; and tind it in what are known as galls-curious enlargements of growths on plants formed by insects in depositing their eggs in the wood, the latter growing about it, and allowing the escape of a liquid that is greatly esteemed by ants, and certainly tastes like honey. Filling their bodies with this material, the workers proceed to the storeroom and deliver it up to the honey-bearers, who retain it until it is needed; for when the other ants desire their rations they go to the dark chamber and are forthwith supplied with all they want.

The bodies of the honey-bearers are eridently formed by Nature for the purpose, being covered with plates that spread apart when the portion of the body they cover is distended.

Not only do the honey bottles furnish food for their brothers and sisters, but also for human beings. They are used as desserts, as we use grapes or curl'ints, by the natives of New Mexico. A plate of these ants is set before a guest, who by a pressure of the distended sac between the teeth extracts the honey. 


\section{HUMAN CLIFF-DWELLERS.}

WHO THEY WERE AND HOW THEY LIVED.

Scarcely more than four hundred years ago America had not a name. Neither the old Vikings, who visited its shores long before Columbus made lis first voyage, nor John Cabot, who first looked upon the continent after the Northmen, had any idea of the nature or extent of their discoveries.

When it was ascertained that two great continents on this hemisphere balanced Europe, Asia, and Africa on the other, America began to be called the New World. But it is not in reality new. It is quite as old if not older than that on the other side of the globe. Ages before it was known to Europe, successive civilizations arose, flourished, and decayed; and, as far as anything is actually known on the subject, it is just as possible that the Old World was discovered ages and ages ago, and peopled from America, as that the native inhabitants of our hemisphere, the forefathers of our Indians, came from the Eastern hemisphere, for America is a very aucient land. Of course, no one thinks that this is the case, but really nothing at all is known about it.

Many, many centuries there lived a race of peaceful Indians in that part of our country now divided into the States and Territories of Arizona, New Mexico, and Colorado. Instead of warring upon the 
SS CURIOUS HOMES AND TIIEIR TENANTS.

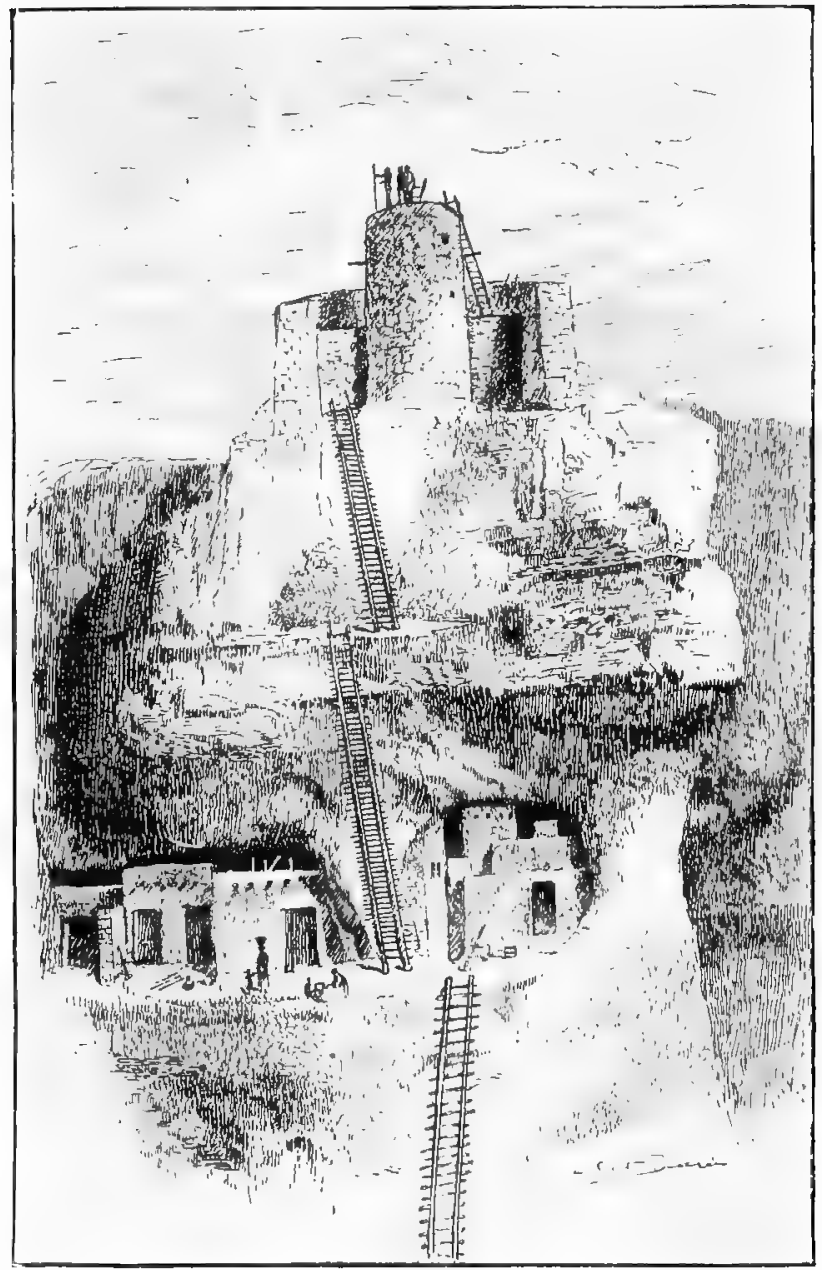

Clitt-dwellinus. 
neighboring tribes and depending upon hunting wild animals for food, they cultivated great tracts of country, and raised maize and beans and other crops, upon which they chiefly lived. They wove cloth, and made baskets and excellent pottery, beautifully colored and decorated. Their houses, in time of peace, were in the bottom lands. They consisted of pueblas - that is, as has been explained in the introduction of this little book, towns consisting, as do those of the white ant and other insects, of a single structure, just as large apartment houses contain many distinct habitations. These great buildings have ground plans of various shapes,

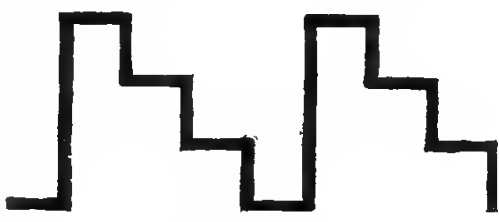

Puebla ornament. the most usual being an oblong quadrangle, three sides of which are occupied by the building, and the fourth, one of the longer sides, is inclosed by a wall or a row of single rooms. Sometimes the front wall is curved outward, and there is one case in which the whole structure is in the shape of an ellipse.

The general structure of these buildings is unlike any found in the Eastern hemisphere. It is, indeed, so characteristic of the aboriginal inhabitants of America that it is perpetuated in an ornament peculiar to the native writers of this country, called the puebla ornament, consisting, as is here shown, of a succession of steps, which is a very good plan of a sec- 
tion of a puebla building. Suppose, for instance, the puebla to be three stories high and three deep. The outer walls will be three stories high, but the top story only one room deep, the second story two rooms deep, and the first story three rooms deep. Seen from the country behind it, the building will

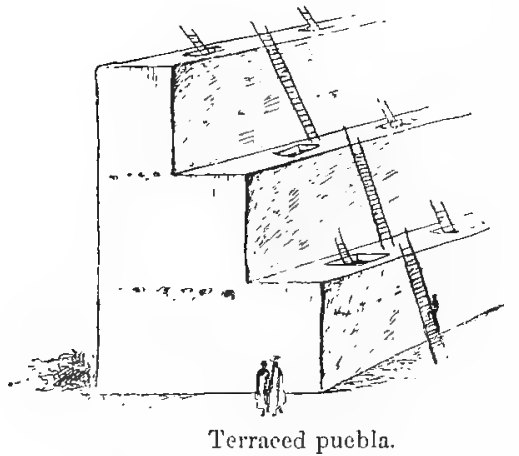
look like a house with perpendicular walls, but seen from the courtyard it appears terraced. The doors were in the ceilings of the rooms and were entered from above by means of ladders, the dwellers in the top stories having to go up three ladders and over the roofs of each of the lower tiers.

Some of the pueblas are five hundred feet long, and contain hundreds of rooms.

But besides these pueblas, the people who lived in them had their cities of refuge high up in caverns in the side of inaccessible cliffs, where they built the most wonderful habitations, perhaps, in the known world. The part of the country in which these ruins are found is now very desolate, for the time when they were built is so very long ago that a radical change of climate has taken place, and where great fields of waving corn once grew, scarcely a living plant appears.

In southern Colorado rises the river San Juan. 
North of this the river Dolero begins in the San Miguel Mountains, and flowing west and north at last joins the Rio Grande. It is in the upper courses of the two former rivers that the ruined cliff-dwellings are found. The mountains tower to the height of fourteen thousand feet, bare and bleak. Instead of the smiling river valleys of the eastern part of the continent, there are deep, gloomy ravines called cañons, worn down from the surface of the ground to a depth of from five hundred to two thousand feet, often so narrow that a ray of sunshine seldom or never penetrates their shadowy recesses. A few cottonwood trees are dotted along these cañons, and at intervals, where they widen out, a patch of scanty wire grass tinges the gravelly soil a faint green. Above is a desert waste of sand and sagebrush and stunted greasewood, peopled only by rattlesnakes, horned toads, and tarantulas. Patches of white alkali on the sand look like snow, but the sun beats down upon the dry earth with pitiless fury.

It would be, indeed, hard to believe, in the absence of the ruined habitations to be found on every side, that this dreary land was once thronged with semicivilized races; but along the terraced faces of the more open cañons cluster multitudes of picturesque ruins, in the valleys the remains of pueblas, and in the wilder ravines may be seen single habitations, perched like the nests of the cliff swallow upon the face of the perpendicular precipices. Here the peaceful tillers of the soil retreated when attacked by predatory tribes, and here remained, living upon the 


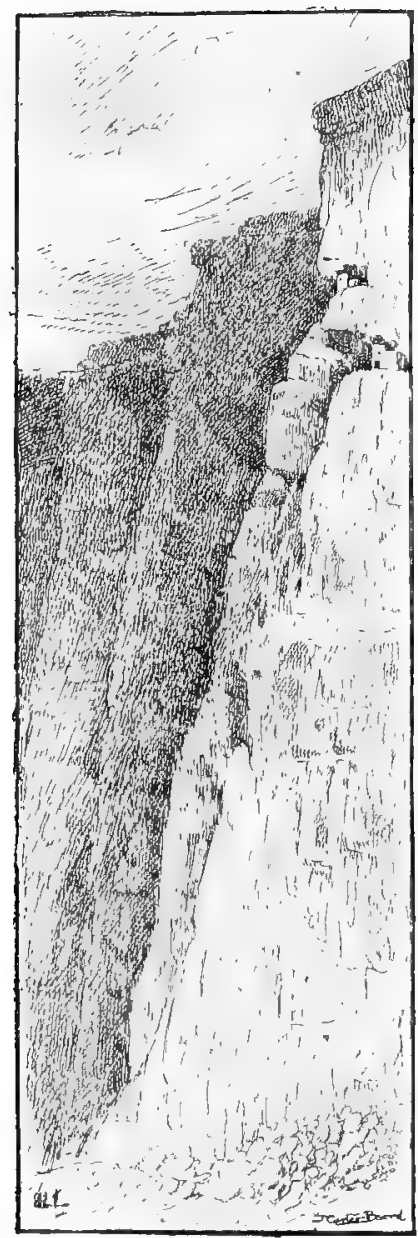

Position of cliff-dwellings. provisions stored up for such occasions until their enemies saw tit to leave them in peace.

Fully a thousand feet above the Rio Mancos are single houses, groups of two and three, and villages, according to the width of the terrace upon which they are built. They are so high that to an obserrer at the foot of the cliff they look like mere specks. It is impossible to reach then from above on account of overlianging rocks, and there is no present way of gaining access to them from below, although the remains of pathways in the rocks show it was once possible to ascend it.

The labor of carrying material for these builclings, and provisions and water up the steep face of the cliff can scarcely 
be estimated. Some of the cliff-houses are of considerable size. One is mentioned several hundred feet above the Rio de Chelly, tive hundred and fifty feet long, three stories high, containing seventy-six rooms on the ground floor. The walls were plastered with white cement. The prints of the human hands that uncounted centuries ago spread it upon the walls may be still seen. Near the floor are the impressions of the chubby palms of little children, every crease and dimple being perfectly preserved.

It has been ascertained that these people were fireworshipers. However small the niche in the rocks in which their houses were crowded, there was always room left for a circular building, called an estufa, in which the sacred fire was kept burning.

"It is said," writes Mr. Davies, in his Conquest of New Mexico, "that Montezuma kindled sacred fire in the estufas, and commanded that they be kept burning until his return. He was expected to appear with the rising sun, and every morning the inhabitants ascended to the housetops and strained their eyes looking to the east for the appearance of their deliverer and king. The task of watching the sacred fires was assigned to the warriors, who served by turns a period of two days and two nights without eating or drinking. 


\section{AUSTRALIAN CLIFF-DWELLERS.}

\section{A NOISY MULTITUDE.}

The cliff-dwellers of Australia consist of flocks of great white cockatoos. Certain precipices near South Australian rivers are the homes of innumerable cockatoos, just as the cliffs of the North Sea are the resort of thousands of sea gulls. The rocks are completely honeycombed by them. In each of the multitude of cockatoo nests lay two pointed white eggs the size of those of a bantam fowl, and in time the nestlings issue forth with the mother bird from the hole in which their nest is placed to add their voices to the chorus of triumphant cries above, below, and on every side. The combined shrieks of the multitudes of birds here assembled are perfectly appalling, and can only be faintly imagined by those familiar with the yells that a few captive cockatoos are capable of producing.

There is not much chance of raising fruit or crops of any kind where these birds abound. They waste much more than they devour, and it is almost impossible to drive them from the fields. They have sentinels posted to guard evcry approach, and the moment the distant coming of an enemy is seen the sentinels ntter a subdued cry, and the field that was before alive with the clamor of the birds is as still as death. In a moment every cockatoo has hidden. 
itself amid the grain and is making the best of its way to the part of the field most remote from that where danger threatens; and having run as far as suits their purpose the whole flock rises in the air and disappear in the nearest forest, only to return as soon as the intruder, whose presence drove them away, absents himself.

"Perhaps," writes Captain Grey, "it would be impossible to imagine a more exciting spectacle than that of the Australians hunting the cockatoo. They employ for this purpose the very remarkable weapon peculiar to this people, the boomerang, which, as the reader probably knows, is a sickleshaped flat piece of wood, which can be thrown by the hand a distance of one hundred feet, and flies in small circles with many windings from the direct track. An Australian will follow a flock either into the fields or woods, preferring, however, places where large trees are situated near water, such spots as these being the favorite resorts of cockatoos. Here they are to be found in innumerable hosts, climbing on the branches or flying from tree to tree; here also they sleep, and here the wily native comes, most watchfully observing all necessary precautions. He goes from one tree to another, and creeps from bush to bush, taking great care not to disturb the wary birds, but in vain; for, however quiet his movements may be, he is soon discovered, and his near approach greeted with a hideous cry; the birds have already perceived that danger is near, although they do not know what the next step may be. 
"At length their pursuer reaches the water and discloses his dark form to their view. Amid piercing shrieks the white clond of birds rises in the air, and at the same moment the Australian launches his weapon among them. The boomerang, which was thrown with great force, dances and springs in the most wonderful manner over the water, and then, rising higher and higher in its wayward flight, is soon careering in the midst of the frightened flocks. A second, a third, and a fourth weapon are discharged; in vain the terrified creatures attempt to escape; the apparent aimless course of the missile bewilders and delays their tlight. One after the other is struck by the boomerang and comes fluttering to the ground, knocked senseless or with broken wing, screaming with pain and terror; and it is not until the dusky hunter has attained his end that the remainder of the terrified flock hide themselves in the foliage of the trees."

The Australians eat the bird ; and although a native Australian will eat almost anything, the flesh of a cockatoo is really tolerably good, and the soup made from it is excellent.

The great number of these birds that are exported to every part of the civilized world proves that they are not difficult to capture or keep, for, if properly fed and cared for, they will live a very long time in captivity.

A cockatoo can be tanght to speak pretty well, though, of course, is never as teachable as true parrots; it becomes very tame, and if kindly and gently 
treated develops a mild and gentle disposition, but it never forgives insult or harsh treatment. It has an excellent memory, and will avenge, if it can, an injury years after receiving it.

\section{EAGLES' NESTS,}

AND THEIR BABIES.

Eaglets are not as cunning and pretty as little chickens or ducks. It is true, they are covered all over with a handsome coat of soft, velvety, strawcolored down, but their heads seem much too big for their bodies, and as for their feet they are so large and heary that the young birds can not stand or walk upon them. Even when they are very young their eyes are sharp and fierce, and so are their crooked beaks, always ready to snap at any fish or meat that cornes in their way.

Baby eagles are very greedy indeed, and never seem to have enough to eat. The eggs from which they are hatched are the size of a rather small hen's egg, about two inches long, but they are not shaped like biddy's eggs: they are as round as baseballs, and rough to the touch on the outside.

The nest which the papa and mamma eagle builds is very large and strong. It sometimes measures six feet or more across, and from four to five feet in thickness. It is not always hollowed out, as are the nests of most other birds, but is flat on the top like 
a table. One would think the little birds would fall from such a nest, but they never seem to do so until they are old enough to fly.

The eggrs are sometimes laid in extremely cold weather, when the thermometer is many degrees below zero, but neither the eggs nor the little birds hatched from them ever freeze. The parent's warm breast keep both from chilling, and the little birds are soon hardy enough not to mind the cold at all; neither do they dread hot weatler, but thrive as well far south in Florida and Texas, and even under the blazing sun in Mexico, as they do in the cold north.

The nestlings of the common eagle, which is the kind now mentioned, weigh about two pounds. This is a pretty good weight for a baby bird, though they are much heavier when the down of the little birds has given place to feathers, and the mamma and papa eagles begin to teach their little ones to fly.

Sometimes there is but a single nestling in the great nest, sometimes two, but seldom more than two, so that the little birds have all the care and food that are usually shared among other birds by a large family. The parent birds seem to pay a great deal of attention to the education of their children. Sir Humplury Davy had an opportunity of seeing the instructions given, and I shall give his account in nearly his own words. He says:

"I once saw a rery interesting sight above one of the crags of Ben Nevis, Scotland, as I was going in pursuit of black game (the blackcock, a game bird in Scotland). Two parent eagles were teaching their 
offspring, two young birds, the maneuvers of flight. They began by rising from the mountain in the eye of the sun.

"It was about midday, and bright for this climate. They at first made small circles, and the small birds imitated them. The older birds paused on their wings, waiting until their children had completed their flight, and then they took a second and larger circle, always rising toward the sun and enlarging their circle of flight, so as to make a gradually ascending spiral. The young ones slowly followed, apparently flying better as they mounted; and they continued this exercise until they became mere points in the air, and the young ones were lost, and afterward the parents, to our aching sight."

Eagles do not have different mates every season, as do birds generally; they pair for life, and sometimes occupy the same nest for many years.

But though faithful to their young and to each other, eagles are tyrants and robbers to all other birds. Not only do they prey upon birds and animals sinaller and weaker than themselves, but they rob other birds of their prey. Sitting upon some lofty crag or tree, the eagle watches the birds flying above the waters of some lake or sea. High above all soars the fishhawk. As the eagle catches sight of him his fierce eyes flash, and balancing himself upon his perch he half opens his wings to be ready for instant flight. Down, swift as an arrow, plunges the bird he watches into the water, from which he appears with a struggling fish in his beak, which he is about to 
carry away for his breakfast. As he sees this the eagle screams with joy, and, bending his neck and spreading lis broad wings, he instantly gives chase to the feathered fisherman. Each tries to mount above the other, but the eagle, having no heavy fish to carry and possessing more powerful wings, is the victor. Just as he is about to reach the fishbawk, that poor bird with a scream of despair and anger drops the fish he carried in his beak. The eagle, poising himself for a more certain aim, descends like lightning upon it, catches it before it reaches the water, and carries it silently away to its nestlings in the woods." This, put in more simple language, is what Wilson, a great American naturalist, tells of the way in which the parent eagle provides food for his young ones.

One of the most wonderful things about eagles is their power of vision. Their eyes are much better and stronger than ours, and they bear not only to look upon the sun, but they can see much more distinctly than we can. Even baby eagles can see their parents at immense distances coming to feed them, as they plainly show by their cries, before a human eye can possibly make them out in the clearest light.

If an eagle is taken from the nest of the parent bird and brought up by hand it becomes very tame, and makes an interesting pet, though not exactly of the kind one would care to have about the house. 


\section{TREE HOUSES.}

PEOPLE THAT USE LADDERS TO CLIMB UP TO THEIR BEDS IN THE BRANCHES.

The natives of New Guinea climb like monkeys and travel long distances from one tree to another, without descending to the ground. In this country, where birds build little fairylike cabins on the ground, the people construct their houses in the tops of the tallest forest trees. First, a native having climbed the great trunk of the teak or cedar or oak tree he has selected, begins by cutting off some of the branches the right length to support a platform of bamboo on which his house is to rest.

You would wonder how he could do anything with the tools he uses, if you should see them. He has no saw or steel-edged axe, but only a sort of tomahawk made of stone, and knives of bone or hard wood. When, however, he lias in some way managed to get the limbs of his tree so cut and fashioned as to support his house, his hardest work is done.

The house itself is soon built, and is made of bamboo strips and thatched with palm leaves. All parts are firmly lashed together with strips of rattan palm, a very tough vine used by the natives in place of ropes. It is not a large house, though it sometimes contains several rooms, but it is a safe and secure retreat for the women and children in case of sudden attack by hostile tribes. 


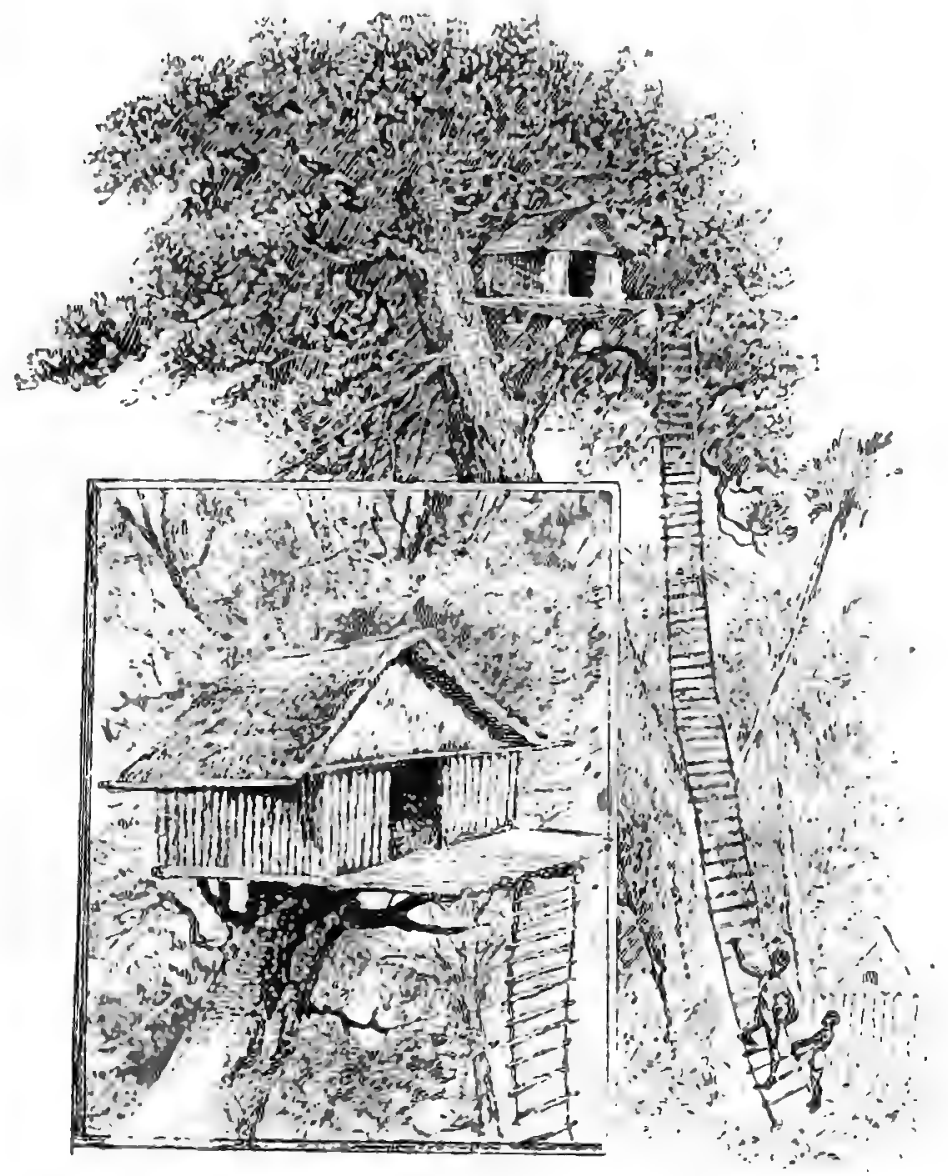

Tree housea. 
But as the builder can scarcely expect his wife and little children, to say nothing of his pet pigs, of which these people generally keep one or more with them in the house, to climb the tree, he has to provide some way of getting them from the ground to the house. This he does by making a long ladder of vines reaching from the earth to the platform upon which his house is built. If enenies appear, the ladder is of course drawn up, and those above rest securely, far out of reach of any weapon known to the wild men of New Guinea. These tree houses also serve for lookouts from which to see coming friends or enemies in time to prepare a suitable reception for either.

There are several good reasons for building houses so far above the ground besides those already given: one is, that they are not reached by the low-lying bad air that in this country causes fevers and sickness; another, that they are free from ants and mosquitoes, two terrible plagues throughout New Guinea; and still another is, that the breeze that gently rocks the house, like a bird's nest in the treetops, is much pleasanter and more refreshing than the sultry heats below.

If you should climb the long ladder and peep in at the door, you would find the family perhaps all asleep, or sitting about on the floor eating yams, cocoanuts, or bananas, and sharing them with their pet pigs, parrots, or poultry. You would find there no pictures, toys, or playthings, such as even the poorest children among us possess; no music and no books; 


\section{CURIOUS IIOMES AND THEIR TENANTS.}

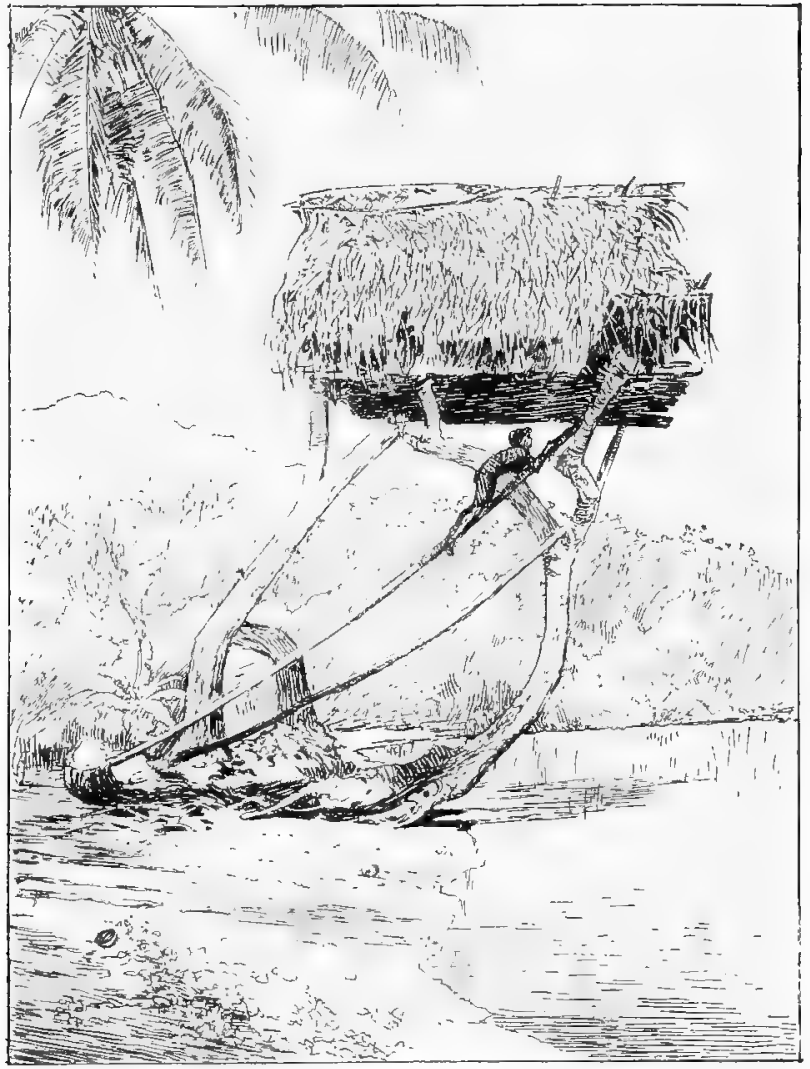

Fisherman's dwolling, New Guinea.

no furniture in the room, not even a bed, and no mats on the floor.

Many a tree-built nest is constructed with more art, and is more comfortable for the little ones who 
are born in it, and is far prettier, than the rude huts of the wild men of New Guinea.

\section{A STRANGE ANIMAL.}

\section{A LITTLE HOBGOBLIN.}

Sometimes in the dusk of the evening there suddenly appears to the people in some parts of Java remarkable dwarfish beings which they call malmags, or hobgoblins, because they look more like the creatures of a disordered imagination than any real, living animals; and so impressed are those who see them, we are assured, with the uncanny apparitions and the malevolent influence they are supposed to exert, that if one is seen on a tree near their rice grounds the plantation is abandoned and left uncultivated. And yet these terrible animals are no larger than squirrels, and are as harmless as possible.

It mnst, however, be confessed that it would be difficult to imagine anything more weird, uncanny, and goblinlike than are these malmags or specters. The creature, when seen, fixes a pair of enormous yellow eyes upon the observer, erects his grotesque figure, and begins making the most extraordinary leaps several feet directly up into the air.

It is not by any means a common animal eren in the countries it inhabits-the Oriental Archipelago and the Philippine Islands. It makes its nest and 


\section{CURIOUS HOMES AND THEIR TENANTS.}

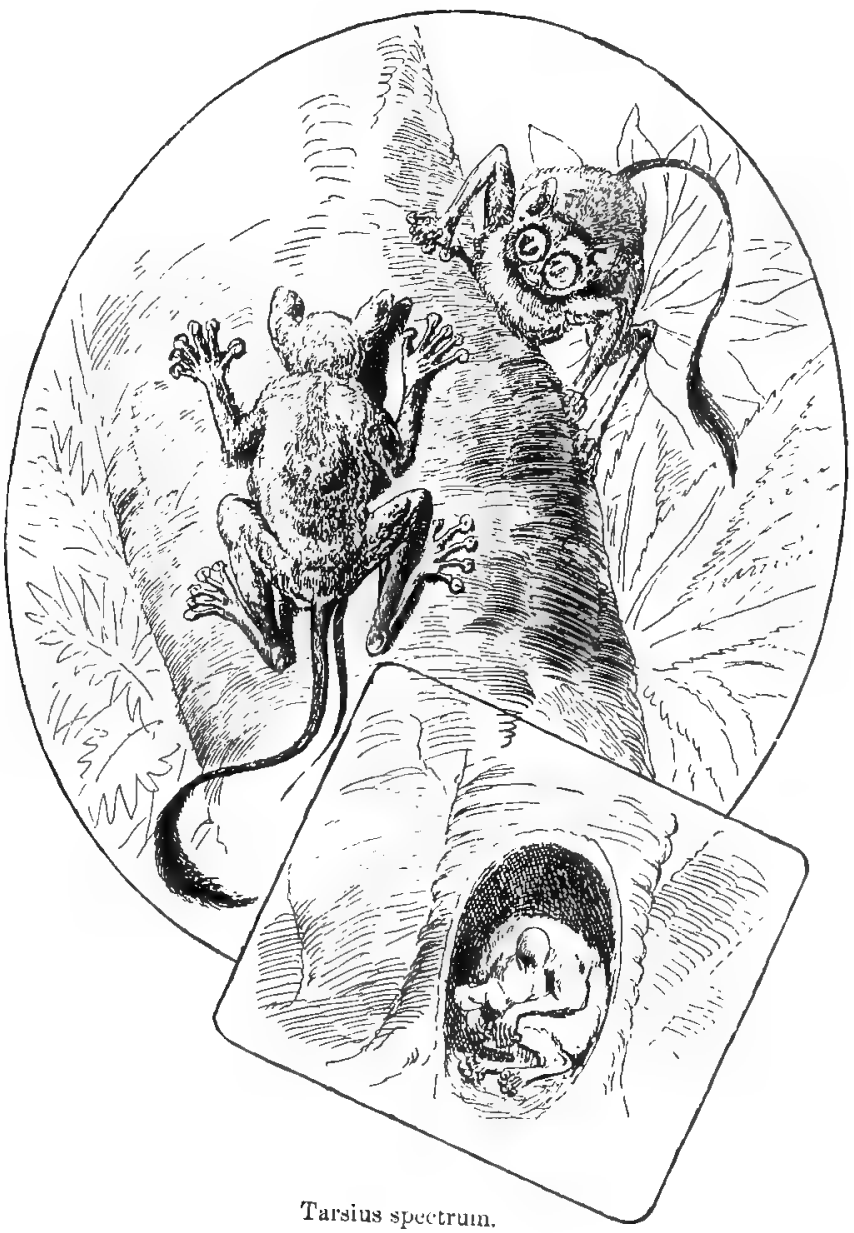


rears its young in the hollow roots of the great bamboos that grow in these countries.

None have ever been brought alive to Enrope or America. Don Guillemard, who had a living specimen when he was at Celebes, in the Malay Archipelago, writes :

"The most interesting" addition to our menagerie was a tiny Tarsius spectmum, brought to us by a native, by whom it was said to have been caught on the mainland. These little creatures, which live in trees and go about at night, are nearly the size of a small rat, and are covered with remarkably thick fur, which is very soft. The tail is very long and covered with hair at the root and tip, while the middle portion of it is nearly bare. The eyes are enormous, and indeed seem, with the equally large ears, to constitute the greater part of the face, for the jaw and nose are very small indeed, and the latter is set on, like that of a pug dog, almost at a right angle to the forehead. The hind limbs at once attract attention from the great length of the ankle bones, and the hands are equally extraordinary from their length, the curious claws with which they are provided, and the remarkable pads, like those on the toes of a treetoad, at the ends of its fingers, which probably enable the animal to retain its hold in any position.

"This weird-looking creature we were unable to keep long in captivity, for we could not get it to eat the cockroaches which were almost the only food we could obtain for it. It remained quiet by day in its darkened cage, but at night, especially if disturbed, it 
would spring vertically upward in an odd, mechanical manner, not unlike the hopping of a flea. On the third day it found a grave in a pickle bottle."

\section{ANIMALS THAT SLEEP THROUGH THE WINTER,}

AND ANIMALS THAT SLEEP THROUGH THE SUMMER.

Every animal inhabiting the colder regions of the earth is taught by instinct how to avoid the severity of winter. Birds, of course, take the air line for regions nearer the equator, and in a few days have exchanged arctic or antarctic storms for lands where "summer sings and never dies"; but mammals who can never quit the regions in which they are born either seek out holes and caverns and remain there, living upon such stores of provisions as, taught by the same instinct, or, in other words, by their Creator, they have collected during the milder season of the year, or sink into a deep sleep and a long one-so long, in fact, that they do not arise for many months, until Spring visits their abode again and awakons them with the wirmth of her perfumed breath.

During this sleep, life, reduced to its lowest ebb, is scarcely to be detected in the feeble pulsations of the heart, and breathing so slow that through months of this deathlike sleep the breath is drawn less frequently than during a couple of days of active waking life; and the fat which the abundance of summer has 
enabled the animal to gather suffices to keep up the glimmering spark of life. The warmth of the body sinks to a few degrees above the freezing point; the limbs stiffen and become almost insensible to injury.

This, however, is not true of all animals exposed to the same degree of temperature; and why some should hibernate, as it is called, and others should not, is no more known than that some hibernate in winter and others in summer-though, to be sure, "hibernate" is scarcely the right word to use in the latter case, since the Latin word from which it is derived means winter. Many of the smaller mammals as well as reptiles and insects in Europe and America pass the colder part of the year in this way. Like the water rat, they sleep.

"When the cold weather comes and the water plants die, And his little brooks yield him no further supply,

Down into his burrow he cozily creeps,

And quietly through the long winter-time sleeps."

But to find those that take these long naps in the hot season we must go to the tropics.

In Madagascar, where the weather is always very warm, there is, as in most hot climates, a wet and a dry season. There are numbers of little busy, tailed creatures that sleep for many weeks during the hottest part of the year in nests of twigs and leaves that they have, birclike, built in the trees. They belong to the lemur tribes, and are called dwarf lemurs or mouse lemurs, or cheirogales, which last name is from two Greek words, and means "with hands like a weasel." These little animals which are not so large as a rat, de- 
vote their waking hours during the wet season, when the warm rains make everything grow in the greatest profusion, to the cultivation of their long tails. It is true, their bodies grow sleek and fat, but their tails increase in size out of all proportion. During the time, however, of their summer sleep their beautiful tails grow more and more slender, until when they again awaken their appearance is so changed that they would scarcely be known for the same animals. They are, however, principally known as the best nest-builders among the mammals; and their nests, like those of birds, are not used alone as sleeping places, but homes for their young until the little ones are old enough to look out for themselves.

They, like most lemurs, are night animals, and their eyes shine in the dark like illuminated jewcls.

\section{POTTO.}

HOW HE WAS BROUGHT TO ENGLAND.

A gentleman named Bartlett, while on a voyage to the $A$ frican const, obtained a strange animal which he called "Van Bosman's potto," because nearly two hundred years ago a ship captain named Van Bosman, who visited the Guinea shore, saw one of the queer little creatures, called it a potto, and wrote an account of it after reacling his home in Holland.

When Mr. Bartlett first took the potto aboard his ship it was so young that he feared it would not live. 
As the ship upon which he had embarked for England left the warm climate of Africa and met chilling breezes from the north, Mr. Bartlett saw that his little charge suffered from the cold, and tried to think of some way to keep him warm and comfortable. After trying various plans without much success, an old nursery rhyme he had heard when a child occurred to him:

By Baby Bunting,

Papa's gone a-hunting,

To get a little rabbic skin

To wrap his Baby Bunting in.

"Just the thing!" said Mr. Bartlett, and straightway he had a cunning little bag made of hare skins with the fur inside. In this snug nest potto slept most of the time, and, in order to make sure he was warm enough, a baby dog, older than potto, was put into the bag to keep him company. When the puppy had to go to its mother, another was put in its place. Potto clung to the puppies as closely as he would have clung to a mother if he had had one, hugging them so tightly that the doggies did not quite like it. This nursing, however, did well, and potto grew strong and healthy, and was, on the whole, good tempered. He slept all day perched on a door, but at night he would come down and wander about the room. He would not eat bread and milk, but would feed on pineapples and bananas and water. Although there were often insects in the room, which had flown in at the window, potto would not touch them, but one day he was found busy dining on a tray of preserved beetles. 
In its own home in West Africa and the coasts of the Gulf of Guinea the white people who live there call the potto a bush dog, and the natives, who for some reason are very much afraid of it, call it aynso. They seem to have an idea that it will jump upon them and cling so tightly as to choke them to death, or else, like the Old Man of the Sea in the story of Sindbad the Sailor, will clasp its victim with its hind legs in such a manner that the person attacked can never get rid of his living burden, but must carry it about with him for the rest of his natural life.

Although called a dog, the potto looks much more like a monkey; but he really belongs to a solemn, sedate, sober, slow-going set, very different from the merry, mischief-loving monkeys. He seems to be bowed down with grief and trouble and to have a world of care on his shoulders. Never is he seen playing pranks or rushing noisily about, but always secretly and silently stealing from one place to another, or sitting motionless in the strangest postures, fast asleep.

All these little creature live in nests built in the hollows of forest trees or anong the branches. They move about noiselessly, and never show themselves at all during the day, so that they are very seldom seen even by the natives. They belong to a family of animals called lemurs, which means "ghosts," because of their sly, quiet ways, and because they only appear at night. 


\section{BASHFUL BILLY,}

HIS WAYS AND HABITS.

Bashful Billy is a slow loris, a strange, awkwardlooking little creature, and certainly slow enough to deserve the name. He was taken from his nest in a hollow tree in Java when he was very young, and has been brought up as a pet by the lady to whom he belongs. He might be taken for a monkey but for his soft, slow ways and the unmeaning stare of his great, yellow, owl-like eyes. When he sleeps-which, it must be confessed, he does most of the time-it does not seem to make the least difference to him whether he hangs head downward, like a bat, from the top of his cage, or clings to its side with all four of his paws, or doubles down until the top of his head rests on the cage floor, or curls up like pussy, provided that his nap is not disturbed. If, however, he is awakened he gets quite out of temper, and will show any one who doubts it that he has very sharp teeth, though in truth he is very good natured at all other times.

He has to be bathed every week in warm water, and when he is taken out and dried he licks himself all over like a cat. He seems to dread dirt, either in his cage or upon his person, as much as the most careful housewife. He is very fond of fruit, especially bananas, but will not touch peaches, perhaps 


\section{CURIOUS HOMES AND THEIR TENANTS.}

because the woolly fuzz on the skin is not pleasant to the touch. He will eat almost any kind of insect, or bits of raw meat from the breast of a chicken, but cooked meat he does not like. Roaches are his favorite food, and he has almost cleared the house of them.

When the evening brings in his daytime he is wide awake and very gentle, though never playful. He will take the finger of his mistress in his paws, convey it to his mouth, and lick the tip end of it with his tongue, but he never at this time of day offers to bite. On cold, wet days he is much crosser and more out of temper than in warm, sunshiny weather.

There is something very peculiar in his way of closing his eyes, for, instead of bringing down the eyelid over them as other mammals do, the lids come together in a slanting direction, outward and inward. He will sometimes rise up and stand erect like a little man, or some kind of a queer goblin from fairyland, for which, indeed, he was taken ly the housemaid when she first caught sight of him.

The loris is not a rare animal in the countries from which it comes - that is, in India, Cochin-China, the Maliy Archipelago, and the great islands of Java, Borneo, and Sumatra; but as it is always hidden away during the daytime in its nest, which it builds in hollow trees, and as it goes abroad in search of food only at night, it is very seldom seen. 


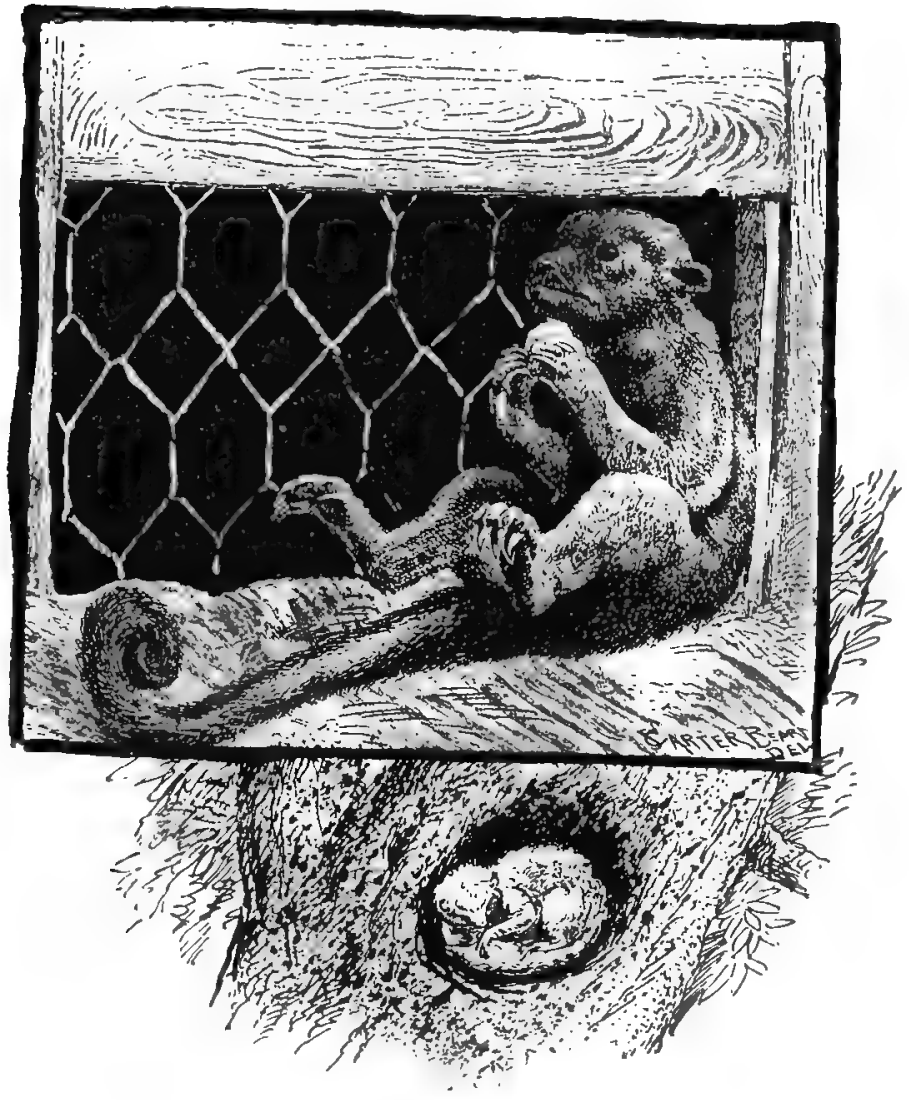

THE LONG-TAILED COONBEAR, OR KINKAJOU.

\section{A QUEER PET.}

The kinkajou has a tail nearly twice as long as his body and almost as thick. When he wishes to take a nap he goes to the hollow in the tree he lives in, 


\section{CURIOUS HOMES AND THEIR TENANTS.}

makes a coil of his tail and goes to sleep upon it; it is his bed; it is also an extra limb, for he can coil it about the branch of a tree, or any support small enough in circumference to allow it to go once or twice around and hang suspended in mid-air. Like the tail of an opossum, that of the kinkajou is prehensile. The little fellow takes great pride in his long, furry tail, and spends much of his time dressing and combing it with his tingers. He uses his hands much as does a raccoon or monkey, and, sitting upon his tail, holds a bit of bread in one paw while he breaks off bits with the other, and also, like a monkey, uses both his fore and hind paws to carry food to his mouth. He is very fond of bananas, apples, and the like.

One that I have often seen, owned by a lady in New York, would not touch animal food, though in their native state we are told the kinkajou lives upon birds, insects, and lizards, as well as fruit. He makes a charming pet, gentle, quaint, clean in his habits, and is an intelligent as well as an affectionate animal. 
A TENEMENT HOUSE BUILT BY BIRDS. 117

\section{A TENEMENT HOUSE BUILT BY BIRDS.}

HOW THEY BUILD IT.

An oriole's nest, hanging over the little bracket upon which is placed my miniature bust of Audubon, is an unfailing source of interest and delight to me. With what a wise provision the birds have suspended their home on the frail and flexible branchlets at the extreme end of a bough, out of harm's way; and with what untaught skill have they woven the most refractory and unpromising substances into a beautiful and compact tissue, while their unerring instinct has determined the proper size of the structure, with just enough for its needs, and not a fraction of an inch to spare!

What selection and adaptation of material are here represented! Everything has had to be found and fitted. The twig that is so deftly carried about the nest to frame and strengthen it is perhaps the only one among a thousand that has exactly the needed shape and curvature. The bit of birch bark with just the proper warp to protect the lower part of the nest has been chosen with as much care as that bestowed by an Indian in the selection of a piece of the same bark for his canoe; and, indeed, every small fiber, straw, and hair, or bit of moss, has been made the subject of such serious and painstaking deliberation that I can find no imperfection in the wonderful economy of space and material used. 


\section{CURIOUS HOMES AND THEIR TENANTS.}

And yet this is but a simple structure compared with those of some of the tropical orioles, which in turn must yield the palm for excellence to the nests

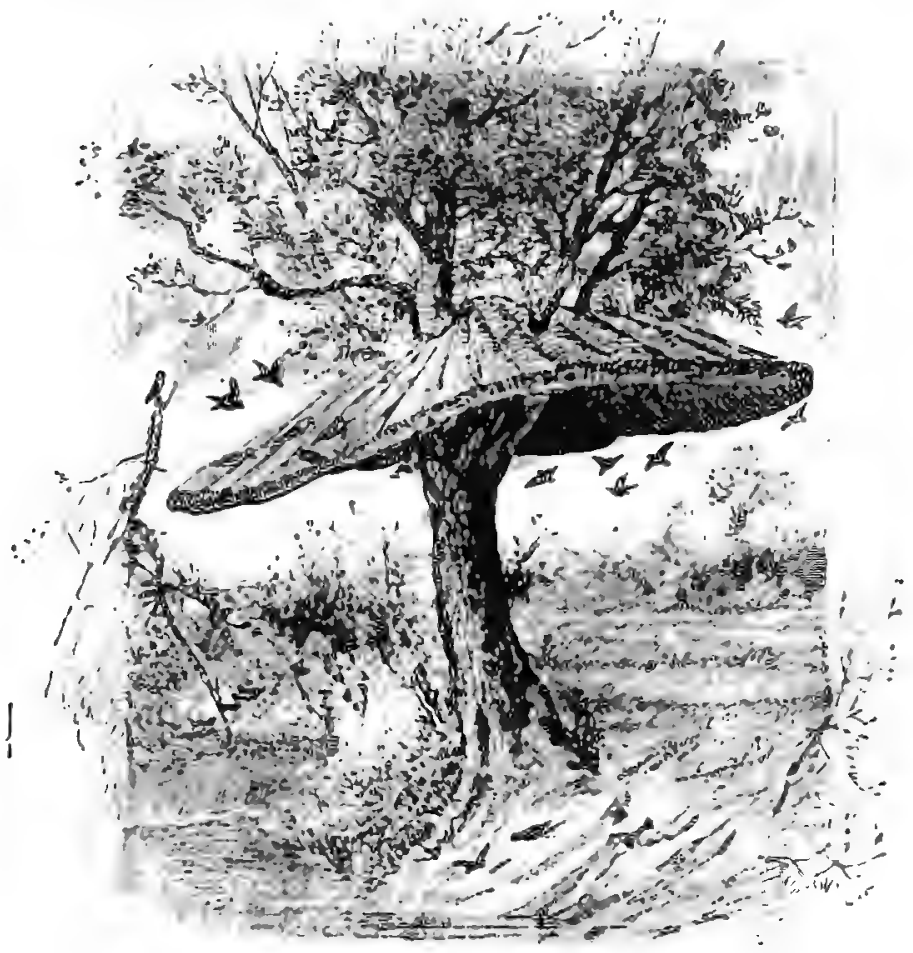

Birds" tenement house.

of those most skillful of all feathered architects, the weaver birds.

some of these birds build double nests, one apart- 
ment of which is occupied by the male, while the mother and her little ones are in an inner chamber. Some of the nests belonging to a different species are not only built out on the extreme end of a flexible branch, but all the twigs that might afford possible foothold to a foe are deliberately stripped off; and still another species, the Mahali weaver birds, cover their nests with a defensive panoply of large, tough, needle-pointed thorns, built into the structure in such a manner that the points project outward.

The buffalo, weaver bird (Textor Dinenulli) builds from three to eight nests combined into one huge structure from five to six feet in length and from four to five in breadth. This may be considered a sort of apartment house, occupied by several families. The noise and bustle about one of these compound nests must be heard to be appreciated.

The real bird tenement house, however, is contrived by the sociable weaver bird (Phileto rus socius). Imagine a structure built by birds th $t$ measure but six inches from the ends of their tails to the tip of their skillful little beaks, which is as large as a native's hut; large enough to shelter five or six men ; large enough, in fact, to break down, as it sometimes does, the tree in which it is built!

Nor must it be supposed that the tree selected is either small and weak, or brittle. There is a species of acacia (Acacia giraffe) known to the Dutch people of South Africa, where it grows, as Kameel-dorn, or camel tree, because they persist in believing the giraffe, which is very fond of its leaves, a sort of 
camel that has run all the substance of its humps into a neck of preposterous length in its efforts to reach and graze upon the foliage; and this tree the social weaver birds almost invariably and very wisely choose for their nests, for, indeed, its fiber is almost as tough and stout as that of the hearts of the Dutch folks themselves, who have with such indomitable resolution and endurance defended their homes against all invaders.

The material of which the nest is constructed is no less strong and wiry. It consists of a grass which almost seems as if created for the purpose; so long, so flexible, so unbreakable and untearable are its blades, that it makes the best and most enduring of mats, and was formerly used by the Bosjemens or Bushmen (hence called Booschamannie grass) to weave into impenetrable defenses against the javelins and arrows of their enemies.

A single pair of birds often set to work on a nest of this kind, carrying the grass to a tree and commencing in a wonderful manner to weave it compactly into a little rain-proof roof. The next season the progeny of the parent birds come back, select mates, and the old homestead is enlarged to suit their convenience, much as we have seen some little cabin built about with wings and additions to accommodate married sons and daughters who came home to live with the old folks.

The narrow structure now widens, and beneath the compactly woven shelter the nests close their ranks and hang shoulder to shoulder, like the cells in 
the comb of a wasp's nest, and accumulate all the more rapidly that the birds refuse to use a last year's nest, leaving it to various rather disreputable tenants, in the way of bats, insects, and reptiles, while they move into cleaner apartments.

In fact, the place is in every respect a tenement house, noisy, and thronged with a miscellaneous multitude of all sorts and conditions of folks, each family keeping house on its own account, and often quarreling not only with other households but among its own members. The roof, however, unlike that of its human prototype, effectually keeps out not only rain, but thieves and murderers; bird-and egg-eating snakes and monkeys can not effect an entrance, and the occupants of the nest are safe.

\section{THE BAYA BIRD.}

A CLEVER LITTLE ARCHITECT.

What human habitations can rival the dainty architecture of the birds? In adaptation of materials, form, and size to the use designed, what equals the snug and airy domicile swung on the extremest tip of a pliant twig, the pendant home of the oriole; or the nest of the wren, deftly concealed in the perfumed shadows of clover blossoms or violets; or the exquisite nest of the hummingbird, built of lichens and mimicking the knot of an old trec; or, indeed, a thousand others? 


\section{CURULS HWMES ANI THEIR THXANTS}

All combine eoonomy of rimon with heanes, strength, and sáfety, as no man-ibelling ecer diil:

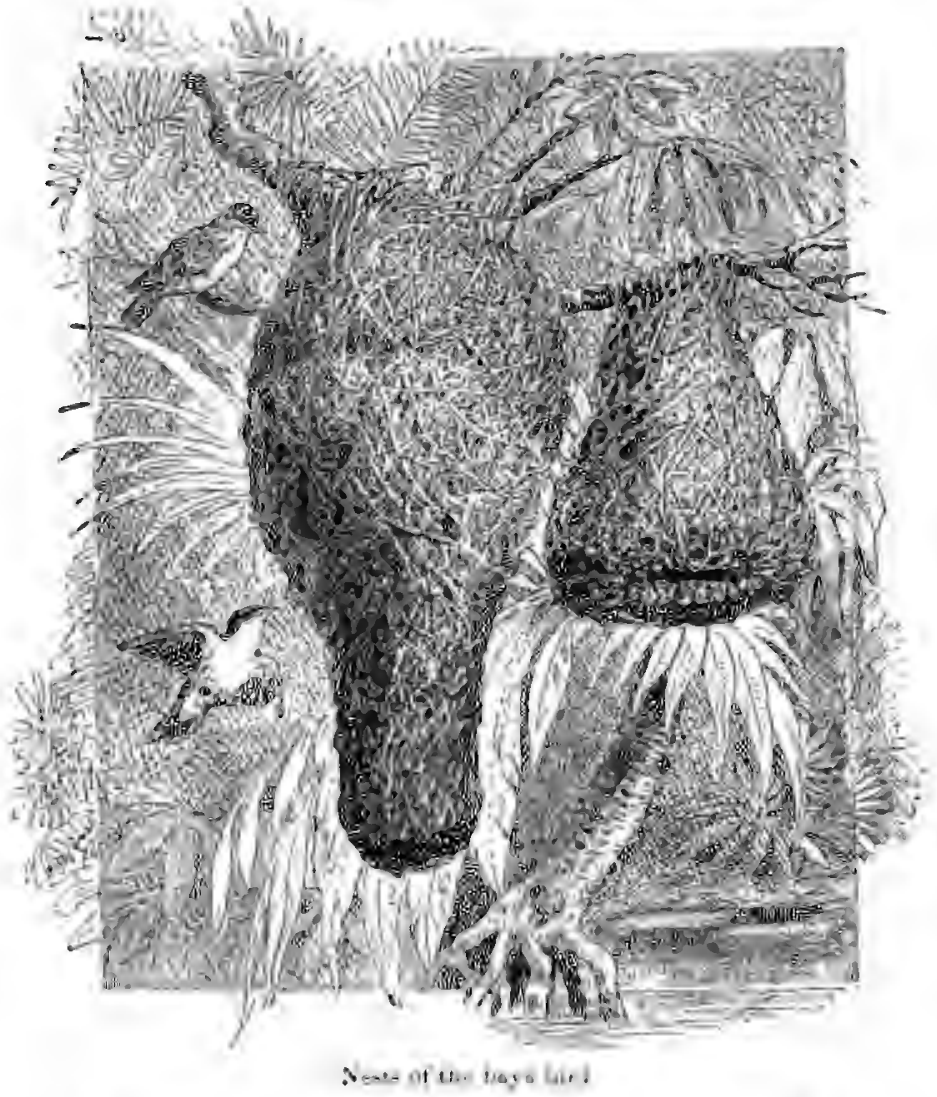

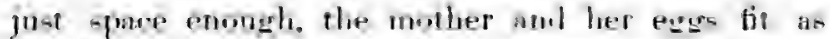

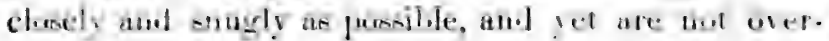


cromded; just room enough, too, for the nestlings until they brim over its mossy sides and fly away to build homes for themselves; just the combination of hammock, house, and cradle that best suits the winged home-makers who never stay indoors except to brood their little ones to life with their soft, war'm bodies, and to feed them until they have attained strength and bird wisdom sufficient for self-support.

So temporary and merely incidental to the whirl of sportive delight which constitutes their life do many tribes of feathered gypsies consider the nest, that its construction is as slight and unelaborated as the shelter of hemlock boughs built by lone hunters for a night's encampment; but, slight as it may be, it is never inartistic or unsuitable. Indeed, it can not be said without reservation that one nest is better or more skillfully built than another, since all are perfectly adapted to the purposes, habits, and requirements of their builders; but the degrees of labor spent in their construction are as varied as the situations in which birds place their nests or the material with which they build them.

It so happens that one of the wisest and most teachable of little birds is also the builder of one of the most beautiful and elaborate of nests. This is the baya (Neticurvius baya) of India. The nest it makes might be easily mistaken for some grass-made, closely woven, flask-shaped basket of native human manufacture. Dr. Jordane, in his Birds of India, says, in regard to the nest:

"It is apparently made of grass of different kinds, 


\section{CURIOUS IIOMES AND THEIR TENANTS.}

plucked when green, sometimes of strips of plantain leaf, and not infrequently of strips of date-palm or cocoanut, and I have observed that nests made of this last material are smaller and less bulky than those made with grass, as if the little architects were quite aware that with such strong tiber less amount of material was necessary."

The nest is not only handsome and shapely, but it is so well built and so substantial in its structure as to be weather-proof against the downpour of a Malabar or Burmese monsoon. It is very often hung from the branches of palm trees, though otber trees are sometimes used, and in Burmah the eaves of thatched houses seem to be preferred, where twenty or thirty of these long nests, like rows of gourds hung out to ripen and dry, may sometimes be seen; indeed, on one occasion more than a hundred were counted attached all around a single dwelling, and their ingenious builders did not seem in the least disturbed by their close proximity to human neighbors, although in many parts of India the bird is extremely timid and secluded in its habits.

The truth of the matter seems to be that the naturally wild, shrinking, and retiring nature the baya exhilbits in sparsely peopled parts is overcome by the gentle kindness of the native Indians, whom it, in cornmon with all animate Nature, learns to regard as harmless and friendly.

In Oriental countries generally birds and beasts rather tend to become tamer and more fearless than wilder in proportion as human beings become more 
numerous in the localities they frequent. At least this is the case in India and Japan, in which latter country birds actually build their nests in the houses, and are considered part of the families among whom they live.

The nest of the baya consists of three compartments : one, in the long, tubular entrance, is used for what might be called the sitting and sleeping room, which, when the little birds have grown sufficiently and are strong enough, they occupy with their parents, having before been kept in the inner compartment or nursery; another, the third, is placed by the side of the nursery; its use has not been certainly determined by naturalists, though it is thought by some to be the especial property of the male-a sort of growlery, I suppose, to which he can retire after a curtain lecture, or to escape the noise of the young ones, or think over some business matter.

The strangest part of the furnishing and completion of their nests remains to be told. When otherwise finished the nest is studded with balls of soft clay, which the natives declare are used as candlesticks, for in each one of them the baya fastens one of the brilliant tropical fireflies that abound in that region.

Some ornithologists, without any better reason that I can discover than the strangeness of the storyfor scientific folks do not like to credit strange stories which they do not themselves originate-discredit this story of the natives, though they admit the presence of the balls of clay, andcan give none but the most 
far-fetched and absurd conjectures to account for their presence there.

But it is not as nest-builders alone or eren principally that the bayas manifest pre-eminence among birds; for as trick birds they are probably unequaled, rivaling and even surpassing $\operatorname{dog} s$ and monkeys in this respect.

When taken from the nest and brought up by the hand, they can be taught to go down into pits and dry wells and recover any small article dropped therein, carry notes to any designated place on a given signal, or snatch away a hairpin or any small article of jewelry from any person pointed out, besides a great many other tricks much more surprising than these. It may be said, indeed, that only close, loving attention, a faculty of sympathetic interpretation, and expenditure of a little leisure time are required to discover and develop an acquaintance with the ways and wisdom of our commonest birds that will repay a thousandfold the trouble taken with them.

\section{THE CROSSBILL.}

\section{A NEST BUILT IN MIDWINTER.}

Some caged birds, though they do not beat themselves against the bars of their cage and die of fright and despair, are never quite reconciled to captivity, never forget their former liberty, and never cease to long to set their wings to free, untrammeled flight, 
never lose entirely their instinctive fear of human beings-in short, are never very happy. They are uneasy and restless, will not eat when watched, and often grovel in a sort of stupor of abject fear upon the floor of their cage. Their songs-for these poor creatures sing, as captives will, to cheat an aching heart-do not delight the ear that comprehends their import; they rather inspire us to tear open the door of the prison-house and bid the prisoner "Godspeed," than wish to retain him to listen to his sorrowful lamentations.

Such is not the brave little crossbill-brightest, cheerfulest, and best contented of bond-servants; for he is the honored servant not of fear but of love. He has a thousand and one ways of showing this, not the least of which is his evident delight on being noticed or caressed, and the queer little self-taught tricks with which he seeks to entertain his friends. A party of spectators gathered about his cage is a signal for the performance to begin. $\mathrm{He}$ leaps into the ring attached to the roof of his cage, and, falling backward, swings upside down, supported by his claws; taking hold with his bill, which he uses much as a parrot does its beak, and letting go one claw, he hangs suspended; then, loosing his beak, he sways backward and forward, held by one claw alone. The enthusiasm with which all this is done, and the pride and pleasure the crossbill takes in "showing off" before an appreciative assembly, make his performance doubly amusing. After a series of such aërial gymnastics, if a lead pencil, penholder, or any such article 
be extended toward him, he will fasten upon it with his strong beak and allow himself to be carried dangling from the end, uttering a subdued little croak of exultation as he is shown in turn to each one about him. A distinguished ornithologist, writing of this bird, says :

"The dear little bird is so quaint and engaging, and so fearless of human beings, whom it appears never to have learned to regard as enemies, that it seems as if its trustful, innocent ways should be its protection, and that no sportsman could have the heart to shoot it. It is only after repeated experiences of the cruelty and treachery of mankind that it becomes timid and wild. Should his little mate be killed, the crossbill remains sorrowfully perched on the branch from which she has fallen, and revisits the spot again and again in hopes of finding her. $\mathrm{He}$ seems to have so gentle and loving a nature that it is almost impossible for him to understand evil or unkindness. The rapture of affection for his little companion is such that he will flutter over the top of the tree where she sits, never weary of pouring out his whole heart in song, until he sinks to rest on his perch by her side. Besides their song the birds have three funny little words they say to each other. These words are plainly enough 'Gop, gop,' 'gip, gip,' and ' ''ock, yock.' The last is uttered in confidence to each other as they sit side by side, never after they have taken flight. The word 'gip,' repeated once or twice, is as much as to say, 'Look out!' 
"When one of the birds utters it, all are on the alert, and if he flies the whole flock takes wing. 'Gop ' is 'Come back.' When one bird is away from the others and they cry 'Gop!' he immediately returns to the flock."

Both male and female are pretty singers. Their song is copious and melodious, but very tender and soft, especially that of the female. As the birds are hardy and easily kept, it is a little surprising that they are not more often eaged and made pets of. Certainly they are far more interesting than canaries, and more satisfactory in every way than the wild and suspicious creatures whom we keep cruelly and closely confined, . because if we afford them the slightest opportunity they will fly away never to return. There are numerous species of crossbeaks, many of which are found native to the United States, but all have their plumage more or less marked with the crimson stains alluded to by Longfellow in his beautiful little translated poem on this bird, called.

\section{THE LEGEND OF THE CROSSBILL.}

From the German of Julius Mosen.

On the cross the dying Saviour

Heavenward lifts his eyelids calm;

Feels, but scarcely feels, a trembling

In his pierced and bleeding palm.

And by all the world forsaken,

Sees he how with zealous care,

At the ruthless nail of iron,

A little bird is striving there. 
Stained with blood and never tiring,

With its beak it will not cease;

From the cross 'twould free the Saviour,

Its Creator's Son release.

And the Saviour speaks in mildness,

" Blest be thou of all the good!

Bear, in token of this moment,

Marks of blood and holy rood!"

The nest of the crossbill, strange to say, is built, and the young reared, in midwinter, amid snow and ice in the far north-in Labrador, and even in Greenland. The nest, though a pretty little affair, seems illy calculated to keep the eggs or the baby birds from freezing; but the parent birds are very brave and faithful, refusing to leave their eggs, but returning again and again after they have been taken off by the hand.

The eggs, four in number, are among the most beautiful of birds' eggs, being artistically rariegated, marbled, and dotted with various shades of lilac and purplish brown on a greenish-white ground. The birds frequent pine and fir trees, and the apparently awkward shape of their beaks, which cross each other at a considerable angle, is admirably adapted to the habits of the bird. Living mostly on the seeds of the cones of the fir, they hold the cone in their claws, bring the points of the beak directly over each other, and work them between the scales, when, forcing them a little sideways, the scales open, and then, again bringing the points together, they pick out the seed without the least difficulty. 


\section{THE FLOWER-EATER AND ITS PRETTY NEST.}

\section{A BIRD THAT IS SELDOM SEEN.}

Mr. Gould, in his Handbook to the Birds of Australia, writes of the Australian flower-eater as follows:

"By far the greater number of Australians are, I believe, unacquainted with this beautiful little bird, yet there is scarcely an estate in either of the colonies in which it may not be found, either as a permanent resident or an occasional visitor. Its natural disposition, leading it to confine itself almost exclusively to the topmost branches of the loftiest trees, is doubtless the cause of its not being more generally known than it is, not even its rich scarlet breast attracting notice at the distance from the

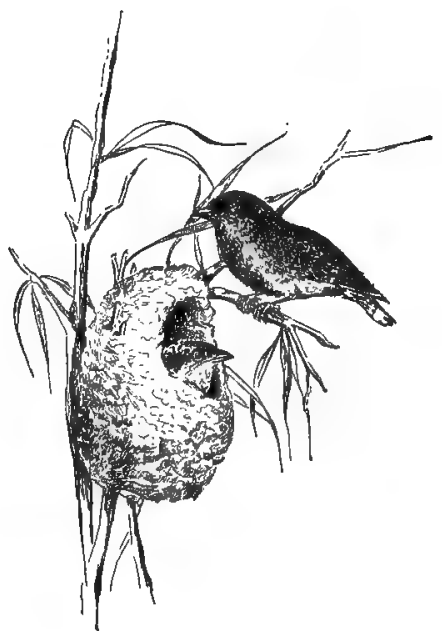

Australian flower-eater and nest. ground at which it generally keeps; and in obtaining specimens I was more generally made aware of its presence by its pretty warbling song than by its move- 
ments among the branches. So small an object, indeed, is most difficult of detection amid the thick foliage of the lofty Casuarince, to which trees it is extremely partial, particularly to those growing on the banks of creeks and rivers.

"It is frequently to be seen among the clusters of the beautiful parasitic Conchllius, which very commonly grows on the Casuarina in the neighborhood of upper Hunter. Whether the bird is attracted to this mistletoe-like plant for the purpose of feeding upon its sweet and juicy berries I could not ascertain; its chief food is insects, but in all probability it varies its food. Its song is a very animated and long-continued strain, but is uttered so inwardly that it is almost necessary to stand beneath the tree upon which the bird is perched before its notes can be heard."

The beautiful nest of this little bird looks at a short distance like a snowball. It is of the purest white, and is formed entirely of the fluffy, cottony substance found in the seed vessels of numerous Australian plants. The color of its pretty little eggs, that look like agate marbles, is a dull white covered with brown specks. 
THE FEATHERED SEAMSTRESS.

THE FEATHERED SEAMSTRESS.

WHAT SHE SEWS.

The first time any sewing was done in this world a little bird was the seamstress, her bill the needle, and the fiber of some plant the thread. She did

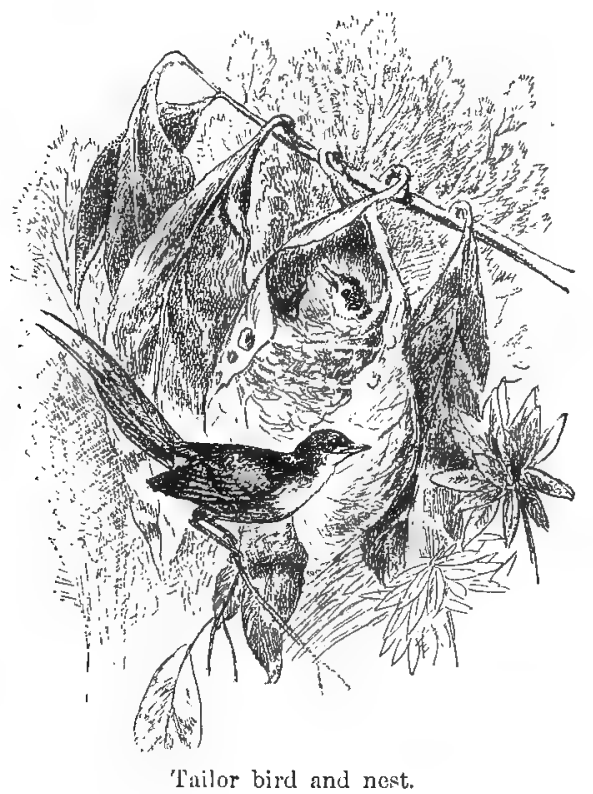

not need to make clothes for herself and her little ones, for Nature provides for all her kind a warm 
and handsome suit of feathers. No, she made a home for her nestlings.

To begin with, she sought out a large leaf that hung at the end of a slender twig and pierced a row of holes along its edge, nsing for this purpose her sharp little beak, as a shoemaker uses his awl. This done, she flew away and plucked another leaf, which she prepared as she had the first. She then peeled the outside of a growing plant into long, slender strips, and, using these for threads, sewed the leaves neatly together in such a way that a long bag, open at the upper end, was made. In this bag, which was in fact a nest, she placed a bed of soft, white down, upon which, when they hatched, the baby lirds rested.

The same kind of bird now liring in India is called a tailor bird. It likes to live near people's houses and in their fields and gardens, and is by no means as timid and shy as other birds.

\section{A FEATHERED PARSON}

AND HIS HOME.

Some time since a friend of mine, having occasion to purchase a small article, entered a little thread-andneedle shop in the environs of the city of New Orleans, but found no one in the place. As she turned about to leave, a hoarse voice called out: "Wait a moment, ma'am. Take a chair." Looking around her in 
some surprise at not seeing any source from which she could suspect the voice to proceed, or any possibility of accepting the invitation so cordially extended her, she replied, "I will wait, but I see no chair."

"Betty! Betty! come quick! come quick! come quick! Some one here.-Take a chair," called out the roice loudly.

Rather alarmed-for there was no one in the little shop but herself-my friend hastened to the door, when she happened to catch sight of a bird-cage just inside it, containing a strange-looking black bird, with two white bands, that reminded her of those worn by English clergymen, extending downward from its throat. At the same moment a woman appeared at the half-opened door leading to the rear of the shop.

"Tas tha burd b" talken, mum," said she, with a strong north-of-England accent. "Tas a parson, mum; them do go on worse'n parrots."

On inquiry, the talker proved to be what naturalists call a Prosthemadera, which had been brought by the shopkeeper all the way from New Zealand, where she had formerly resided, of which island the bird is a native.

Its popular name, "parson bird," given it by the early colonists of New Zealand in allusion to the peculiar tufts of long white feathers that hang down from the throat as if to set off its glossy black plumage, and which resemble clerical bands, certainly seems appropriate.

Perched on a stump, as an extemporized pulpit, it 
gives vent to a jargon of sounds, displaying its bands and gesticulating in a manner that irresistibly reminds one of the declamatory style of preaching. A gentleman describing the bird says: " $\mathrm{He}$ shakes his head, bending to one side, then to the other, as if he made remarks first to this part of his hearers and afterward to that; and once and again, with pent-up vehemence, contracting his muscles and drawing himself together, his voice waxes loud, as if to awaken sleepers to their senses."

It is a favorite cage bird with the colonists, being easily reared in confinement, and its extraordinary powers of mimicry make it a very interesting pet. It can repeat whole sentences, and imitate, among other things, the barking of a dog to perfection. Its memory, teachableness, and articulation are better than those of any parrot; in fact, perhaps it is the best talker among birds.

Not only is the parson bird an excellent talker, but it is also one of the sweetest singers in the world.

Sir Walter Buller, who has seen the bird in a state of nature, writes: "It is incessantly on the move, pansing only to utter its joyous notes. The early morning is the period devoted to melody, and the birds then perform in concert, gladdening the woods with their wild ecstasy.

"When engaged in song, the parson bird puffs out the feathers of his body, distends his throat, opens wide his beak, with the tongue raised and slightly protruded, and gesticulates with his head as he pours forth the wild harmony of his soul. 
"A pair may often be observed scarce a foot apart on the same branch performing a concert, for both sexes sing. The notes are rich and varied, now resembling the striking together of metallic rods, then a long-drawn sigh, a warble and a sob, followed by a note of great sweetness like a touch on the high stops of an organ. One of its finest notes is a clear, silvery toll, followed by a toll, and then another toll; the performance lasting sometimes an hour or more.

"This is generally heard at the close of the day, or just before the bird betakes itself to roost for the night. . . . At other times it may be heard uttering a sweet, warbling note, followed by a sneeze, after that a pause, and then a sharp cry of tu-whit, tu-whit, oo-a pause again, and then its warbling note with variations, very soft and liquid, but ending abruptly in a sound like the breaking of glass."

The parson bird builds a large, well-constructed nest. Selecting the fork of some bushy shrub, it lays a foundation, a few feet from the ground, of stont twigs or dry sticks; upon this it builds its walls of coarse moss and lichens, and last of all lines the structure with fine, soft grass. The eggs are white, powdered with reddish-brown spots and specks. The babies when first hatched are almost entirely naked, but a warm coat of feathers is soon supplied by kind Mother Nature, and the little ones grow rapidly.

The parson bird rears two broods a year, which is fortunate, considering the fact that the bird, which has, comparatively speaking, been little known to 
civilized man, is apt to prove so valuable a cage bird, uniting and excelling, as it does, the abilities and accomplishments of the parrot and the mockingbird.

\section{STEALING A HOME.}

FROM PERSONAL OBSERVATION.

When the broad lily pads begin to cover the surface of the ponds with green, and the growing leaves of trees and shrubs yet retain their tender tints of pink, the summer yellowbird makes his appearace, and from hedge and bush may be heard his song, as simple and pleasing as the tasteful but modest plumage that covers his little person. As soon as they arrive among us these busy little birds begin to prepare for housekeeping. The male bird flies about looking for such things as feathers, plants, dried ferns, catkins from willows, or anything else that will answer his purpose, all of which he brings to his mate, who builds them into a pretty nest. So quickly and deftly do this little couple labor that they make the greater part of their home in a single day.

There is often another party watching the building of the nest with concern-a houseless, happy-golucky gypsy, who has a tramp's interest in the housekeeping of most of the smaller feathered dwellers of the wood; this is the well-known cow blackbird, who does not like to give up her freedom for family cares. 
Having put out her babies to be brought up by strangers, she seems to prefer the company of cattle to that of her family. The cow blackbird lays its ! eggs in the nests of all kinds of smalier birds, and her eggs hatch a day or two before those that rightly belong in the nest. So, when the little birds are afterward born in the nest, they find themselves crowded by the larger and stronger strangers, who, on account of their size and strength, come in for a lion's share of all the food provided by the parent birds. Thus the nest-builders rear the strangers, while their own young ones starve. It is really a pitiful sight to see a couple of little greenlets anxiously searching from daybreak till evening for food to fill the crop of one or more young cow blackbirds much larger than the greenlets themselves. The summer yellowbirds, though confiding little creatures, are not so readily imposed upon: they seem to know their small, greenish, prettily marked eggr from the great, dark ones the lazy cow blackbirds have smuggled into their cozy nest. The little couple cling to the spot chosen for their home and will not leave it, neither will they consent to hatch the strange eggs. What then is to be done? The intruders are too large and heary to be thrown out. The little birds do not hesitate long. Unmindful of the new labor imposed upon them, they set to work and build a new nest upon the old one-a second story to their house-in which they now lay their own eggs. Sometimes three or four nests have been found all built one upon another by these birds, to escape hatching the strange eggs imposed upon them. 
140 CURIOUS IIONES AND THEIR TENANTS.

\section{WALLED UP.}

STR.NNGE HABITS OF A RARE BIRD.

There are now on exhibition at the Zoölogical Gardens in London several very rare birds, among the most curious of which is the hornbill, a genus about which little is known. The systematic study

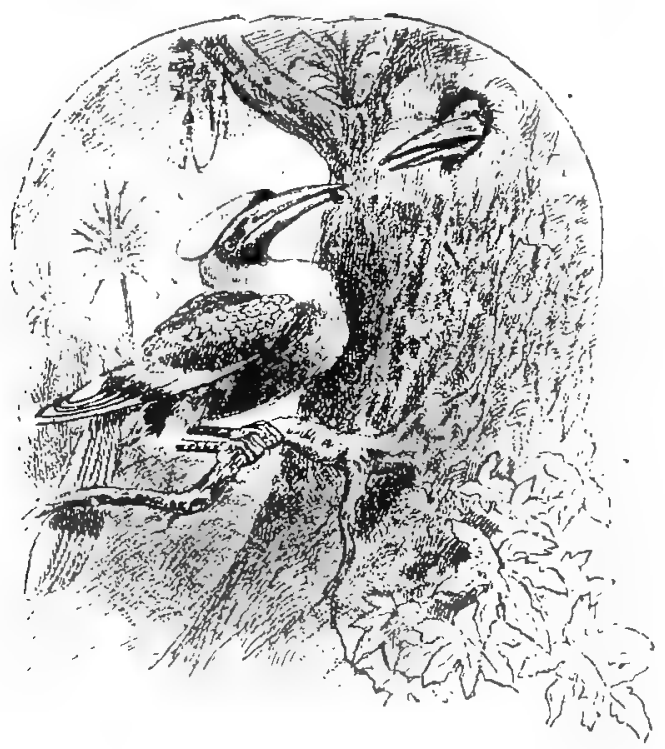

Hornbill feeding mate.

of these specimens by naturalists has developed traits new to those who have had the rare opportunity of 
observing the bird in its wild state. The hormbills are kept in a special aviary, apart from all others, and are the first birds of the sort ever brought to Europe. The strangest purpose, perhaps, to which the beak of a bird is ever applied occurs in the use of it by these very hornbills. These beaks are of such ample proportions that, until we learn that they are the merest shells of thin, horny substance, filled with light cellular tissue, we may well wonder how the birds ever manage to carry them, especially as, in addition to the bulkiness of the real beaks, the upper mandible bears above it a sort of annex, or supernumerary structure, as large as the beak itself.

Such a utensil-although it is used very dexterously-is out of the question in nest-building, and consequently the hornbill leaves that business to birds with beaks of more manageable proportions. A hollow tree is good enough for lim, and when he and his wife go house-hunting, in the spring of the year, they are on the lookout for an apartment of suitable proportions, with a doorway which, if too small, they can enlarge for themselves. The situation must be secluded but lofty, and within conrenient distance of fruit-bearing trees.

When a suitable abode is selected, Mrs. Hornbill retires into the deepest recesses and gives herself up to family cares, plucking from her own body the feathers which make a soft bed for eggs and nestlings. Henceforth she is at home to no one until her children have grown large enough and strong enough to leave thcir home, because, unable to fly or defend 
herself or her little ones, she is the most helpless of creatures. Mr. Hornbill, however, proves equal to the emergency, and his beak is none too large to serve his purpose, for with it he transports great loads of clay and plasters up the entrance to his wife's apartment, making it serve him first as a hod and then as a trowel. In thus walling his wife up in the tree he secures her safety and concealment, but in order to feed her he has to make a little window or hole in the wall large enough for her to protrucle the tip of her beak to receive the food with which he constantly supplies her.

$\mathrm{He}$ is very faithful in attending to her wants. Indeed, the poor fellow works so hard that he wastes away and becomes so weak that on a sudden lowering of the temperature during a cold rain he sometimes sinks to the earth and dies.

The mother and the nestlings, on the contrary, grow fat and heavy, and are looked upon as a prize by the natives when they can find them. The babies (there are generally two) are the queerest-looking pink-and-white bags of jelly it is possible to imagine. They are about the size of full-grown pigeons before they acquire their plumage, and it is three months after they are hatched before they are ready to leave their nest.

When Mr. Hornbill comes to the tree he alights on a branch or clings to the bark near the hole where his family is, and knocks with his beak. Immediately his wife's beak appears at the little window and receives the small bag of fruit which he always pre- 
sents her. The bag is the inside coating of his stomach, and he grows one after the other in constant and very rapid succession as long as his wife requires to be fed.

If Mrs. Hornbill breaks down the partition her mate has built up at the entrance of her apartment, or if he catches another hornbill feeding her, the natives say he flies away and never returns.

Hornbills, like the Chinese, are fond of their own music-which is a comfort to think of, for otherwise it is very certain no one would appreciate it. It is something between the shriek of a locomotive and the braying of a donkey, with a catch in it now and then like the laugh of a hyena. The wings of a number flying together make a noise that we are assured may be heard a mile off; and when a flock of birds musically inclined are on the wing, their flight sounds like a train of cars rattling past.

If you ever happen to visit the Zoölogical Garden in London, where specimens of these birds are kept, it will be well worth your while to give the keeper a half crown to see them fed. Our best ball players could take points from them in respect to the way they eatch the fruit thrown to them. No matter how fast it comes, or from what direction, they never miss-seldom, even, when two or more grapes or dates are thrown at once. The ease and dexterity with which they use their great bills are wonderful. In picking food from the ground, they first give it a sort of toss and catch it before swallowing it. 
144 CURIOUS HOMES AND TIEIR TENANTS.

\section{A WOOD-EATER}

AND HER NEST.

Among the many substances devoured by animals are some that seem entirely unfit to eat-mud and poisonous plants and toadstools. The scoletus lives upon bark and timber, and craves no other food. She belongs to a tribe that is made up of a great many species, and each species selects the particular kind of wood it wishes to live upon, and will not readily eat any other. Some prefer elm, some oak, others ash; there are, in fact, few sorts of timber that do not appeal to the taste of sorne one of the scoletus tribe.

The scoletus is a beetle, and she is called scoletus because she looks as if she was sawed or cut off short and square at both ends. The name is from the Greek, and means "cut off short.

Madame Cut-off-Short haring chosen the tree best suited for her purpose-she prefers a sickly or dying one-proceeds to eat her way into the bark, boring a round hole that looks as if made by a shot. When she reaches solid timber she burrows a long passage, sometimes deeply into the tree, at other times between the bark and the wood. The end of this passage marks the end of her life, for, turning, she retraces her steps, laying eggs as slee goes at regular distances apart along the gallery, and haring reached the en- 
trance there, in most cases dies, leaving her body to stop up the passage and protect her nursery from possible intruders.

In course of time the eggs produce tiny white grubs that, as soon as they are boru, begin to feed

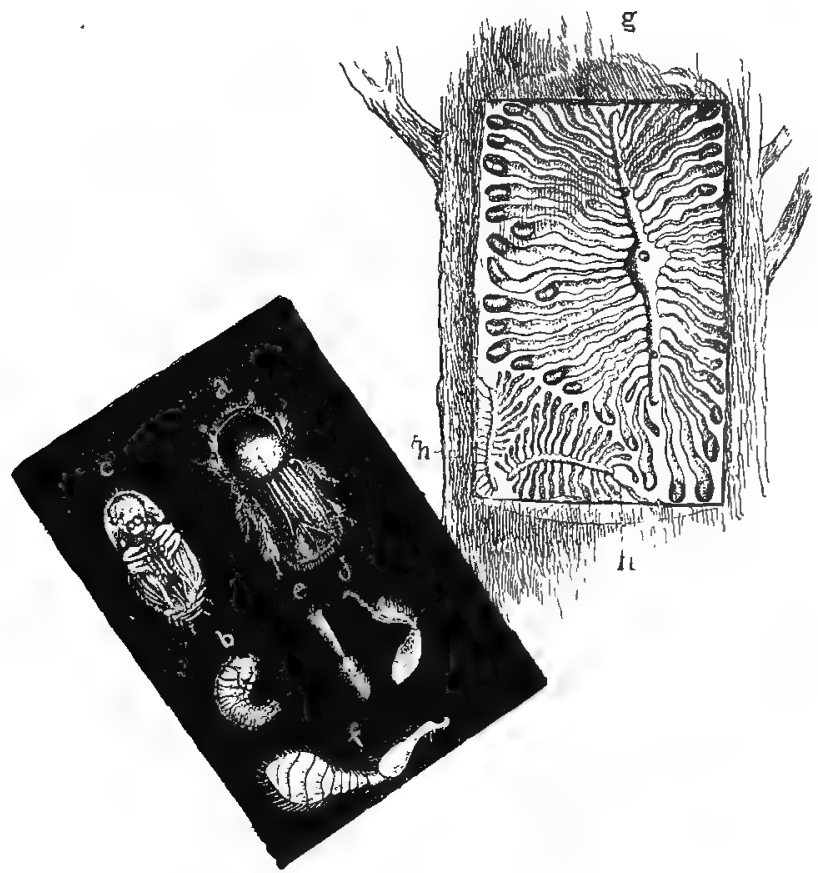

$a$, Scoletus full grown; $c$, under side of same; $b$, grub; $e$, foot; $d$, foreleg; $f$, antenna; $g$, burrows; $h$, burrows of a smaller species.

upon the substance of the tree. Instructed by an instinct implanted in them by an all-wise Creator, they start off at such an angle from the main gallery as 
shall make it impossible to meet or interfere with the burrows made by their brothers and sisters, those at the extreme ends running very obliquely, while those in the center are almost at right angles to the passage from which they started. Indeed, looking at the illustration, it becomes very plain that, as the grubs go on growing larger and their galleries widening to accommodate their increasing proportions, if they all started on parallel lines their galleries would soon run together and the grubs could not come at their proper amount of food. When they make their way into daylight they become full-minged beetles.

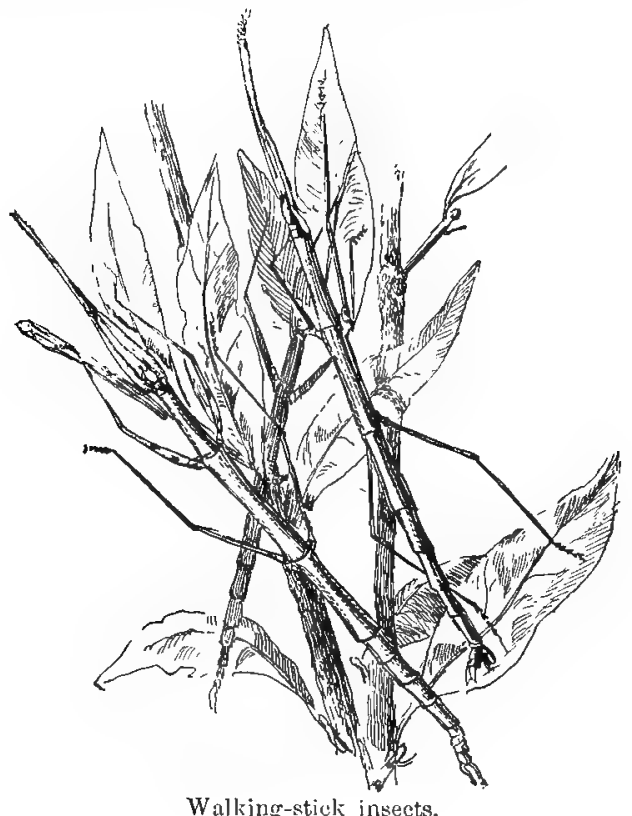

Walking-stick insects. 


\section{BUTTERFLY HOUSE.}

HOW IT WAS BUILT.

A great party of caterpillars together on a tree in Mexico determined to build thernselves

a house. Nature taught them how to do it. They began by spinning a silk web about a twig that descended from a large branch. This done, they constructed their walls, spinning and weaving the silk as they pro-

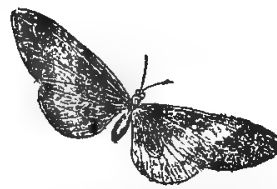

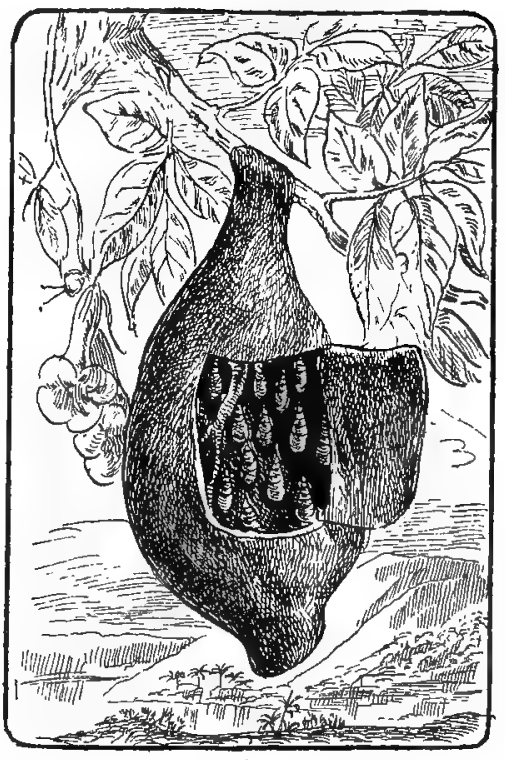

Butterfly house. ceeded, not building upward, as men do, but downward from the roof.

The walls of the house were constructed of silk, so closely woven that they seemed made of parchment, and the whole habitation when finished was shaped like a bottle. The only opening in the house 


\section{$1 \pm 8$ CURIOUS HOMES AND THEIR TENANTS.}

consisted of a circular door at the bottom. Through this door the inmates were to escape when the proper day came for them to do so. Before this, however, and waiting for their time, they hung themselves up on the wall by their tails and entered the pupæ state, which, you know, caterpillars do by changing their skins and becoming pupæ or chrysalids.

The little door was too small to allow the butterflies to escape after their wings had expanded and dried, so that they had to be careful to get out while they were yet moist and flexible. Before this happened, however, a gentleman saw the nest, captured it, ancl carried it away with him to England, where it now is in the museum at Oxford, together with specimens of the sort of butterfly that builds such nests.

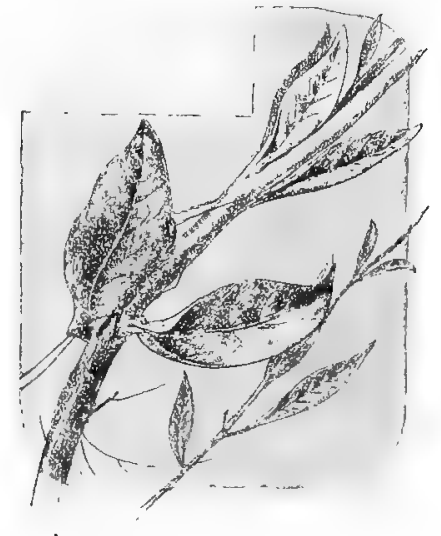

Butterfly that nimies a leaf. 


\section{WASPS' NESTS.}

HOW AND WHY THEY ARE BUILT.

If we will but think of it a moment, we must realize, to some extent at least, how wonderful it is that the many insects that spend the whole of their little lives in laboring for the welfare of the next generation can foresee and provide so perfectly and adequately for the wants of their descendants, each in its own particular manner, to protect their young from severities of the weather or the attacks of enemies, and secure and store up food for their use.

Often building for these purposes, by the united efforts of thousands of individuals, edifices that in architectural excellence and the expert application of mechanical principles far surpass any structures of the lower animals, and sometimes even those of man himself, it adds greatly to our wonder at these marvelous habitations when we remember that the creatures displaying such knowledge and skill in their construction have served no apprenticeship to their trade, or gone to any school or been taught by observation or experience what to do or how to do it. A swarm of bees or of wasps understand the business of their lives as the stomach knows how to digest food or the heart knows how to beat. It is far otherwise with human beings, who know little or nothing but what they learn by study and practice. 
Among insects that appear to show great ingenuity in building their nests are the social wasps. In comparing their colonies and their habitations with those of the antis and the honey-making bees, it must not be foresten that, unlike the commonwealth and structures of the latter, they have only a temporary existence. On the approach of winter the males and workers perish, and of all the busy society, numbering in the height of the season thousands of individuals, only a few fermales survive that, seeking such shelter as they can find in crevices in rocks or walls or the bark of trees, pass the winter in a dormant state.

Awakened from her deatllike sleep by the warm winds of spring, each of these insects forms a new colony. At first she does double duty-she is loth queen and worker. A small nest is hegun, curgs are laid in it, and when the baby wasps-the larvas, as the young of insects are caller--are hatched she feeds and cares for them until they outgrow their larval condition as grubs and become perfect insects like herself. The first brood consists of worker's only. They immediately begin to help their mother in her household affairs, and soon leave her nothing to do but lay eggs and assist in the care of the young.

The paper of which the nests of the social wasps consist, as is elsewhere stated, is marle of woml. The wasps bite off particles of it from weather-beaten elapboards of houses and partly decayed planks and rails in fences, and by chewing it make it into pulp, which "in be easily shaped and molded, and readily dries on exposure to the air. Like thuse of the honey- 
bees, the nests of the social wasps consist principally of combs formed of six-sided cells like those of a honeycomb, from which, however, it differs in more than one important respect. It consists of a single

Nest of South American wasp.

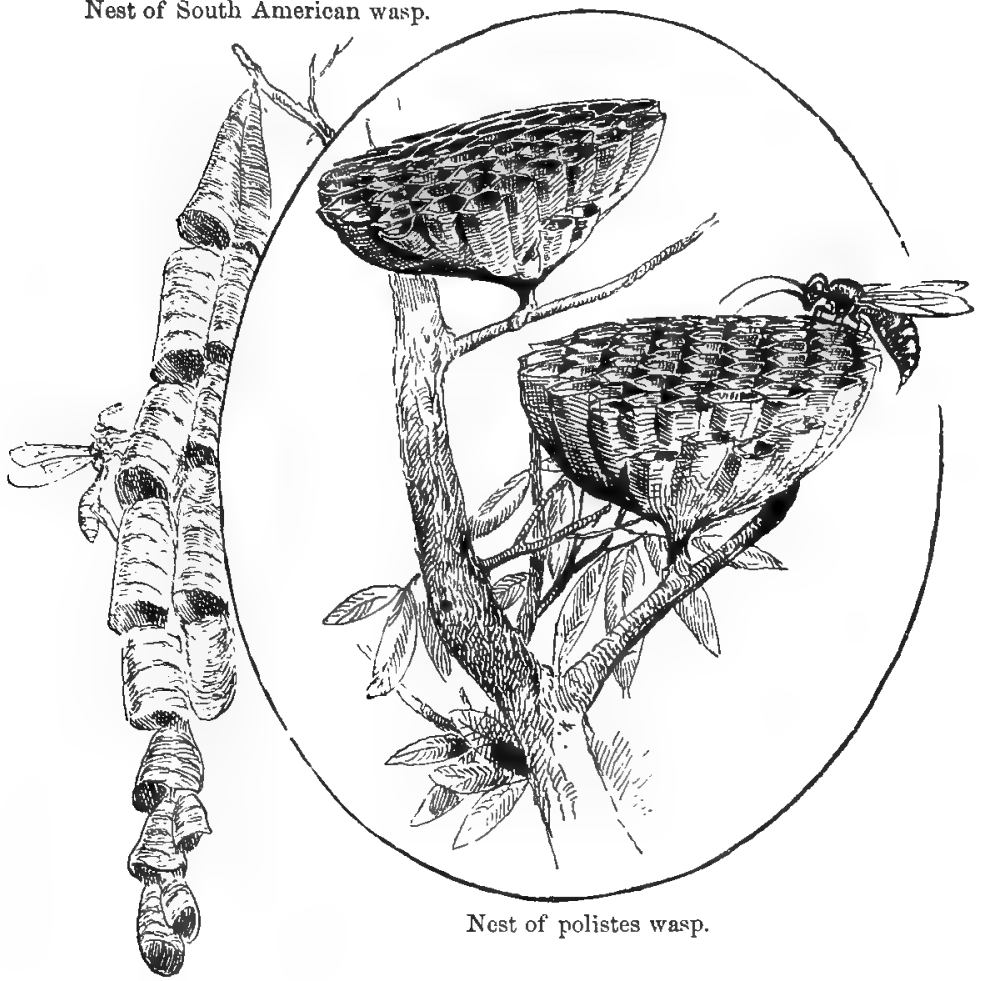

layer of cells instead of two; these cells are usually placed perpendicularly instead of horizontally, as are 
the cells in honeycomb; and, lastly, they are made of paper instead of wax.

In some cases, as that shown in the illustration, the nest consists of a single comb held in place with one or more stout stems, and is open to the air. This is the nest of the polistes wasp; in others there is a series of combs placed one above the other, and the whole is covered by a shell or case consisting of a number of thicknesses of paper.

The nests are suspended from the branches of bushes or trees. Each cell in a comb is occupied by an egg, and when the grub hatches it hangs head downward in its cell, except when the cell opens upward. At first the grub is fastened in its place with a sort of glue supplied by the workers, but it soon grows so fat that it fits in the cell too tightly to fall out. It receives constant attention from the workers and females, and is fed with nectar and the juices of fruits, and insects (for wasps are meat- as well as fruiteaters), and by more solid food chewed fine by its nurses before feeding.

When the young wasp enters the winged state and leaves its place the cell is thoroughly cleaned out and another egr deposited in it. It takes about a month from the time the egg is laid to that in which the perfect insect leaves the cell, so that it can be used several times during a season. The perfect females, or queens, and the males are not developed until late in the season.

Both nests shown in the illustration belong to the polistes wasp, the one in the ellipse a European and the other a South American variety. 
If the ordinary social wasp queen described has to perform double duty, that of the South American polistes is triple. To quote a writer who has described her manner of life :

"The hard-worked mother has to engage in three distinct labors - namely, the building of cells, the enlargement of existing cells, and the nurture of the larvæ"; for no sooner has she formed the third or fourth cell than the eggs in the first and second have been hatched and the larvæ need to be fed. So the mother insect, in addition to her labor as a housebuilder in constructing new cells, has to feed the young in those already made. Soon, however, her work increases; the grubs in the first two or three cells enlarge so fast that it is not long before they outgrow their rather confined quarters. The cells must be widened to accommodate the increase in the size of their tenants, and the tenants' appetites increase with their size. Surely the poor queen must long for the time when her daughters are sufficiently grown to help her.

The manner in which the pretty banded cells are arranged is peculiar, and very decorative from an artist's point of view.

The other nest shows a beautiful group of radiating cells opening upward and very closely balanced on a footstalk. Our American wasps have invented an improvement on this nest, for the cells in theirs open downward, and are of course not so apt to suffer from sun and rain. 


\section{HUMAN NEST-BUILDERS.}

The difference. strictly considered, between a house and a nest may be taken to consist in the fact that a house has walls and roof, and can be made to shut in and lide its inmates from public view, and incidentally that it is meant for a more or less permanent resident (the word from which house is derived means "to hide"); while a nest, open at least in part to wind and weather, is more of a temporary than a permanent resting place; the word nest meaning originally "a place to sit down in."

A nest is renerally used as a receptacle prepared by beast, birl, insect, spider, or reptile for holding eggs to be hatched; but not always, for some birds and beasts, and particularly some of the larger apes, make nests for other purposes.

It is not generally known that tribes of human beings exist who build true nests.

Diogenes, the famous Greek philosopher, who, it is said, lived in a tub, and believed that no one should bother himself with what he could do without, might have learned from the Bushmen of Africa to do without his tub. The favorite dwelling places of these primitive people are caves, which they regard as realy-made habitations that cost no trouble in preparing; but in parts of the land he inhabits, where there are no cares, the Bushman makes himself nests. Finding a suitable bush, he arranges the boughs in the 
best manner he can to form some sort of a shelter, and creeps into it. After the nest has been used for some time young twigs grow up about it and increase its resemblance to a huge bird's nest, which is carried

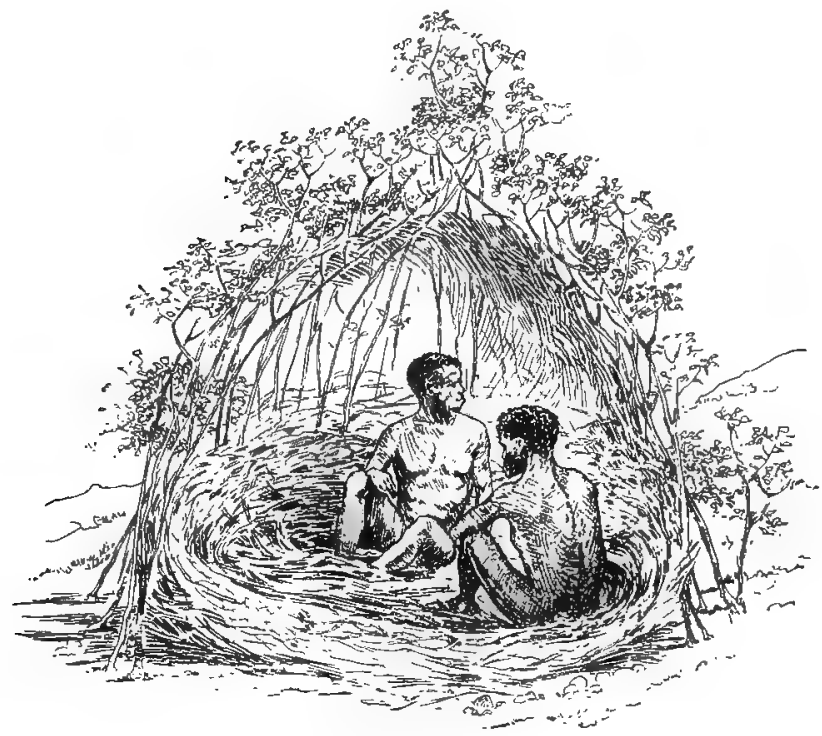

Bushmen in their nest.

still further by the custom its occupants have of lining it with grass, leaves, wool, or other soft materials.

It is, indeed, this nest-making habit that has given this group of South African negroes the name of Bushmen.

The native of Australia, whose development among the races of human beings in the world is about on a par with that of the Bushmen, whom in many par- 
ticulars he curiously resembles, is also a nest-builder. His nests, however-scarcely worthy of the name, though they are his only habitation-are even more rudely built than those of the South African savage. They are made by disposing a number of leafy boughs partly around a space of ground varying in extent with the number of the members of the family occupying it.

These boughs form a rampart or wall from three to four feet high, sheltering to some extent the natives who sit or who lie down and sleep beneath it.

The tribes approaching nearest the utterly savage condition of the Australians and the Bushmen are the natives of Terra del Fuego and of Patagonia, and these, too, build nests, consisting merely of shelters, open in front on the side opposite that of the prevailing winds.

Although so immeasurably below us in respect to civilization, these rude tribes can teach us something. Except so far as they have been led astray and taught bad habits by civilized men or tribes who have learned the vices of civilization, they use no intoxicating drug or liquor. There are at the present day few, if any, who have not learned to do so, but in their original savage state they were ignorant of such things, and were in this respect fortunate in their ignorance. Their wants are few and easily supplied, and they live so closely to Nature that their senses in many respects are far keener and more cultivated than ours. 


\section{A QUEER LITTLE KANGAROO'S NEST.}

Among the mammals that build nests like birds, the brush-tailed bettong is one of the most remarkable.

In the great island continent of Australia, where every production of Nature is so much unlike that found anywhere else in the world that it almost seems to belong to another planet, there exist, as might be supposed, a great many curious animals, among which are a number of varieties of the kangaroo tribe.

These mammals, as you very likely know, are practically bipeds, and not quadrupeds, as are dogs and cats, and, in fact, all beasts to which we are accustomed-that is, they go upon two legs instead of four, not walking or running, but always hopping or leaping, and some of them can make the most tremendous hops, fifteen feet and more at a single jump. They have been known to leap over the head of a man on horseback.

It is remarkable that most Australian animals—not true kangaroos alone, but wolves, squirrels, weasels and badgers, rats and mice, hares and foxes, or at least the Australian mammals most resembling these animals-are all marsupials or pouched animals, having, like our opossum, a pocket or pouch in which to carry their little ones.

Among the kangaroos are some that climb treesalthough, it must be confessed, an animal of the kind 
seems rather awkwardly constructed for a tree-climber - and others that build clever little nests, generally in a hollow in the ground which they find or dig out for the purpose.

Of all the kangaroo tribe the tuft-tailed potoroo is the only one, it seems, that has any prehensile power, or power to lay hold of anything, in the tail. The tip of this useful member has a brush of long hairs, making a sort of tufted knot at the end, which, with the action of the muscles beneath, gives the animal the ability of encircling and holding on to objects with

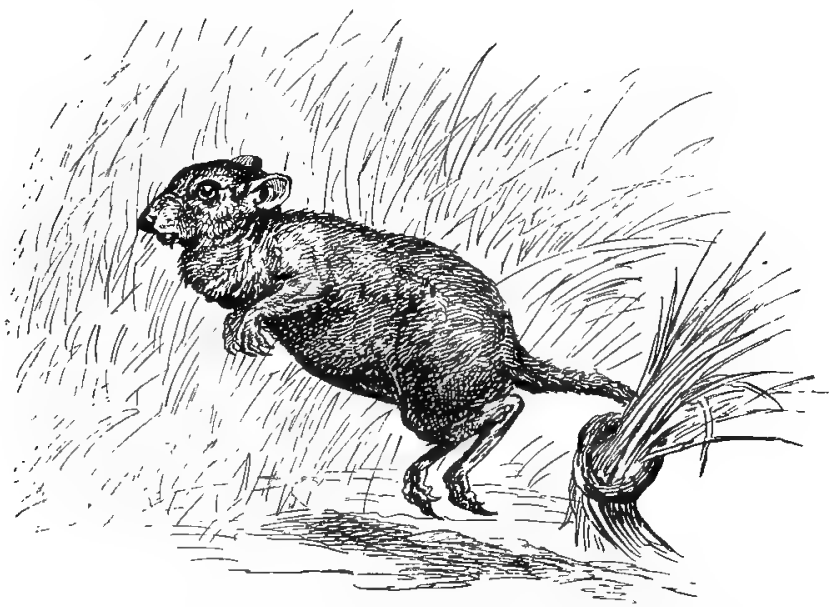

Potoroo earrying grass with which to build its luest.

its tail, and particularly of seizing and carrying the bunches of grass it uses in building its nest.

The country where the tuft-tailed potoroo abounds has no cover or hiding places, consisting, as it mostly 
does, of natural meadows or prairie land without trees or rocks; and the question which the little creature has to solve is how to build a home big enough to live in, and yet small enough to escape being found. It is not an easy problem, for the potoroo is as large as a hare, with a tail almost a foot long, and the nest must at times be used to shelter and conceal his little ones.

The animal solves the enigma very cleverly. First finding or making a hollow in the earth deep enough for his purpose, and, if possible, close to a tall tuft of grass, it constructs over it an ingeniously contrived roof of stalks, leaves, and blades of grass, which, being nearly level with the ground and artfully arranged to look like its surroundings, is as entirely hidden as if it were twenty feet under the surface-that is, hidden from all eyes but those of a native educated to see what is invisible to civilized man. No potoroo, or any other animal, for that matter, in the land where he lives can deceive him or escape being cooked and eaten by him.

As the potoroo can not always find grass suitable for his nest close at hand, he is often obliged to bring it from a distance, and--were the story told by any one less trustworthy than Mr. Gould, the great naturalist, it would not be believed - he does this by gathering the grass he needs into a large sheaf, wrapping his tail around it and setting out for home as fast as he can go, dragging his load behind him. After the little fellow and his family creep in, drag some grass after them and close up the place, they are at home to no one until the evening, when they venture forth and scratch about and dig up roots with their strong fore paws. 
160 CURIOUS HOMES AND THEIR TENANTS.

\section{NEST OF PIG`S FEET.}

THE CHCROPUS (PIG FOOT) AND NEST.

Among the little mammals found in Australia that build nests like those of birds in the grass are some in which the peculiarities of different sorts of animals seem curiously compounded. In the choropus, for

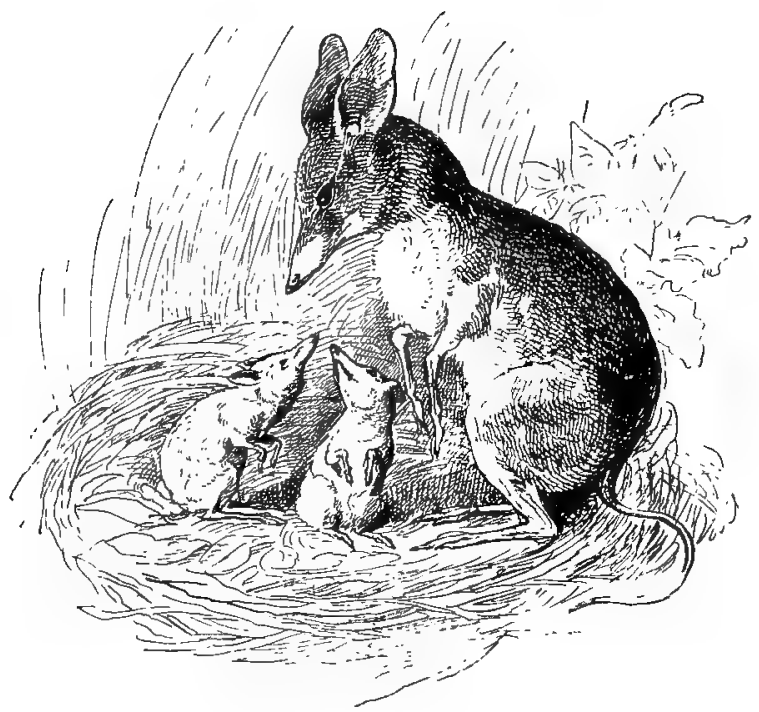

Choropus, nest, and young.

instance, judging from outward appearances at least, exists a union of two very dissimilar creatures-a pig and a rabbit. The long, pointed face, and the feet 
with three tiny, sharp hoofs, are decidedly piglike, while the great ears, soft, furry body, and mode of progression by leaps, are peculiarities belonging no less to the rabbit tribes.

Upon examination, however, it will be seen that while the fore feet possess two hoofs like those of a pig, the hinder ones have, like a horse or donkey, only one; and, as if to add to the seeming incongruities of the animal's make-up, it has a pouch in which, like a kangaroo, it keeps its little ones until they are old enough to seek shelter in the nest of leaves and other substances the mother makes for them. It is an active creature, hopping about on its little limbs, no thicker than goosequills, in pursuit of the insects upon which it lives.

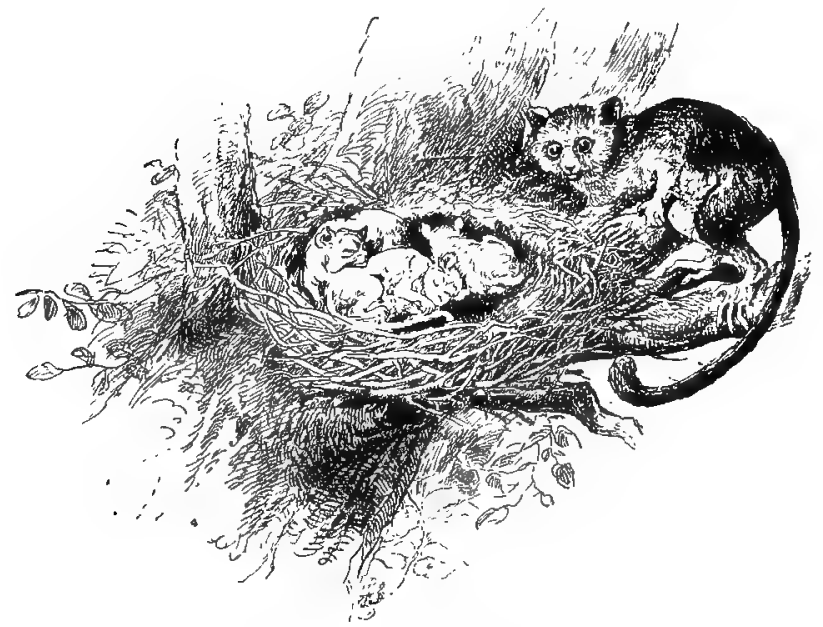

Nest of the cheirogale. 


\title{
THE SMALLEST AND PRETTIEST OF MICE,
}

\author{
HE BUILDS A NEST LIKE A BIRD.
}

His form so slender and graceful, his eyes so bright, without a trace of the fierce cunning that characterizes those of the rat; his sleek, neatly fitting coat of such a rich, red-brown color that shows a variation of tint in different lights, worn with a spotless white vest, and above all his clean and dainty habits, free him from the repulsiveness that seems to belong to other mombers of his family.

If Master Tom Thumb, as the old English fairy tale has it, found a mouse in proportion to his own inches, the proper size for his horse, he might with equal justice, as far as size is concerned, have sought a substitute for a dog among the harvest mice, for these tiny animals when full grown are only one sixth the weight and bulk of an ordinary mouse. A grownup harvest mouse measures, head and body together, about two and a half inches, not counting his tail, which is nearly as long as himself. And as for the babies, they are so small that they might be taken for young hummingbirds, which indeed they rather resemble.

Small as he is-much smaller than some insects and spiders-he shows more intelligence than many a mammal hundreds of times his size (a hippopotamus, for instance); and his hal,its, clean and dainty-for he 
has never taken to living in kitchen drains and in slums, as have his larger cousins, but is country bred - make him a very lovable and interesting pet.

$\mathrm{He}$ is wonderfully lively and active, and is seldom quiet except when asleep, or sitting up like a little

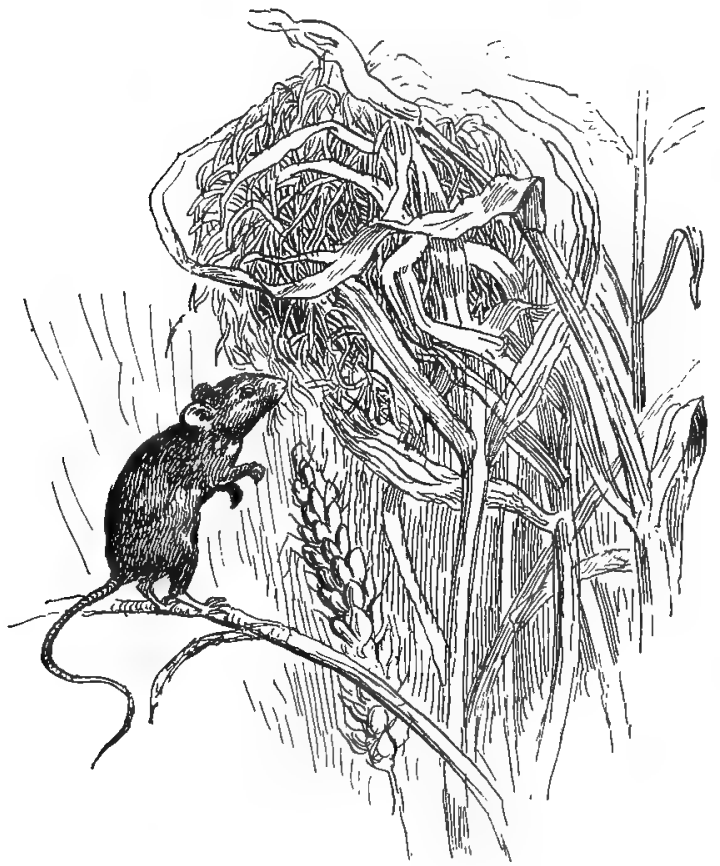

Nest of the field mouse.

man washing his funny wee face, or eating a kernel of corn, which is almost large enough to serve him for a meal. 
It surprises one to see how rapidly he can scamper over the ground, or climb shrubs and plants as cleverly as any monkey, running out on the slenderest twigs or upon leaves or stalks of grass so slight that they bend nearly to the ground, even with his sinall weight, generally in pursuit of flies, which are the game that harvest mice principally hunt; and it is worth while to see how swift his leap and sure his aim when he takes his prey.

His tail, it will be noticed, is the greatest possible help to him in climbing, for he not only employs it as a rope-walker uses a balance pole, but it is to some degree prehensile-that is, it can be employed to seize and to wrap around small twigs and branches to support him while he is climbing, in which he is also aided by the fact that the joints of his hind feet are so constructed that "they can be turned almost half around, which permits great freedom of movement."

There is something about some of these small animals that reminds one of birds. It is well known that there are individuals among the common mice that can sing like birds. Mr. Elliot Coues says, in the Standard Natural History :

"There is only one capacity of the house mouse to which I need allude, and that is its singing. $\Lambda$ mouse I once had presented to me was a great singer. Placing the cage in my bedroom, I turned off the gas and retired, to give it every encouragement to proceed with the expected programme in quiet and darkness, but with grave doubts that it would favor me with a song. In a few minutes, however, the little musician 
piped up and sang very prettily-it was not squeaking, but singing, musically and rhythmically, in a high key, with a thin and wiry but not displeasing quality - something like a weak-voiced canary bird.

"Listening for some time until I grew sleepy, I placed this eccentric prima donna in an adjoining room, at least twenty feet from my bed, the door open between, but even at that distance the singing was loud enough to disturb me, and I had to carry the little creature downstairs before I conld get to sleep."

Every sort of mouse makes nests, but those of the harvest mouse are the only ones not stuffed in holes or burrows, but built in regular bird fashion out in the open air upon plants or shrubs. They would certainly be mistaken by an ordinary observer for birds' nests, and very cleverly built ones at that, for the reeds and grasses of which they are made being carefully prepared, each leaf separated lengthwise by the teeth of the little builder into a number of threadlike strips, are skillfully knit together to produce firm elastic structures about the size and much the shape of goose eggs, and suspended at distances varying from a foot and a half to three feet above the ground.

The nest has no opening, and yet is so completely lined and filled with the softest vegetable materials to be had, that one is confronted with a problem with regard to the presence of from five to nine little mice inside, like that we are told so puzzled King George III about the apples in the dumpling, how they 
ever got there. Moreover, in addition to this, we wonder how their mother can feed them, or how the nest can contain them all as they grow larger, for they seem as closely packed away as sardines in a box. No doubt, however, impossible as it appears, the elasticity of the nest allows Mrs. Mouse to get through its meshes, and acconmodates the space inclosed to the needs of the little creatures within it.

At any rate, they all manage to escape from their close quarters as soon as they can see and are strong enough to provide for themselves, after which the mother gives them a few practical instructions in the art of making a living and then leaves them to their own devices. It is said by close olsservers of their habits that as they increase in age they improve in nest-building. 


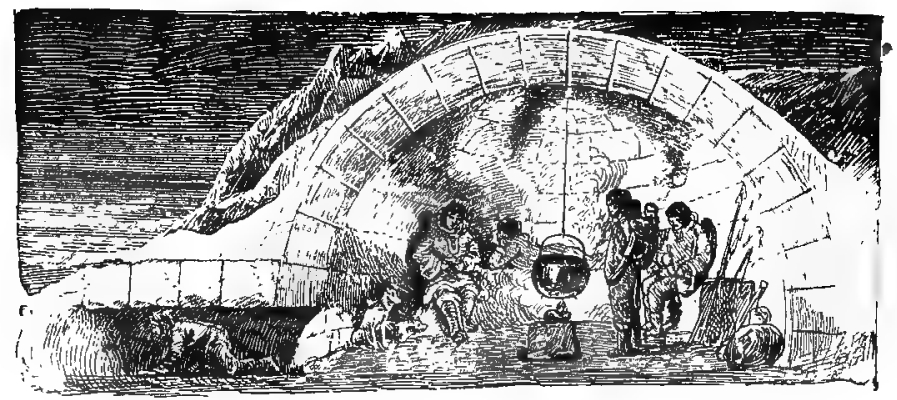

Interior of snow house of Eskimo.

HOMES OF THE ESKIMO, WHITE BEAR, AND SEAL.

NATIVE HOUSE-BREAKERS.

No country deserves its name less than does Greenland. If, indeed, it were called Whiteland or Snowland, as the island whose people first discovered it is called Iceland, it would be much more appropriately named. For more than half the year its hills are crowned with ice and its valleys filled with snow that even in the short summer time do not melt entirely away.

The Innuits or Eskimo who live in Greenland raise no crops; neither trees nor shrubs nor grass are to be found in this desolate region. In the dark winter time these people build their huts of snow. First tracing a circle on the ground they cut out slabs or bricks of snow to place around it and construct a house the shape of half a globe.

These houses are not cold, as might be expected; they shelter their inmates from the fierce aretic storms 
that blow from the arctic highlands, and never melt until the brief northern summer sets in, when they are replaced by others made of earth and hides of animals.

There are other inhabitants of Greenland that live in houses of snow-the bear and the seal. The former, at the beginning of winter, after looking about and finding a place suitable for her purpose, where the snow will blow and drift over her, lies down and

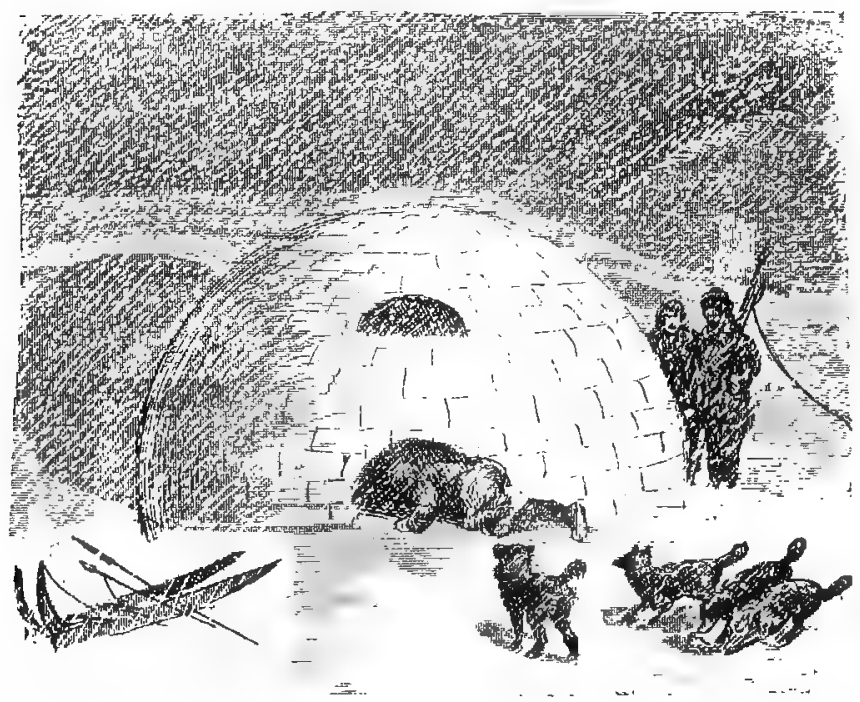

Silow llouse of Eskimo.

allows herself to be entirely covered. As this covering grows continually deeper, her breath and the warmth from her body gradually melt the snow about her 


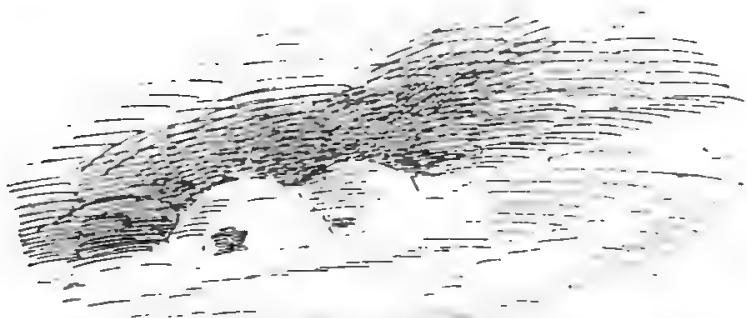

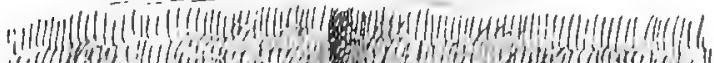

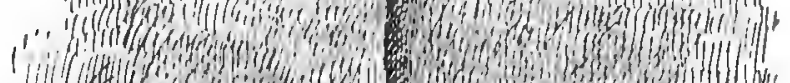

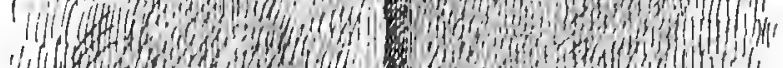

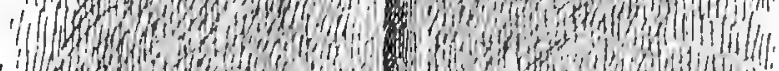

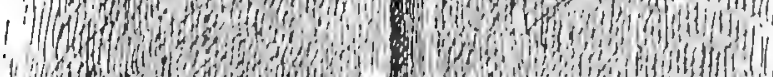

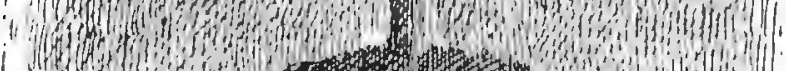

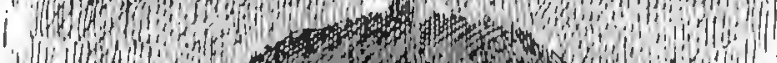

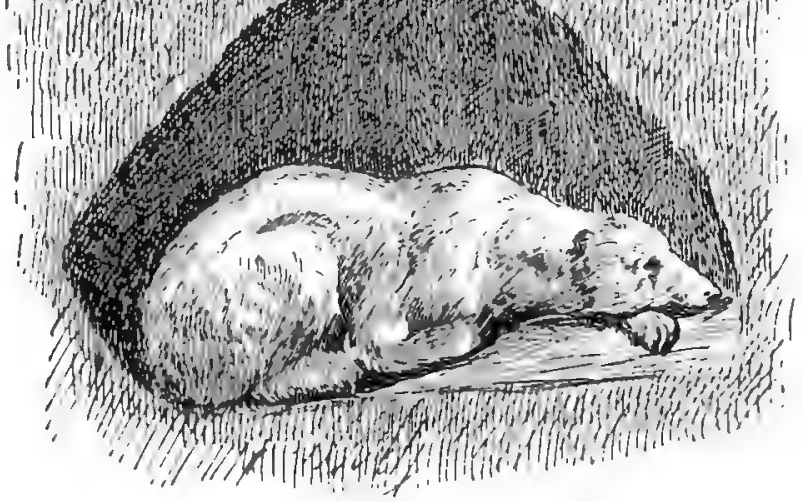
Snow house of polar bear.

until a hollow place is formed, in which she lives with her babies for three months without food or exercise. It is well that she is loaded with fat before she 13 
shuts herself up, for not only has she to sustain herself, but nurse her little ones; and, as may be imagined, it is a hungry family that makes its appearance in the early spring when the suow sofiens, and then mother bear dig her way out into the open air and into daylight.

It might perhaps be thought that any living creature buried in snow would smother, but not only is the snow itself full of air, but it permits air to penetrate through it; so much so that in a snow-house you can tell, by holding your hand near the wall, against which side the wind is blowing.

In this miscalled Greenland, the land of the midnight sun and midday moon, or where the whole year is divided into one day and night, where the winter's snows extent unbroken for unknown miles on every side, in vain might the traveler seek for any sign of life; and yet beneath his rery feet may lie a commodions dome-shaped apartment, where in comfort and safety reside a mother and her child.

It is the iylor, or house of the seal, who has taught the native Innuits how to build a comfortable (comfortable to Innuits and seals) home of no better material than ice and snow. In contriving a home for her little one, Madame Scal begins by enlarging the hole in the ice which is her door to the outer world.

Seals, although the greater part of their lives are spent in and under the water, are air-breathing animals, and consequently must have breathing-holes in the ice where they can at any tine procure a supply of oxygen. These breathing-places are carefully kept 
open through the winter, every fresh crust of ice being immediately removed, so that, no matter how thickly the surface is frozen, the door always remains open.

Having widened the opening with the aid of the sharp claws on her flippers; the same tools are brought to bear on the under surface of the snow, which thickly covers, to the depth perhaps of many feet, the frozen sea; and a dome-shaped chamber, exactly like the interior of the hut of a native, is scooped out before Madame Seal considers her work completed. The snow taken away in forming her chamber is conveyed by her under the ice, to be carried away by the water.

The baby seal, when it is born, occupies this hidden home, which is only revealed by the melting snows of summer, when its occupants have left it empty.

It is rery remarkable how the seal, having once left its hole to search for food, and chased through many and devious courses the fish upon which it feeds, can ever find its way back, in utter darkness and the complete absence of all landmarks, to its breathingplace, which it never fails to do, bringing with it the game upon which its little one feeds.

On rare occasions the two enemies against which all its precautions are useless when its location is discovered, invade the igloo and kill its defenseless inmates. These two enemies are man and the white bear; and their plan of capturing and killing the seals is exactly alike, except that man has to look to his dogs, while Bruin depends upon his own nose to inform him of the whereabouts of his prey. A slight, invisi- 
ble wreath of warm vapor perhaps issues from a tiny crevice in the snow. This is enough : it tells the bear all he cares to know of the dinner awaiting him under the heavy crust of frozen snow upon which he stands.

Closing his feet together in a bunch, he leaps into the air and brings his tremendous weight to bear upon as small a spot as possible. If not successful in breaking through, "Nennook," as the bear is called by the Innuits, will scratch away the surface and try again; lut, as might be conjectured, he seldom fails the first time in making his way through the roof of the igloo and descending upon its unsuspecting inmates.

When this takes place, the mother seal immediately plunges through the breatling-hole into the sea, and the bear, well knowing the uselessness of attempting to catch her, contents himself with first securing the baby, which is too young to follow its mother. Having done so, Nennook employs a very cruel stratagem to secure the old seal, using her maternal instinct to lure her to destruction. Hooking one of his formidable claws into the flipper of the little seal, he carefully lets it down into the breathing-hole and allows it to struggle and writhe about in the water beneath.

As the old seal anxiously approaches, he slowly and gradually withdraws the little one through the ice toward himself, until the poor mother, enticed within reach of the powerful claws of his other fore paw, is seized and secured. There is not the slightest 
doubt that the Innuits, who practice the same trick, have learned it of the bear, as they have learned their snow architecture of the seal itself.

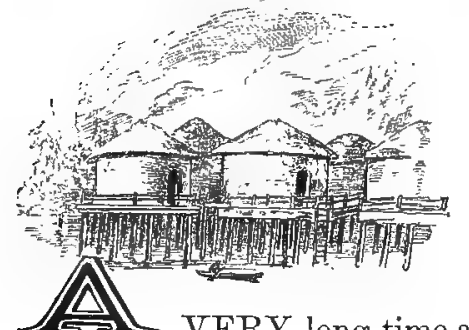

\section{HUMAN \\ LAKE-DWELLERS,}

ANCIENT AND MODERN.

5 VERY long time ago there were people in different parts of Europe who built what are called lake-dwellings, of which many remains have been discovered. These dwellings, constructed on platforms over the water, must have resembled those of tribes now found thousands of miles from Europe and from each other-in the Malay Archipelago, in New Guinea, and in South America.

How people who never heard of each other have learned to build their houses so much alike is a question that has never been answered. It seems quite natural that, as all birds of one species, wherever and whenever they construct nests, make them pretty much alike, so all savages belonging to the quiet, peaceful sort who live by fishing along the borders of lakes where they build their villages, are apt, as if by a sort of instinct, to build them in the same way.

In the settlements of the South American Indians on Lake Maracaybo, in Venezuela, the life of the an- 


\section{CULIOUS HOMES AND THEIR TENANTS.}

cient lake-dwellers can be seen almost exactly represented in perhaps every respect except one, and this is that every hamlet has its little church in the midst of the houses of the native villagers, built as they

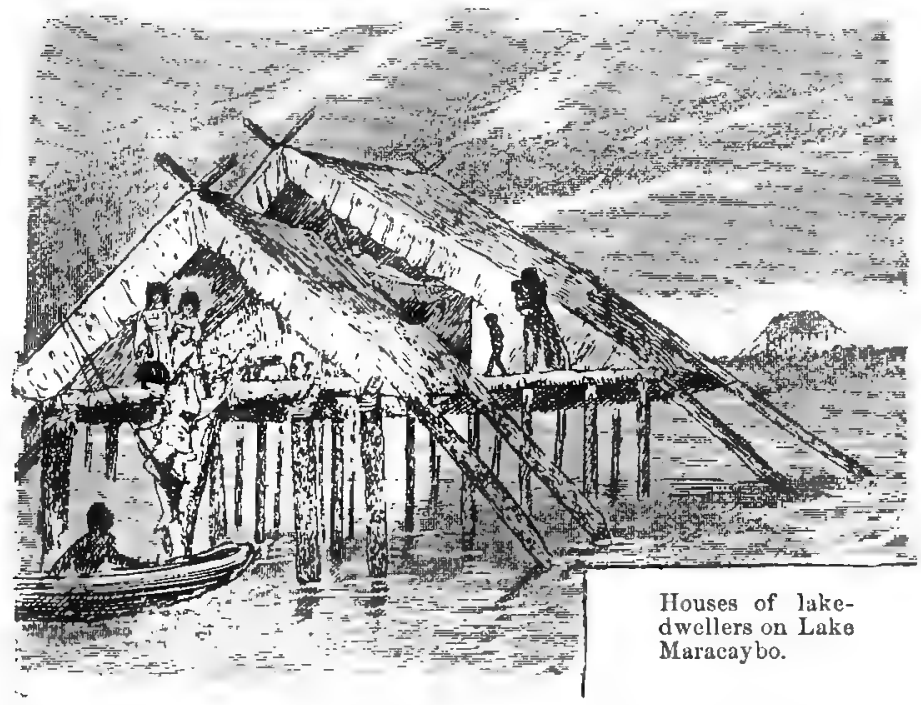

are upon piles, and surmounted by a belfry, which summons the fishermen before going out and on coming home from their day's labor to morning and evening prayer.

As you sit in these lake houses you can hear the water ripple underneath, and the children can fish from the open door or window, or can dive down from the platform on which the house is built and go 
swimming to visit their playmates. As it is always summer time in this part of the world, the water is never too cold to bathe in, and the fishing never fails.

The waters of Lake Maracaybo fairly swarm with beautiful and delicious fish. For instance, the lizi, a kind of skate of a silver-white color with blue shadings, is caught in abundance. It is rather a small fish, not much over a foot long, but it is excellent eating. A still more delicate fish is the pargo-white, tinged with rose color-and of these great numbers are taken. So, too, the doncello, or young lady (for that is what doncello means), is as pretty as its name, and so abundant that a part of the lake is named from it. The dorado, or gilded fish, is not red or white as are the goldfish kept in glass globes, but is really of the color and shines with the metallic luster of gold. It is taken with a hook baited with a white rag.

Many other kinds are caught, but the lake-dweller is by no means forced to live upon fish alone. In addition, his bow and arrow help him to a supply of the game with which the great forests that surround the lake abounds, and he sells the product of the Indiarubber trees that are sure to grow on the shore at no great distance from his dwelling, and buys cassawa, or corn bread, and whatever else he needs to supply his few and simple wants.

Why the lake-dweller inhabits such singular homes is a question that merits consideration. With dry ground and the firm earth close at hand, and just as 
convenient for all the requirements of his calling, why does he live where he can not get to his cabin without swimming or using a canoe? He would, by building on shore, save himself the severe labor of moving the heary piles on which his house is built, and of planting them firmly in their places under the water, which, it may be assumed, is no light task. Is it to secure a refuge against enemies or wild beasts? Doubtless it may have been so among the ancient people who first built in this way amid the cold rocks of Alpine solitude; but the Maracaybo fisherman seeks to escape other foes that render the shores of the lake quite uninhabitable. These are the mosquitoes, that are perhaps in no country in the world so formidable in numbers, so bloodthirsty, and so venomous.

Such insects, although produced in wet and marshy places, do not fly far from the land, and the lakedweller of Venezuela will tell you, if you ask him the reason for his building his dwelling so far out over the water, "It is simply to escape from the plaga de moscas" - the plague of ties.

In comparing the habitations of these human lakedwellers with the houses of beavers, we must confess that in some respects the beaver's house is more ingeniously contrived. In the first place, it is built of such material and in such a way that mere natural decay can never destroy its usefulness; in the next, it is so built that it is never likely to be blown down or destroyed by sudden storms; again, it is more secure from attack, the door being under the water, where it 
is less likely to be seen or entered by an enemy; and, lastly, the beaver contrives, by building his dam, to create a lake wherever he chooses, and he digs canals down which he floats the materials for his habitation.

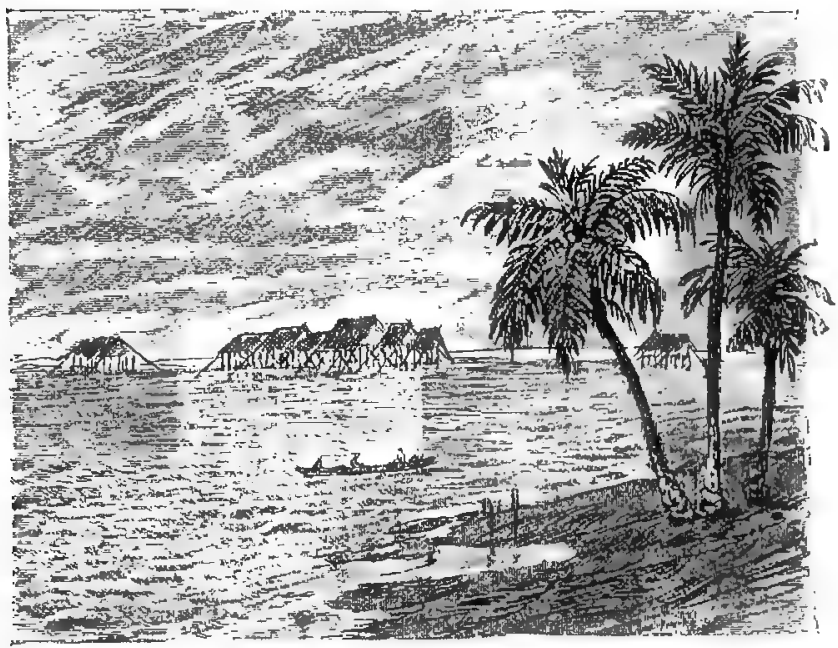

A hamlet of lake-dwellers on Lake Maracaybo.

FOUR-FOOTED LAKE-DWELLERS,

AND THEIR ARCHITKCTURE.

Of all mammals the beaver is the best housebuilder, and in some respects seems the most intelligent of the lower animals. There are, howerer, two sorts of intelligence among animals, without counting 
178 CURIOUS HOMES AND THEIR TENANTS.

the reasoning faculty that is proper to man alone. One belongs to an individual, and may be called individual intelligence. Such is the intelligence often exhibited by some particular dog, or horse, or monkey, or parrot, that renders them more teachable than their fellows, for this sort of intelligence can be always accurately measured by the capacity the animal possessing it exhibits to learn: the other belongs to the race, and may be called racial intelligence.

The capacity for learning in any of the lower animals is, comparatively speaking, small; it can not be carried beyond a certain fixed point. A parrot can not be taught to actually converse as does a human being, though the words it learns sometimes, among the very many times it uses them, may seem appropriate to the occasion; nor can a dog or monkey be taught to display the capacity for co-operation possessed by a bee or a beaver. Yet that a dog or monkey is individually more intelligent than a beaver no one can for a moment doubt. The beaver has the racial, the dog, horse, and monkey more or less individual, intelligence.

A human being knows almost absolutely nothing that is not tanght him ; a dog or monkey a great part of what it knows, and a beaver almost all that it can ever know, for a beaver individually is a rather stupid creature. The brain, which by its size and weight and the comparative number of its convolutions measures accurately the mental capacity of its owner, is in a beaver small and with few convolutions. The beaver, therefore, considered as an individual, is not 
intelligent, but as a member of a community is one of the wisest of mammals.

It is as if man had lost all his instinctive knowledge for the sake of gaining the ability to reason, and the beaver had bargained away all possibility of individual intelligence to gain more fully developed and perfect intuitive knowledge and instinct. If we suppose this to be the case, we may also suppose that this is where the beaver has made his mistake.

His instinct, it is true, is all that is needed to protect him against all his natural enemies and to fulfill all the requirements of his life. It has tanght him to build his houses of mud and sticks in the water, out of harm's way ; to make his door open at the bottom of the lake or pond in which he has fixed his habitation, into a passage upward that leads to a warm, dry, comfortable chamber beneath the thick, strongly built, domed roof of his house, where he can rest secure from all beasts or birds of prey, none of which have the art or strength to enter his fortress. It has taught him to lay up stores of fish, the bark and twigs and limbs of trees upon which he subsists; to build dams in order to keep the water at a proper height about his habitation, so that it will not freeze solid in the winter and imprison him in his house, or run.dry in summer and expose him to the attacks of his enemies. It has even taught him to dig canals in which to float the trees he has felled to the dam he is building; but it has not taught him to exist and hold his own, as does his humble cousin the muskrat, in the presence of man. 
Many races of valuable animals have been killed off until none remain. many more are on the way and traveling rapidly toward extinction, but certain species that have developed sufficient individual intelligence learn how either to successfully defy man or to gain his friendship and protection. Others have developed along lines that make them so easily domesticated and so useful that they, too, are preserred.

English sparrows, rabbits, rats, roaches, mice, and viler creatures live and multiply in spite of all that human beings can do to extirpate them. Dogs and cats are useful pets. Horses, cattle, sheep, and goats are indispensable, as are ducks and geese and poultry generally, but most of the wild races of animals are without doubt, with the beavers, doomed to become extinct.

Beavers are the only niammals that practice cooperation; others, like prairie dogs and viscarhus, live together in communities; lut no others work in common, as do beavers, for the benefit of the whole community.

The beaver colony select for its home a small stream running through a forest or grove of trees, consisting largely of willows, birches, and poplars, upon the bark and buds of which the animals feed. In order to get at the twigs and fresh shoots from the limbs, of which they are very fond, the animals cut down trees of almost all sizes.

They do not, however, as is reported of them, fell the trees in such a manner as to make them fall into the water, where they can float them to the spot 
selected for their dam. The trees are cut down by gnawing all around the trunk with the large, chiselshaped teeth of the animal, and gradually deepening the cut until the tree stands upon quite a slender portion of its substance-the trunk above and below assuming the form of an hourglass, or two cones united at their slenderest part. The smaller saplings and the branches of the larger ones are, when the trees fall, cut into lengths of five or six feet, which after the bark has been eaten off are employed in strengthening their dam or building their lodges. The lodge is oven-shaped; its walls are very thick, made of mud, strengthened with sticks of every size and shape. It is from six to eight feet in height, and measures from twelve to twenty feet in diameter. It contains a chamber sometimes seven feet across and between two and three feet high; the floors of this apartment are covered with dried grass, chips, and the soft bark of trees, that form a bed for its occupants. The dams built by beavers are sometimes four hundred and fifty or even six hundred feet in length.

\section{A FLOATING NEST.}

Wet, cold, and unclean-looking, a mass of rotting weeds that appear to have casually floated together, as objects in still water have a tendency to do, such is the nest of the crested grebe, certainly the most uncomfortable-looking nest in the world. It may be in one place in the morning, and blown away over the 


\section{CURIOUS HOMES AND THEIR TENANTS.}

surface of the water to quite another before the day is past; for it floats, though how such a water-soaked lump of vegetation can float is something of a mystery: perhaps the gases evolved in the decay of its constituent parts buoy it up. It is still more of a mystery that it does not capsize as the large, heavybodied grebe steps off or climbs out of the water upon it. She must trim ship very expertly to prevent such an accident.

But its peculiar construction answers one purpose very well. Even if any one recognized it as a nestwhich is rather unlikely - he would imagine it was not tenanted, that it was probably a last year's empty nest; for the four or five wet and dirty eggs, white when first laid, but afterwild stained an impure yellow, are sure to be corced with part of the rubbish of which the nest is composed.

As for catching a grebe sitting on her nest, that is well-nigh impunilule. The grelis, both great and small - there are two kinds - are the most circumspect of hirds, keeping as far as possible in the open water, where objects can be seen at a distance, and listening so intently and with such a keen sense of hearing that the launching of a boat half a mile away is enough to alarm them.

Still, there have been naturalist detectives who have succeeded in shadowing them and finding out their secrets and studying their habits, wary as the birds are. It is to the skill and patience of such men that we owe all we know of the lives of the wilder nuembers of the animal kingrlom. 
One of these students of Nature, Professor Jäckel, describing the little brood just after they have emerged from the egg, writes:

"It is a treat to watch the little family as now one, now another of the young brood, tired with the exertion of swimming or of struggling with the rippling water, monnt, as if upon a board or a little boat, their mother's back; to see how gently, when they have recovered their strength, she returns them to the water; to hear the anxious, plaintive notes of the little wanderers when they have ventured too far from the nest; to see their food laid before them by the old birds; or to witness the tenderness with which they are taught to dive. It is only after they are eight days old that they are strong enough to enter upon this last important part of their education, which is commenced in the following manner:

"The mother bird first swims toward her little flock two or three times, holding in her beak the proffered food; but as they advance to receive it she gradually retires before them, and at last dives with it, thus tempting the timid little creatures to follow her, and always at the end of the performance allowing the best swimmer to obtain the tempting prize as a reward for its exertions."

As may well be imagined, no bird that flies is more thoroughly aquatic than the grebe. It can scarcely be driven to take flight, though when it does fly, its progress through the air is straight and rapid, and accompanied with a loud, whirring noise that can be heard at quite a distance. If surprised and pur- 


\section{CURIOUS HOMES AND THEIR TENANTS.}

sued, the bird dives, and, as it can swim under the water two hundred feet in the course of half a minute, and when it comes to the surface to breathe can keep its whole body submerged, only allowing its beak to appear above the surface before it dives again, and can repeat the operation as often as occasion calls for, it is pretty sure to escape-much more so than if it took wing.

Papa and Mamma Grebe are an extremely attached couple. If one by any accident strays to a distance, the lake resounds with the anxious cries of the other calling the wanderer back again; and if the truant bird is within hearing - it must have gone a long way off if it is not-it hastens to the side of its mate, and the two, swimming together side by side, utter the fondest notes of mutual endearment as they playfully caress each other.

Though rather ungainly-looking fowls away from their native element, they are handsome birds on the water, with their boat-shaped bodies, long, slender necks, and small heads; their plumage is dense and thick, and upon the lower part of the body as smooth and glossy as satin. They have also their wedding ornaments. When they mate, a curious collar or frill makes its appearance along the side of the face and neck, or in some species tufts of feathers decorated with bright colors.

No birds live so exclusively upon the water as do grebes, for it is only by the rarest accident that they ever make their appearance on shore.

The lake on which they live not only furnishes 
them their daily bread in the form of tadpoles, little fishes, frogs, and aquatic insects, but a bed on which, while other birds are roosting high in air on the trees, they rest, floating lightly as a cork, their legs drawn up to the edges of their wings and their heads and necks comfortably buried in their plumage between their back and shoulders, and quietly sleep.

\section{A WEB-SPINNING FISH}

AND HER NEST.

Among nest-making fishes the oddest-looking, without exception, is the antemnarius. A celebrated naturalist says of it:

"It is one of those strange wild forms that sometimes occur in Nature, and which are so entirely opposed to all preconceived ideas, that they appear rather to be the composition of human ingenuity than beings actually existing. The traveler who first discovered this remarkable fish would certainly have been disbelieved if he had contented himself with making a drawing of it, and had not satisfied the rigid scrutiny of scientific men by bringing home a preserved specimen."

Not only do these fish differ from all members of their family of other species, but they vary so extremely among themselves that hardly two specimens are found sufficiently alike in form and color to en- 
186 CURIOUS IIOMES AND THEIR TENANTS.

able the naturalist to determine their exact position in the zoölogical scale.

Whether the habit is shared by varieties of this fish to be found elsewhere is not known, but those

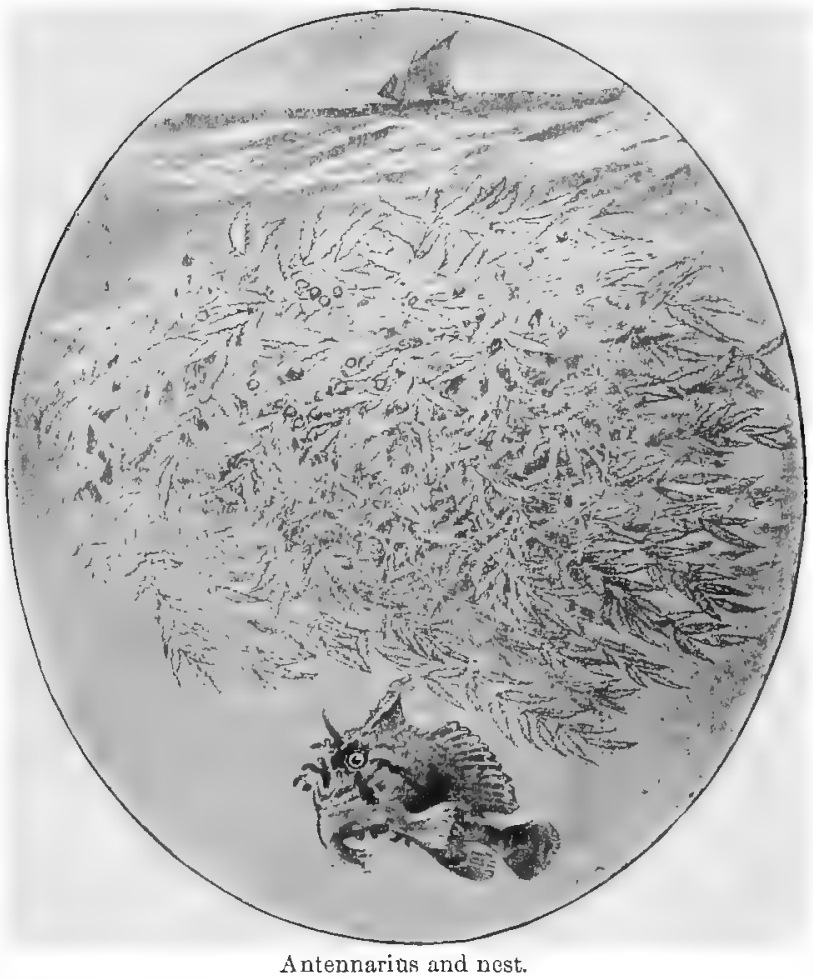

frequenting the Gulf Stream, off the coast of North America, build themselves nests of seaweed, in which their egggs are hatched. These nests consist of large, 
globular masses of gulf weed, filled with the spawn of the antennarius, and bound together with threads of glutinous matter spun by the mother fish.

\section{QUARRELSOME LITTLE NEST-BUILDERS.}

HOW THEX PROTECT THEIR YOUNG.

If the edges of ponds and creeks in most parts of our country are carefully examined during the spring months, numbers of bright, active little fish may be. seen busily engaged in building their nests-for many kinds of fish, as well as birds, build nests.

Having found a suitable bit of grass or straw, the fish seizes it and fits the tiny fragment in its place, after which it busies itself, for perhaps half a minute, in securing it with a sort of web that the fish can spin, so that it will not be washed away.

The bottom of the nest is first laid down, then the sides and the top are built, and when it is finished it is so nearly the exact color of the ground at the bottom of the water that it is no easy matter to find it, unless the eggs are visible or the fish itself is at work. The whole structure is a little larger in circumference than a silver quarter of a dollar, and has a top or cover with a small hole in the center where the eggs, which are about the size of poppy-seeds and of a bright yellow color, are placed. This opening is sometimes, but not always, concealed by dragging small fragments over it. 
16'S CURIOUS HOMES AND THEIR TENANTS.

When the nest is taken from the water it does not fall apart, but hangs together like a piece of wool or

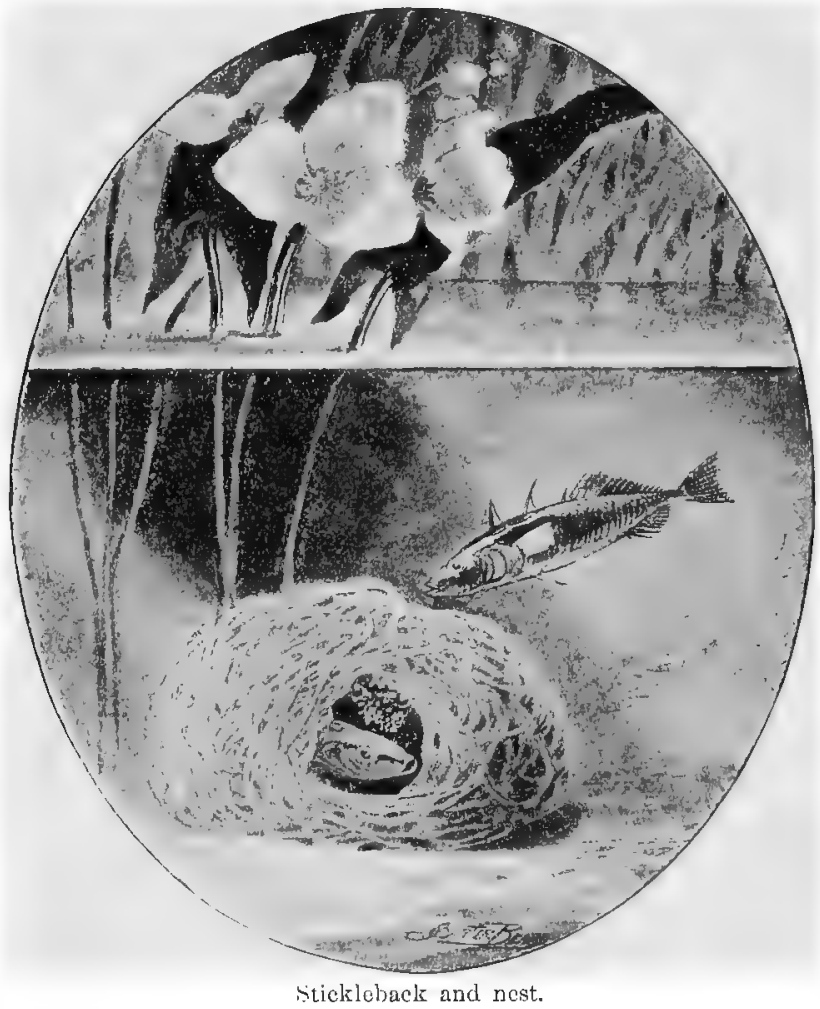

cotton. The eggs whon about to hatch darken in color, until they are almost black.

For a whole month the brave little fish remains on guard until the young ones are old enough to take 
care of themselves, and woe be to the intruder that dares approach too near! The male fish immediately dashes at it and attacks it with the utmost ferocity; a terrible battle ensues; the combatants swim round "and round each other with the greatest rapidity, biting and trying to pierce each other with their spines, which stand erect like sharp thorns upon their backs, and with which they sometimes succeed in ripping open and killing their opponents.

When kept in glass tanks and aquariums these little fish are a source of much interest and amusement, though, as may be supposed, it is better to let them have a tank to themselves, and not to introduce other and more peaceful fish to share it with them.

There are various kinds of these fish, called, after the number of spines upon their backs, three-, five-, ten-, and fifteen-spined sticklebacks. The fifteenspined stickleback lives in the sea, and makes its nest of seaweed or coralline. It has the same habit of guarding its eggs as the fresh-water species, and is quite as quarrelsome. The threads spun by the fifteen-spined stickleback resemble silk, but how the fish spins them has never yet been discovered.

\section{A DOME BENEATH THE WATERS.}

Among all aquatic homes of man or animals, the strangest and most interesting is that of the water spider, who makes her house with silken walls under 
the surfare of the water, fille it with air, and lives in it as in a diving bell.

Iler lome is eng-shapenl, almut the sizo of an

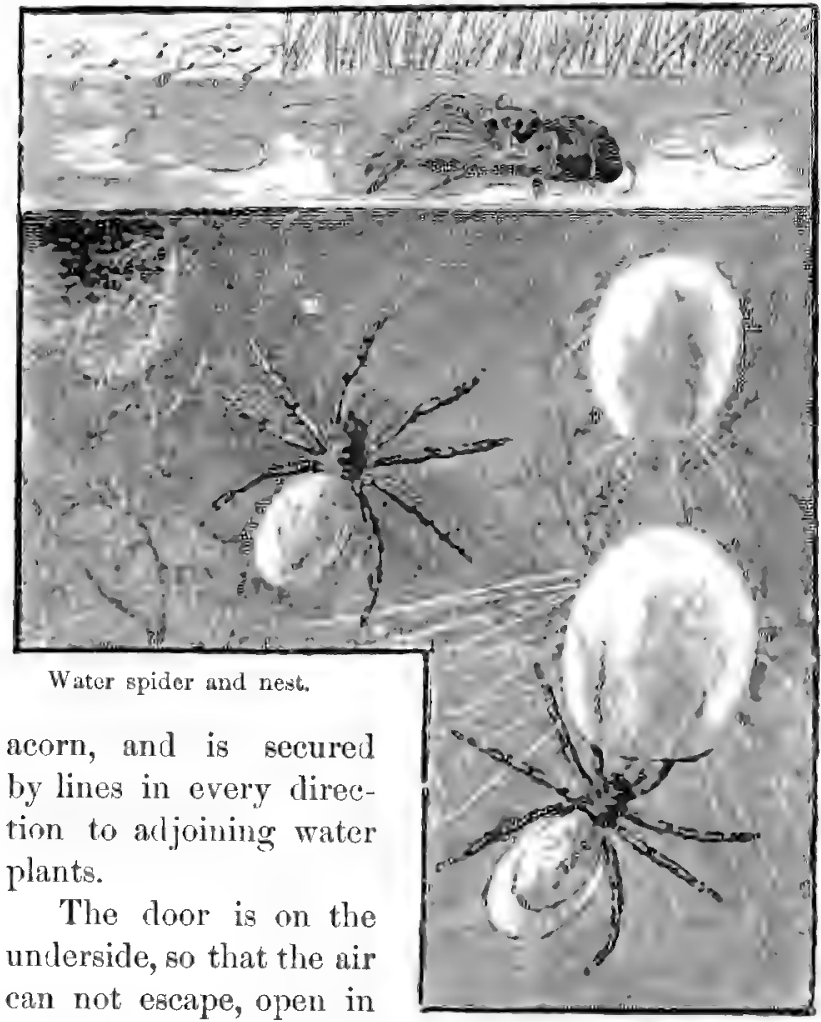

the summer time for the

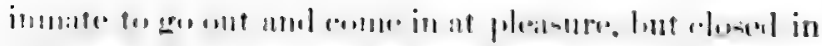

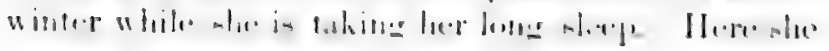


brings her prey to eat it, and here she places her eggrs, spinning a sancer-shaped cocoon and fixing it against the inner side and near the top. In this cocoon are about a hundred eggs, round as bird-shot but very much smaller.

Here the young spiders are born, and here they remain until they are large and strong enough to take care of themselves, when they are turned adrift by their mother to construct other subaquatic houses similar to those in which they first drew breath. Mr. Thomas Bell, the English naturalist, first observed and described the manner in which the spider manages to fill her dome with air.

"The one now referred to," he says, "began to weave her beautiful web about five o'clock in the afternoon. After much preliminary preparation she ascended to the surface and obtained a bubble of air, with which she immediately and quickly descended, anil the bubble was disengaged from the body and left in connection with the web. As the nest was on one side in contact with the glass, I could easily observe all her movements. Presently she ascended again and brought down another bubble, which was similarly deposited.

"In this way no less than fourteen journeys were performed, sometimes two or three very quickly, one after the other; at other times with a considerable interval between them, during which time the animal was employed in extending and giving shape to the beautiful transparent bell, getting into it, pushing it out in one place and amending it in another, and 
strengthening the attachments to the supports. At length she scemed satisfied with its dimensions, when she crept into it and settled herself to rest with the head downward. The cell was now the form and nearly the size of half an acorn cut transversely, the smaller and rounded part being uppermost.

"The manner in which the spider possesses itself of a bubble of air is very curious. She ascends slowly, assisted by a thread attached to a leaf or other substance below and to some object on the water. As soon as she comes near the surface she turns with the extremity of the abdomen upward, and exposes a portion of the borly for an instant to the air, then with a jerk snatches, as it were, a bubble of air, which is not only attached to the hairs that cover the abdomen, but is held on by the two hinder legs, which are crossed at an acute angle near their extremity; the crossing of the legs taking place the moment the bubble is seized.

"The little creature then descends more rapidly, and regains its cell always by the same route, turns the abdomen within it and disengages the bubble by opening ler hind feet and letting it go." 


\section{TUBE DWELLINGS,}

AND THEIR BUILDERS.

The caterpillars of the caddice flies build themselves little portable dwellings of sticks, grass stems, small shells, and such matters, which they drag about after them over the bottom of the pond or stream in which they live, as hermit crabs do the shells they inhabit beneath the surface of the ocean.

Some of the tubes of the caddice worms, however, are fixed, in which case they resemble not so much the hermit crab as the so-called marine worms.

These marine worms, though called by that name, do not in the least resemble anything we commonly know as worms, the emblems of abasement and helplessness; on the contrary, they hold themselves erect in the handsomely constructed tubes they build, and sit like kings upon their thrones, wearing magnificent crowns of gemlike brilliancy and splendid color. These crowns are their gitls or breathing apparatus, and also serve to convey food to their mouths. Each of the rays that form the crown or gill tuft consists of a translucent stem, from which springs a double row of secondary rays like the teeth of a comb.

When looked at with a magnifying glass, the red blood may be seen coursing along the artery and back again by the veins with ceaseless motion, forming a very striking spectacle. The rays or filaments are 


\section{CURIOUS HOMES AND THEIR TENANTS.}

beset with strong bristles called cilia, that are continually in motion, sweeping the water against the gills

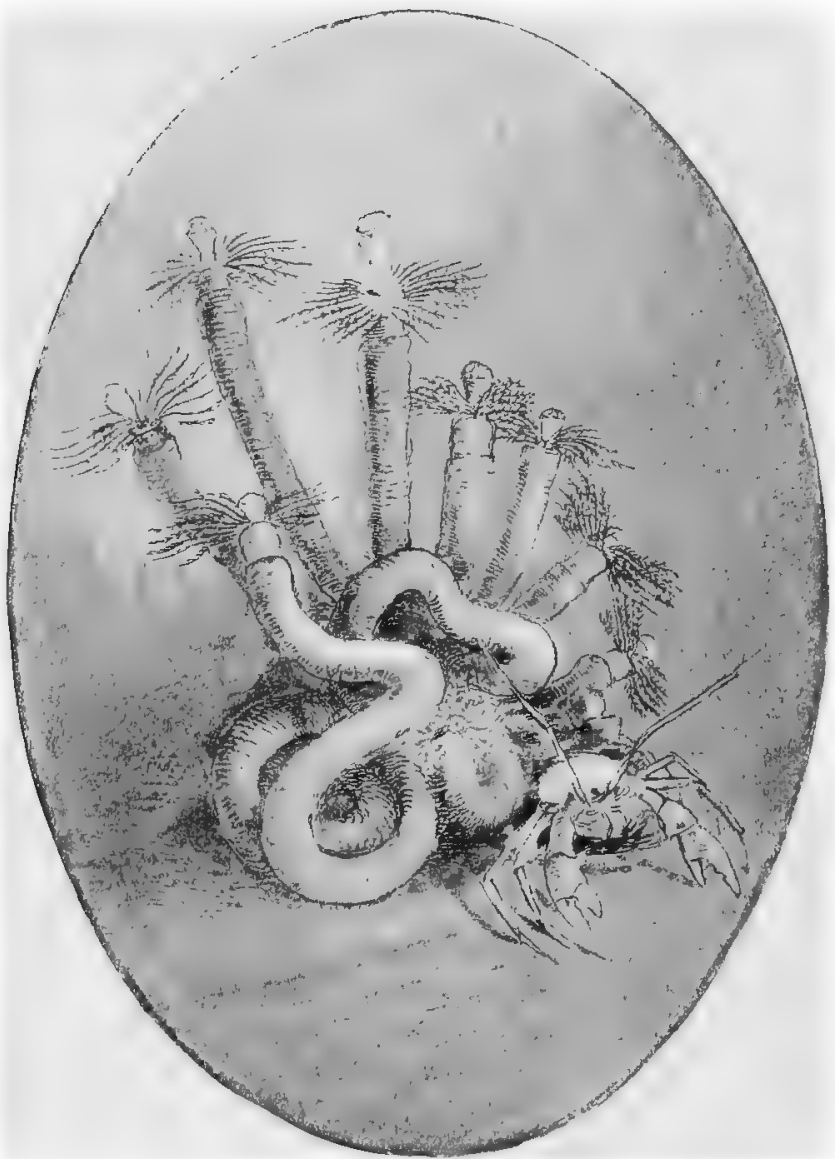

Tube dwellings of serpula. Ifermit crab inhabiting tube of dead serpula. 
and furnishing them the requisite amount of air they have the power of extracting from the current and carrying the water down into the mouth, which opens at the bottom of the gill tufts. In the water is always a sufficient supply of minute marine animals to furnish the. serpula, as this worm is called, with the food it requires.

The tube it inhabits, like the tube of the trapdoor spider, has a lid. This is called an operculum, from a Latin word meaning a cover or lid.

The serpula, which gets its name from the serpentlike coils in which its tube is constructed, seems to be built on the reverse principle to that of a Jack-in-thebox, which is always ready to startle the spectator with his sudden appearance, but has to be forced back into his box, while the serpula comes ont of its tube very slowly and cantiously, but on the slightest alarm vanishes with lightninglike rapidity back into it, clapping its door shut after it. As the tube is from six to ten times the length of the animal that made it, the serpula has a deep and safe retreat.

It withdraws itself into its shell by means of an array of hooks on the upper part of the body, extending half across the back, that catch into the membrane that lines the tube. These hooks are fastened to long threadlike sinews, by means of which they can be unfastened as well as fastened to the interior surface of the tube.

There are a great number of species and varieties of these beautiful marine worms, some of which contrive to form of mud and a secretion from their bodies tubes almost as tough and elastic as India rubber. 


\section{SEA SHELLS THAT BUILD NESTS,}

AND SUIE THAT HAVE MADE HWMUA IN THE MARBLE PILLARS OF A TEMPLE.

If it be thought surprising, as it must be to any one who cousiders the matter, that birds with no better appliances than their beaks-as they do not use their claws for the purpu-e-ilre (apuble of perfirming the delicate work neessing in constructing some of the more wonderful masterpicess of bird architecture, and that mammals, reptiles, inserts, and even crusticea and fish build burrows and nests, what must be thonght of sea shells that do the same thing?

At tirst sight an ordinary smuffbox, if life and the power of opening and closing its lid were crrmter it, might seem ats well epuipped for construeting the peruliar and beatiful nest of the Limm hiomin, or excavating in solid gneisis or prmite the burrows of the pholis, as thrse bivalves themselves. How is it done? Ah, that secret belongs to them, and they have never divulged it to mortal nen. It is a prize puzzle, and lucky the concholonist who solves it iml can prove that he has done so; he will make lis reputation.

The lima is a leantiful shell. It is oval-oblique, and opens anteriorly. The elge of the mantle is fringerl with long. trailing proreseses of a redelish swolien color, thit float lehind it like the tresses of 
a mermaid as it swims through the water. Swim? Certainly it can swim, or better, perhaps, fly through the water, using the two valves forming the shell exactly as some butterflies of the extensire genus Pamphilu, popularly called "skippers," from the short, jerky character of their flight, use their wings.

Then resting upon the sea bottom the lima opens wide the valves of the shell, as these butterflies do when basking in the sun, but when disturbed flaps its light shells and darts amar. As the shellfish settle quietly on the bot-

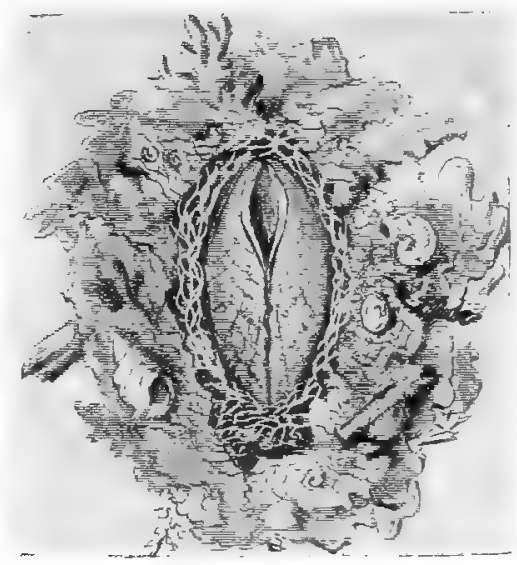

Lima : a sea shell that builds a nest.

tom again, ther "anchor themselres securely," sars Prof. Kingsley, describing them, "by means of their provisional brssus, which they seem to fix with much care and attention, previously exploring every part of the surface with their extraordinary leechlike foot."

The byssus, it may be remarked, is a most singular provision of Nature, a silky bundle of fibers, from which the historian Gibbon said the old Romans wove a costly fabric. This tuft of long filaments is formed by a gland in what is called the foot of the 
mollusk, and, issuing from between the valves of the shell and fastened to rocks, etc., serves to anchor this animal in its place. How the filaments are fastened has, I believe, never been explained. The nest of this intelligent pecten is formed of coralline shells and sand cemented together.

The pholas, another nest-building shell, besides the ability it exhibits of working its way into solid rock, in which it hollows out its habitation, has other interesting properties. It is very good to eat, for one thing, being esteemed a great delicacy in some parts of the British Isles, either cooked or uncooked. Eng-

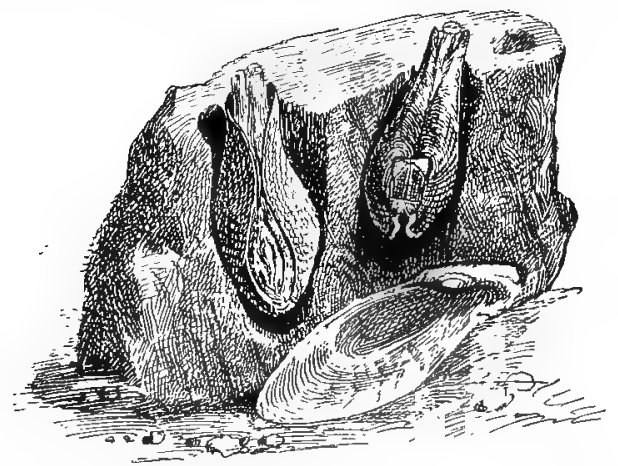

The pholas in burrows which it has excavated in granite.

lish people call it piddock, and the pidlock fishery is of no small account in their eyes. But that which gives it the greatest luster in the eyes of the naturalist is its luminosity.

Many mollusca have more or less phosphorescence, but none, so to speak, can hold a candle to the pholas, 
either dead or alive. It slines in the dark with a bluish-white light of such intensity that one immersed in milk has served for a sort of lamp, lighting up the faces of those about it; and of such permanence that one kept in honey remained luminous for over a year. Indeed, an eminent naturalist, speaking of eating this mollusk, says: "Those who eat the pholas would appear in the dark as if they were swallowing phosphorus. A fisherman dining on this delicacy appeared to be giving them an exhibition of fire-eating on a small scale." The perforations produced in stone by this mollusk have furnished important testimony of the sinking and upheaval of the earth during the present geological period. "Pozzuolo," says the author of The Ocean World, "in Italy, touches on Solfaterre on the Lake Avernus, and is not far from Vesuvius, and in the bay is that monument of other days erroneously called the Temple of Serapis. It was probably a thermal sanitarium, established for its mineral waters, although the world has now agreed to call it a temple. However that may be, the building has been nearly leveled by the hand of Time, aided considerably, no doubt, by the hand of man, and the ruins now consist of three magnificent columns about forty feet high. But the curious and important fact is that these columns at about ten feet above the surface are riddled with holes and full of cavities bored deeply into the marble, occupying a space of about three feet on each column.

The cause of these perforations is not doubtful. In some of the cavities the shell of the operator is 
200 CURIOUS HOMES AND THEIR TENANTS.

still found, and it is settled among naturalists that it belongs to a species of pholas.

To enable the stone-boring mollusks, which live only in the sea, to excavate this marble, the temple and columns must have been immersed at least twenty or thirty feet under water.

It is only under such conditions that the borers could have labored at their ease in the marble columns. But since these perforations are now visible ten feet above the surface, it is evident that after having been a long time immersed under water the columns have been elevated to their present position. The temple restored to its primitive elevation carries with it, engraved in the marble, ineffaceable proofs of its immersion.

\section{A HEAD-FOOTED NEST-BUILDER.}

HOW SHE CARES FOR HER EGGS.

That there should be anything at all in the way of nest-building connected with the life history of such a creature as the devilfish, or octopus, seems sufficiently incredible, but that it should guard and care for and watch over its eggs until hatched appears even more so. The animals that live in some sorts of sea shells build nests, but we must look much higher in the ranks of organized creation to find anything like care excreised for eggs or young, except in the 
case of the octopus, which has been gifted with sense and passion far beyond any other mollusk.

In trying to get some comprehension of the remarkable anatomy of these creatures, it may help us to imagine some monstrous form of man or beast in which the body is so bent that its extremities are brought close together, and the limbs surround the head. Instead of four, however, an octopus has eight limbs; these serve both as legs to walk upon or arms to grasp and carry substances or grapple with enemies or capture prey. They are, in fact, like eight strong, flexible serpents united at one extremity to one head and body, but far more formidable than serpents, because they each have their under surfaces provided with rows of disklike suckers, that take hold with such force and hold on with such tenacity to what they have grasped that nothing short of tearing to pieces the limb by which they retain their hold will induce them to let go their hold.

The head is provided with a strong, horny beak like that of a parrot, and large and brilliant eyes that well express the keen alertness and savage activity of the creature.

Besides their limbs, by the aid of which octopods can swim and walk head downward on the bottom of the sea, they are provided with a fleshy tube through which they can force a stream of water that sends them backward. In some species of cephalopods or head-footed animals this can be done with such violence that they shoot like arrows through the water, and even, it is said, like the flying fish, take long, 
curved flights through the air, so as occasionally to throw themselves aboard or over the deck of passing vessels.

When any of the arms of a devilfish have fastened upon living prey, it is at once brought to the mouth and pitilessly crushed in its powerful jaws, whose cutting edges fit one over the other like those of a tortoise.

Nature has also provided this formidable creature with an additional means of defense in the power of ejecting a fluid of inky blackness in sufficient quantity to form a thick cloud in the water and thus conceal itself from its foes. It is of this dark liquid that the sepia paint, so much used by water-color artists, is made. Mr. Henry Lee, in his Aquarium Notes, says, concerning the octopus:

"Our octopus fortunately selected as a suitable site for her nest a recess in the rock work close to the front glass of the tank, so that her movements could be easily observed. Her body just filled the entrance to it, and she further built it and strengthened its defenses by dragging to the mouth of her cavern more than two dozen living oysters and piling them one upon another, to form the outer wall of her nest, and serve as a breastwork or barricade, behind which she ensconcell herself.

"Over this rampart she peered with her great, sleepless, prominent cyes; her two foremost arms extended beyond it, their extremities cuiling and writhing in ceaseless motion, as if prepared to strike out right and left at any intruder. Her companions evi- 
dently thought it dangerous to approach an excited mother guarding her offspring, and none ventured to go within arm's length of her. Even her forlorn

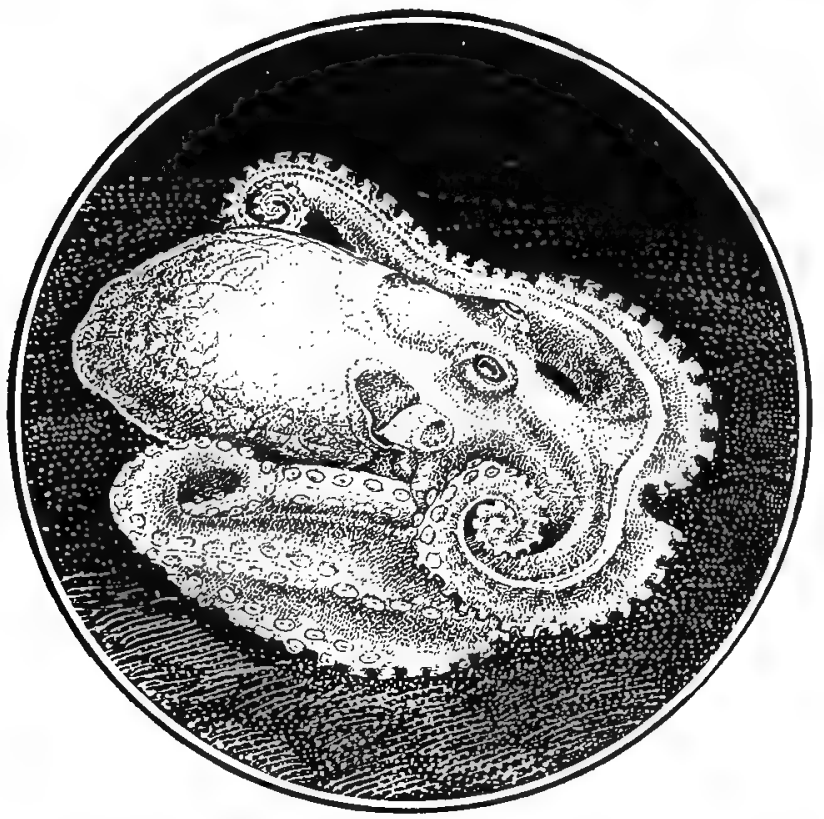

The octopus at rest.

husband was made to keep his distance. If he dared to approach to whisper soft words of affection into his partner's ears, or to look with paternal pride upon the newly-born infants, the lady roused herself with menacing air, and slowly rose until her head overtopped the barrier.

"By an instantaneous expansion of the pigment 


\section{CURIOUS IIOMES AND THEIR TENANTS.}

vesicles a dark flush of anger tinged the whole surface of the body; the two upper arms were uncoiled and stretcled out to their utmost length toward the interloper; and the poor, snubbed, henpecked father, finding his nose put out of joint by the precious babies which belonged as much to himself as to their fussy mother, invariably shrank from their formidable contact, and sorrowfully and sullenly retreated, to muse, perhaps, on the brief duration of cephalopodal marital happiness.

"The eggs of the octopus when first laid are small, oval, translucent granules, resembling little grains of rice, and not quite an eighth of an inch long. They grow along and around a common stalk, to which every egg is separately attached as grapes form part of a bunch. Each of the elongated bunches is secured by a glutinous secretion to the surface of a rock. . . A large octopus produces in one laying, usually extending over three days, a progeny of from forty to fifty thousand.

"Our brooding French octopus when undisturbed wonld pass one of her arms beneath the liunging bunches, and spreading out the louse skin on both sides of it into a koat-shaped hollow, would gather and receive them into it as into a trough or cradle; then she would caress and gently rub them, occasionally turning toward them her flexible tube like the nozzle of a fireman's hosepipe, so as to direct upon them a fresh jet of water. I believe the object of this syringing process was to free them frum the errers of parasitic animalcules, and possibly to prevent the 
growth of conferva (water plants), which I have found rapidly overspread those removed from her.

"W eek after week she continued to attend on them with the most assiduous care, seldom leaving them for an instant except to take food, which she could not otherwise procure, but which having secured she immediately returned.

"The young octopus fresh from the egg is about the size of a large flea, and when irritated is much the same color. It is very different in appearance from an adult individual of the same species; the arms, which will be four or five times the length of the body when the octopus is fully grown, appear only as little conical projections, having points of hair-like fineness, and arranged in the form of an eight-rayed coronet around the head.

"At this early stage of its existence the young octopus seeks and enjoys the light, which it will later in life carefully shun. It manifests no desire to hide

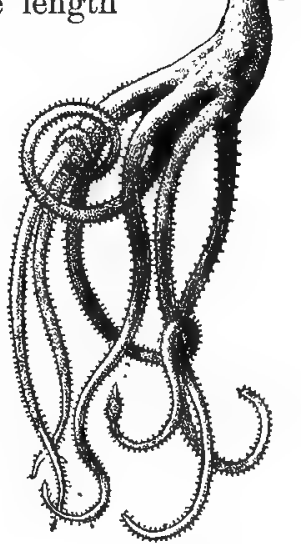

Living hydra. itself in crevices and recesses as the adult does, but swims freely about in the water, often close to the surface, propelling itself backward by a series of 
little jerks caused by each stroke of the force pump, which expels a jet of water from the ontflow pipe of the siphon."

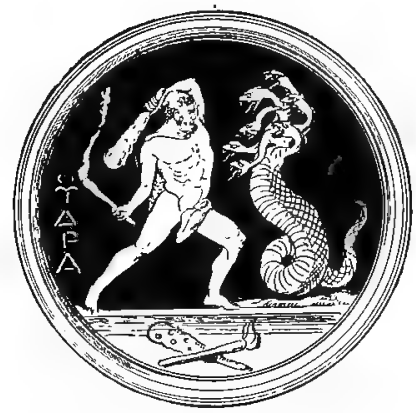

IIercules clestroying fabled bydra.

\section{AN ANIMAL ROLLED INTO A BALL,}

THAT LIVES IN THE SOLID ROCK.

A sea urchin does not look very unlike a small hedgehog or porcupine ant-eater that has rolled itself, as these manimals are sometimes in the habit of doing, into a prickly ball. It must, however, be confessed that an important difference exists in the fact that hedgehogs and porcupine ant-eaters can unroll themselves, while a sea urchin is no more able to do so than the chestnut burr he so much resembles.

Bring all the points of a five-fingered starfish together, fill up the spaces left empty with substances similar to those of which the starfish is composed, and 
you have the sea urchin without its prickles; or, take a chestnut burr, divide it in to five equal sections, spread it open, and you have a representation of a sea urchin as it would appear transformed into a prickly starfish.

The shell of a sea urchin is one of the prettiest objects to be found on the seashore, looking, as it does, like some elegantly ornamented curio or globe-shaped casket made up of a great number of hexagonalshaped plates, each one decorated with large and small buttons or bosses.

This shell, unlike those of crabs and lobsters and many other sorts that protect shellfish and insects and

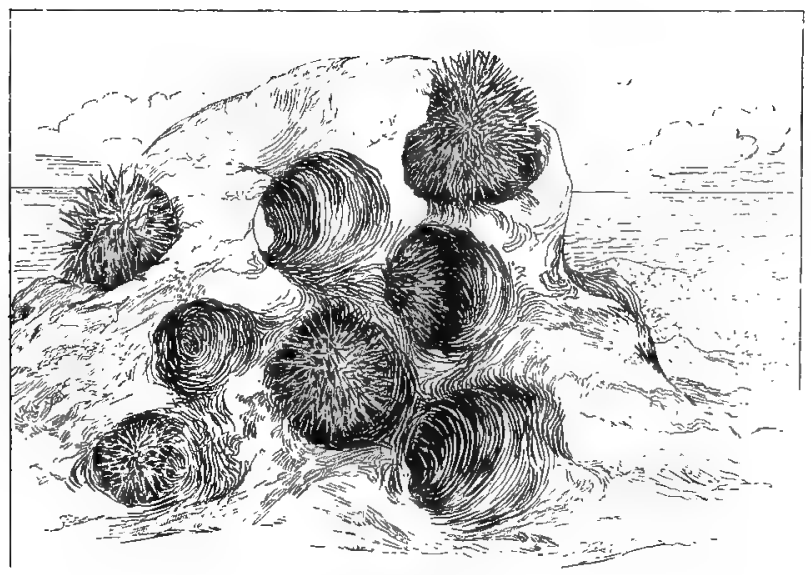

Sea urchins embedded in solid rock.

the animals it clothes, grows larger, is cast off and replaced by another, must remain upon the sea urchin as long as it lives, and the question, of course, at once 
arises how it can be made to accommodate any increase of size on the part of the individual it incloses? In fact, an entire hard crust would not be capable of distention, and it immediately is made plain that what seems elegant ornamentation on the sea urchin's shell, for the sole purpose of making it look pretty, is, in fact, a peculiarity of structure alsolutely indispensable to the requirements of the creature's growth.

As the sea urchin increases in size, continual deposits of chalky matter are made on the edges of the many pieces of which the entire shell is composed. These parts thus keep their shapes though their size enlarges. The work is done by a delicate skin which covers the whole surface of the shell and the prickles or spines, and, closely joined together as they seem to be, penetrates between the separate plates and pushes them apart by the additional material it inserts between them.

It also forms the spines, and in a wonderful manner effects their union with the shell they cover ; each spine working in a ball-and-socket joint, the ball being one of the buttonlike bosses which ornament the hexagonal plates of the shell, and the socket sunken into the base of the spine, and the spine movable in any direction at the will of the animal.

Among these spines, of which a full-grown sea urchin carries more than twelve hundred, there are a number of tiny, curiously formed pincers, each of which has three prongs. With these, as with little hands, the sea urchin lays hold of seaweeds to steady himself in climbing, or in picking out whatever may 
become entangled among the spines, and passing it down the sides of the body until it can be dropped into the water.

The shell of the animal, like a terrestrial globe, is marked with meridians, ten of them extending from pole to pole, or from the top to the bottom of the sea urchin. Each of these meridians consists of double rows of plates, which fit one another closely and firmly. Five of these meridians are called "s.mbulacral areas," or walking parts, for through holes in the plates extend tubes with suckers at the ends that serve the animal as limbs and feet. Between each two of these walking parts is another and wider meridional space which is called "inter-ambulacral," or between walking parts, which bears spines instead of tube limbs.

As a sea urchin has legs all around his body, it really does not matter whether he walks upright, on his side, or upside down, or turns himself, as he sometimes does, like a ball rolling slowly along, over and over as he advances.

The mouth, situated at the bottom of this strange animal, has no less than five jaws, each provided with a long, projecting, movable tooth. A complicated muscular system works the jaws up and down and across each other, so that a better mill for grinding up the sea urchin's food could not be invented. Nor is this all or the strangest part of it, for these same jaws are able to hollow out homes for the animals in solid rock, in sandstone, and the hardest granite. That they do it no one can doubt; how they do it no one 
can tell, for their teeth are not superior in hardness to those of other animals; certainly not nearly as hard as the rocks into which they burrow. The kole which the sea urchin forms in stone is large enough to allow lim to move about, but not to come out very easily; indeerl, he adheres so firmly with his suckers to the cavity as not to be easily forced to quit his hold.

\section{A NEST IN A WATERFALL.}

AMERICAN DIPPERS.

These little birds, which are in reality thrushes, combine, says Dr. Cooper, "the form of a sandpiper, the song of a canary, and the aquatic habits of the duck."

Although its feet are not webled, the dipper is in some respects more of a water bird than is a duck, for in search of its food, which consists almost altogether of water insects, it descends to a depth of several feet, walking about on the bottom and flying beneath as easily as it does above the surface of the mountain streams it frequents.

The dense, thick plumage of the dipper, unlike that of any other land bird, is furnished with an undergrowth of downy feathers. While under the water the coat of the dipper, through which no dampness can penetrate, shines like silver, on account of the air bubbles adhering to it. 


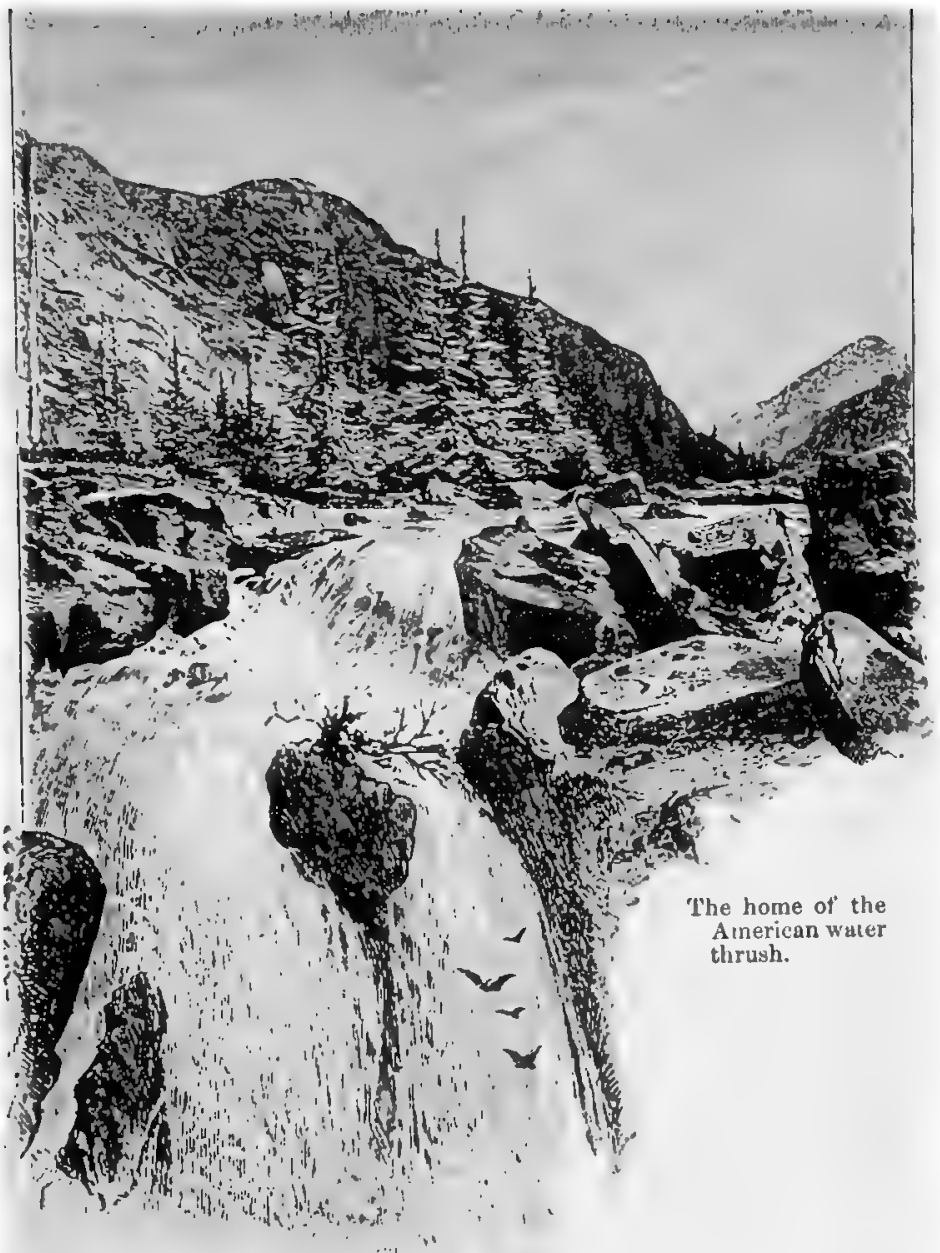


In places where the birds are sufficiently numerous they will take possession of a mountain stream from its source to its mouth, each family occupying about a quarter of a mile of its length, and never intruding on the domain of its neighbors.

They are very quick and queer in their movements, flying with a rapid buzzing of the wings, and following closely every turn and elevation or depression in the level of the stream, until they drop suddenly and disappear beneath its surface.

"When there is sufficient depth for a plunge," says Prof. Nuttal, "they open their wings and drop them with an agitated motion, and with the head stretched out as in the ordinary act of flying in the air, descend to the bottom, and there, as if on dry land, course up and down in quest of food."

Mr. Mudie observes, in regard to this: "A question has been raised how the dipper can keep beneath a fluid so much more dense than itself. An owl to an owl's bulk of air is as eight pounds to one as cornpared with the dipper's bulk of water to the dipper; but if birds ascend into the air at pleasure by the motion of their wings, it is only reversing those motions to enable them to descend or keep themselves down in the water. The difference in specific gravity between the bird and the water is indeed so trifling that very little effort is needed to move it in any direction downward or sideways.

"Birds do not fly because they weigh little, for with equal wings the heavier birds fly best; they do so because they strike the air more forcibly in the op- 
posite directions and send themselves forward in the way they wish to go, their greater weight enabling them to make better headway through the opposing air.

"The dipper does just the same. If it wishes to go downward, it strikes upward with its wings; to come

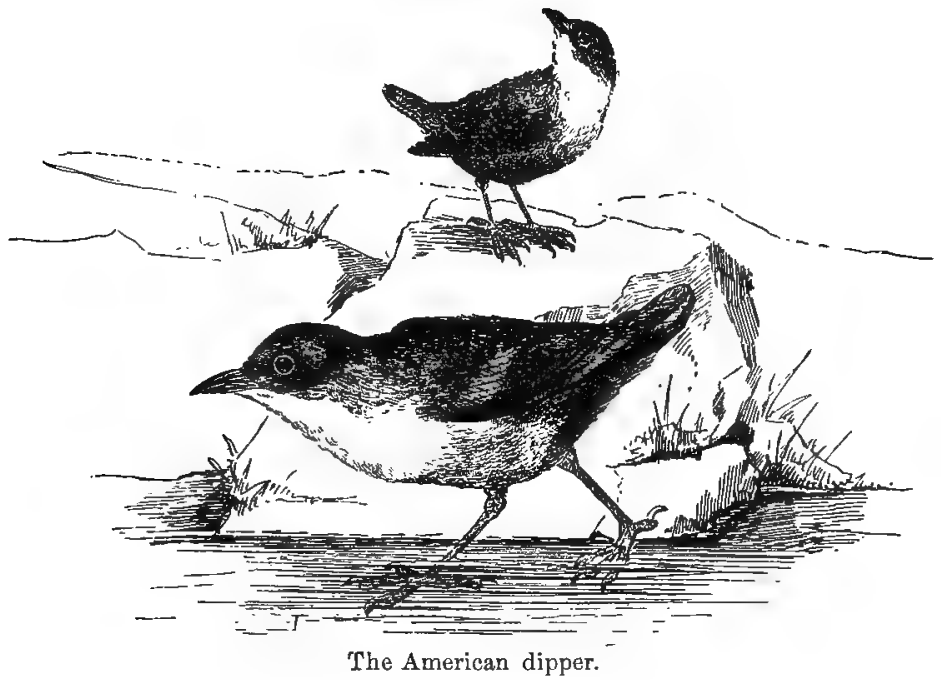

up, it does the reverse. The only difference is that the wings are held recurved, as running birds use them, and gravitation has even less to do with the matter than in flying."

The nest of the dipper is placed as near the water as possible. Dr. Cooper found one built under the roots of an enormous tree that had floated over and rested in a slanting position against the dam of a saw- 


\section{$21+$ CURIOUS HOMES AND THEIR TENANTS.}

mill on the Chehalis River. The floor was of small twigs, the sides and roof, arched over it like an oren and formed of moss, projecting so as to protect and shelter the opening, which was large enough to admit the hand. Within this nest was a brood of halffledged young. The parents were familiar and fearless, and accustomed to the society of the millers.

Another nest described by the naturalist was built at the foot of a milldam, resting on a slight ledge under an overhanging rock, from which water was continually falling. It was shaped like an oven with a small doorway, and was built of moss green and growing, so that it was no easy matter to discover the nest. It was lined with soft grass and contained young.

A number of nests have been found built upon rocks behind cascades, where they were kept continually wet by spray from the falling water, showing this to be a farorite locality for the birds in building their homes. In leaving and returning to their young it was necessary to dash through a sheet of falling water. The dipper is the only aquatic song bird, and its song is very sweet and musical. 


\section{PORTABLE HOUSES.}

CAMELS CARRY THE VILLAGES FROM PLACE TO PLACE.

The Turcomans, who live on the eastern shores of the Caspian Sea, carry their villages about with them as they travel. When a tribe sets out on a journey, every man packs his wooden house upon a camel, which the animal can easily carry; and after a spot is reached where he and his friends intend to remain any great length of time, the camels are unloaded and a village started, which it takes about an hour or so to build.

It is to be remembered that the houses are real houses, and not tents, and that the settlement is not a camp, but a village.

The traveling house of the Turcoman is a marvel of skill and ingenuity, and is really much lighter, more portable, and can be packed into a much smaller compass than any of the so-called portable houses that are manufactured and sold in some parts of our country.

The frame is made of strong, light wood laths about an inch broad by three quarters of an inch thick, crossing each other, when set up in position, at right angles, about a foot apart, and fastened at each crossing by thongs of rawhide, so as to be movable, and the whole framework may be opened or shut in the same manner as those toys for children that con- 
sist of a squad of wooden soldiers and will expand or close at will so as to form open or close columns.

One frame or more marle in this way, inclosing a circle fifteen or twenty feet across, forms the skele-

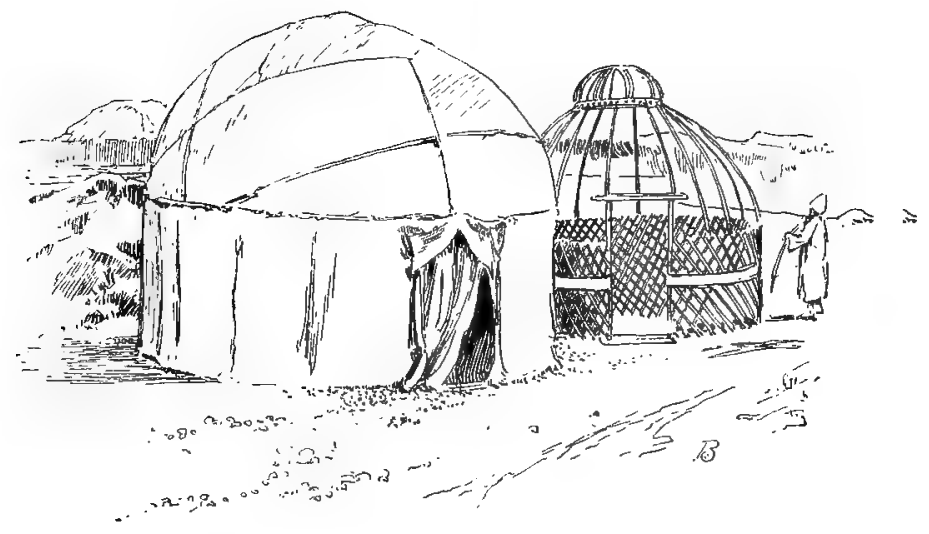

Turcoman's portable dwelling.

ton of the walls, which are firmly secured in places by bands or ropes made of hair or wool, fastened around the end of each rod.

From the upper end of these rods, similar rods, bent near the wall end into something less than a right angle, are so disposed that the longer proportions slope to the center, and, being tied with ropes, form the roof. Over this is thrown a covering of black felt, having in the center a large hole which answers both for a window and a chimney.

Large pieces of the same coarse black felt are wrapped around the walls; and outside these, to keep 
all tight, is bound another frame of split reeds or canes, bound closely together with strong cords, the pieces being straight up and down. This is itself secured by a broad band of woven hair stuff passed around the whole structure and united at the ends.

The large opening at the top can be closed, if needful, with a piece of felt, which is drawn on or off by a strong cord, like a curtain. 'If there is danger from the wind, a stick is placed on the side opposite from which it blows, which supports the fabric.

Sometimes the house is divided into two apartments by means of a screen of split reeds; but if more rooms are needed, separate houses are generally put up.

Upon the black tops of these houses may be seen large white masses of sour curd pressed out of buttermilk and put there to dry, to be set aside for future use. This, broken up and mixed with water, forms a very refreshing drink.

Carpets of felt are spread inside the house. These are sometimes made in the shape of a horseshoe, with a hole cut in the center for a fireplace, and the two ends cut off, so that those who do not wish to take off their boots may have a place to sit without soiling the carpet with their muddy soles.

There is no furniture except the trappings of the camels, the saddles and bridles of the horses, and the bags in which things are packed; but swords, guns, bows, spears, and arrows, with odds and ends of all kinds, may be seen hung on the ends of the wooden 
rods, which form very convenient pins for the purpose.

The folks who live in these portable villages are strange people. If they should catch you in one of their robbing expeditions-for they are a nation of robbers-they would take aray everything, even your freedom, and treat you with the utmost cruelty; but if you should come to them as a visitor, even though a perfect stranger, they would entertain you as a brother, feed you, perhaps clothe you, give you a horse to ride, and provide as far as they could for the rest of your journey.

Their villages are generally square, inclosing an empty space or forming a broad street, the houses being placed on either side, with their loors toward each other.

But although these portable louses of the Turcomans are so skillfully contrived, they can scarcely be said to be as light and handy for their occupants as the shells used by the hermit crab, who, instead of having to employ other animals, as the Turcoman uses camels, to carry his house, seems to find little trouble in taking it with him, wherever he goes, on his own back. 
PORTABLE HOUSE OF THE HERMIT CRAB. 219

\section{THE PORTABLE HOUSE OF THE HERMIT CRABS,}

AND WHAT ARE CARRIED ON THE ROOFS.

The hermit crab is by no means a solitary individual, since many are often found together. $\mathrm{He}$ can scarcely lay claim to so respectable a name, and might much more appropriately have been called the robber burglar, or even the assassin crab, since he often gets possession of the portable dwelling in which he lives by killing and eating its rightful inmate and possessor. But the law that governs the lives of lower animals, whatever may be that obeyed by man, is a very simple one-to eat, and not be eaten; and all their wonderful instincts, aside from those connected with their young, are directed to this end.

Having eaten, and made his dinner serve the double purpose of satisfying hunger and obtaining for him a protection against being eaten, the hermit crab proceeds to back into his new dwelling and fill it up with his soft unprotected hinder parts, while he allows his strongly armored limbs and formidable claws to project in front.

As he walks about he drags his house after him and bids defiance to his enemies, for he is a great fighter and always ready for single combat with his kind.

While still young and of small size hermit crabs 
live in shallow water on the coast, but as they grow older they retreat to the deeper waters, whence fishermen bring them up in vast quantities in their drag nets.

Having once obtained lodgings, a hernit crab remains in them as long as possible, for he does not like moving; and when he is forced to change his shell he takes care to select one too large for present use, so that he will have room to grow for some time without being obliged to quit lis quarters.

The soft stomach with which hermit crabs are provided, and which perfectly fits and lodges in his borrowed shell, is often couked and eaten together with his claws in Europe, where, by sailors at least, they seem to be considered a great luxury; but tastes differ, and I doubt if many people in the United States would relish such food.

Sometimes the drag net brings in great specimens of a shell called Buccinida, inhabited by a hermit crab of a particular kind, and fastened upon it a beautiful sea anemone. The strangest part of all this is, that this particular kind of shell seems to be monopolized by one species of hermit crab, and the anemone is never found on any other shell or upon one of those that contains the animal to which it properly belongs, being invariably fastened to a Buccinida inhabited by a hermit crab.

How is it that these two creatures so different in organization always associate together? The anemone has no eyes and no limbs, and can creep about only in a very lame and tardy fashion; the hermit crab supplies both. It is as if a blind and crippled soldier, 
PORTABLE HOUSE OF THE HERMIT CRAB. 221

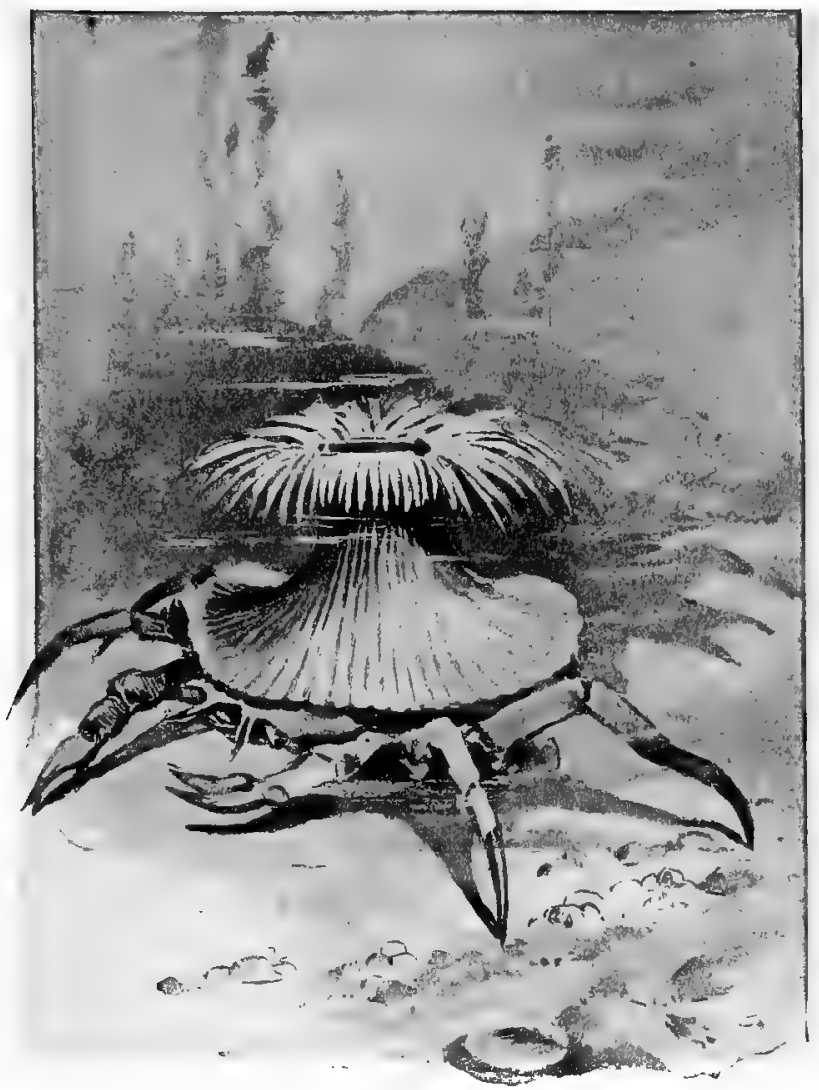

Hermit erab with sea anemon $\Theta$ on its back.

who nevertheless knew how to defend himself and his friend, were mounted on the back of a nimble-footed companion. 
The Adlunsia, which is the name by which the anemone is known, is nourishel by the food waste of the hermit crab, and it is even said that the latter carries his kindness so far as to use his claws to give food to his friend. The anemone is evidently a useful associate, preventing any approach of enemies with her numerous feelers or tentacles, which, indeed, have the power of stinging and paralyzing troublesome visitors.

A very significant fact proves the friendliness of the association. It has been already stated that as the hermit crab increases in size he is obliged to change the shell he inhabits for a larger one. But then arises the question, What is to become of the abandoned ancmone? When the hermit crab finds

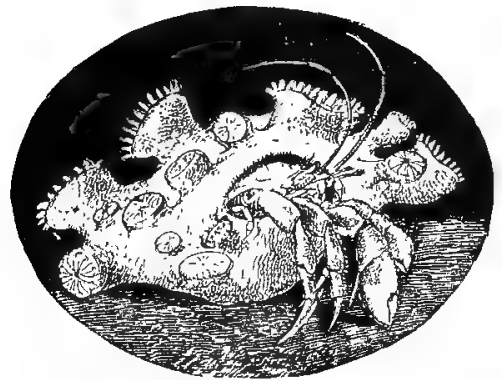

IIermit crab inclosed in a mass of polyps which entirely cover the shell in which it lives.

his quarters are too ('lose for comfortable habitation, and sets out and finds another and a larger shell, he makes this fact knownhow, no one but hermit crabs and anemones know, and they have nerer revealed the secret-to lis companion, who hastens to creep up and slip softly on the back of its friend's shell. Then the hermit enters its new dwellings and the old association is re-established. 
If, as sometimes happens, the anemone becomes detached from the shell inhabited by the hermit crab, the latter takes it carefully and tenderly in its claws and replaces it.

\section{A WARU HOUSE,}

AND THE FOOD PREPARED IN IT.

Houses are really indispensable in proportion to the inclemency of climate. They are needed most, perhaps, as shelters against wet and cold weather. Of course, they have many other uses to us; but it may be imagined that even a person accustomed to civilized life could more easily do without one where

"The skies never weep and the leaves never die,"

than here in our own land, to say nothing of those parts of the world where the climate is more severe.

The native Indian of Guiana has no conception of home in our sense of the word. It would be impossible to give him or any other savage an idea of the meaning the word has to us. It is one of the most complex of words, and belongs alone to our race and civilization.

In the same way the word houseless, which describes as forlorn and pitiable the condition of

"The houseless wretch for whom no hearthstone glows,"

means little or nothing to people whose houses are mere temporary cabins put up with at most but a few 
hours' work, and abandoned as carelessly as a sportsman in our forest abandons the shack he has built to camp in while hunting in the vicinity.

To the Guiana Indian a house is a place to hang up his hammock, and those of his wife and children, and often of his friends and their wives and children. 1 popular writer, in describing one of these habitations, says :

"Their architecture differs considerably, according to the district. As a rule, the climate is so warm that houses are but little needed, all that is required being a simple roof overhead. The ordinary kind of habitation is nothing more than a mere shed or sort of baru, without the walls, supported on posts and thatched with leaves.

"From the posts and rafters are hung the personal goods of the natives, such as pans, paddles, clubs, guns, bows and arrows, and similar articles, while from one or two of the crossbeams is sure to be lranging the singular cassava press. Between the uprisht postis, and sometimes from the transverse beams, are suspended the hammocks, some of which are almost invariably occupied, as the master has a natural genius for lying in his hammock when not absolutely obliged to be upon his feet. The number of hammocks under a single roof is almost incredible. They are liung in tiers, one above the other, like the berths on board a passenger ship, and when thirty or forty of them are occupied at once it seems rather wonderful that the building should be able to stand such a strain. 
"As the inhabitants move about or get into and out of their hammocks when replenishing the nightly fires, whose smoke is the only defense against mosquitoes

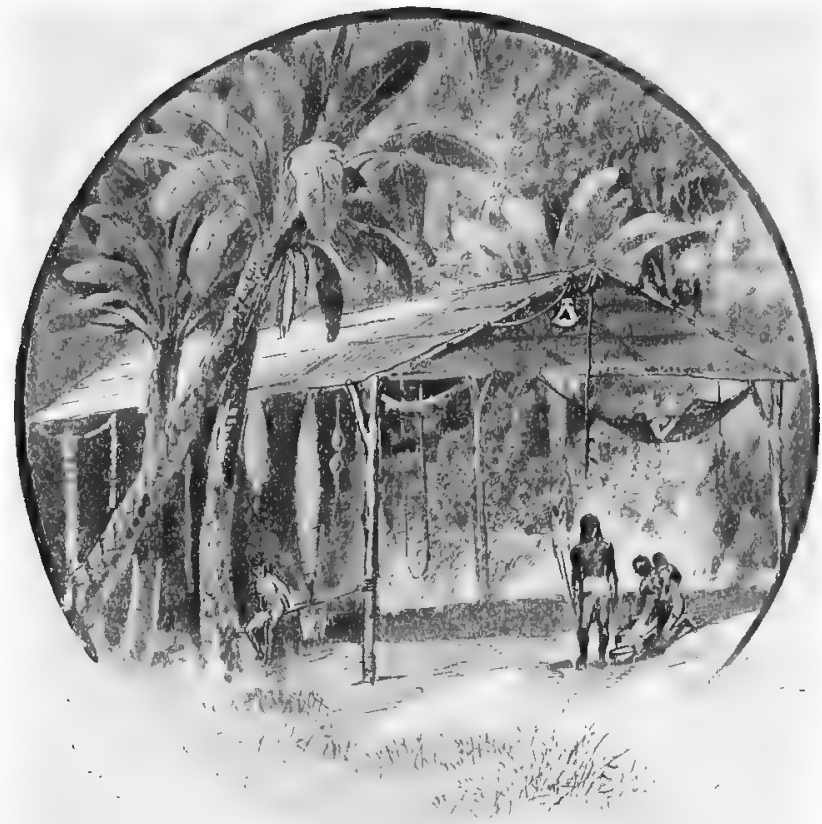

A waru house.

and other winged pests, the whole building rocks, the joints creak, and the house seems on the point of coming down. But the junctions of the beams and posts and rafters are so firmly tied that they are far stronger than they look, and, however fragile the shed 
may seem, it is quite equal to any strain it may bave to endure."

The Rev. Mr. N. H. Brett, who has given an excellent account of the Indian tribes of Guiana, says that, rude and simple as these houses seem to be, the place where one is built is not chosen without considerable care and judginent. In the first place, it must be within easy walking distance of a creek or river, not only that the women may with the less labor be able to supply water needed for household purposes, but that the canoes belonging to the owners of the house may be within easy reach for hunting excursions, or for one of the migrations which so frequently occur and is liable to happen at any time among these people.

It must be in a retired and sheltered spot, where the household will not be likely to be invaded by unwelcome visitors, travelers, and the like, or any sort of strangers; for the Indian, rude as he is, values domestic privacy, and does not like surprise parties; and, as a last requisite, it must be upon soil light and sandy and easy to cultivate.

The forests inhabited by these people abound in game, and their waters with fish, so that they have the less need to cultivate their lands. In fact, their principal vegetable food is cassiavi, which is much the same as tapioca.

The principal source of supply is a plant called Jotrophiu munthet, the juice of which is so deadly that a very small dose will kill a person. This is true, however, only when the plant is fresh. Dried, 
pressed, and baked, it is as wholesome as any ; though, perhaps, if some of our careful sisters and aunts and mothers knew that fresh tapioca is a deadly poison, they would be a little timid about using it.

The tapioca is prepared by shredding the rootsthe part of the plant used-into thin shavings. This is done by means of a board into which is fastened in regular rows a number of pieces of sharp stone or, of late years, iron nails, over which the roots are dragged.

The next process in order is to get rid of its poisonous juices in various ways, by subjecting it to pressure of some kind, but lastly and most effectually by putting it into what is called the tipita or native press.

The tipita is an elongated cylindrical basket. This basket, woven of the bark of a particular kind of palm tree, is very elastic in the middle, and quite stiff and unelastic at the ends. It is first stuffed as tightly as possible with the shredded cassava, which naturally has the effect of making it very much shorter and very much thicker in the middle. Beneath the tipita is placed a bowl of coarse earthenware, such as these Indians make, to catch the juice. A great stone, or something as heavy as possible, fastened to the lower end, elongates and narrows it and forces out the juice that yet remains in the cassava. A pole is then fastened in a strong loop at the lower end of the tipita, and the shorter end secured to one of the posts supporting the roof; upon the longer end of the pole is then hung the weight, which is further increased by an Indian, or, it may be, as many as can conven- 
iently do so, perching upon this end and bringing a proportionally powerful leverage to bear upon the tipita.

There is, however, something that yet remains to be explained concerning this process. Why should

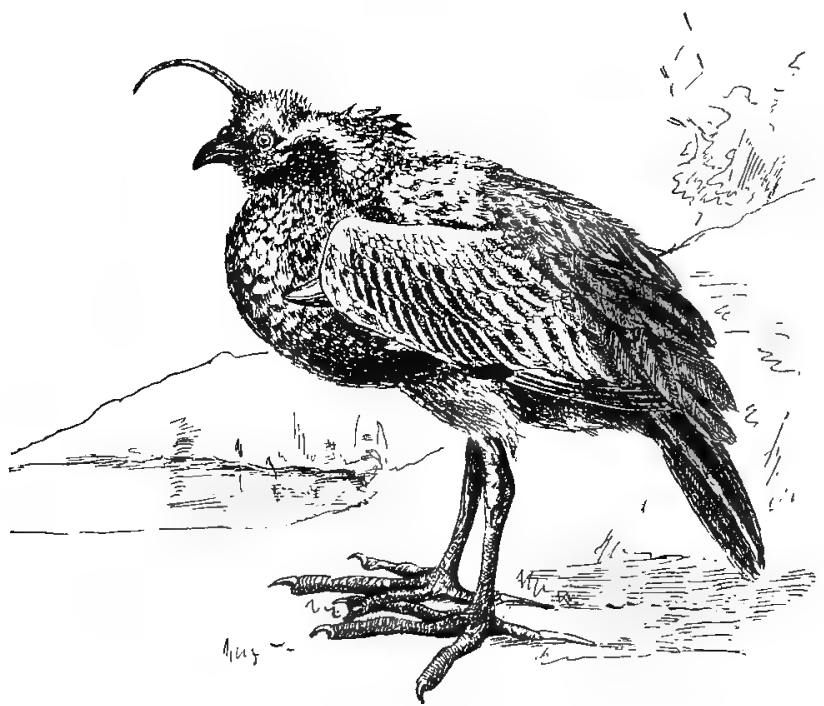

The anhinia.

the juice thit drips from the tipita be collected and preserved? The cassava is freed from it, because it is poisonous. If any one drank of it he would die in great agony-that is, if he drank of it before it was boiled. Before it is boiled it is a deadly poison; after it is boiled it is wholesome sauce, and to the taste of the natives a delicious one. There would 
be, however, for either the reader or writer of this account of it a fatal objection to its use. It is the chief ingredient in what is called pepper pot throughout the West Indies, and as used by the Guiana Indians is so highly seasoned with red pepper that when the white traveler, pressed by his hospitable Indian host, who has served him with cassava bread and cassareep sauce, tastes it, the tears start to his eyes. He does not care for anotier mouthful-he knows when he has had enough!

The more stationary and settled Indians in Guiana and Venezuela keep great numbers of domestic fowls, which, strange to say, in the absence of any inclosure are kept from straying by a rather large bird called the anhimia. This faithful creature takes the most excellent care of them, leading them ont in the morning and bringing them back safely at night. The anhimia wili fight for her charges, and can successfully resist the attack of any hawk, or the smaller wild cats that abound in the forests.

\section{A HOUSE THAT WEARS A HAT.}

HOW IT IS BUILT.

A dwelling the construction of which, consisting as it does of galleries surrounding a central chamber, that suggests, although built aboveground, the habitation of the mole, is that of a remarkable people of 
southern Africa visited by Dr. Anderson-the Makalolo tribe.

The women are the house-builders. It is all the hard work they do, but they doubtless think it enough.

The house is begun by planting a circle of stakes in the earth so that they will project nine or ten feet aboveground; reeds and weeds are next woven in and out of the stakes, and a cylindrical wall is formed by plastering the whole with mud made from anthills, which, as you probably know, are of immense size in Africa. This sort of material makes a very smooth, firm, and even surface. The floor is plastered as well as the walls; this is a great improvement on the floor of earth in most native huts, as it can be kept clean and does not harbor insects.

The central circular chamber being finished, a large conical roof, shaped like the hats worn by Japanese and Chinese coolies or workmen, is constructed. This is, in fact, the hat the house is to wear. All the workwomen place themselves about it where it is made, lift it from the ground, and carefully set it upon the circular tower they have built.

As the rim of the great hat projects considerably beyond the plastered cylinder, it is supported by pillars consisting of stakes driven into the ground, which are made into a partition reaching almost to their summits by means of interlacing reeds and plaster made of earth obtained from ant-hills. Another wall built upon stakes that meet and support the extreme ends of the rafters, but only about half as 
high as the interior one, completes this strange edifice, consisting of three rooms, the two outer ones in the form of circular galleries, and the inmost a cylindrical-shaped chamber.

The thatched roof, or hat, is not permanently fixed to the walls upon which it rests. It can be lifted off in pleasant weather, opening up the inside cham-

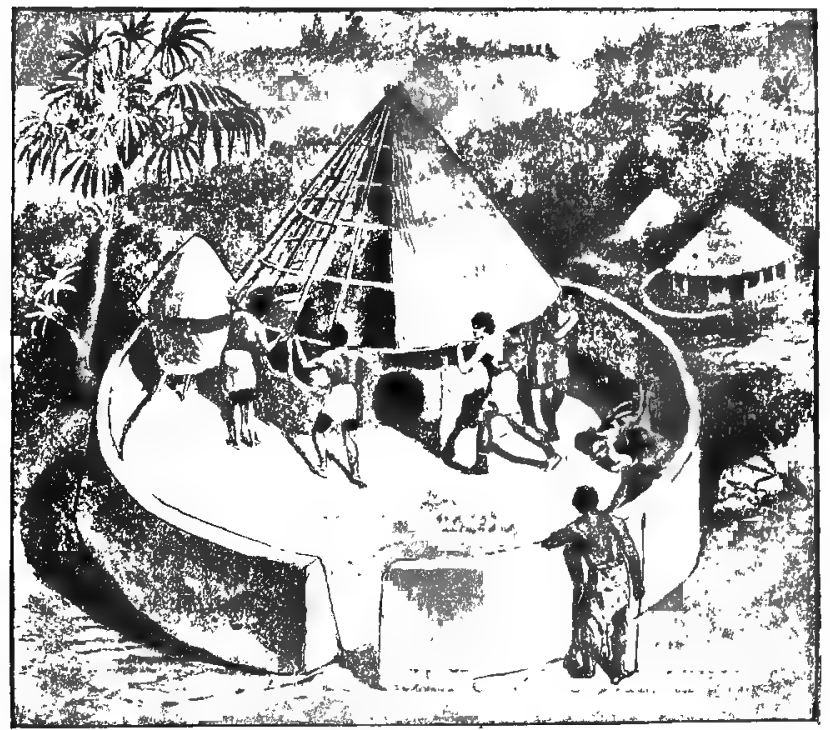

Building the house that wears a hat.

ber to the fresh air, which is the more desirable as there is absolutely no other means of ventilation provided, except an absurdly small door a little more than a foot and a half high, and very little wider. A 


\section{CURIOUS HOMES AND THEIR TENANTS.}

well-grown white child might find some difficulty in creeping into some of the smaller doorways, not to speak of an adult; but a native Makalolo seems to make his way through easily enough, though low he manages to exist in the close atmosphere inside is a difficult question to answer.

When there is any lack of accommodation for visitors-as there always is, for every house is fully occupied-the Makalolos doff their roof instead of their hats, and taking it from the walls place it upon the ground at the disposal of their guests, who, though its accommodations are decidedly limited, make shift to creep under it and shelter themselves there, while the inmates of the house remain roofless unless they happen to have an extra roof or so for such occasions.

Although the Makalolo women are the only housebuilders in the tribe, they have so much unoccupied time on their hands that they are apt to fall into idle habits; for, contrary to the habits of savages generally, the men do all other hard work.

\section{DWELLINGS IN SKELETONS OF WHALES,} AND HOUSES OF SAND.

Perhaps the strangest dwellings ever occupied by human beings were those found on the shores of Encounter Bay, in Australia. Whether any yet survive the march of civilization may be questioned, for 
the aboriginal people who inhabited them are disappearing like snow in midsummer. Not many years ago, however, they were sufficiently numerous to attract the attention of travelers in that wonderful country.

The Australians, who are without any doubt the most primitive of people, are also the most omnivorous. They, like our Digger Indians, will eat anything that can be chewed and swallowed, and some things that can not, as, for instance, the roots of bulrushes, which are of so fibrous a nature that it would be as easy to swallow a skein of yarn; and certain shellfish which, though they may perhaps be swallowed, are no more to be chewed than so much sole leather.

The native Australian relishes fried tadpoles and roasted caterpillars, and fairly luxuriates on fricasseed snakes and lizards. The greatest possible treat, however, is whale's flesh. A dead one is now and then washed ashore, and as its "ancient and fishlike smell" penetrates throughout the country for miles around, the natives follow their noses down to the shore where it is stranded and gather about it with great rejoicing.

Enormous as is the supply, the demand is so great that in a comparatively short time nothing but the skeleton remains. This forms the framework of a house, the ribs and backbone constituting the arched roof, which is covered with leaves, grass, and matting to render it impervious to wind and rain. Like mice in a cheese, the Australians eat out the inside and then make their home in the shell of their food supply.

On another part of the Australian coast the dwell- 
ings of the aborigines are formed of a framework of sticks, over which is plastered a thick layer of turf and mud; this is covered with sand, so that a village of Milmenduras, as these people are called, would never be taken for anything else than a collection of , sand heaps overgrown, perhaps, with the abundant creeping plant, the monterry, which bears a small fruit resembling in form and taste a miniature apple.

\section{A HOME IN A HORN,}

AND THE ANIMAL THAT LIVES IN IT.

A mammal that makes its home in the horn of a sheep is certainly a novelty. But such a dwelling place is no novelty to the animal, for from time immemorial he and his ancestors have had no other.

Giants among their kind, the mountain sheep not only surpass all others in stature, but their horns, in proportion to the animal that carries them, are far the largest borne. Among these huge sheep the argali of Siberia is pre-eminent, being almost equal in bulk and weight to an average-sized $o x$, and the horns he bears are proportionally enormous.

Much resembling those of our own Rocky Mountain sheep, the horns of the arguli are yet larger. Springing upward from the forehead, they curve backward and with a bold sweep descend below the muzzle, then, recurving upward, taper off to a point. 
They are hollow and, though stout and elastic, and buttressed and strengthened wonderfully by a series of ridges or horny rings set close together, are often badly bruised, battered, and broken in the fierce combats waged by rival rams fighting for the leadership of the flock. This has given rise to a story told of the ibex, and the Rocky Mountain sheep as well, that the animals use their horns as buffers. "A ram," we are told, "leaping from a great height, alights upon them, and their strength and elasticity, breaking his fall, saves him from a shock that would otherwise prove fatal." If this were really the case, it would be a pity that the female sheep, whose horns are comparatively light and small, are deprived of so useful a safeguard.

The fact is, however, that no living mammal, especially no mountain sheep, whose necks are not especially large or strong in proportion to the size and weight of their bodies, could survive such a manner of alighting.

Though the horns of the argali are larger than those of his American cousin, it would seem that they are not as strong, for, firmly set as they appear to be upon his forehead, they are sometimes broken completely off.

When the native hunters kill one of these animals they either use the horns-which are capacious enough to contain several gallons of liquid-as vessels in which to carry a supply of water, or convert them into various articles of domestic economy. Nor are those broken off in the shock of battle allowed to lie un- 


\section{CURIOUS HOMES AND THEIR TENANTS.}

noticed upon the ground where they have fallen, but are soon utilized by the Siberian fox, who not only stows itself away in it as snugly as a hermit crab in a sea shell, but employs it as a dwelling place in which to nurse and rear its little family in comfort and safety.

\section{A CITY OF BIRDS.}

THE PENGUINS.

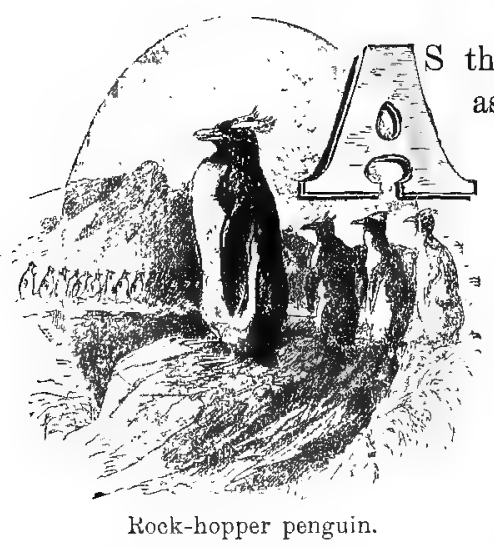

there are mammals, such as seals and walruses, that can not walk, so there are many kinds of birds -some, strange to say, with large and welldeveloped wings-that can not fly. The penguin, properly speaking, has neither legs nor wings; what answer for the latter are paddleshaped limbs something like the flippers of seals; and the legs of the bird are so illy adapted for walking, that while some species can shuffle along much like a person whose feet are inclosed in a narrow sack, others can not walk at all, and get about on shore by jerking themselves forward with a hitch and a short jump. 
But, though as helpless on land as the seals, to whose manner of life theirs bears in many respects so great a resemblance, they are, like the latter, perfectly at home in the water, which they never leave except to lay their eggs and rear their young. Indeed, it may be said that they belong to the ocean almost as much as do certain fish that occasionally land and creep about the beach; for they not only swim upon the

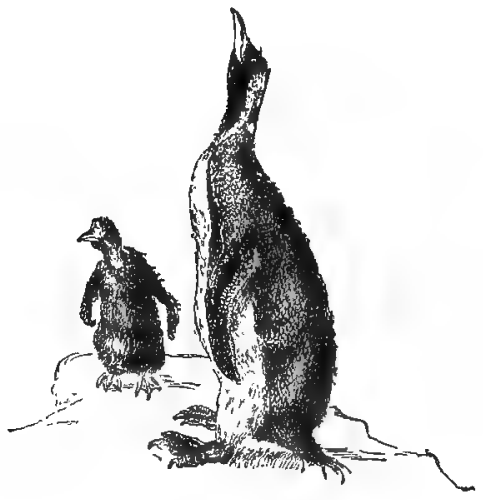

Old penguin and nestling. surface, but, like dolphins and porpoises, sound the depths of the sea in search of the crabs and marine animals upon which they feed, and fly about under water as other birds do in the air.

Wonderful stories are told of the breeding places and habitations of these strange, fishlike birds. This is told us by Mr. Louis Figuier: "At certain periods of the year the penguins assemble on the beach as if they had appointed a particular day for the purpose. These assemblies last for a day or two, and are conducted with evident solemnity. When the meeting results in a decision they proceed to work with great activity.

"Upon a ledge of rock sufficiently level and of the. 
necessary size they trace a square, with one of its sides parallel and overlooking the edge of the water, which is left open for the going out and coming in of the colony; then with their beaks they proceed to collect all the stones in the neighborhood, which they heap up outside the lines marked out, to serve them as a wall to shelter them from the prevailing winds. During the night these openings are guarded by sentinels.

"They afterward divide the inclosure into smaller squares, each large enough to receive a certain number of nests, with a passage between each square. No architect could arrange the plan in a more regular manner."

Penguin city is laid out with streets and lanes, along which groups of citizens may constantly be seen going to or coming from the water.

Dr. Bennett, in speaking of one of these cities, says it occupied from thirty to forty acres of ground; and so numerous were its inhabitants, that during the whole day and night from thirty to forty thousand of them are continually going to sea, and as many landing.

"They are," he says, "when on shore, arranged in regular ranks, in as compact a manner as a regiment - of soldiers, and are classed with the greatest order, the young birds in one place, the molting birds in another, the sitting hens in a third, and the clean birds, in perfect feather, in a fourth; and so strictly is this order kept, that where a bird endeavors to intrude itself in a class to which it does not belong, the 
trespasser is immediately driven out from the precincts he has invaded."

Another species-the gentle penguins, commonly called Johnnies-build hamlets and villages of from a

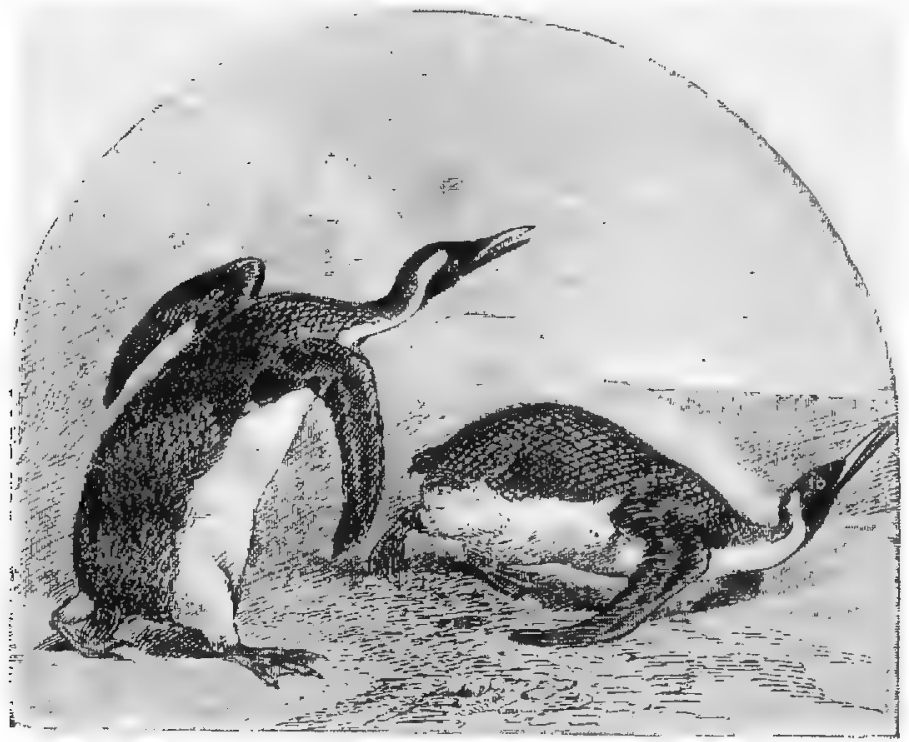

Penguins running.

dozen to seventy and one hundred and fifty families or more. Rev. A. E. Eaton has written a description of a small community of these birds at Royal Sound, Kerguelen Island, which, as you may know, is situated very far south, in the Indian Ocean. He says:

"The birds occupied a position on the neck of a low promontory within an hour's walk of Observa- 
tory Bay. Their nests were nearest the farther sicle of the isthmus, but when they were approached the male birds would run to the water, not by the shortest route where it was deep, close to the rocks, but by the longest, to a place where the shore was shelving.

"It was amusing to see a troop of them start off as fast as their abbreviated apologies for legs would allow them, holding out their ridiculous-looking wings like the sleeves of coats so long as to conceal the wearer's hands, and tumbling headlong over stones and other obstacles in their way, simply because, instead of looking to see where they were going, they would persist in gazing backward at their pursuers, and shouting and scolding at the top of their roices. Panic seemed to possess them all, but the females, allowing their mother-love to overcome their fear, soon returned to their nests, and, if the intruder stood still, soon settled down again upon their eggs.

"Not many weeks passed before a change took place in their behavior. The young were hatched, and now the mothers anxiously endeavored to persuade them to follow the example of their fathers and run away to sea. But the nestlings much preferred to stay in their nests; they did not care if the stranger did stroke them, although their mothers would run at him with open beaks if he dared to do so. Only a few of the older chicks could be prevailed upon to stir, and they, after waddling a few yards, became satisfied with their performance and turned to go home again. Their mothers, who had straggled to a greater distance, began also to return. 
"The tardy youngsters now began to experience the ills of life. Every penguin that had reached its place aimed blows at them as they passed on the way to their own abodes.

"One of these little birds certainly did seem to need correction. It saw its neighbor's nest empty and sat down in it. The old female Johnny, the rightful occupier, presently returned in company with her own chick, to whom, after having put her head well into his mouth, she began to administer refreshment after his run. Seeing them so pleasantly engaged, the small vagrant, thoughtlessly presuming on her generosity, presented himself to be fed, as if he also had a right to her care and attention.

"She looked at him as he stood gaping before her with drooping wings, unable for a moment to credit what she saw. But suddenly the truth flashed upon her, and, provoked by his consummate audacity, she gave vent to her indignation, pecked his tongue as hard as she could, chased him out of the nest, darting blows on his back and croaking ominously as he fled precipitately beyond the reach of her beak, leaving trophies in the form of shreds of his downy coat upon the scene of his unfortunate adventure." 


\section{FEATHERED GARDENERS,}

AND THEIR BEALTIFUL ('ABINS.

Birds build houses and lay out gardens and playgrounds.

Fancy encountering in an unexplored land, in the recesses of a primeval forest, far away from human habitation, a tiny cabin set in miniature pleasure grounds studded with brilliant flowers.

That such a piece of workmanship, more lovely than the ingenuity of any mere animal has ever before been known to construct, is in reality built with beaks or claws, is probably an idea less likely to enter the mind of the discorerer than that fairies, after all, do exist, and, flying from civilized lands, have found refuge here, and that the little house and mossy meadow is one of their places of abode.

The architect, however, is in reality a bird which, though allied to the magnificent bircls of paradise, that also inhabit the great island of New Guinea, is neither remarkable for color or size, being of a plain uniform reddish brown, and about the size of our common American robin.

As descriled by its discoverer, the garden birdfor so he called it-when it sets out to build one of its remarkable structures first selects a woody plant with a stem about the height and girth of the handle of a lady's parasol. This plant must be surrounded by 
a flat piece of land on a level with the ground about it. Around the trunk of the shrub which it has selected the garden bird proceeds to break ground. The first thing to be done is to carefully clean and level the space chosen. As this would be too much for one bird alone to undertake, it probably receives aid from a number of its companions. An ordinary bird's nest is generally built from suitable material easily found in its immediate vicinity, but that of which the garden bird constructs his summer house must be sought for far and wide. The style of edifice erected on the carefully prepared foundation, although in every case elaborate and beautiful almost beyond belief, depends upon the particular species of the genus that builds it. In Australia, where the birds are called bower birds, the structure built is an arched tunnel of twigs, skillfully and firmly built and interlaced, and decorated with all sorts of pretty shells and feathers.

Speaking of these playhouses of the birds, a recent writer justly says, "Perhaps the whole range of ornithology does not produce a more singular phenomenon than the fact of a bird building a house merely as a place of amusement, and decorating it as if to mark its design and purpose."

Without doubt, however, the garden bird of New Guinea surpasses all other birds in constructive ability. Around the trunk of the selected shrub in the center of the prepared space, which it uses as a center pole, the little feathered workman proceeds to build up, from the prettiest mosses it can 


\section{CURIOLS IIOHES AND THEIR TENANTS.}

find, a cone about as large across its lase as a dinner plate. This is not done alone to beautify the cabin, but to strengthen its central support, which is to sustain the entire weight of the construction. It selects for its rafters the long, straight, slender stems of a kind of orchid (Dendrobium) that grows in large dense tufts on the mossy boughs of trees, sending out upright branches about twenty inches in length. One reason the wise birds have tor selecting these stems is that the plant to which they belong is an "priphite, or air plant, and requires only air and moisture to live and grow. The small and pretty leaves, so closely packed together, will continue alive and fresh after the stems upon which they have grown are built into the walls of the cabin, that would otherwise soon become unsightly and fall into decay.

All about the top of the center pole and slanting outward from it, regularly laid with their upper ends resting upon the central support and their lower ones on the ground, are the long stems placed, all around, except immediately in frunt, where an opening is left for a doorway, so that when finished the cabin is quite regular in form and conical in shape. Many other stems are also used, and so compactly interwoven that the whole structure is strong, and impervious to the rain. Around the central cone of moss runs a horseshoe-shaped apartment or gallery. The cabin is about twenty inches high, and twice that in diameter.

"But," salys their discoverer, "the æsthetic tastes of our gardeners are not restricted to the construc- 
tion of a cabin." Their fondness for flowers and gardens is still more remarkable. Directly in front of the door of their cabin is a level space occupying at least as much ground as the structure itself. This is a garden of fresh, green, growing moss, brought here by the birds, and with the utmost care kept smooth and clean, entirely free from dirt or litter of any kind, all stones, sticks, etc., falling from the trees above, or brought by the wind, being at once removed. The verdant and velvety surface exhibited by the miniature meadow does not, however, entirely satisfy its owners. Something is yet wanting, and they proceed to scatter over it the most brilliantly colored flowers and fruits they can gather about the forest--wings of butterflies, lightly painted shaies of beetles, and showy fungus growths. The greatcr number of these ornaments are deposited near the entrance of the cabin. The variety of objects thus exhibited is very great, and they are always of the most brilliant colors. As soon as any have been so long exposed as to lose their freshness they are taken from the garden, thrown away, and replaced by new ones.

It remains to be said that these little cabins are not used by the garden birds as nests. Their real homes are in the tops of the tallest forest trees; it is there they lay their eggs and rear their young. These dainty little summer houses and flower gardens are, if you please, their playhonses, where it is probable they invite their lady and gentleman friends for a frolic. 
246 CURIOUS HOMES ANI TIIEIR TENANTS.

Were this account not vouched for by sober, unimaginative scientific men, it might well be doubted, but a reference to recent ornithological reports will not only give fuller details of the matter, but tell of other more recently discovered varieties of the garden bird, that build structures of a different kind that are equally as surprising as those here described.

It is safe to say that nothing so strange and beautiful, among homes built without hands, will ever be found on this planet of ours as the summer houses and pleasure grounds of the garden birds of New Guinea. Nature has more than compensated for the deprivation of superb plumage such as that given the bird of paradise, by bestowing upon the garden birds the ability to make little paradises to gratify their inborn love of beauty, that seems inherent in the whole family.

\section{FUN-LOVING KAGUS,}

AND THEIR QUEER ACTIONS.

There is in the Zoölogical Gardens in London a bird whose aviary is constantly surrounded by groups of children shouting with laughter and vigorously applauding, as if they were witnessing the performance of some favorite play-actor, comedian, or pantomimist, instend of the antics of a rather commonplace-looking fowl, neither as remarkable for shape or plunage as many another about him. 
If, however, you were to join one of these groups of spectators and watch his antics, I feel sure you would acknowledge him to be as funny as any human being or monkey you ever saw.

He has such an old-fashioned, high-shouldered, learned look when you first see him that you can not help respecting him, much as if he were really and truly the wise old professor he looks to be-a German professor, perhaps, such as you have seen pictures of-a professor in a gray dressing gown, with his hands behind him, and his head and long red nose thrust forward, nodding at every step as he stalks solemnly about, rapt in silent meditation.

The dignity and seriousness of his gait and expression, indeed, are something that must be seen to be appreciated; as must also the suddenness with which all this-his stately, formal, and decorous deportment-disappears.

All at once his sleepy companions, dozing on their perches or meditatively dressing their feathers and pluming themselves, awake to the fact that they have a feathered terror among them, and that the hitherto unobtrusive kagu, whom they had found no particular occasion to notice before, has apparently gone mad. With wide-open beak and outspread wings, with a sudden development of an ominous and most preposterous crest where none was to be seen before, and a harsh, rattling noise, he rushes at the frightened inmates of the aviary; he drives them frantically squalling, shrieking, and flapping in every direction; he chases and upsets them, and is not satisfied until, 
master of the field, he alone remains on the ground, and every one of his companions is clinging in mortal terror to the topmost wires of the great cage.

His satisfaction at this achievement is evident; his enjoyment is unbounded. He runs, prances, and skips about in the most undignified fashion, and finally, taking the tip end of a wing or tail feather in the end of his beak, he indulges in a high-stepping, light, fantastic waltz that is absurd and preposterous beyond description. His performance generally winds up with picking up a stray feather-there are sure to be plenty lost in the hurly-burly he has been causing-tossing it up in the air, chasing, catching it and tossing it up in the air again, until he is tired or has worked off his flow of spirits. Occasionally, however, he varies this performance by sticking his bill deep in the ground, standing on his head, flapping his wings, and flourishing his long red legs wildly in the faces of the spectators, who never fail to greet the performance with shrieks of langhter.

Certainly such another amusing bird does not exist, unless it is a sort of second consin of the kagu, the shadow hird, or Scopus umbrella, of Africa, that plaps in pretty much the same way.

As the homes of these two birds probably resemble each other, at least as nearly as do their habits and external appearance, an account of those of the shadow bird, which are much better known, are given. 


\section{SHADOW BIRDS AND THE HOUSES THEY BUILD.}

WHERE AND HOW THEY BUILD THEM.

The ponds, marshes, rivers, and lakes in southern Africa are sometimes launted by strange, weird creatures called shadow birds, that flit about in the dusk of the evening preying upon frogs, small tish, and water snakes.

At times two or three meeting at the same small pool will silently and solemnly perform a singular dance, skipping absurdly around each other, extending their necks and stiltlike legs, opening and closing their bills, and performing strange antics.

These birds, instead of nests, build themselves great houses of clay and sticks, as much, we are told, as nine feet long by four and a half wide, containing at least a large cart load of sticks, and so strongly built that a heavy, full-grown man can stand on the rounded roof without crushing it. A small door just large enough for the bird to squeeze through is placed at the side most difficult to get at.

These strange dwelling places contain three distinct rooms, the walls of which, like those that form the outside of the house, are carefully built of clay and twigs nicely worked together, and between each of the rooms is a door like that leading outside of these apartments. The one in the rear is the largest, 
and is raised so as to keep dry should heary rains flood other parts of the house, although the entrance is so well macle that this could not often happen. The large back ruom is the hedroom, and actually contains a large, suft bed of dried grusses and leaves.

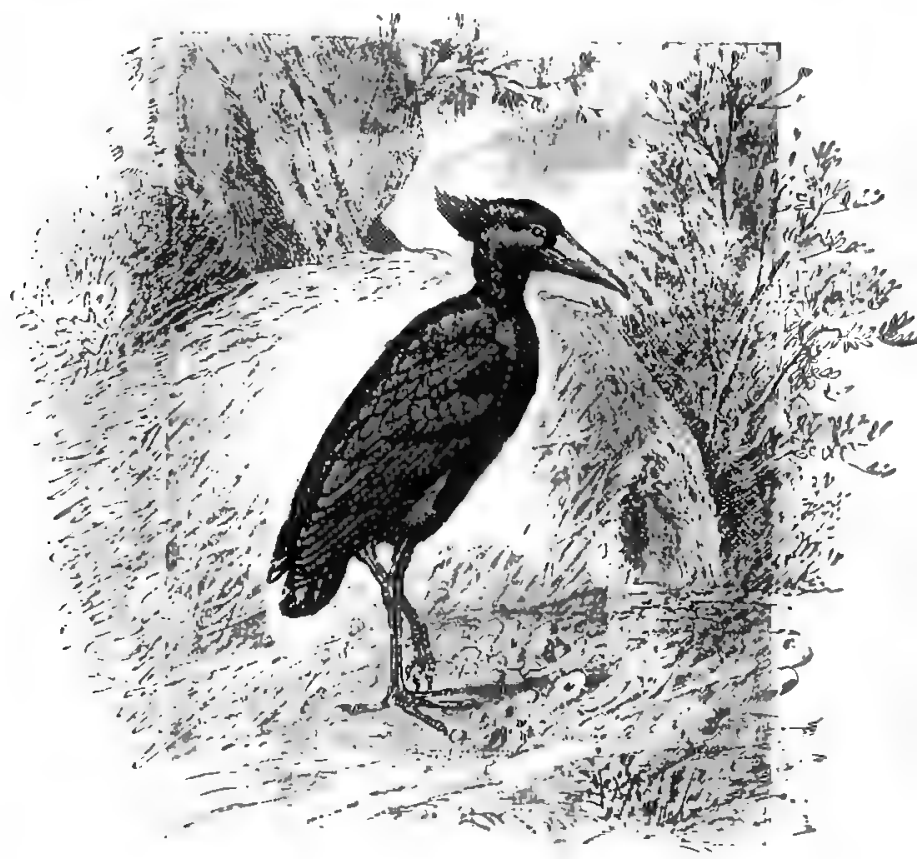

Shalow bird and the house he builds.

Here the esgos are hatched and the young reared by the uniterl pare of both parents. The nestlings are almost naked, very helpless, and grow very slowly, but 
the papa and mamma birds never neglect them, and seem to take pleasure in paying them every loving attention.

The central room is used as a pantry, and contains a goodly supply of provisions; while the small apartment in front serves for a guard room, where the owner, lying flat on the floor with his head thrust out the door, watches sharply for coming danger.

Mr. Layard, in speaking of these birds, says :

"On my late friend Jackson's farm at Nils Port there is a singular rocky glen between two hills. In this spot a beautiful spring, that is never dry, takes its rise. Of course, there are a few wild almond and other trees; indeed, the place is a little oasis amid the barren mountains, and is a favorite resort for hyenas, jackals, leopards, and other wild animals. On the ledges of rocks in this secluded spot a family of shadow birds have for years built their nests. Some of these nests are so placed that it is impossible to get at them, but others can be reached with a little trouble. I counted six or eight within fifty yards, all built in pretty much the same way. About some of them that I visited I found bits of brass, bone buttons, broken crockery, bleached bones, and such things. Mr. Jackson told me that if any of the negroes lost a knife, or any small object belonging to them, that could be easily carried away, on the farm or within some miles of the place, the loser made a point of looking for the missing property among the nests, and was often successful in finding it there." 
The fact is that these birds, like the bower birds of Australia which they so little resemble in size, luoks, or in many of their habits, love to embellish their dwellings with any glittering or bright-colored thing they can pick up.

The strange actions of these birds, and the wonderful skill they show in building their curious homes, serve to protect thein from the savage natives, who indeed are much in awe of them, and dare not hurt them or destroy their dwellings, thinking it very unlucky to do so, for they say "these creatures are not really birds, but spirits, that have the power and will to punish severely any who injure them." It is a curious fact that the natives of Australia have the same fear of injuring the bower bird or its work, and for exactly the same reason.

\section{SPIDERS AND COBWEBS.}

FLYING WITHOUT WINGS.

Exposed to every attack, easily crushed, soft-bodied as they all are, wingless, and in most cases possessing no great speerl in running, or the power-belonging to grasshoppers and their kind-of swiftly springing out of harm's way, spiders, were it not for two gifts bestowed upon them by Nature, could neither defend themselves nor capture the prey upon which they depend for subsistence.

Both of these gifts are fluids, one a poison and 
the other a sort of mucilage, which, being drawn out of the spinnerets of the spider, hardens in contact with the air and becomes the silken thrend that serves the spinner so many useful purposes.

The head of the spider is armed with a pair of sharp pincers or curved fangs, called falces, from a Latin word meaning a sickle. When not in use these are folded back between the rows of teeth; but when the jaws are opened to bite, the falces erect themselves and are thrust into any object that comes between them. Near the point of each of these fangs is a little hole so small as to require a high magnifying power to see it, and this, when the falces are used, gives out a tiny drop of venom, that, minute as it is, makes the wound it enters a fatal one to the insect captured.

Spiders very seldom bite anything besides the insects upon which they feed, but when attacked and unable to escape they open their jaws and try to bite, and if they are large specimens with strong jaws they may succeed in doing so ; "but, notwithstanding the number of stings and pimples that are laid to their charge, undoubted cascs of their biting the human skin are extremely rare," says Professur Packard, who has made them the study of a lifetime, "and the stories of death, insanity, and lameness from spider bites are probably all untrue."

The spinning of webs for the capture of their prey distinguishes spiders from all other living creatures. Not only is the silk of which the web is composed used for constructing nets for the capture of their 
prey, but for lining nests, egg cocoons, bridges-the first suspension bridge in the world was built by a spider-and, most curious of all, for flying machines. Yes, in this, at least; spiders are ahead of mankind; they can fly without the aid of wings or of gas or heated air.

Mr. Packard says: "Small spiders, especially in fine days in autumn, get on the tops of bushes and fences, each apparently anxious to climb as high as possible, and then raise themselves up on tiptoe and turn their bodies up, with their heads toward the wind and spinnerets open. A thread soon blows out from the spinnerets, and, if the current of air continues, spins out to a length of two or three yards, and then offers enough resistance to the wind to carry the spider away with it into the air. As soon as she is clear the spider turns around and grasps the tluread with her feet, and seems to be very contented and comfortable.

"Sometimes they rise rapidly and are soon out of sight, and at other times blow along just ahore the ground."

The silk spun by spiders is much superior to that of silkworns, stronger, firmer, and more elastic, and many attempts have been made to use it; but although gloves and other articles of wearing apparel have been made of spiders' silk, the difficulty of keeping the spiders together in sufficient numbers (each spider has to be separated from the rest, for they fight and devour each other), and the immense latwr inrolved in keeping them supplied with flies or other insects for 


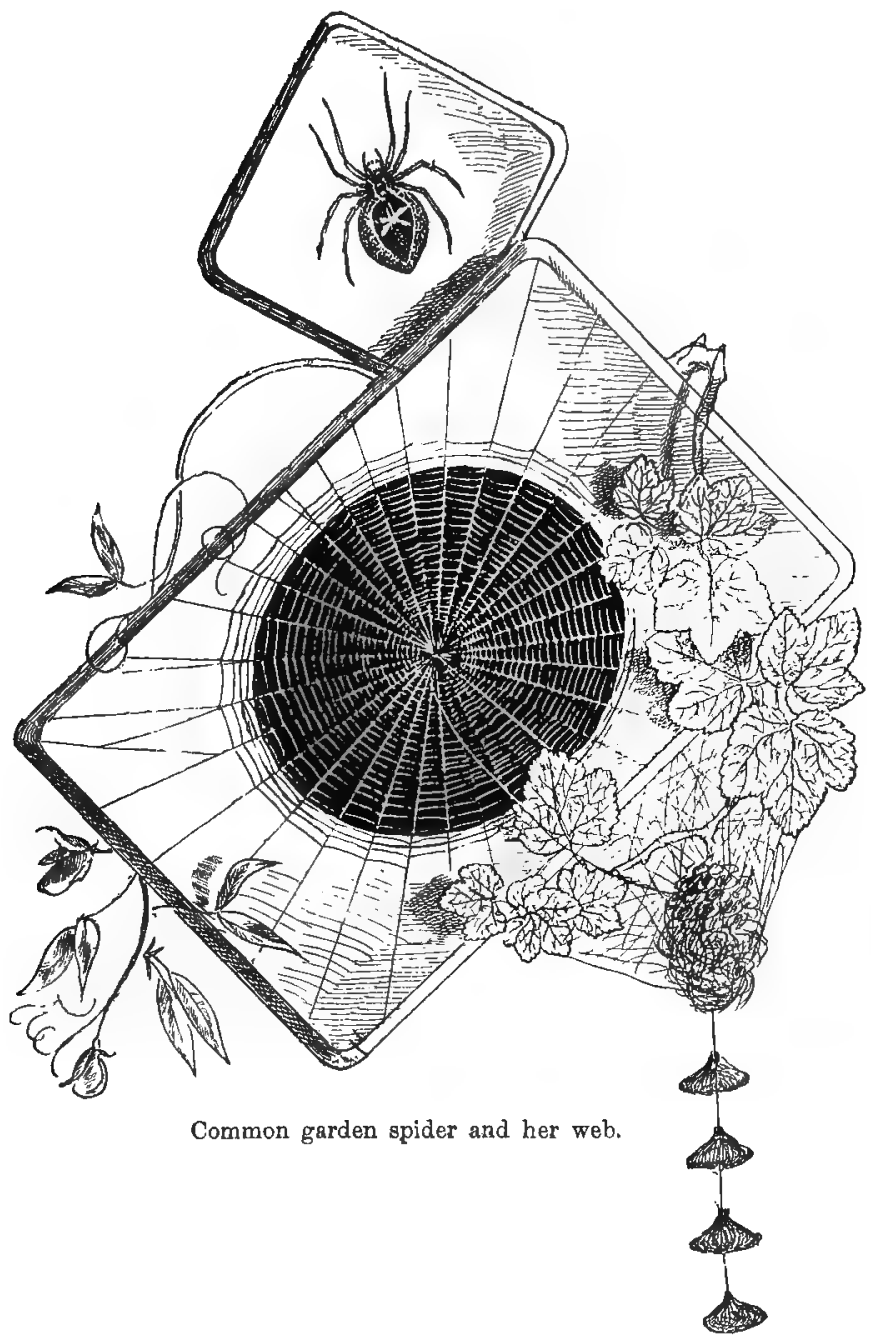


food, have prevented any considerable success in this direction.

When a garden spider is about to construct one of the beautiful nests shown in the illustration, she generally selects a corner of a fence or an open window, or one with a broken pane of glass, or an open space through which flies after the manner of their kind love to dart in and ont. It is also necessary that there should be a crevice or crack near at hand in which, when occasion offers, to take refuge.

The spider begins by attaching a line and carrying it across and fastening it to the opposite side; across the center of the space to be occupied by the web to the middle of this line she attaches another, the other end of which is fastened an inch or so distant from one end of the first line. She then returns and repeats the same movements with a third line, which in its turn is stretched from the common center of the first and second lines to a point as far away from the second thread as that is from the first. And so she proceeds, stopping occasionally in the center to draw her lines taut and fasten them more securely by additional short cross-lines spun here and there, until all the gray lines or rays of her net are completed.

When this is done the spider las a framework that unites strength to elisticity in a remarkable degree, that yields to the slightest pressure and the severest test in proportion to the size of the lines that compose it, and in both cases immediately recovers its position whole and uninjured. 
Upon this framework, beginning at the center, the spider spins a spiral line; the meshes of the net it makes by crossing the radiating, foundation lines, being as far apart as she can reach. Having carried this outward as far as she purposes to have her web extend, the spider commences another between the turns of that first constructed, and of an entirely dif. ferent character, which she carries from the outside to the center of the web.

The first threads spun are dry and smooth, but this last is covered with a sticky fluid to which everything that touches it adheres. Upon these last lines she is careful not to step, but generally has a thread extending from the outside, where she sometimes remains, to the center of her web, always having one foot on the line, which vibrates when anything strikes the net and telegraphs to her the fact that prey is captured.

When this occurs the spider runs to the center of the web, where all the rays meet, touches each in turn to see where the insect is, and, having ascertained this, hastens out and seizes it.

Such webs as the one described require constant repairs; dust and rubbish collect and adhere to the sticky threads, and in time portions of the net become dirty, tangled, and useless. When the spider ascertains this to be the fact she takes out the defective parts and replaces them with new ones, often taking down a whole web and placing a freshly spun net in its place.

The strangest part of this proceeding is, that as 


\section{CURIOUS HOMES AND THEIR TENANTS.}

she goes along gathering up the old web in front and spinning a new one behind her, she rolls the old one into a ball and sits and chews it a long time with evident pleasure.

The spinnerets, which give out the sticky fluid that becomes silken threads on exposure to the air, consist of three pairs of little projections on the hinder part of the body, each beset with a great number of what look like tine hairs or bristles, but which are found under the microscope to be double-jointed tubes ending in fine-drawn points, from each of which escape extremely small drops of a liquid which, being drawn out, dries into delicalte silken lines a thousand times as fine as a hair, which being united together form a thread of from four to eight thousandths of an inch in diameter. It is this that gives spiders' silk such strength; for a cord is strong in proportion to the number of filaments that compose it.

\section{DEATH IN A ROSE.}

THE SPIDER AND THE BUTTERFLY:

Spiders, we know, are in general dingy and dull of hue, grayish black or blackish gray, or brown and dull buff or yellow, witl perhaps more or less obscure markings, but there is a family of these creatures that for a special purpose put on brighter colors. If on looking into the leart of an oxeye daisy, or in a sun flower, perhajs, or upom golden-rod, we 
find a spider of a bright yellow color, it is the Misumeta, Viata, or flower spider.

It is commonly of a bright yellow, perhaps varied with darker markings, but it seems either like 'the chamelion, and much more than the chamelion, to have the power of adapting its color to its surroundings, the petals of the flower it adopts for its nest; or individuals of the same species are very differently colored, and seek flowers to correspond; for whatever blossom serves them for a home matches their hue, be it purple, yellow, white, or pink.

Mrs. Mary Treat, in her little book, My Garden Pets, gives an account of one of these spiders, who, hiding in the heart of a rose, was so nearly the same shade of color as the flower as to make it difficult to distinguish her from the petals of the flower. When the rose faded she moved into another.

Mrs. Treat first saw the spider in July, and lived in the same rose for three weeks, after which she took up her abode in a bright red tea rose whose stamens were more numerous and of a brighter yellow than those of the flowers she had left, and attracted a greater number of insect visitors. She at once went to the center of the rose, but, as if observing the stamens there were of a much deeper yellow than her body, which contrasted with the bright red of the surrounding petals near, now easily seen, she became restless and soon returned to her first lodgings, the color of whose furnishings better matched her complexion.

She spins no web, but depends entirely upon her 
260 CURIOUS HONES AND THEIR TENANTS.

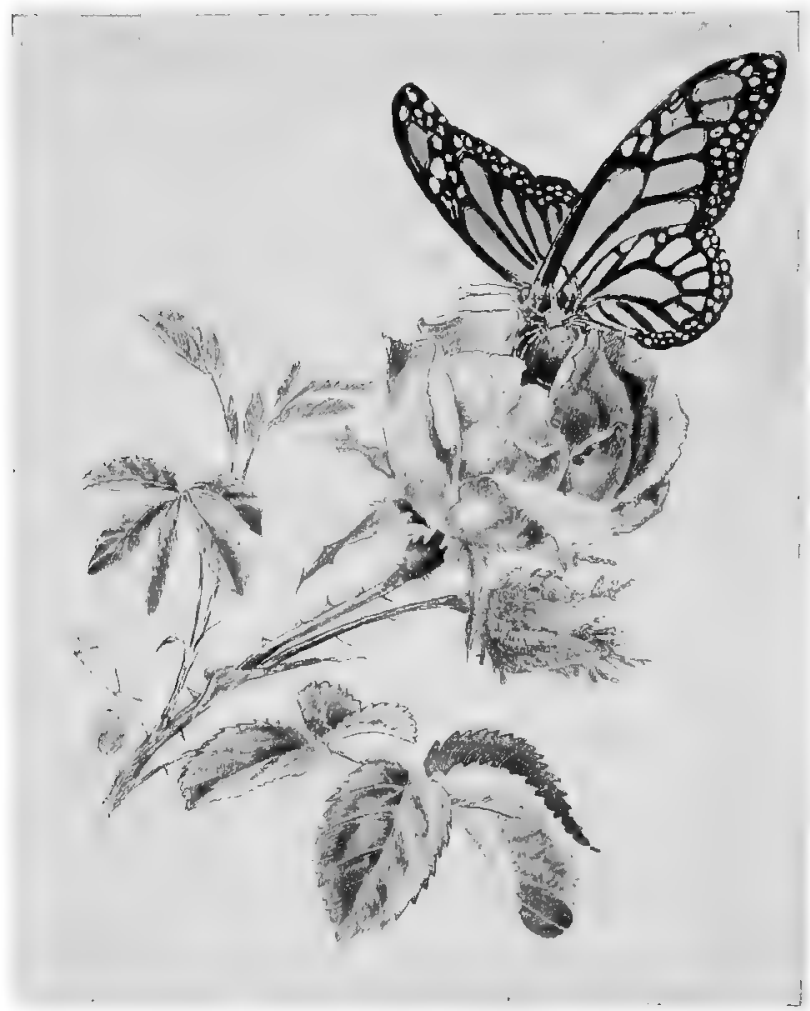

lose spider capturing buttertly.

cunning and bodily strength to take her prey. While waliting to make a capture she crouched in the center of the flower and erected lier long forelegs, so that it was hard to tell thein from the seattering stamens.

If a mail-clad and ferocious, warriorlike wasp 
or a big, stalwart bumblebee called on her, down dropped her stamenlike legs, still more closely clung her yellow body to the yellow center of the flower, and she pretended not to be at home, and not until such objectionable visitors departed did she resume her former attitude.

Now, however, a pretty lady butterfly, all unconscious of harm, rests a moment on the flower. Misumeta does not stir. She knows her business too well for that, until Miss Butterfly, on the lookout, perhaps, for a sip of dew or a taste of honey, comes within her reach, then out fly the lean arms of the yellow hag in a fatal embrace about the body of the unfortunate insect, which, though four or five times her own weight, she prevents from rising into the air until her poisoned fangs have done their work, and the butterfly will visit no more flowers.

\section{INSECT HOME-BUILDERS AND THEIR TOOLS.}

I.

To the proper study of Nature one has only to look about in country lanes and fields and forests. The galleries of the Creator are to be found everywhere except where those of man exist. And what exquisite workmanship do they not exhibit! A devout old man (Basil, an ante-Nicene father of the Church) who lived in the third century has said:

"If you speak of the organism of an insect, what 
you say will be in some sort a demonstration of His power whose hand formed it, for the skill of the craftsman is exhibited more in the minuteness and delicacy of his workmanship than in the size of what he makes. He who stretched out the infinite firmament, and hollowed the bel of the sea, pierced the ting sting of the bee for the ejection of its poison."

The astronomer who looks up toward the unfathomable depths of space with the aid of his costly instruments sees no more of creation than is to be found in a patch of living, velvety moss at the foot of a forest tree. In such humble and obscure localities exist little families, communities, and nations that carry on the business of life in their own queer fashion, which nevertheless affords many parallels to human life and man's way of doing things. Like us, these pygmy peoples have their governments, their wars, their children, and their homes to look after; they have servants, household pets, and police; they are cattle-raisers, farmers, hunters, and fishers, and practice all the handicrafts of men.

Take, for example, the paper-makers. While the rest of mankind were writing imperishable thoughts on all sorts of clumsy makeshifts, the pith of reeds, cut spirally and flattened by pressure, leather, the leaves of palm trees, wood, stone, clay, and what not, the Chjnese painted their tiresome treatises on paper; but even they did not first invent paper. Long before they discovered how to make it the wasp was manufacturing a firm ancl durable article of this valuable substance, "by very much the same process," says 
Mr. James Rennie, "as that by which human hands now manufacture it with the best aid of chemistry and machinery."

Not only do these insects make paper, but also cardboard, and, anticipating the Japanese, build their habitations of papier maché. One species of wasp in South America, of whose curious nest an illustration is given, manufactures a cardboard of so firm a texture and so smooth a surface that it can be written, drawn, or painted upon like the best Bristol board; and in one respect at least it is superior to the manmade article, for it is entirely waterproof. The heaviest showers fail to soften it or dampen the interior of the nest it incases.

II.

CARPENTERS.

The carpenters find many representatives, beside the carpenter ants described in a previous chapter, among the insect tribes. An English insect related to our bumblebee, but differing in color, being of a dark violet tint, well deserves her name of carpenter bee. Selecting a suitable locality, a stump, post, or any bit of timber-if a little softened by decay so much the better-she proceeds to excavate her ten- or twelvestoried house with more ease than a human workman aided by every appliance with which modern science can supply him can tunnel into the hillside.

First entering the timber in a horizontal direction, she abruptly turns and extends the passage downward 


\section{CURIOUS IIOMES AND TIIEIR TENANTS.}
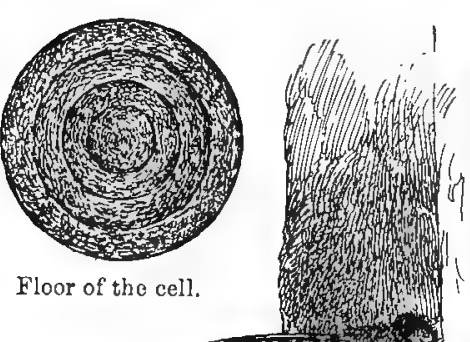

Floor of the cell.
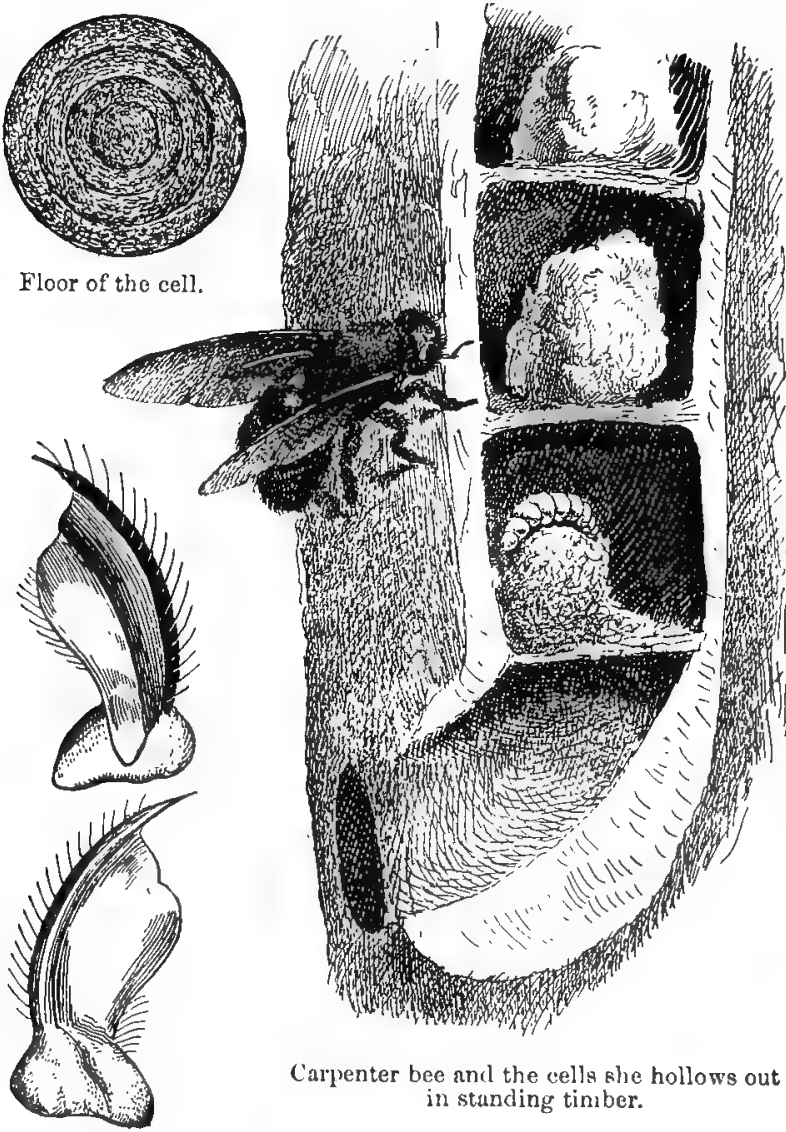

7
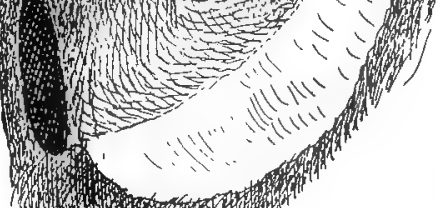

S 1 in 10 ,

thing

Carpenter bee and the cells she hollows out in standing timber.

Chisels of the curponter bec, much enlarged. 
at a right angle to that by which she entered. Twelve times her own length she hollows out her tunnel (as if a man with his proportionally greater size and strength should cut his way some sixty odd or seventy odd feet into solid timber), and then she prepares to put in floors and furnish the chambers into which her tunnel is thus divided.

She has been very careful to preserve her "chips"; no sawdust or shavings obstruct or litter her work, which is clean cut and perfect. All the results of her gnawings are gathered into a compact heap near by and preserved for future use.

An observer says: "She proceeds thus: At the bottom of her excavation she deposits an egg, and over it fills a space nearly an inch high with pollen of flowers made into a paste with honey. She covers this over with a ceiling composed of cemented sawdust taken from what she has saved. This also serves for a floor to the next chamber above it. She lays this floor by cementing around the wall a ring of wood chip3, and within this ring forms another, and so on until she has constructed a circular plate about the thickness of a ten-cent piece. She proceeds in the same manner until she has completed ten or twelve cells, when she builds up the main entrance with a barrier of similar materials."

From the bottom cell a back entrance affords egress to the firstborn and first adult bee, and Réaumur also noticed a door opening from the middle cell. The young bees readily eat through the floors, but can not penetrate the solid wood. The implements 
with which the violet carpenter bee works are chisels - here shown-hard and keen edged, and most practical tools, however seemingly inadequate for the work they do.

But while the carpenter bees work with chisels, there are many insects that use saws. These saws, however, are much

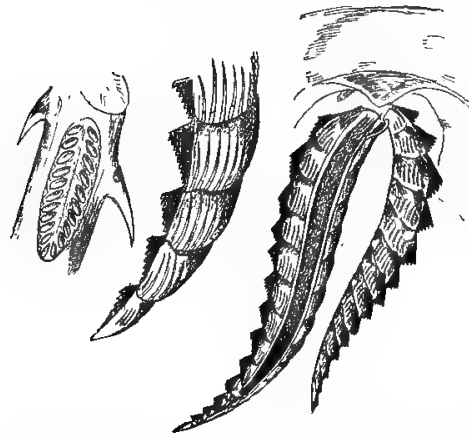

Saws of the saw Hly, much enlarged. better contrived, finished, and sharpened, and more effective than any yet made of steel. With them the little craftsmen undertake jobs of work which, if multiplied proportionately to his size, no human workman would think of entering upon unaided. In the saw fly, which owns perhaps the most perfect instruments of the kind, our inventors might find a teacher whose suggestions would not be valueless. The saw is in the head of the insect. It is double, working alternately in the groove, the two very cleverly strengthened by a thick plate of horn at their back. The system of toothing is different from any used by hmman beings, and the saw itself, instead of having the teeth in a straight line, is curved into the shape of the $f$ hole in a violin. Like the wonderfully effective cutting edge of sharks' teeth, the teeth of the insect's saw are fumished with 
smaller teeth, and the sides of the saw itself as well as its edge are supplied with teeth. It is, in fact, a rasp and saw combined. It not only cuts a groove, but it smooths the sawed surfaces and keeps the kerf open.

Mr. Gosse, as quoted by the Rev. J. G. Wood, points out that, beautiful and elaborate as these instruments are, they are but the sheaths of a still finer and more delicate pair of saws. These secondary saws have only a few teeth on the edge, and these near the point; whereas the sides are furnished with a number of razor-sharp blades, set on their edges, slightly overlapping each other and directed backward. In Nature's Teachings there is a notice of several large beetles, called sawyer beetles, which actually answer the purpose of circular saws. Seizing a branch with their deeply toothed jaws, they fly around and around it until it is sawed in two. They have been known to saw off a branch larger than an ordinary walking stick.

III.

VARNISHERS AND UPHOLSTERERS.

No observant lover of Nature can have failed to notice how the buds of the horse-chestnut and other trees are coated with a natural waterproof varnish, a lacquer that not only protects them from injury but adds materially to their appearance.

There are times, while this varnish is yet soft and fresh, when the buds and twigs from which it exudes 
may be seen swarming with bees, all busy in collecting it for their own uses. Long before mankind had arrived at what may be called the varnish period, when the surfaces of furniture and utensils began to receive coats of viscous material not for the purpose of coloring but to make them look polished and brilliant, the bees were expert varnishers.

Among hive-bees, wax is used with the utmost economy, for its collection and elaboration are attended with so much labor that only the hive-bee takes the trouble to store it in any quantity, other species supplying its place with inferior substitutes. The partitions of wax that separate the marvelous structure of the honeycomb into cells-so arranged as to combine the greatest amount of available storeroom with the minimum of material-are so extremely thin that the insect finds it necessary to strengthen their edges with accumulations of this bee varnish, or propolis, as it is called. The comb is fastened to its support, and all crevices are filled with this material. The propolis can be easily distinguished from the wax by its darker color and natural luster.

Among the insect upholsterers re have the leafcutting bees. It is said that a French gardener, finding their extraordinary nests in his flower beds, conld not account for the presence of such skillfully contrived curios otherwise than that they were placed there by some evilly disposed magician to work him or his garden harm, and with this idea showed them to his employer, who with some difficulty persuaded lim that they were the work of insects. 
INSECT HOME-BUILDERS AND THEIR 'IOOLS. 269

In a cylindrical hole excavated in a well-beaten and hardened pathway several thimble-shaped cells

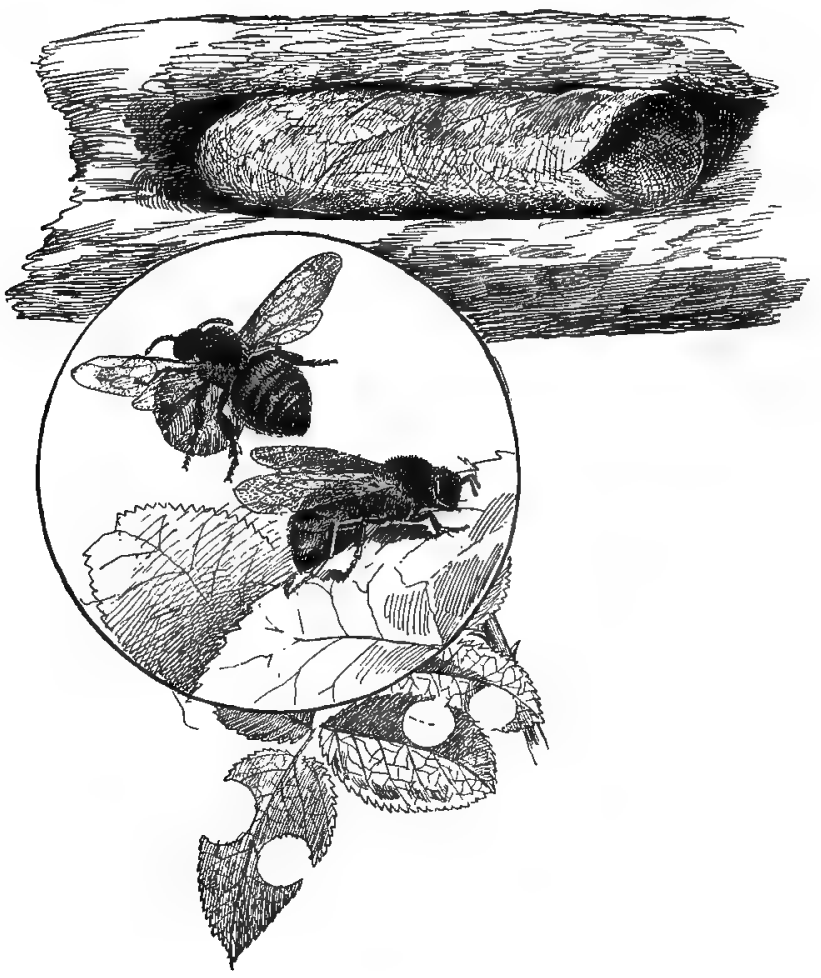

Leaf-cutting bees and nest.

are constructed, made of leaf cuttings very artificially and skillfully worked and folded into shape, and inserted the bottom of one into the mouth of another. When one cell is completed and stored with a rose- 
colored conserve of the honey and pollen of the thistle upon which is deposited a single egg, it is covered with three layers of leaf cutting so exactly circular that, as observers notice, no compass could define their margin more accurately.

IV.

MINERS AND GRAVE DIGGERS.

The miners and excavators are best represented by the mole cricket. Like the mammal after which it is named, this little creature digs extensive galleries. The structure of its fore limbs and feet much resembles that of the mole. The tibix of these limbs are broad, flat, and of a strong, horny substance, and are armed with sharp, strong claws.

Nothing more unlike the ordinary forelegs of an insect could well have been contrived. If the edges of our spades were similarly armed their efficiency would be undoubtedly increased. The whole structure of the insect is in all parts adapted to the work it has to perform.

The breast is defended by a cuirass of strong horn, backed by double layers of tough gristle, in front of which are firmly jointed the shoulder blades, to prevent the insect from being wounded by the powerful impact of earth and sand in digging.

Passing over, for want of space, many most interesting branches of industry practiced by insects, we close appropriately with the sextons, or grave-diggers, whose craft is the last that can be used for the benefit 
of their fellows. The insects, however, do not confine their offices to other insects, for if they find the dead body of any small animal or bird, sereral unite in their efforts, get beneath it and dig with great energy, shoving aside with their hind legs the dirt

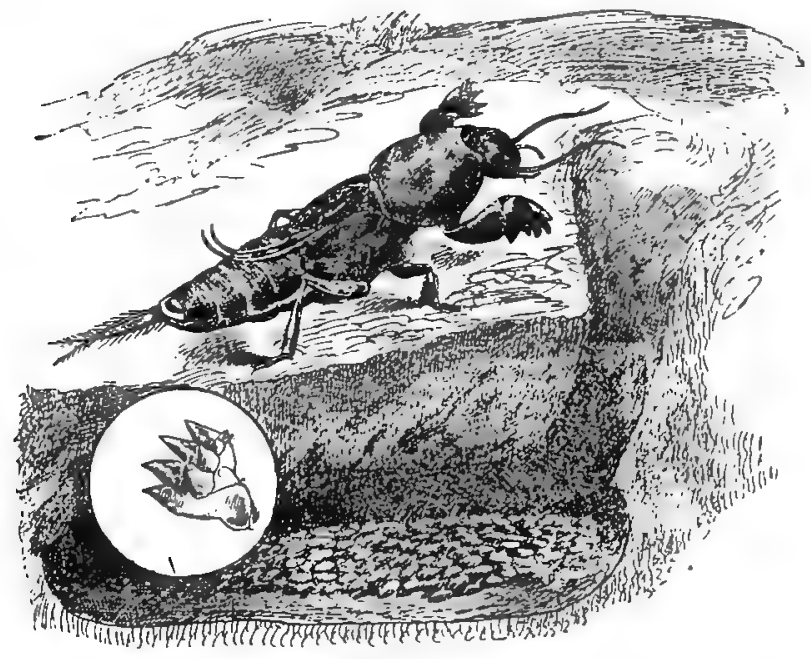

Mole cricket and her nest.

they excavate, without pausing, until the body gradually sinks below the level of the surrounding earth.

When it has sunken low enough to serve their purposes, having first deposited their eggs in the body, they throw over it the earth they have excavated, carefully leveling and smoothing the ground above the grave.

In conclusion, it may be said that the habits and 


\section{CURIOUS HOMES AND THEIR TENANTS.}

life of American insects afford an immense and fruitful field to the investigator. With no more expensive appliances than a magnifying glass and a cheap pocket microscope, but with eyes to see, patience to investigate, and brains to be interested in and comprehend what is seen and investigated, any one who has sufficient leisure and love for Nature may make discoveries that will cause his name to be known throughout the civilized world. Indeed, I doubt if there exists a more promising field for scientific investigation than the open-air study of American insects. 


\section{N D E X.}

Aard-Vark, 29.

Alactaga, 46.

Ameba, 4.

Andrena bee, 63, 64 .

A nest in a waterfall, 210.

Anhimia, 228.

Animal rolled into a ball, 206.

Animals that sleep througb the winter, 108.

Ant-eater, 27.

Ant-eater porcupine, 41.

Antennarius and nest, 186.

Ant-milking aphides, 52 .

Ants, agricultural, $77,79$.

Ants at home, 74 .

Australian cliff-dwellers, 94.

$\begin{array}{ll}\text { “ } & \text { duckbill, } 39 . \\ \text { “ } & \text { native houses, } 15 . \\ \text { sea-horse, } 3 .\end{array}$

Bank burrowers, 36.

Bashful Billy, 113.

Baya bird, 121, 122.

Bees as miners, 62 .

Bird burrower, puffin, 53.

Birds, tenement-house, 117.

Birds that make edible nests, 18.

Bumblebee and nest, 68 .

Butterfly house, 147.

Butterfly that mimics a leaf, 148.

Caddice flies, 193.

Carpenters, 262.
Carpenter ants, 82.

"6 bee and cells, 263.

Carysfort lighthouse, 10.

Cheirogale, 161.

Choropus, nest and young, 160 .

City of birds, 236.

Cliff-d wellings, 88.

Cliff-dwellings, situntion, 92 .

Communal dwellings and those who inhabit them, 1.

Coon bear, long-tailed, 115.

Coral development, 13.

" field, 10.

" living, 12.

" polyps, 12.

" polyp open and closed, 12.

Cow blackbird, 188.

Cretaceous or Chalk period, 6 .

Crossbill, 126.

Cteniza, 59.

Cuckoo bees, 63.

Death in a rose, 258.

Diamond birds and nests, 50,51 .

Dogs, prairie, 32.

Dogs that are not dogs, 32 .

Dome beneath the waters, 189 .

Dwellings in skcletons of whales, 232.

Eagles' nests, 97.

Echidna, 42.

Eseulent swallow, 18. 


\section{CURIOUS HOMES AND THEIR TENANTS.}

Extinct animals hunted by man, 17.

Feathcred gardeners, 243.

“ parson, 134.

" seanstress, 133.

Fellow with pockets in his eheeks, 47.

Fisherman's dwelling, New Guinea, 104.

Fish, web-spinning, 185.

Floating nest, 181.

Flowereater and nest, 131.

Four-footed lake-dwellers, 177.

Fun-loving kagus, 246.

Gopher and nest, 48.

Grasstish, 14.

Head-footed nest-builder, 200 .

Hercules destroying fabled liydra, 206.

Hermit crab in mass of polyps, 222 .

Flermit crab with sea anemone on its back, 221 .

Hog, ground, 2 ?

Home in a horn, 234.

Home of American water thrush, 211.

Ilome of the mole, 24.

Homes of Eskimo, 117.

Honey ants and their homes, 84.

Ilornbill, 140.

House that wears a hat, $209,231$.

Humau care-dwellers, 15.

" clitf-dwellers, $\uparrow$.

"nest-builders, 154, 155.

Jyclin, 205.

IIydroids, 11.

Indians on coast of North Americal, 1 .

Infusorial, 7.
Inscet home-builders and their tools, 260 .

[s] and-builders, 8.

Jerboas, 45.

Jerboas and jumping mice, 43.

Kangaroo's nest, 157.

Kinkajou, long-tailed, 115.

Lake-dwellers, human, 173.

Lake-dwellers, four-footel, 1 t 7 .

Lake-dwellings on Lake IIaracaybo, 174, 177 .

Leaf-cutting bees and nest, 268 .

Lima, 1 y7.

Little yuudrupeds that lay eggs, 39.

Loris, 114.

Malmags, 105.

Miners and grave-diggers, 269.

Mole, 21 ; home of, 24 ; burlows of, 25 ; eyes and ears of, 26.

Mole cricket and her nest, 270 .

Mintu, American jumping. 44.

Mouse, uest of field, 163 .

Nest in a waterfall, 210.

Nest of pirs's feet, 160 .

Octopus, 200.

(1) tonpus at rest, 203.

Old penguin and nestling, 237.

Penguin running, 239.

P'holus, 198.

Planula, 13.

Porcupinc ant-eaters, 41.

Portable houses, 215.

Portable house of hermit crais, 219.

Potoroo, 158.

Potto, 110. 
Prairie dogs, 33.

Pueblo Indians, 1.

"6 ornament, 89.

" plan of building, 90 .

Putfin, 53, 54.

Puny races inhabiting America, 2.

Quarrelsome little nest-builders, 187.

Queer little kangaroo's nest, 157 .

Queer-looking ground hog, 24.

Rock-hopper penguin, 236.

Rase-Leaf bee, 65 .

Salangene, 19.

Saw of the saw fly, 265 .

Scoletus, 144, 145 .

Sea fans, 11.

"squirt, 8.

" urchins imbedded in rock, $20 \%$.

Senses of ants, 68 .

Shadow birds and the house they build, 250.

Shells that build nests, $196,197$.

Snow house of Eskimo, 168.

" " " of polar berr, 169 .

" " of seal, 168.

Spider, turret-building, 56,57 .

Spiders and cobwebs, 252.

Spiders and nest, 255.

Sponges, 11.
Stealing a home, 138.

Stickleback, 188.

Stickleback and nest, 188.

strange animal, 105.

Swallow breeding places and nests

of esculent swallows in northern Borneo, 14.

Tailor bird and nest, 133.

Tarsius spectrum, 107.

Tenement house built by birds, 117.

Thrush, water, 211.

Tree bouses, 101, 102.

Tube dwellings, 193.

Tube dwellings of serpulæ, 194.

Turret-building spider, 56,57 .

Turcoman's portable dwellinge, 216 .

Varnishers and upholsterers, 266.

Walking-stick insects, 146 .

Walled up, $\mathrm{I} 40$.

Waru house, 223, 225.

Wasps as miners, 62 .

Wasps' nest in a spool, 67 .

Wasps' nests, 149.

Wasps' nests, South American, 151.

Web-spinning fish, 185.

Wood-eater, 144.

Work versus play, 71.

World-builders, 4 . 



\section{APPLETON AND COMPANY'S PUBLICATIONS.}

\section{APPLETONS' HOME-READING BOOKS.}

\section{Eḍited by W. T. HARRIS, A. M., LL. D.,}

U. S. Commissioner of Education.

NOW READY.

7 THE STORY OF THE BIRDS. By James NewTON BASKETT. 65 cents net.

7 HE PLANT WORLD: Its Romances and Realities. Compiled and edited by Frank Vincent, M. A., author of "Actual Africa," etc. 60 cents net.

THE STORY OF OLIVER TWIST. By ChARLES Dickens. Condensed for home and school reading by ElLA BOYCE KIRK. 60 cents net.

IN BROOK AND BAYOU; or, Life in the Still Waters. By Clara Kern Bayliss, 60 cents net.

CURIOUS HOMES AND THEIR TENANTS. By James Carter Beard. 65 cents net.

THE HALL OF SHELLS. By Mrs. A. S. Hardy, author of "Three Singers," etc. 60 cents net.

UNCLE SAM'S SECRETS. By O. P. Austin. 75 cents net.

JAROLD'S FIRST DISCOVERIES. By J. W. Trokger, A. M., B. S. Volume I in Nature-Study Readers. 25 cents net.

UNCLE ROBERT'S VISIT. By FRANCIS W. PARKER and NeLLIE L. HrLm. Volume III in Uncle Robert's Geographies, edited by Francis W. Parker. 50 cents net.

CRUSOE'S ISLAND. A Bird-Hunter's Story. By FRFDERICK A. Ober, author of "Camps in the Caribbees," "Travels in Mexico," etc. 65 cents net.

IN PRESS.

NATURE-STUDY READERS. 4 vols. Edited by J. W. TROEGER. NEWS FROM THE BIRDS. BY LEANDER S. KEYSER.

UNCLE ROBERT'S GEOGRAPHIES. Edited by FRANCIS W. PARKER. ON THE FARM. By NeLlie L. HeLM and Francts W. PARKEr.

(Others in preparation.)

D. APPLETON AND COMPANY, NEW YORK. 


\section{APPLETON AND COMPANY'S PUBLICATIONS.}

GOOD BOOKS FOR YOUNG READERS.

\section{HE EXPLOTTS OF MYLES STANDISH. By
HENRY JoHnson (Muirhead Robertson), author of "From Scrooby to Plymouth Rock," etc. Illustrated. I2mo. Cloth, $\$ 1.50$.}

"A vivid picture, keen and penetrating in its interests, and familianzing young penple in a popular way with the hardships endured by the early settlers of New England." - Boston Herald.

"All that concerns the settlement at New Plymouth is told with fine skill and vividness of description. . A book that must he read from cover to cover with unfaltering interest." - Bosion Saturday Evening Gazette.

CHRISTINE'S CAREER. A Story for Girls. By Pauline King. Illustrated. I2mo. Cloth, specially bound, \$I.5O.

The story is fresh and modern, relieved by inciderits and constant humor, and the Jessons which are suggested are most beneficial.

YOHN BOYD'S ADVENTURES. Bу TномAS W. KNox, author of "The Boy Travelers," etc. With 12 fullpage Illustrations. I2mo. Cloth, \$1.50.

ALONG THE FLORIDA REEF. By Charles F. HOLDER, joint author of "Elements of Zoölogy." w'ith numerous Illustrations. I2mo. Cloth, \$1.5O.

ENGLISHMAN'S HAI'EN. By W. J. GordON, author of "The Captain-General," etc. With 8 full-page Illustrations. I2mo. Cluth, \$r.5o.

TJE ALL. A Story of Outdoor Life and Adventure in Arkansas. By Octave Thanet. With i 2 full-page Illustrations by E. J. Austen and Others. 12mo. Cloth, \$1.50.

KING TOM AND THE RUNAWAYS. By Louis Pendleton. The experiences of two boys in the forests of Georgia. With 6 Illustrations by E. W. Kemble. I2mo. Cloth, \$I. 50 .

D. APPLETON AND COMPANY. NEW YORK. 


\section{APPLETON AND COMPANY'S PUBLICATIONS.}

BOOKS BY HEZEKIAH BUT'LERWORTH.

UNIFORM EDITION. EACH, IIMO, CLOTH, \$1.5O.

\section{TRUE TO HIS HOME. A Tale of the Boyhood of Franklin. Illustrated by $\mathrm{H}$. Winthrop Peirce.}

"No book can be placed in the hands of the youth of the country which is better calculated to develop within them the spirit of indusiry, enterprise, molality, patriotism, and charity than this record of the boyhood of America's greatest sage." - The Indeperdent.

\section{THE WAMPUM BELT; or, The Fairest Page of History. A Tale of William Penn's Treaty with the Indians. With 6 full-page Illustrations.}

"The personality and character of Willam Penn are most admirably treated, and his figure looms up to its noble proportions in the historic perspectsve." - Fhiladelp/ica Press.

THE KNIGHT OF LIBERTY. A Tale of the Fortunes of Lafayette. With 6 full-page Illustrations.

"No better reading for the young man can be imagined than tris fascinating narrative."-Boston Traveler.

$7 H E$ PATRIOT SCHOOLMASTER. A Tale of
the Minutemen and the Sons of Liberty. With 6 full-page Illustrations by $\mathrm{H}$. Winthrop Peirce.

"Can be recommended as a terse, stirring, and admirable story, and it thr bs throughout with the best spirit of Americanism." -Nezv Y'ark Matl and Express. T THE BOYHOOD OF LINCOLN. A Story of
the Black Hawk War and the Tunker Schoolmaster. With i2 Illustrations and colored Frontispiece. Budget.

"One of the best stories for youlhful readers that has ever been written." Boston THE BOYS OF GREENWAY COURT. A Story
of the Early Years of Washington. With to full-page Illustrations.

" The book is replete with picturesque incidents and legends of hunting exploits and adventures, and the figure of young Washington is shown in a light which will be sure to enlist the interest of young readers."-Chicago Herald.

THE LOG SCHOOL-HOUSE ON THE CO-
LUMBIA. Beard, E. J. Austen, and Others.

"This book will charm all who turn its pages. There are few books of popular information concerning the pioneers of the great Northwest, and this one is worthy of sincere praise."-Seattle Post-Intelligencer.

\section{APPLETON AND COMPANV, NEW YORK.}




\section{APPLETON AND COMPANY'S PUBLICATIONS.}

THE LIBRARY OF USEFUL STORIES.

Each book complete in itself. By writers of authority in their various spheres. I6mo. Cloth, 40 cents per volume.

NOW READY.

THE STORY OF THE STARS. By G. F. Chambers, F. R. A.S., author of "Handbook of Descriptive and Practical Astronomy," etc. With 24 Illustrations.

THE STORY OF "PRIMITIVE" MAN. By EDWARD ClODd, author of "The Story of Creation," etc.

THE STORT OF THE PLANTS. By GRANT ALlen, author of "Flowers and their Pedigrees," etc.

THE STORY OF THE EARTH. By H. G. SEELEY, F. R. S., Professor of Geography in King's College, London. With Illustrations.

THE STORY OF THE SOLAR SYSTEM. By G. F. Chambers, F. R. A.S.

THE STORY OF A PIECE OF COAL. By E. A. Martin, F. G.S. HE STORY OF ELECTRICITY. By John
Munro, C.E.

7 HE STORY OF EXTINCT CIVILIZATIONS OF THE EAST. By ROBERT ANDERSON, M. A., F. A.S., author of "Early England," "The Stuart Period," etc.

THE STORY OF THE EARTH'S ATMOSPHERE. By Douglas Archibald, Fellow and Sometime - Vice-President of the Royal Meteorological Society, London.

7 HE STORY OF GERM LIFE. BY H. W. Conn, Professor of Biology, Wesleyan University; Author of "The Living World," etc.

D. APPLETON AND COMPANY, NEW YORK. 







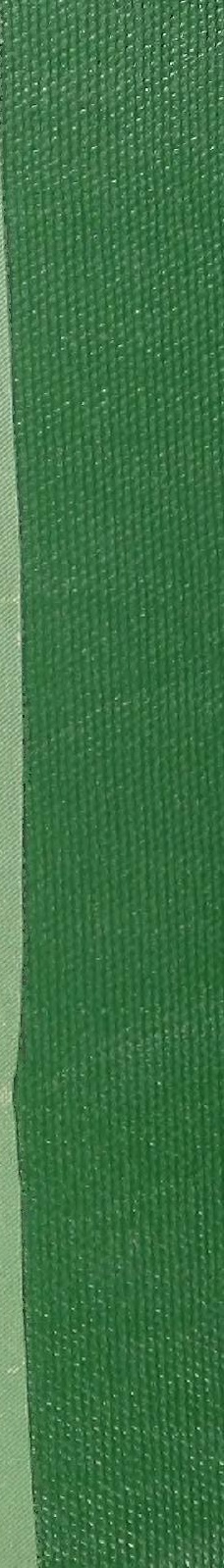

